\title{
Commercial Nuclear Fuel from U.S. and Russian Surplus Defense Inventories: Materials, Policies, and Market Effects
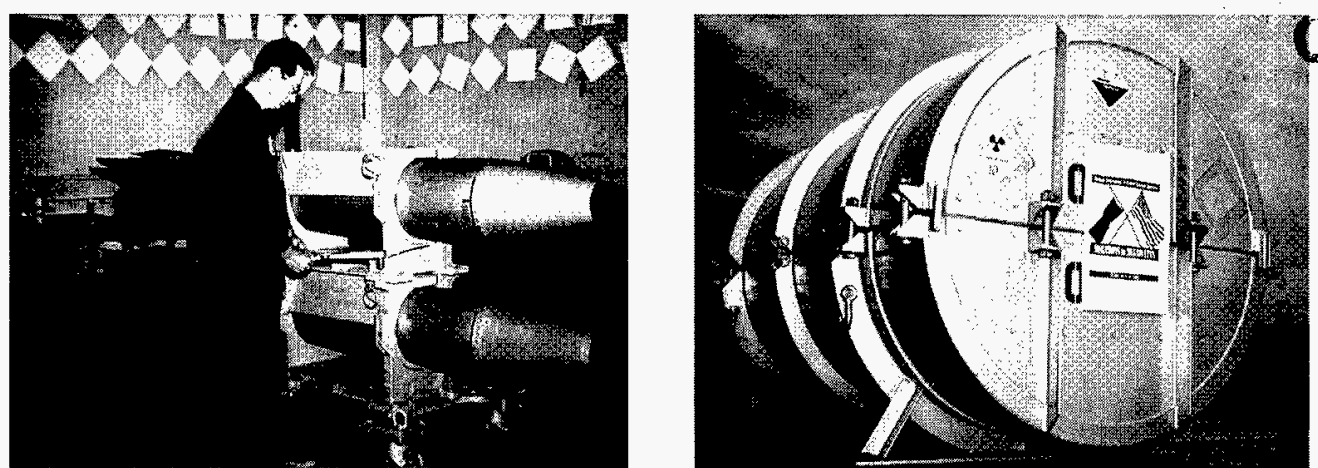
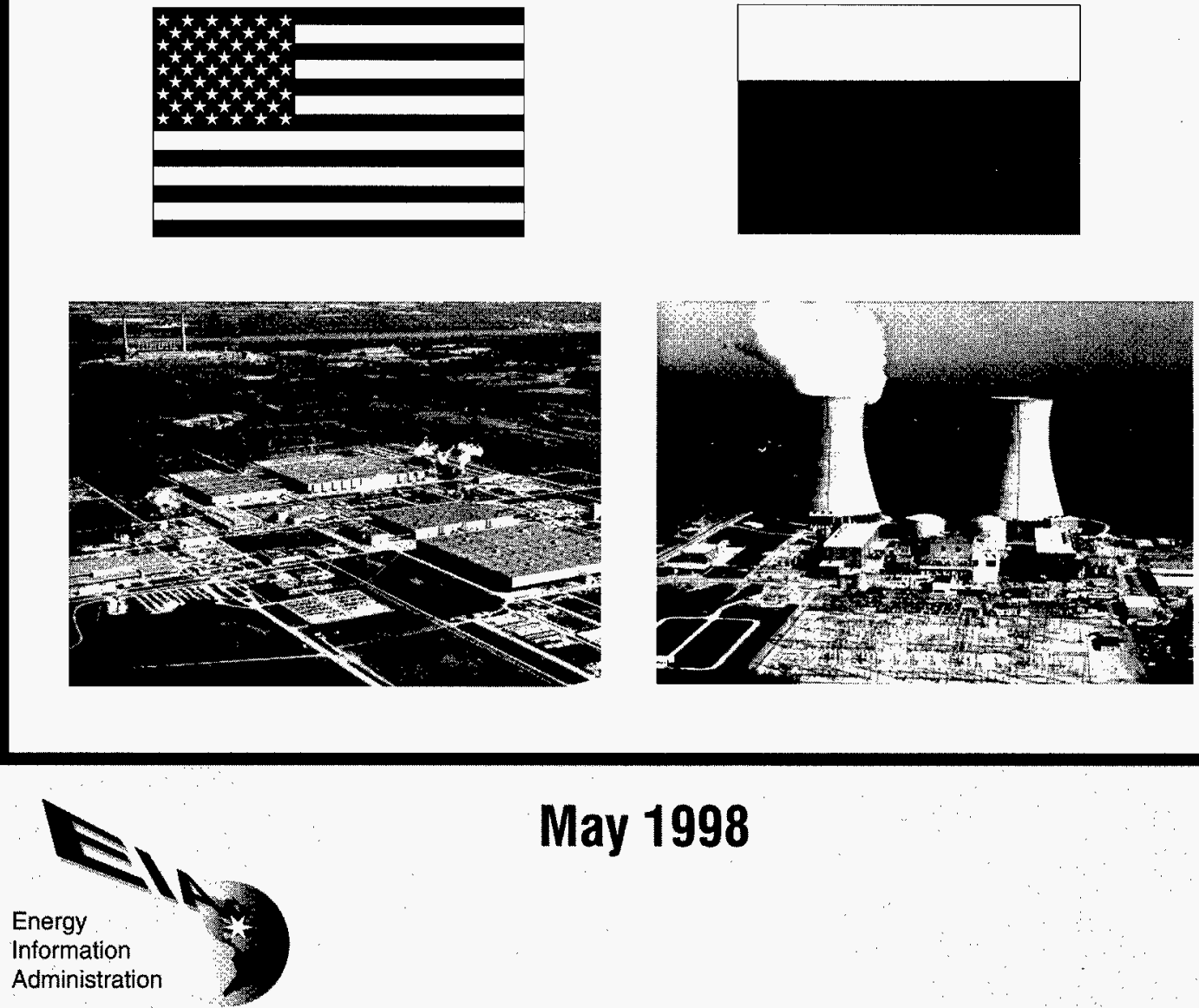

May 1998 


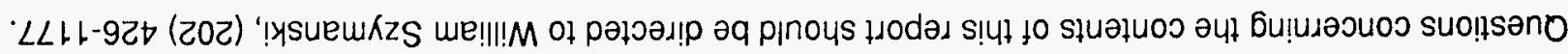

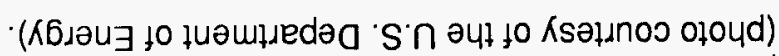

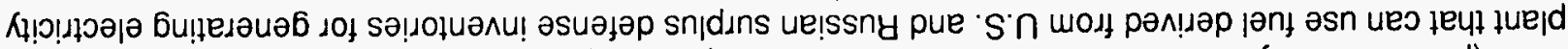

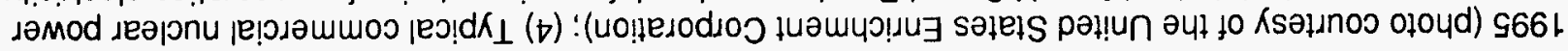

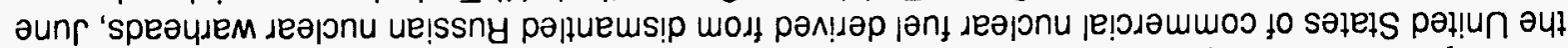

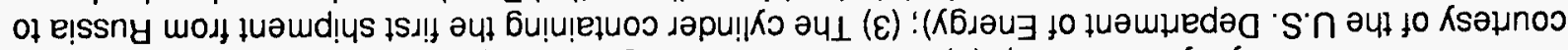

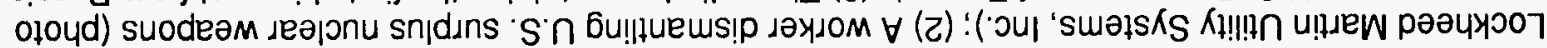

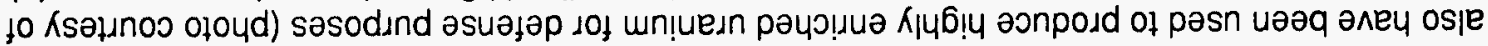

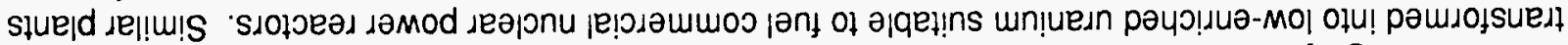

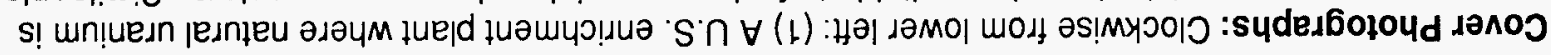

$$
\begin{aligned}
& \text { (xej) } \angle t 58-12 \varepsilon(\varepsilon 0 L) \div \text { LV89- } 2 S S(008)-1 \\
& \text { peoy jefoy hod } 582 \varsigma
\end{aligned}
$$

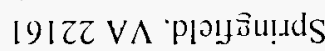

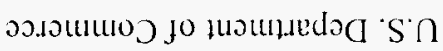

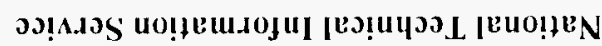

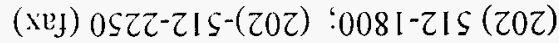

$$
\begin{aligned}
& \text { tS6L-0SZSI Vd 'ys.mqsh!d } \\
& \nabla S 6 I L E \times \operatorname{xog}^{\circ} \mathrm{O} \mathrm{d}
\end{aligned}
$$

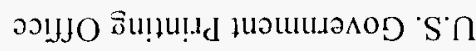

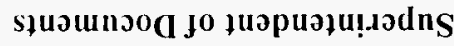

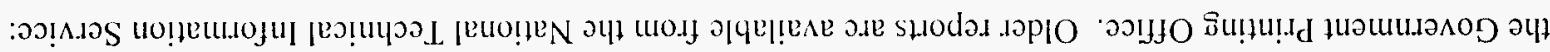

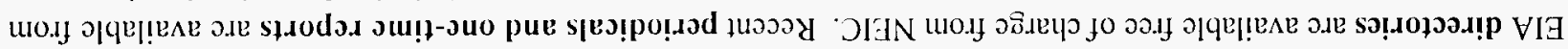

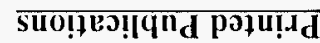

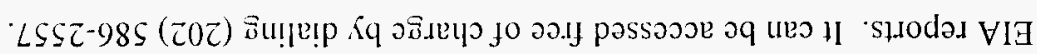

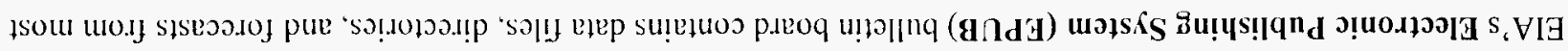

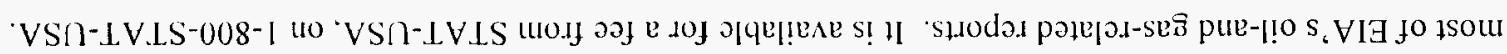

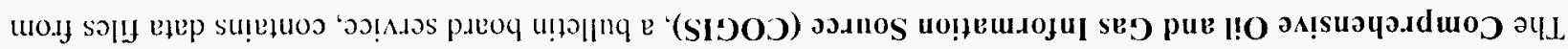

' $\mathrm{SS} \cap-\mathrm{L} H L \mathrm{LS}-008-\mathrm{I}$

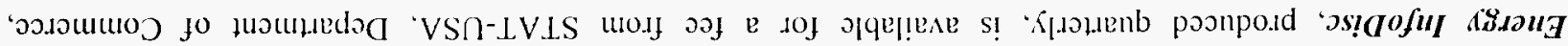

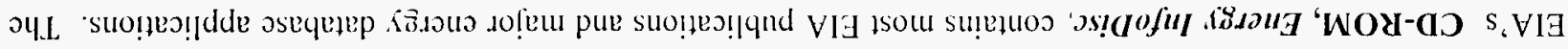

วग!ฺ qวM

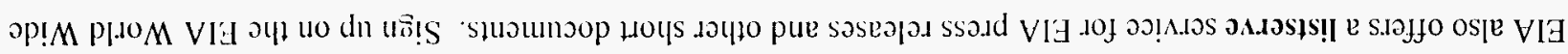

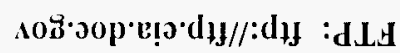

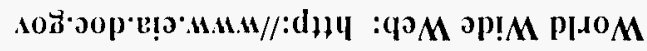

'səo!nı⿰丿s pue słonposd

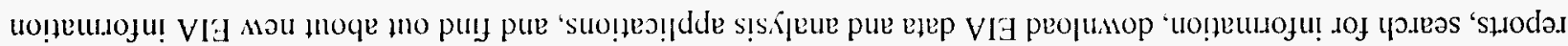

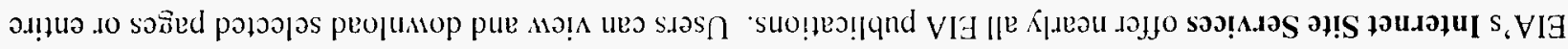

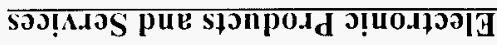

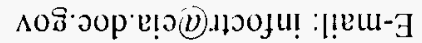

$1811-985(20 z):$ X.L.L

(xej) $L 2 \angle 0^{-9} 98 \varsigma(\tau 0 \tau)$ $0088-985(\tau 0 z)$
ธ8S0Z DO 'น01ธิU!บSEM

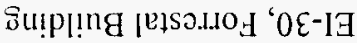

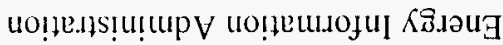

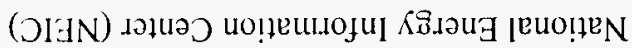

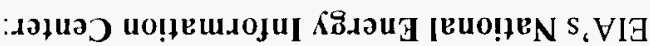

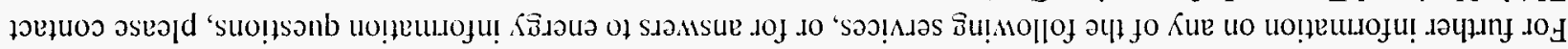




\section{DISCLAIMER}

This report was prepared as an account of work sponsored by an agency of the United States Government. Neither the United States Government nor any agency thereof, nor any of their employees, makes any warranty, express or implied, or assumes any legal liability or responsibility for the accuracy, completeness, or usefulness of any information, apparatus, product, or process disclosed, or represents that its use would not infringe privately owned rights. Reference herein to any specific commercial product, process, or service by trade name, trademark, manufacturer, or otherwise does not necessarily constitute or imply its endorsement, recommendation, or favoring by the United States Government or any agency thereof. The views and opinions of authors expressed herein do not necessarily state or reflect those of the United States Government or any agency thereof. 
DOE/EIA-0619

Distribution Category UC-950

\section{Commercial Nuclear Fuel from U.S. and Russian Surplus Defense Inventories: Materials, Policies, and Market Effects}

May 1998

DISTRIBUTION OF THS DCOUMENT IS UNLIMTTED
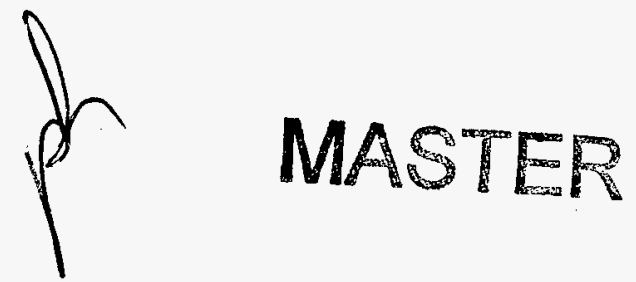

Energy Information Administration

Office of Coal, Nuclear, Electric and Alternate Fuels

U.S. Department of Energy

Washington, DC 20585

This report was prepared by the Energy Information Administration, the independent statistical and analytical agency within the Department of Energy. The information contained herein should not be construed as advocating or reflecting any policy position of the Department of Energy or of any other organization. 


\section{Contacts}

This report was prepared in the Office of Coal, Nuclear, Electric and Alternate Fuels by the Analysis and Systems Division. General information regarding this publication may be obtained from the National Energy Information Center (202/586-8800); or Dr. Z.D. Nikodem
(202/426-1179), Chief of the Nuclear Fuel Cycle Branch. Technical information about this report may be obtained from William Szymanski (202/426-1177 or Internet: william.szymanski@eia.doe.gov), project manager and principal author. 


\section{Preface}

Section 205(a)(2) of the Department of Energy Organization Act of 1977 (Public Law 95-91) requires the Administrator of the Energy Information Administration (EIA) to carry out a central, comprehensive, and unified energy data information program that will collect, evaluate, assemble, analyze, and disseminate data and information on energy resources, reserves, production, demand, technology, and related economic and statistical information. To meet these responsibilities in the area of nuclear power, EIA has prepared this report entitled Commercial Nuclear Fuel from U.S. and Russian Surplus Defense Inventories: Materials, Policies, and Market Effects.

The legislation that created the EIA vested the organization with an element of statutory independence. The EIA does not take positions on policy questions. Its responsibilities are to provide timely, high-quality information and to perform objective, credible analyses in support of deliberations by both public and private decisionmakers. Accordingly, this report does not purport to represent the policy position of the U.S. Department of Energy or the Administration. This report should be of particular interest to Congress, Federal regulators and policymakers, nuclear fuel suppliers, utilities, policy and financial analysts, and trade associations.

The purpose of this report is to analyze the effects on the commercial nuclear fuel market that would likely result from current plans to sell U.S. and Russian government surplus inventories. Although governments, especially in Russia, are substantially involved in civilian nuclear power programs, this report considers only uranium and plutonium that were produced and stockpiled for defense purposes and subsequently declared as surplus. Because current plans to commercialize U.S. and Russian surplus defense inventories are expected to displace principally uranium supplies, conversion, and enrichment from traditional sources; only those stages of the fuel cycle are considered in this report; however, the analysis is focused on the uranium market.

The first five chapters of the report provide information of the materials and policies that comprise U.S. and Russian Government plans for commercializing surplus nuclear materials. A brief historical perspective on the evolution of government policies making it possible to convert nuclear materials stockpiled for military purposes to peaceful uses is presented in Chapter 1 . Chapter 2 provides a description of the military and civilian nuclear fuel cycles in order to give the reader background information about the similarities between the two cycles. These similarities allow for the conversion of surplus defense inventories to commercial nuclear fuel for producing electricity. An overview of the inventories built up by the United States and Russia is presented in Chapter 3. Descriptions of the activities related to the conversion of Russian highly enriched uranium (HEU) from dismantled weapons to nuclear fuel are provided in Chapter 4. A detailed chronology of the commercialization of Russian HEU is presented in Appendix A. U.S. plans for commercializing uranium and plutonium are presented in Chapter 5. For commercialization efforts by the U.S. Government, detailed chronologies for both the overall activities and the required regulatory procedures are provided in Appendices $B$ and $C$, respectively.

The last two chapters focus on the market effects of current government commercialization plans. An assessment of the key market penetration issues that could influence the availability of surplus defense inventories is provided in Chapter 6 . Chapter 7 provides an analysis of the effects of U.S. and Russian government inventories based on different scenarios of market penetration. As part of the analysis, three cases developed with ELA's Uranium Market Model are presented to simulate the effects on spot-market prices and world uranium production. A detailed description of the UMM is provided in Appendix D. Also, Chapter 7 contains an estimate of savings that could be realized by U.S. nuclear power generating companies as a result of access to competitively priced uranium from surplus defense inventories.

The projections presented in this report represent expectations of what could occur given a set of assumptions. Many of these assumptions are based on government policies or historical demand and supply relationships, which are subject to dynamic change. Because nuclear nonproliferation and other political objectives are important determinants, the commercialization of U.S. and Russian surplus defense inventories cannot be explained solely in economic terms. In addition, official information is not uniformly available for all the market participants. Given the uncertainty inherent in forecasting, it is important that the projections presented in this report be viewed in the proper context of the assumptions. 


\section{Contents}

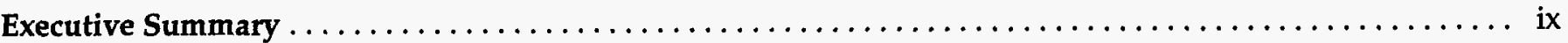

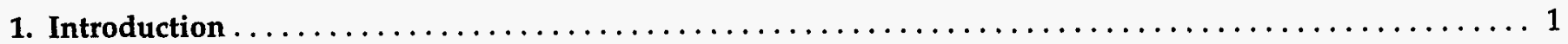

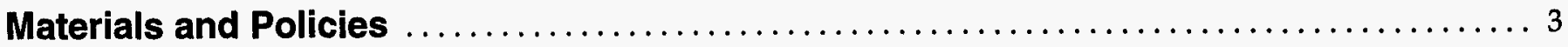

2. Relationship Between Military and Civilian Nuclear Programs $\ldots \ldots \ldots \ldots \ldots \ldots \ldots \ldots \ldots \ldots \ldots \ldots$

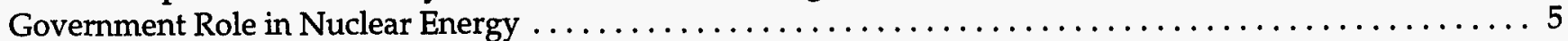

Relationship Between the Civilian and Military Nuclear Fuel Cycles $\ldots \ldots \ldots \ldots \ldots \ldots \ldots \ldots \ldots \ldots \ldots 5$

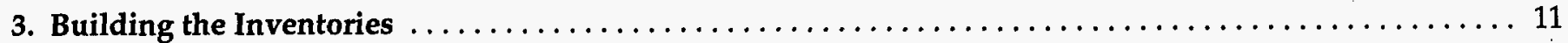

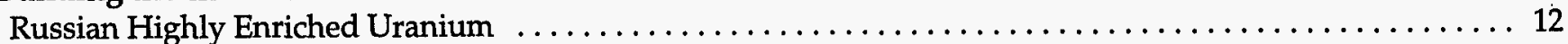

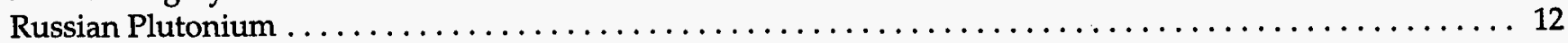

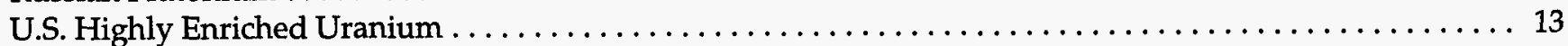

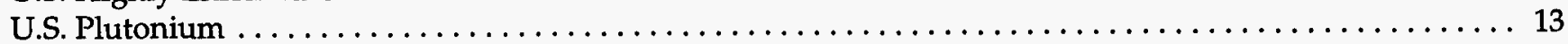

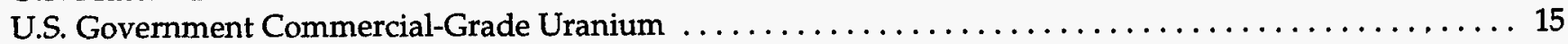

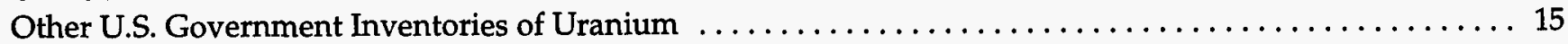

4. Sale of Highly Enriched Uranium from Dismantled Russian Nuclear Weapons $\ldots \ldots \ldots \ldots \ldots \ldots \ldots$

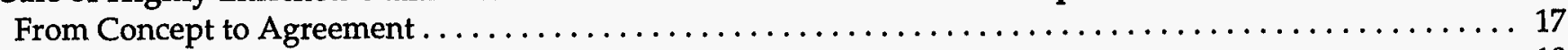

Delays in Implementing the Russian HEU Agreement $\ldots \ldots \ldots \ldots \ldots \ldots \ldots \ldots \ldots \ldots \ldots \ldots \ldots \ldots \ldots$

First Deliveries of Low-Enriched Uranium Derived from Russian HEU . . . . . . . . . . . . . . . 19

Authorization for the Sale of the Russian Uranium Feed Component $\ldots \ldots \ldots \ldots \ldots \ldots \ldots \ldots \ldots \ldots$

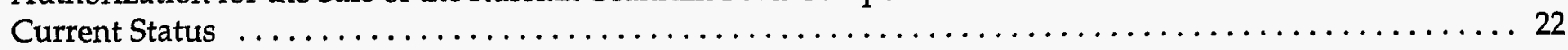

5. Commercialization of U.S. Government Surplus Inventories $\ldots \ldots \ldots \ldots \ldots \ldots \ldots \ldots \ldots \ldots \ldots \ldots \ldots$

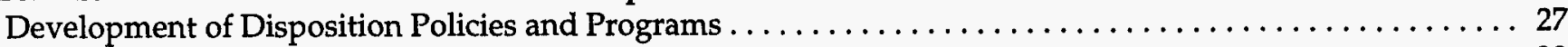

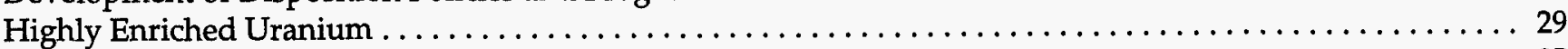

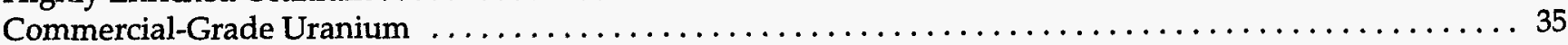

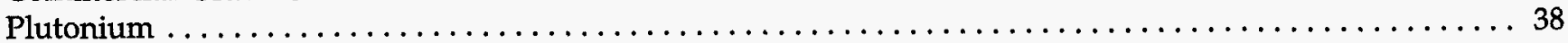

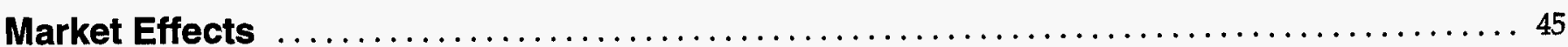

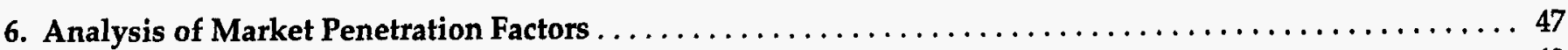

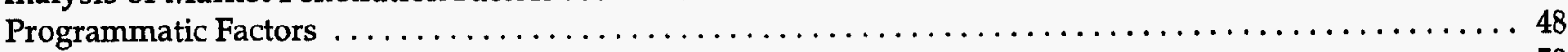

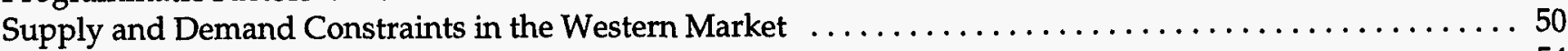

Availability of Russian Feed for Western Consumption $\ldots \ldots \ldots \ldots \ldots \ldots \ldots \ldots \ldots \ldots \ldots \ldots \ldots$

7. The Effects of Selling Government Surplus Defense Inventories $\ldots \ldots \ldots \ldots \ldots \ldots \ldots \ldots \ldots \ldots \ldots \ldots$

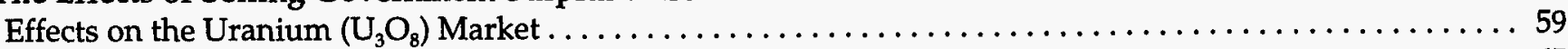

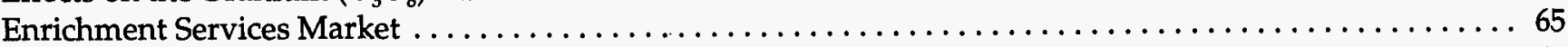

Enriched Uranium Product . . . . . . . . . . . . . . . . . . . . . . . . . . . . . . . . . 69

Projected Uranium Cost Savings to Nuclear Power Generating Companies $\ldots \ldots \ldots \ldots \ldots \ldots \ldots \ldots \ldots \ldots$

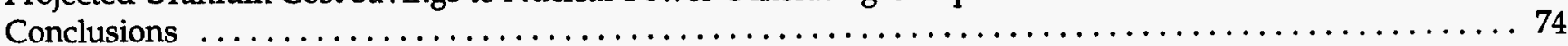




\section{Contents (continued)}

Appendices

Page

A. Chronology of the Commercialization of Russian Highly Enriched Uranium, 1991-1997 . . . . . . . . 79

B. Key Milestones in the Disposition of U.S. Government Surplus Highly Enriched Uranium, Commercial-Grade Uranium, and Plutonium, 1992-1997

C. Principal Documents Prepared by the U.S. Department of Energy for the Storage and/or Disposition of U.S. Government Surplus Highly Enriched Uranium, Plutonium, Natural Uranium, and Low-Enriched Uranium in Accordance with the National Environmental Policy Act,

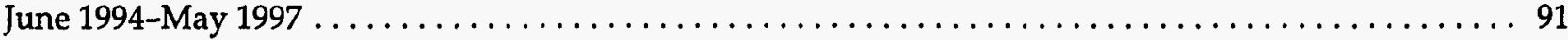

D. Description of Uranium Market Model $\ldots \ldots \ldots \ldots \ldots \ldots \ldots \ldots \ldots \ldots \ldots \ldots \ldots \ldots \ldots \ldots . \ldots 5$

E. U.S. Customary Units of Measurement, International System of Units (SI), and Selected Tables and Figures in SI Metric Units $\ldots \ldots \ldots \ldots \ldots \ldots \ldots \ldots \ldots \ldots \ldots \ldots \ldots \ldots \ldots \ldots \ldots$

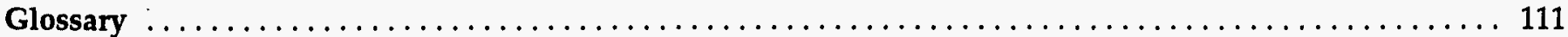


1. U.S. and Russian Surplus Defense Inventories Considered in This Report $\ldots \ldots \ldots \ldots \ldots \ldots \ldots \ldots 2$

2. Commercial Nuclear Fuel Markets $\ldots \ldots \ldots \ldots \ldots \ldots \ldots \ldots \ldots \ldots \ldots \ldots \ldots \ldots \ldots \ldots \ldots$

3. U.S. and Russian Production and Inventories of Highly Enriched Uranium (HEU) and Plutonium for

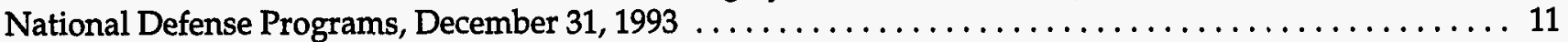

4. U.S. Restrictions on Selling the Uranium Feed Component of Low-Enriched Uranium (LEU) Produced from Blending Down Russian Highly Enriched Uranium (HEU) After January 1, $1997 \ldots \ldots \ldots \ldots \ldots .21$

5. Characterization of Inventory in Relation to the U.S. Department of Energy's Disposition Program for Surplus Weapons-Usable Highly Enriched Uranium (HEU), as of February 28, $1998 \ldots \ldots \ldots \ldots \ldots \ldots$

6. Equivalent Natural Uranium Feed and SWU Components of Low-Enriched Uranium (LEU) Derived from U.S. Highly Enriched Uranium (HEU) Based on the U.S. Department of Energy's Plans to Transfer Surplus HEU to the United States Enrichment Corporation (USEC) and the Tennessee Valley Authority (TVA) ... 33

7. Status of U.S. Department of Energy (DOE) Plans to Dispose of Surplus Commercial-Grade Natural Uranium and Low-Enriched Uranium (LEU), as of December 31, $1997 \ldots \ldots \ldots \ldots \ldots \ldots \ldots \ldots \ldots$

8. U.S. Department of Energy's (DOE) Schedule for Implementing the Reactor Alternative to Dispose of

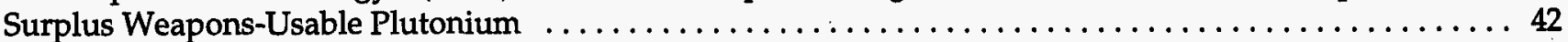

9. Potential Commercial Availability of U.S. and Russian Surplus Defense Inventories, 1997-2010, Based on Schedules Contained in Government Disposition Plans as of March 31, $1997 \ldots \ldots \ldots \ldots \ldots 60$

10. Assumed Market Penetration of U.S. and Russian Surplus Defense Inventories in the Uranium

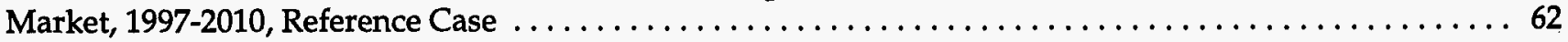

11. Assumed Market Penetration of U.S. and Russian Surplus Defense Inventories in the Uranium Market, $1997-2010$, Lower HEU Feed Case . . . . . . . . . . . . . . . . . . . . . . . . . . 64

12. Assumed Market Penetration of U.S. and Russian Surplus Defense Inventories in the Uranium

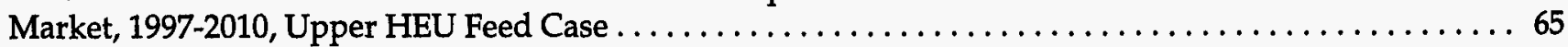

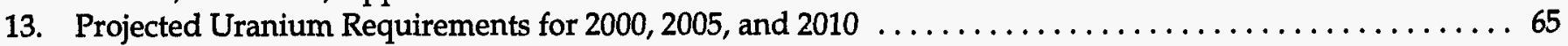

14. Projected Supply for Western Reactor Requirements in the Lower HEU Feed Case, 2000, 2005, and 2010 . 66

15. Estimates of Potential Cumulative Savings in Uranium Procurement Costs for U.S. Nuclear Power Generating Companies from the Assumed Market Penetration of U.S. and Russian Surplus Defense Inventories Based on Different Assumptions About Uranium Supply, 1997-2010 . . . . . . . . . . . 74

A1. Chronology of the Commercialization of Russian HEU, $1991-1997 \ldots \ldots \ldots \ldots \ldots \ldots \ldots \ldots \ldots \ldots$

B1. Key Milestones in the Disposition of U.S. Government Surplus Highly Enriched Uranium (HEU), Commercial-Grade Uranium, and Plutonium, $1992-1997 \ldots \ldots \ldots \ldots \ldots \ldots \ldots \ldots \ldots \ldots \ldots . \ldots \ldots$

C1. Principal Documents Prepared by the U.S. Department of Energy for the Storage and/or Disposition of U.S. Government Surplus Highly Enriched Uranium (HEU), Plutonium, Natural Uranium, and Low-Enriched Uranium (LEU) in Accordance with the National Environmental Policy Act,

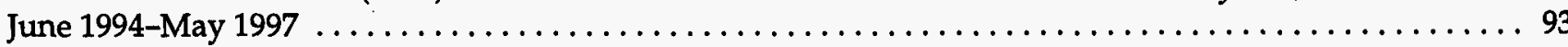

E1. U.S. Restrictions on Selling the Uranium Feed Component of Low-Enriched Uranium (LEU) Produced from Blending Down Russian Highly Enriched Uranium (HEU) After January 1, 1997 . . . . . . . . . . 102

E2. Equivalent Natural Uranium Feed and SWU Components of Low-Enriched Uranium (LEU) Derived from U.S. Highly Enriched Uranium (HEU) Based on the U.S. Department of Energy's Plans to Transfer Surplus HEU to the United States Enrichment Corporation (USEC) and the Tennessee Valley

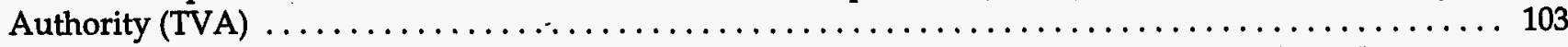

E3. Status of the U.S. Department of Energy's (DOE) Plans to Dispose of Surplus Commercial-Grade Natural Uranium and Low-Enriched Uranium (LEU), as of October 31, $1997 \ldots \ldots \ldots \ldots \ldots \ldots \ldots$

E4. Potential Commercial Availability of U.S. and Russian Surplus Defense Inventories, 1997-2010, Based on Schedules Contained in Government Disposition Plans as of March 31, 1997 . . . . . . . . . 105

E5. Assumed Market Penetration of U.S. and Russian Surplus Defense Inventories in the Uranium Market, 1997-2010, Reference Case . . . . . . . . . . . . . . . . . . . . . . . . . . . 106

E6. Assumed Market Penetration of U.S. and Russian Surplus Defense Inventories in the Uranium

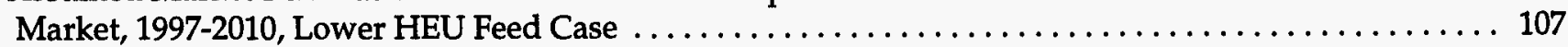

E7. Assumed Market Penetration of U.S. and Russian Surplus Defense Inventories in the Uranium

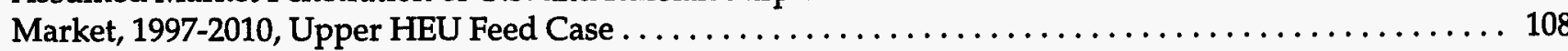


E8. Projected Uranium Requirements for 2000, 2005, and $2010 \ldots \ldots \ldots \ldots \ldots \ldots \ldots \ldots \ldots \ldots \ldots \ldots$

E9. Projected Supply for Western Reactor Requirements for Lower HEU Feed Case, 2000, 2005, and 2010 . . 109

\section{Figures}

1. Relationship of Military and Civilian Nuclear Fuel Cycle $\ldots \ldots \ldots \ldots \ldots \ldots \ldots \ldots \ldots \ldots \ldots \ldots$

2. Comparison Between the Original and Current Schedules for Blending Down Highly Enriched Uranium (HEU) from Dismantled Russian Nuclear Weapons Pursuant to the Russian HEU Agreement,

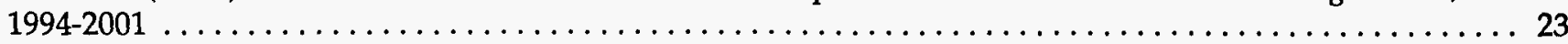

3. Relationship of the U.S. Department of Energy's (DOE) Surplus Highly Enriched Uranium (HEU) Disposition Program and the Civilian Nuclear Fuel Cycle $\ldots \ldots \ldots \ldots \ldots \ldots \ldots \ldots \ldots \ldots \ldots \ldots \ldots$

4. Relationship of the U.S. Department of Energy's Surplus Plutonium Disposition Alternatives and the

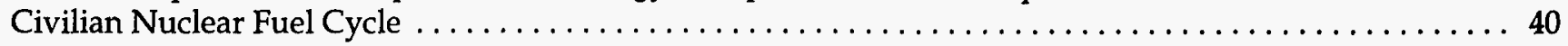

5. Comparison of the Uranium Reserves of Major Mining Projects and the Uranium Contained in U.S. and Russian Surplus Defense Inventories Currently Scheduled for Commercialization . . . . . . . . 47

6. Potential Market Availability of Uranium Derived from U.S. and Russian Surplus Defense Inventories Currently Scheduled for Commercialization, $1997-2010 \ldots \ldots \ldots \ldots \ldots \ldots \ldots \ldots \ldots \ldots \ldots \ldots$

7. Potential Market Availability of Enrichment Derived from U.S. and Russian Surplus Defense Inventories Currently Scheduled for Commercialization, $1997-2010 \ldots \ldots \ldots \ldots \ldots \ldots \ldots \ldots \ldots \ldots 48$

8. Potential Availability of Uranium Feed from the Blending Down of Russian Highly Enriched Uranium

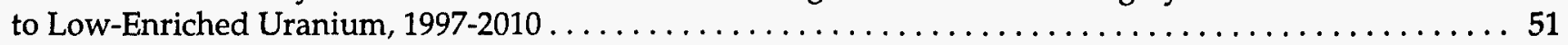

9. Anticipated Uranium Market Requirements of U.S. Utilities, 1997-2006, as of December 31, 1996 . . . ... 52

10. Quota for Deliveries to U.S. End Users of Uranium Feed from the Blending Down of Russian Highly Enriched Uranium to Low-Enriched Uranium as a Share of Projected U.S. Uranium Requirements,

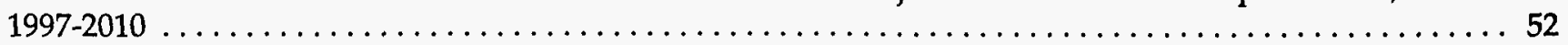

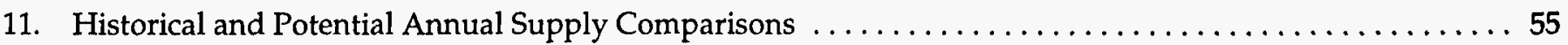

12. Potential Sources of Supply to Fill Russian Requirements-Reference Scenario, 1997-2010 . . . . . . . . 56

13. Potential Sources of Supply to Fill Russian Requirements-Mine Closure Scenario, 1997-2010 . . . . . .. 57

14. Potential Cumulative Drawdown of Russian Commercial Inventories, $1997-2010 \ldots \ldots \ldots \ldots \ldots \ldots . . .57$

15. Comparison of Planned Commercial Availability of Uranium Derived from U.S. and Russian Surplus Defense Inventories and Market Penetration Assumed for EIA Reference Case, 1997-2010 . . . . . 61

16. Assumed Market Penetration of Uranium Derived from U.S. and Russian Surplus Defense

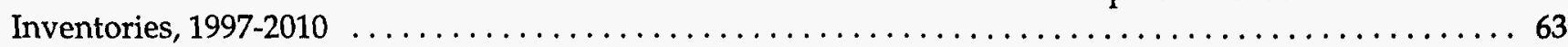

17. Production Capability Versus Price for U.S. Uranium Production Centers $\ldots \ldots \ldots \ldots \ldots \ldots \ldots \ldots \ldots 6$

18. Projected Spot-Market Prices in the Restricted U.S. Uranium Market, $1997-2010 \ldots \ldots \ldots \ldots \ldots \ldots .667$

19. Worldwide Enrichment Supply Capability Under Different Capacity Assumptions, No Surplus

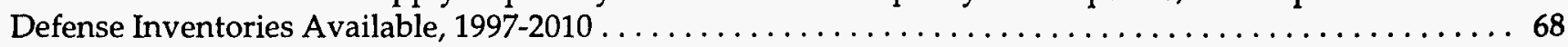

20. Worldwide Enrichment Supply Capability Under Different Capacity Assumptions, Availability of Surplus Defense Inventories Based on Uranium Reference Case, 1997-2010 . . . . . . . . . . . . . 69

21. Average Price of U.S.- and Foreign-Origin Uranium Delivered to U.S. Utilities from Domestic Suppliers

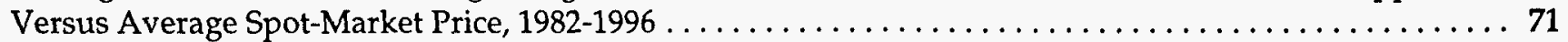

22. Results of Regression Analysis of the Relationship Between Contract Prices and Spot-Market Price,

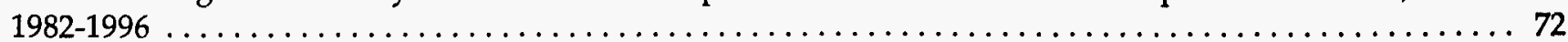

23. Incremental Rise in Projected Uranium Spot-Market Price: Three No Surplus Defense Scenarios Versus

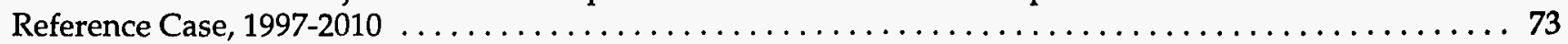

24. Estimate of Most Likely Potential Cumulative Savings in Uranium Procurement Costs for U.S. Nuclear Power Generating Companies from the Assumed Market Penetration of U.S. and

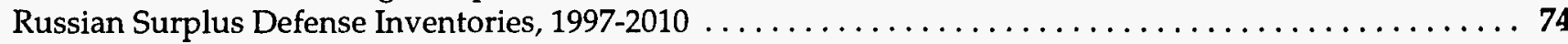

E1. Potential Availability of Uranium Feed from the Blending Down of Russian Highly Enriched Uranium to

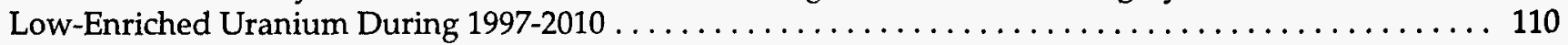

E2. Projected Spot-Market Prices for the Restricted U.S. Uranium Market, $1997-2010 \ldots \ldots \ldots \ldots \ldots \ldots$ 


\section{Executive Summary}

Nuclear materials declared by the U.S. and Russian governments as surplus to defense programs are being converted into fuel for commercial nuclear reactors. This report presents the results of an analysis estimating the market effects that would likely result from current plans to commercialize surplus defense inventories. The analysis focuses on two key issues: (1) the extent by which traditional sources of supply, such as production from uranium mines and enrichment plants, would be displaced by the commercialization of surplus defense inventories or, conversely, would be required in the event of disruptions to planned commercialization, and (2) the future price of uranium considering the potential availability of surplus defense inventories. Finally, the report provides an estimate of the savings in uranium procurement costs that could be realized by U.S. nuclear power generating companies with access to competitively priced uranium supplied from surplus defense inventories.

Arms reduction initiatives and the end of the Cold War have placed the governments of the United States and Russia in a position to declare portions of their nuclear weapons stockpiles as surplus. The two nations have agreed to store or dispose of their surplus nuclear materials in a safe and secure manner, so that they cannot be used for the proliferation of weapons of mass destruction.

The nuclear materials involved are principally highly enriched uranium (HEU)-containing at least 20 percent ${ }^{235} \mathrm{U}$, a fissionable uranium isotope-and plutonium. HEU can be "blended down" with uranium that contains low concentrations of ${ }^{235} U$ to produce low-enriched uranium (LEU) containing up to 5 percent ${ }^{235} U$. Plutonium can be blended with uranium oxide to form mixed oxide (MOX) fuel. Both LEU and MOX can be used as fuel in commercial nuclear power reactors. After these fuels have been burned in power reactors, they are discharged as spent fuel, which is highly radioactive and difficult to use for weapons manufacture.

In February 1993, the United States and Russia signed The Agreement between the Government of the United States and the Government of the Russian Federation Concerning the Disposition of Highly Enriched Uranium Extracted from Nuclear Weapons (the Russian HEU Agreement), which provided for the United States to purchase 500 metric tons of Russian HEU over a 20-year period. This "megatons to megawatts" agreement is the world's first program for converting weapons-grade nuclear materials from dismantled nuclear warheads to commercial reactor fuel for the generation of electricity. The United States Enrichment Corporation (USEC), a Government-owned corporation, will pay Russia only for the enrichment services component of the LEU derived from HEU. USEC sells the enrichment services component purchased from Russia in the commercial marketplace. The natural uranium feed component of the LEU can be sold separately by Russia.

On the U.S. side, an announcement by President Clinton in March 1995 declared some 200 metric tons of HEU and plutonium from U.S. defense programs as surplus. Inventories of natural uranium and LEU, already in commercially usable forms, also have been identified as surplus to U.S. defense programs. The commercialization of U.S. surplus defense materials is governed by a variety of laws and quotas, including the National Environmental Policy Act of 1969, the Energy Policy Act of 1992, and the USEC Privatization Act.

In sum, according to currently approved commercialization plans, Russian surplus inventories of HEU will provide the equivalent of about 398 million pounds of "natural" uranium concentrate $\left(\mathrm{U}_{3} \mathrm{O}_{8}\right)$ from mined ore to the commercial Western marketplace (excluding China and the Commonwealth of Independent States). U.S. surplus HEU will provide the equivalent of about 37 million pounds $\mathrm{U}_{3} \mathrm{O}_{8}$; and U.S. surplus $L E U$ and natural uranium will provide the equivalent of about 40 million pounds $\mathrm{U}_{3} \mathrm{O}_{8}$ (Figure ES1). In addition, the material contained in the surplus inventories will introduce equivalent uranium enrichment services into the commercial marketplace: 92 million separative work units (SWU) represented by Russian surplus material and 10 million SWU represented by U.S. surplus material. 
Figure ES1. Commerclallzatlon of U.S. and Russian Surplus Defense Inventorles Based on Approved Plans: Shares of Potentlal Uranium Supply by Inventory Type (Million Pounds $\mathrm{U}_{3} \mathrm{O}_{8}$ Equivalent)

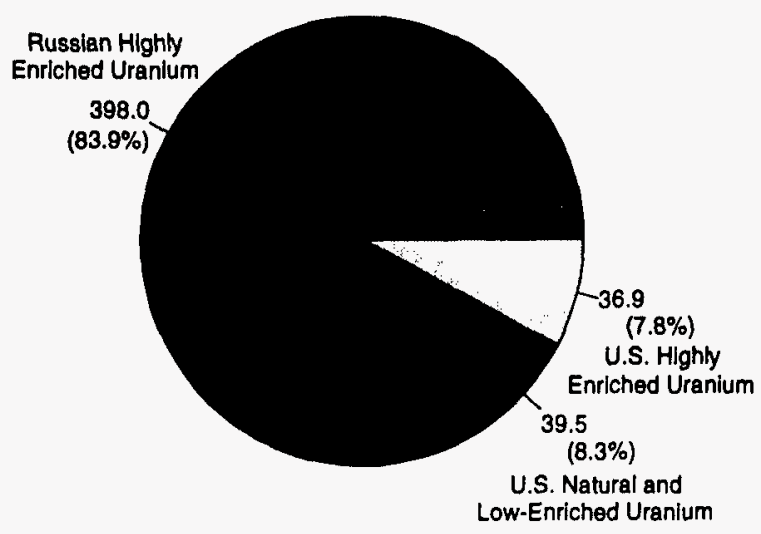

Sources: Russian HEU-Russian HEU Agreement. U.S. HEU, natural uranium, and LEU-U.S. Department of Energy disposition plans; United States Enrichment Corporation, 1996 Annual Report.

According to proposed U.S. government plans, a portion of U.S. surplus plutonium inventories would be fabricated into MOX fuel and burned in commercial power reactors. If approved, the utilization of this MOX fuel would displace the equivalent of around 17 million pounds $\mathrm{U}_{3} \mathrm{O}_{8}$. Because the plan is to make MOX available over a 15 year-period, the commercialization of plutonium would have only a marginal impact on the commercial uranium market.

At present, the legal maximum limit for deliveries of uranium derived from Russian HEU is scheduled to reach about 50 percent of projected U.S. commercial uranium requirements by 2010 (Figure ES2), although other policy and market factors are expected to limit sales of uranium from both U.S. and Russian surplus inventories to end users in the near term. In analyzing this issue, three scenarios were examined: a Reference Case, in which the quantity of uranium to be sold approximates the scheduled availability by 2005; a Lower HEU Feed Case, in which a portion of the Russian-origin material is withdrawn from the Western market for internal use; and an Upper HEU Feed Case, in which additional Russian-origin material not sold during 1997-2000 enters the Western market incrementally from 2002 through 2010 . The three scenarios are intended to illustrate different potential levels of market penetration by introduction of Russian and U.S. surplus defense inventories of nuclear materials.
Figure ES2. Legal Maximum Avallability of Uranium from the Commerclallzatlon of Russlan Highly Enriched Uranium as a Share of Projected U.S. Uranlum Requirements, 1997-2010

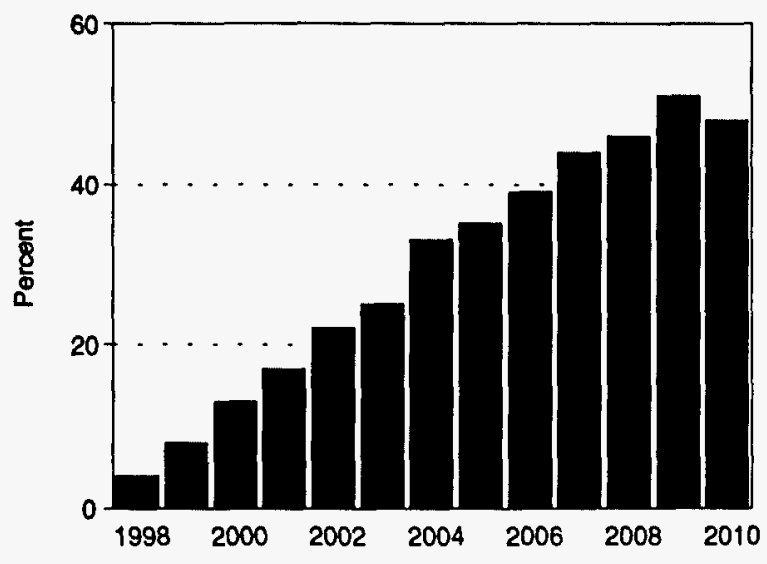

Sources: Projected U.S. uranium requirements-Energy Information Administration, Nuclear Power Generation and Fuel Cycle Report 1997, DOE/EIA-0436(97) (Washington, DC, September 1997), Table F1; U.S. quota-USEC Privatization Act (April 26, 1996), Section 3112 (b).

However, the proposed utilization of U.S. plutonium in MOX fuel was not considered in the scenarios.

The analysis results indicate that the spot-market price of $\mathrm{U}_{3} \mathrm{O}_{8}$ is expected to rise in all the scenarios (Figure ES3). Currently, Western requirements for uranium fuel exceed mine production. The difference is supplied by withdrawals from commercial inventories and imports from the Commonwealth of Independent States (CIS), including those from Russia. Because of restrictions placed on imports of CIS-origin uranium delivered to U.S. end users, there has been a price differential between the "restricted" and "unrestricted" markets since 1992. That differential is anticipated to diminish and, possibly, to disappear altogether with the increased availability of uranium derived from blending down Russian HEU. The average spot-market price for $\mathrm{U}_{3} \mathrm{O}_{8}$ on the restricted U.S. market is projected to range between $\$ 14$ and $\$ 17$ per pound by the middle of the next decade-higher than the lows seen in the mid-1990s but much lower than the peak prices of the 1970s and 1980s.

Over the next several years, U.S. and Russian surplus defense inventories are expected to become the second most important source of uranium, behind mine production. Nevertheless, the rise in spot-market price is projected to be sufficient to induce additional mine production. Mines in Australia and Canada with relatively 


\section{Figure ES3. Average Uranium Spot-Market Prlce, for the Restricted U.S. Market, 1985-2010}

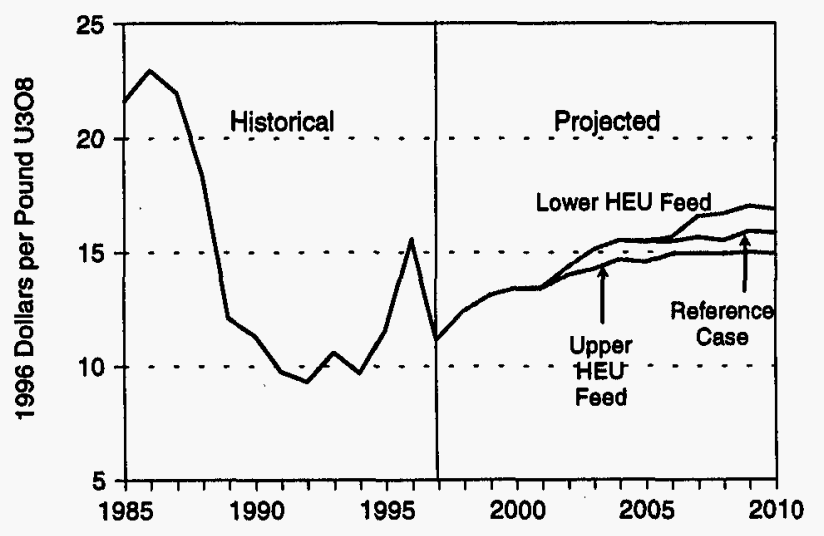

Sources: Historical spot-market price-annual average of Exchange Value reported in TradeTech, The Nuclear Review (October 1997); projected spot-market price-Energy Information Administration, Uranium Market Model, runs 1997_60, 1997_73, and 1997_82 (July 1997).

low production costs are projected to supply at least 70 percent of the $\mathrm{U}_{3} \mathrm{O}_{8}$ used to fuel Western reactors from 1997 through 2010. In the Lower HEU Feed Case, prices would be slightly higher than in the Reference Case (by less than $\$ 2$ per pound $\mathrm{U}_{3} \mathrm{O}_{8}$ ), and U.S. mine production would increase from just under 6 million pounds $\mathrm{U}_{3} \mathrm{O}_{8}$ in 1997 to 11 million pounds $\mathrm{U}_{3} \mathrm{O}_{8}$ per year by the end of the next decade.

Of course, market projections are subject to considerable uncertainty, and the commercialization of U.S. and Russian surplus inventories is especially sensitive to a variety of political and other considerations. An interruption in the inventory commercialization schedule could reduce the availability of natural uranium feed, requiring more expensive mine production and higher market prices to meet demand. Uncertainty with regard to the availability of supplies from Russian HEU could lead to volatile prices. Or, conversely, more aggressive marketing of the inventory material could drive prices down. On the demand side, construction deferrals and early retirements of nuclear power plants could reduce demand and, as a result, prices for nuclear fuel. Retirements of nuclear power plants considered in the analysis are based on assumptions made for the reference case projections published in the Energy Information Administration's Nuclear Power Generation and Fuel Cycle Report 1997.

The enrichment services market, with a current excess of capacity, is less subject to the price volatility that has been seen in the uranium market over the past decade. Marketable enrichment service (SWUs) derived from surplus defense inventories will largely be controlled by USEC, which is expected to sell the excess through longterm contracts (rather than on the spot market) in order to avoid price fluctuations that would affect its own business. It is also possible that USEC could begin marketing LEU as "enriched uranium product" (EUP) directly to end users, as opposed to the typical practice of just providing enrichment services for natural uranium already owned by the end users. (Russia could also become a major supplier of EUP, but current trade restrictions limit the penetration of Russian-origin uranium in the Western market.) In the United States, as the deregulation of electricity markets progresses, electricity generators with nuclear facilities could find advantages in purchasing EUP, through greater flexibility and lower costs of inventory management.

The availability of competitively priced uranium derived from U.S. and Russian surplus defense inventories is expected to lower uranium procurement costs for U.S. nuclear power generating companies below levels that would prevail if the market were supplied entirely by newly produced uranium. Assuming that commercialization of the surplus inventories proceeds on schedule, and then considering the most likely of three scenarios regarding potential uranium supply, the cumulative savings in uranium procurement costs for U.S. electricity producers in 1996 dollars are estimated to be between \$2.9 billion and \$3.4 billion from 1997 through 2010 (Figure ES4). The estimate of potential cumulative savings is considered the most likely from a broad range projected between $\$ 2.1$ billion and $\$ 5.3$ billion dollars in 1996 dollars. Savings in the higher end of the range would be realized if the development of known low-cost reserves is restricted through government policy. On the other hand, the savings could be less than the most likely estimate if new low-cost reserves are discovered and put into production during the forecast period.

The total effect of commercializing U.S. and Russian surplus defense inventories on nuclear power generating companies' fuel costs would also depend on the behavior of the enrichment services market. Under the current condition of worldwide production overcapacity, the price of SWU in constant dollars is not anticipated to rise appreciably. USEC is expected to sell the SWU it receives as U.S. Executive Agent for the Russian HEU Agreement in a market neutral manner. It is assumed that most of the potential effect of commercializing surplus defense inventories on fuel procurement costs could be measured by changes in the price of uranium. With access to U.S. and Russian SWU, USEC 
Figure ES4. Potential Cumulative Savings in U.S. Uranium Procurement Costs Based on the Availability of U.S. and Russian Surplus Defense Inventories, 1997-2010

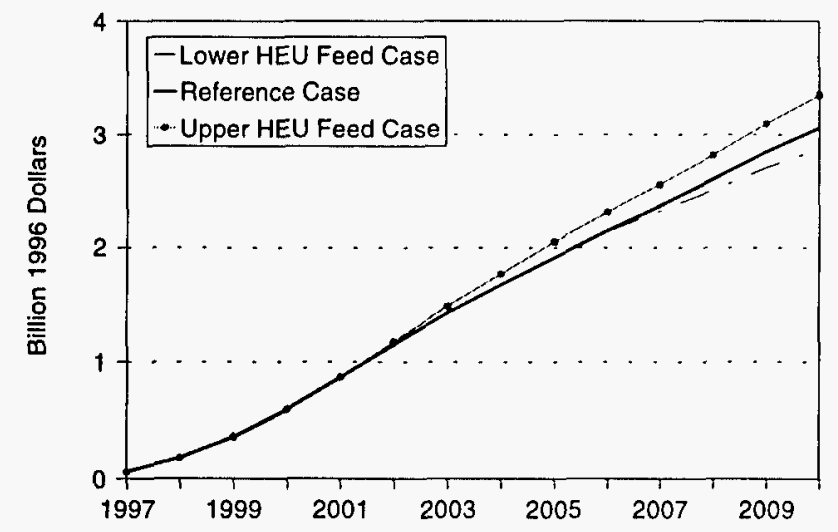

Note: It is assumed that changes in all contract prices are highly correlated to changes in the projected spotmarket price. The estimation of potential cumulative savings is based on the projected decline in uranium spot-market price as a result of the penetration into the marketpace of U.S. and Russian surplus defense inventories assumed for the three specific cases compared to a no surplus defense scenario.

Source: Projected spot-market price-Energy Information Administration, Uranium Market Model, runs 1997_60, 1997_73, 1997_82, and 1997A_21. could elect to close one of its enrichment plants. Under a plant closure scenario, the price of SWU could rise in response to a decline in excess capacity. However, any increase in the cost of enrichment services is expected only to offset partially the impact of lower uranium price on reducing total fuel procurement costs. 


\section{Introduction}

The atomic age was created out of an urgency in wartime to harness the energy of atomic fission for use in producing weapons of mass destruction. The scientists who succeeded in making the first atomic bomb in 1945 also envisioned that atomic power would provide many peaceful benefits to mankind. One such benefit would be the generation of electricity. However, nearly a decade passed before construction was begun on the first commercial-scale nuclear power plants. Meanwhile, the United States and the Soviet Union, the world's superpowers, had become engaged in an arms race, leading to the buildup of large stockpiles of nuclear weapons.

National defense programs are thought to have used over half of the 4.7 billion pounds of uranium oxide $\left(\mathrm{U}_{3} \mathrm{O}_{8}\right)$ estimated to have been extracted from the earth since $1945 .^{1}$ In addition to its use in the manufacture of weapons-grade fissile materials, especially highly enriched uranium (HEU) and plutonium, uranium also has been used to produce fuel to propel naval vessels and in various research applications. Nevertheless, large quantities of uranium and plutonium produced for national defense purposes remain in inventory.

In his address to the United Nations General Assembly in December 1953, President Dwight D. Eisenhower proposed "Atoms for Peace" a program in which governments would make "joint contributions from their stockpiles of normal uranium and fissionable materials to an international atomic energy agency." 2 This bank of nuclear materials would serve the "peaceful pursuits of mankind," especially to provide electrical energy. Although President Eisenhower recognized that the initial contributions would be small, Atoms for Peace was the first serious proposal for converting uranium and plutonium that were stockpiled for defense purposes into fuel for generating electricity.

Four decades later, the vision advanced in Atoms for Peace became reality. The precursor for such an achievement was met when the United States and the Soviet Union agreed in 1991 to substantially reduce their nuclear armaments. The dissolution of the Soviet Union later in that year all but ended the cold war between the two nuclear superpowers. After the dissolution, the Russian Federation (Russia) had assumed control of the former Soviet nuclear weapons stockpiles as well as the responsibility to abide by existing arms reduction agreements. ${ }^{3}$ As additional arms reduction initiatives were undertaken, it became apparent that the HEU and plutonium contained in the tens of thousands of nuclear weapons being dismantled would require safe storage and disposition. Of particular concern was the proliferation of nuclear weapons that could arise from the unauthorized use of these fissile materials. ${ }^{4}$ As a result, the conversion of surplus fissile materials from dismantled nuclear weapons into fuel for commercial nuclear power plants was included as a strategy in President Clinton's Nonproliferation and Export Control Policy. ${ }^{5}$

A government-to-government agreement signed by the United States and Russia in 1993 established the terms for the world's first conversion of fissile materials contained in weapons to commercial nuclear fuel (Table 1). As a result, the first fuel derived from HEU taken from dismantled Russian nuclear warheads was delivered to a U.S. electric power utility in November 1995. By the end of 1997, the HEU that had been converted in Russia for use in reactor fuel was equivalent to over 1,600 nuclear warheads. ${ }^{6}$ Required to

1 Uranium Institute, The Global Nuclear Fuel Market: Supply and Demand 1995-2015 (London, 1996), pp. 67-70.

2 Address by Dwight D. Eisenhower, President of the United States of America, to the 470th Plenary Meeting of the United Nations General Assembly (December 8, 1953).

3 At the time of the dissolution of the Soviet Union, nuclear weapons were also stationed in the newly independent republics of Belarus, Kazakhstan, and Ukraine. All have since been removed. The Governments of Kazakhstan and Ukraine required that the nuclear weapons removed from their territories be dismantled.

4 Proliferation refers to the spread of nuclear weapons capability outside countries that currently possess nuclear weapons.

5 The White House, Office of the Press Secretary, Nonproliferation and Export Control Policy Fact Sheet (Washington, DC, September 27, 1993).

6 United States Enrichment Corporation, Megatons to Megawatts Program Progress Status (Bethesda, MD, December 1997). 
Table 1. U.S. and Russian Surplus Defense Inventorles Considered in This Report

\begin{tabular}{|c|c|c|}
\hline Country & Inventory & Source \\
\hline Russia & Highly Enriched Uranium (HEU) & $\begin{array}{l}\text { Russian HEU Agreement 1993; implementation contract } \\
\text { 1994, amended } 1996\end{array}$ \\
\hline \multirow[t]{3}{*}{ United States } & Highly Enriched Uranium (HEU) & $\begin{array}{l}\text { U.S. Department of Energy, Record of Decision for the } \\
\text { Disposition of Surplus HEU, July } 1996\end{array}$ \\
\hline & $\begin{array}{l}\text { Natural uranium and low-enriched } \\
\text { uranium (LEU) }\end{array}$ & $\begin{array}{l}\text { U.S. Department of Energy, Environmental } \\
\text { Assessment of the Proposed Sale of DOE Surplus Natural } \\
\text { and Low Enriched Uranium, October } 1996\end{array}$ \\
\hline & Plutonium (see note) & $\begin{array}{l}\text { U.S. Department of Energy, Record of Decision for the } \\
\text { Storage and Disposition of Weapons-Usable Fissile } \\
\text { Materials, December } 1996\end{array}$ \\
\hline
\end{tabular}

Note: U.S. Government surplus plutonium was not considered for the three analysis cases presented in this report.

conform to stringent regulations, U.S. disposition activities have lagged behind the conversion of Russian HEU. Nevertheless, the U.S. Government announced plans in 1996 for the commercialization of U.S.-origin HEU and plutonium, as well as natural uranium already in forms that can be used without further conversion to produce fuel for commercial reactors (Table 1). Russia announced plans in 1996 for the disposition of weapons-grade plutonium.

Under currently approved plans for the disposal of U.S. and Russian surplus defense HEU and natural uranium, the equivalent of nearly 500 million pounds $\mathrm{U}_{3} \mathrm{O}_{8}$ would be made available over the next 15 to 20 years for use in producing commercial nuclear fuel. The total quantity corresponds to the uranium projected to be required for all the world's reactors over the period 1997-1999 (442 commercial nuclear power reactors were operable in the world as of December 31, 1996). ${ }^{7,8}$ Proposed plans for using surplus plutonium in fuel for U.S. and Russian reactors could displace some uranium by the middle of the next decade. The quantity of plutonium declared as surplus by the U.S. and Russian governments corresponds to fuel for 100 reactor-years of operation with current technologies, ${ }^{9}$ equivalent to less than 1 year of fuel requirements for the 110 U.S. reactors operable as of December 31, 1996. ${ }^{10}$ However, not all surplus plutonium is intended for use in commercial nuclear power plants. Some of it will be immobilized in combination with other materials and placed in a geologic repository. Because Russian commercial nuclear fuel requirements are filled only from internal sources, the effects on the world nuclear fuel market of the decision by the Russian government to burn surplus plutonium in commercial reactors is not considered in this report.

This report is divided into two sections: (1) materials and policies, and (2) market effects. Background information about the nuclear materials and the policies involved in U.S. and Russian government commercialization plans is provided in Chapters 1 through 5 . The last two chapters focus on the potential market effects of commercialization. An assessment of the key market penetration factors is presented in Chapter 6 . Chapter 7 provides an analysis of the effects of U.S. and Russian surplus defense inventories based on different scenarios of market penetration.

\footnotetext{
7 EIA projects annual world requirements to be 483 million pounds $\mathrm{U}_{3} \mathrm{O}_{k}$ over the 3-year period, 1997-1999. See Energy Information Administration, Nuclear Power Generation and Fucl Cycle Report 1997, DOE/EIA-0436(97) (Washington, DC, September 1997), Table F2.

${ }^{8}$ Energy Information Administration, Nuclear Power Generation and Fuel Cycle Report 1997, DOE/EIA-0436(97) (Washington, DC, September 1997), Table D1.

9 Final Report of the U.S.-Russian Independent Scientific Commission on Disposition of Excess Weapons Plutonium, June 1, 1997, released by The White House Office of Science and Technology (Washington, DC, September 10, 1997), p. 9.

${ }^{10}$ Energy Information Administration, Nuclear Power Generation and Fuel Cycle Report 1997, DOE/EIA-0436(97) (Washington, DC, September 1997), p. ix.
} 
Materials and Policies 


\section{Relationship Between Military and Civilian Nuclear Programs}

\section{Government Role in Nuclear Energy}

With the advent of the atomic age in the 1940s, largescale industries were built by the governments of the United States and the Soviet Union to develop and manufacture nuclear weapons, produce fuel for submarines and surface vessels, and conduct research on various nuclear applications. The Atomic Energy Act of 1946 created the U.S. Atomic Energy Commission (AEC) and placed nuclear weapons production in the United States under civilian-government management. The management of nuclear materials stockpiled for national security purposes, a function formerly held by the AEC, is currently carried out by the U.S. Department of Energy (DOE).

By the mid-1950s, government programs were in place to demonstrate peaceful uses for nuclear energy, including the generation of electricity. Nuclear power was first used to supply electricity for a civilian population in 1954, with the startup of a reactor in Obninsk, Russia. Calder Hall in the United Kingdom (1956) and Shippingport in the United States (1957) became the first commercial-scale reactors to be connected to electricity grids in the Western world. The ownership of nuclear materials and the facilities used to produce fuel for the first civilian reactors remained under government control. In the United States, privatesector utilities purchased or leased nuclear fuel directly from the AEC.

The United States was the first country to relax its policy of government control over the production of nuclear fuel for civilian uses. In 1964, the Private Ownership of Nuclear Materials Act was passed to give private individuals the right to own nuclear materials. As a result, companies that mined uranium and produced fuel for civilian nuclear reactors under contract to the AEC could enter into commercial contracts directly with utilities. However, the U.S. Government continued its ownership of domestic enrichment services facilities, which were used to produce both low-enriched uranium (LEU) for civilian use and HEU for defense purposes. In 1970 , the U.S. Government ended its uranium procurement program, giving rise to the present-day wholly commercial nuclear fuel market. As described in the box on page 18, legislation passed in 1992 authorized the U.S. Government to privatize its enrichment activities. When this privatization becomes fully implemented, the U.S. Government will no longer have a management role in the production of commercial nuclear fuel. ${ }^{11}$

With the breakup of the Soviet Union in 1991, Russia gained control of most the former Soviet nuclear industry. In Russia, the civilian and military nuclear programs remain integrated. The Ministry of Atomic Energy for the Russian Federation (MINATOM) controls all aspects of the nuclear fuel cycle along with nuclear power generation for civilian use. MINATOM has no plans to privatize the Russian civilian nuclear program. Other countries-notably, China, France, and the United Kingdom-also have developed nuclear weapons; however, their inventories of HEU and plutonium are much smaller than those held by the United States and Russia. Of the world's nuclear weapons states, only the United States and Russia have announced plans to dispose of surplus inventories of HEU and plutonium. ${ }^{12}$

\section{Relationship Between the Civilian and Military Nuclear Fuel Cycles}

Naturally occurring uranium is transformed into weapons materials and fuel through a series of steps referred to as the nuclear fuel cycle (Figure 1). The "front end" of the nuclear fuel cycle encompasses the steps necessary for producing nuclear fuel from naturally occurring uranium. The storage and processing of spent fuel is the "back end" of the cycle. Spent fuel removed from reactors is typically stored for a period of

11 Two gaseous diffusion enrichment plants, owned by the U.S. Government, will be leased to the privatized company.

12 Nuclear weapons states are countries which have manufactured and exploded a nuclear device prior to January $1,1967$. 
Figure 1. Relationship of Military and Civilian Nuclear Fuel Cycles

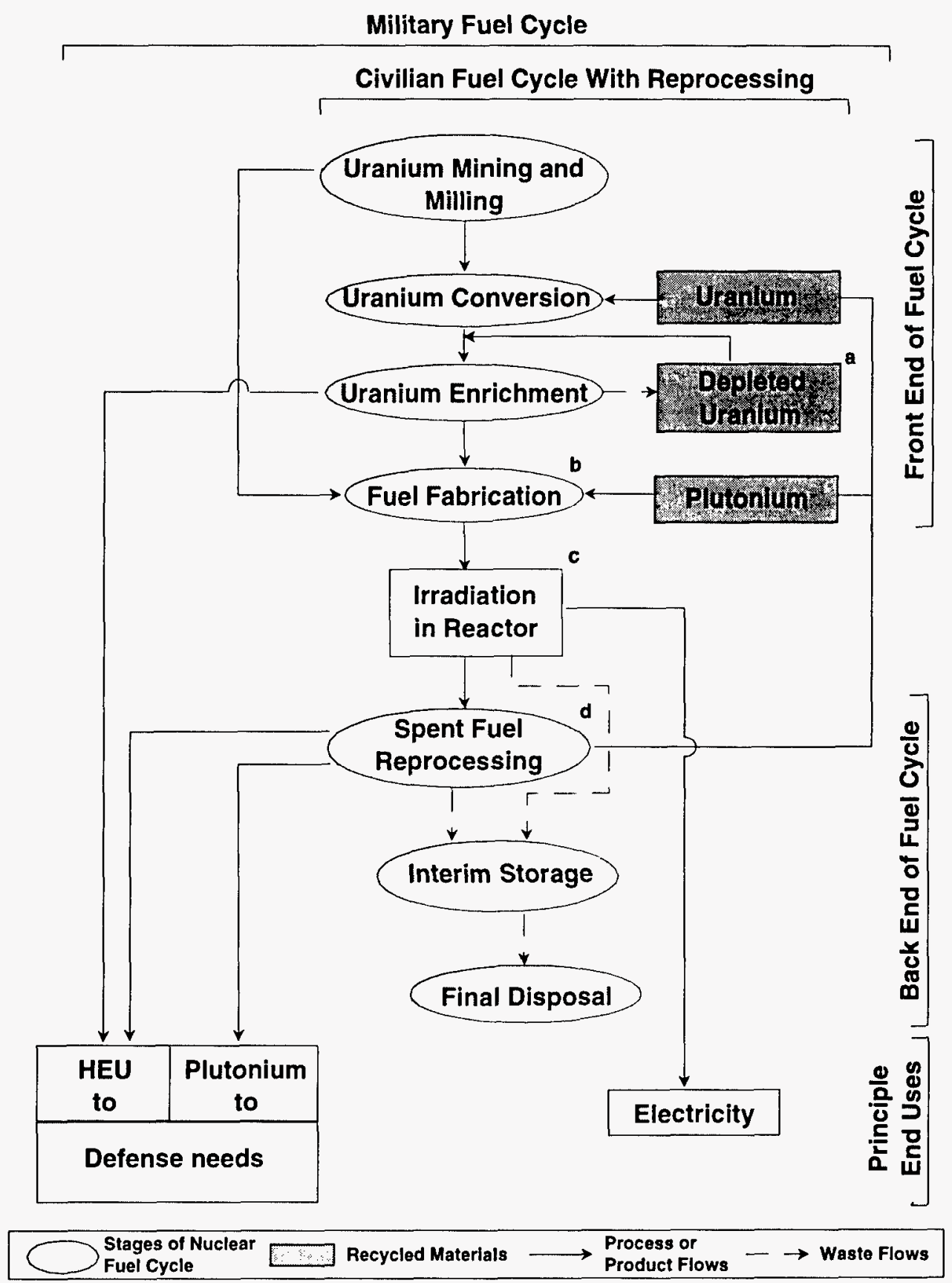

aThe portion of the uranium product stream that becomes depleted in ${ }^{235} \mathrm{U}$ during enrichment, generally considered as waste in Western countries, is recycled in the Russian Federation.

bPlutonium-production reactors for military use and some civilian reactors, notably CANDU reactors, are operated with fuel fabricated from natural uranium.

${ }^{c}$ Certain reactors have been operated for the sole purpose of producing weapons-grade plutonium without filling civilian power needs.

'Spent fuel is no longer reprocessed in the United States.

$\mathrm{HEU}=$ Highly enriched uranium.

Notes: HEU is no longer produced in the United States or Russia; weapons-grade plutonium is no longer produced in the United States.

Source: Energy Information Administration, Office of Coal, Nuclear, Electric and Alternate Fuels. 
time to allow for cooling through radioactive decay. After this "interim storage" phase, spent fuel can be prepared for final disposal in a managed, safe, and secured repository, or it can be reprocessed to recover uranium and plutonium for recycling.
A commercial market has been established for the various products and services representing each frontend step of the civilian nuclear fuel cycle (Table 2). Utilities in the Western world have traditionally filled a large share of their reactor requirements by purchasing

Table 2. Commercial Nuclear Fuel Markets

\begin{tabular}{|c|c|c|c|}
\hline Fuel Cycle Step & $\begin{array}{c}\text { Marketable } \\
\text { Product or Service }\end{array}$ & $\begin{array}{l}{ }^{235} \mathrm{U} \text { Content of } \\
\text { Product }\end{array}$ & Technical Comments \\
\hline $\begin{array}{l}\text { Uranium mining and } \\
\text { milling or processing }\end{array}$ & $\begin{array}{l}\text { Uranium oxide }\left(\mathrm{U}_{3} \mathrm{O}_{8}\right) \\
\text { also called uranium } \\
\text { concentrate, or yellowcake }\end{array}$ & $\begin{array}{l}\text { Natural uranium: } \\
0.7 \text { percent }\end{array}$ & $\begin{array}{l}\text { Milling involves crushing, grinding, and separation } \\
\text { to extract } \mathrm{U}_{3} \mathrm{O}_{8} \text { from ore. Processing is used to } \\
\text { denote the method of recovering } \mathrm{U}_{3} \mathrm{O}_{8} \text { from } \\
\text { uranium-bearing solutions or concentrates } \\
\text { produced primarily from the ores of other } \\
\text { commodities. }\end{array}$ \\
\hline \multirow[t]{2}{*}{ Conversion } & Conversion & Service, not product & $\begin{array}{l}\text { Converter provides service whereby utility-owned } \\
\mathrm{U}_{3} \mathrm{O}_{8} \text { is chemically converted into } \mathrm{UF}_{6} \text {, the } \\
\text { feedstock (when heated to a gas) required for } \\
\text { enrichment. }\end{array}$ \\
\hline & $\begin{array}{l}\text { Uranium hexaflouride } \\
\left(\mathrm{UF}_{6}\right)\end{array}$ & $\begin{array}{l}\text { Natural uranium: } \\
0.7 \text { percent }\end{array}$ & $\begin{array}{l}\text { Utilities can purchase } \mathrm{UF}_{6} \text { in the market, thereby } \\
\text { reducing costs for holding inventories of } \mathrm{U}_{3} \mathrm{O}_{8} \text {. }\end{array}$ \\
\hline \multirow[t]{2}{*}{ Enrichment } & $\begin{array}{l}\text { Separative Work Units } \\
\text { (SWU) }\end{array}$ & Service, not product & $\begin{array}{l}\text { Enricher provides service whereby the }{ }^{235} \mathrm{U} \\
\text { content of utility-owned natural } \mathrm{UF}_{6} \text { is increased to } \\
\text { low-enriched uranium (as } U F_{6} \text { ) that will support } \\
\text { nuclear fission in a reactor. }\end{array}$ \\
\hline & $\begin{array}{l}\text { Enriched uranium product } \\
\text { (EUP) }\end{array}$ & $\begin{array}{l}\text { Low-enriched } \\
\text { uranium (LEU): } \\
\text { typically } 3.0-5.0 \\
\text { percent for reactor } \\
\text { fuel }\end{array}$ & $\begin{array}{l}\text { Utilities can purchase EUP in the market, thereby } \\
\text { reducing costs for holding inventories of } \mathrm{U}_{3} \mathrm{O}_{8} \text { and } \\
\text { natural } \mathrm{UF}_{6} \text {. }\end{array}$ \\
\hline \multirow[t]{2}{*}{ Fuel fabrication } & Fuel assemblies-uranium & $\begin{array}{l}\text { Low-enriched } \\
\text { uranium (LEU), } \\
\text { typically } 3.0-5.0 \\
\text { percent, for light- } \\
\text { water reactors, or } \\
\text { natural uranium, } 0.7 \\
\text { percent, for } \\
\text { Canadian } \\
\text { deuterium-uranium } \\
\text { (CANDU) reactors. }\end{array}$ & $\begin{array}{l}\text { Typically, a utility delivers LEU in the form of } U F_{6} \\
\text { to fabricator. Fabricators have also developed the } \\
\text { capability of using other uranium compounds, } \\
\text { including uranyl nitrate hexahydrate }(U N H) \text {, as a } \\
\text { feedstock. Fabricator converts } U F_{6} \text { or UNH into } \\
\text { uranium oxide }\left(\mathrm{UO}_{2}\right) \text { pellets for loading into fuel } \\
\text { rods, and bundles fuel rods into assemblies for } \\
\text { loading into reactor core. Fabricator also provides } \\
\text { engineering and warranty services. }\end{array}$ \\
\hline & $\begin{array}{l}\text { Fuel assemblies-mixed } \\
\text { oxide (MOX) }\end{array}$ & See comments & $\begin{array}{l}\text { MOX fuel contains around } 5 \text { percent plutonium } \\
\text { oxide. The remainder is uranium oxide typically } \\
\text { having a }{ }^{235} \mathrm{U} \text { content of } 0.7 \text { percent or less. The } \\
\text { plutonium comes from reprocessing spent nuclear } \\
\text { fuel. Reprocessing of spent fuel or the use of } \\
\text { MOX fuel is not currently being undertaken in the } \\
\text { United States. Fabricator also provides } \\
\text { engineering and warranty services. }\end{array}$ \\
\hline
\end{tabular}

Source: Energy Information Administration, Office of Coal, Nuclear, Electric and Alternate Fuels. 
$\mathrm{U}_{3} \mathrm{O}_{8}$, then contracting for services to convert, enrich, and fabricate the uranium to fuel that meets reactor specifications, with contracts structured to ensure deliveries for up to 10 years. ${ }^{13}$ Because of the considerable variation in reactor designs and licensing requirements, nuclear power plant operators and fuel fabricators have often entered into long-term relationships that include the designing, engineering, and performance enhancement of fuel.

Utilities had entered into long-term contracts with suppliers to cover the uranium requirements anticipated for planned nuclear power plants. With the cancellation of some reactor construction programs, beginning in the 1970s, a buildup of excess inventories occurred as utilities were forced to accept delivery of uranium that was no longer required. The excess supplies were sold in a secondary market. Purchases of excess inventories continue to meet a large share of demand. For example, around 90 million pounds of $\mathrm{U}_{3} \mathrm{O}_{8}$ were produced from the world's mines during $1996,{ }^{14}$ compared to 1997 world requirements projected at about 165 million pounds $\mathrm{U}_{3} \mathrm{O}_{8}{ }^{15}$ The shortfall between primary production and requirements is expected to be made up largely through the liquidation of excess inventories. Since the late 1980s, China and the republics of the former Soviet Union have sold $\mathrm{UF}_{6}$ and enriched uranium product (EUP) to the West, giving consumers the opportunity to acquire uranium at different steps of the fuel cycle, thereby reducing holding costs and providing greater flexibility to manage fuel costs.

In contrast to Western countries, all nuclear fuel cycle requirements of China and Russia are met from fully integrated domestic industries wholly controlled by the respective national governments. Present policies for energy self-sufficiency have precluded China or Russia from making import transactions in the commercial market. Besides exports to the West, Russia also has longstanding commitments to provide integrated nuclear fuel cycle services for countries in Eastern Europe that operate Russian-built reactors.

The production of HEU and plutonium for use in weapons and other national defense purposes requires many of the same steps involved in the civilian nuclear fuel cycle. Thus, many of the same government facilities constructed for military programs have been used to produce fuel for civilian nuclear power reactors. The relationship between the civilian and military fuel cycles has prompted international concerns that nuclear materials in the civilian sector could be used for manufacturing nuclear weapons. To counter the threat of nuclear weapons proliferation, 185 countries have agreed to implement nuclear materials safeguards developed and monitored by the International Atomic Energy Agency (IAEA). ${ }^{16}$ IAEA's safeguards involve accounting and verification procedures designed to detect unauthorized diversions of nuclear materials that could occur in the commercial fuel cycle. To further expand nuclear safeguards, the United States has voluntarily agreed to allow the IAEA to inspect certain inventories of U.S. HEU and plutonium no longer needed for national defense purposes. ${ }^{17}$

Most of the world's commercial nuclear power plants operate light-water reactors that use LEU as fuel. ${ }^{18,} 19$ LEU is produced by increasing the relative concentration of ${ }^{235} \mathrm{U}$, the fissile isotope of uranium, from 0.7 percent contained in natural uranium recovered from the earth to between 3 and 5 percent. ${ }^{20}$ This process of increasing the relative content of ${ }^{235} \mathrm{U}$ in uranium is referred to as enrichment. HEU is produced by further enriching uranium to 20 percent or higher ${ }^{2.35} U$ content in the same type of plant used to produce LEU. HEU differs from LEU in that it can sustain fast-neutron chain reactions at the level required for a nuclear explosion. HEU with a ${ }^{235} \mathrm{U}$ content of 90 percent or greater is considered to be "weapons grade."

${ }^{13}$ The Western world does not include China or the Commonwealth of Independent States.

${ }_{14}$ International Atomic Energy Agency, World Uranium Production and Nuclcar Share, Fact Shcet (October 16, 1997).

${ }^{15}$ Because natural uranium is converted to nuclear fuel through the various nuclear fuel cycle steps, most $\mathrm{U}_{3} \mathrm{O}_{8}$ purchases in 1996 will be used to fill requirements in succeeding years. Projected world requirements for 1997 come from Energy Information Administration, Nuclear Power Generation and Fuel Cycle Report 1997, DOE/EIA-0436(97) (Washington, DC, September 1997 ), Table F1.

${ }_{16}$ The International Atomic Energy Agency, founded in 1957, is an independent intergovernmental organization within the United Nations. Its mission includes promoting the peaceful use of atomic energy and ensuring that the processes employed in the civilian nuclear industry are not used to further military purposes.

${ }^{17}$ U.S. Department of Energy, "Pena Doubles Amount of U.S. Plutonium and Highly Enriched Uranium Available for International Inspection," press release (Washington, DC, September 29, 1997).

${ }^{18}$ See glossary for definition of light-water reactor.

19 A notable exception is the Canadian deuterium-uranium (CANDU) reactor, which uses fuel made from natural uranium.

${ }^{20}$ Fissile isotopes are capable of sustaining a nuclear chain reaction. 
HEU can be diluted by blending it with uranium that has a very low ${ }^{235} U$ content. The blendstock, also referred to as diluent, can be made up of natural uranium, slightly enriched uranium, or uranium depleted in ${ }^{235} \mathrm{U}$ as a consequence of the enrichment process. ${ }^{21}$ The resulting product, commercial-grade LEU, is categorized as "indirect-use material" by the IAEA.22 Expensive, time-consuming processes would be required to produce HEU from LEU.

Plutonium is a byproduct of uranium that has been irradiated in nuclear reactors. It has been produced both in civilian reactors used to generate electricity and in government reactors operated specifically to produce plutonium for weapons. Before plutonium can be utilized, it must be recovered through the reprocessing of spent fuel removed from nuclear reactors. Plutonium separated from civilian spent fuel is classified as reactor grade, containing between 55 and 80 percent fissile isotopes, principally ${ }^{239} \mathrm{Pu}$. In contrast, weapons-grade plutonium contains more than 93 percent fissile plutonium. To produce weapons-grade plutonium, plutonium-production reactors typically were operated at burnups of less than 5,000 megawattdays thermal per metric ton of initial heavy metal (MWDT/MTIHM). ${ }^{23}$ In contrast, civilian nuclear power reactors operate at burnup rates of between 30,000 and 50,000 MWDT/ MTIHM. ${ }^{24}$ Because of the less complete burnup, plutonium-production reactors have generated a relatively greater amount of spent fuel per fuel load than civilian nuclear power reactors.

The world's civilian nuclear power reactors produce about 70 metric tons of reactor-grade plutonium per year, adding to the more than 1,000 metric tons already produced. ${ }^{25}$ Most of this plutonium remains in spent fuel assemblies. The IAEA estimates, that at the end of 1996, civilian stockpiles contained 160 metric tons of reactor-grade plutonium separated from reprocessed spent fuel. ${ }^{26}$ The separated plutonium is used in the manufacture of mixed-oxide fuel for commercial use (see text box, page 10). Although less preferable than weapons-grade plutonium for manufacturing nuclear weapons, reactor-grade plutonium is considered by the IAEA as a direct-use material. ${ }^{27}$

${ }^{21}$ During enrichment, the natural $\mathrm{UF}_{6}$ feedstock is separated into two streams having different concentrations of ${ }^{235} \mathrm{U}$. One stream is LEU, the desired commercial product. The other stream is depleted in ${ }^{235} \mathrm{U}$ relative to either the natural uranium feedstock or the LEU. It typically contains between 0.20 percent and 0.30 percent ${ }^{235} \mathrm{U}$ and is referred to as "enrichment tails."

${ }_{22}$ N. Harms, and P. Rodriguez, "Safeguards at Light-Water Reactors: Current Practices, Future Directions," IAEA Bulletin, Quarterly Journal of the International Atomic Energy Agency, Vol. 38, No. 4 (December 1996), p. 16

${ }^{23}$ U.S. Department of Energy, Plutonium: The First 50 Years (Washington, DC, February 1996), pp. 25-30.

${ }^{24}$ Energy Information Administration, Nuclear Power Generation and Fuel Cycle Report 1997, DOE/EIA-0436(97) (Washington, DC, September 1997), p. 51 and Table B6.

${ }^{25}$ Final Report of the U.S.-Russian Independent Scientific Commission on Disposition of Excess Weapons Plutonium, June 1, 1997, released by The White House Office of Science and Technology (Washington, DC, September 10, 1997), p. 9.

${ }^{26} \mathrm{H}$. Blix, "Opening Address," in Nuclear Fuel Cycle and Reactor Strategies, Contributed papers from International Symposium held in Vienna, June 3-6, 1997, International Atomic Energy Agency LAEA-TECDOC-990 (Vienna, Austria, December 1997), p. 12.

${ }^{27}$ N. Harms, and P. Rodriguez, "Safeguards at Light-Water Reactors: Current Practices, Future Directions," IAEA Bulletin, Quarterly Journal of the International Atomic Energy Agency, Vol. 38, No. 4 (December 1996), p. 16 


\section{Commercial Recycling of Uranium and Plutonium from Spent Fuel}

In most of the world's nuclear power plants, a "once-through" use of uranium fuel is followed by either storage or direct disposal of spent fuel. However, some countries during the past 30 years have been recycling the uranium and plutonium contained in spent fuel discharged from civilian nuclear power reactors. The main reason for recycling is to reduce the growing accumulations of discharged spent fuel. In addition, a fully integrated domestic recycling program serves to reduce a country's reliance on uranium imports.

Spent fuel discharged from civilian reactors contains approximately 96 percent uranium and 1 percent plutonium. Uranium and plutonium are separated from spent fuel through reprocessing. Reprocessing is currently being undertaken in France and the United Kingdom. Also, a pilot-scale reprocessing plant is operating in Japan. During reprocessing, rods containing the spent fuel are physically broken apart. Uranium and plutonium are then chemically separated from each other and associated waste products. The separated uranium contains less than 1 percent ${ }^{235} \mathrm{U}$. It can be recycled for use in preparing fresh nuclear fuel in the following ways: (1) direct use in combination with plutonium or (2) conversion to $U F_{6}$ and subsequent enrichment to LEU. Recycled uranium differs in isotopic composition from natural uranium. Because of the presence of ${ }^{232} \mathrm{U},{ }^{234} \mathrm{U}$, and ${ }^{236} \mathrm{U}$, recycled uranium must undergo special radioactive protection measures and additional processing to make it amenable for nuclear fuel.

The fissile isotopes ${ }^{239} \mathrm{Pu}$ and ${ }^{241} \mathrm{Pu}$, contained in plutonium separated from spent fuel, can be used as a partial substitute for LEU fuel in light-water reactors. For this purpose, typically up to 5 percent fissile plutonium in oxide form is fabricated with around 95 percent uranium oxide to produce a mixed-oxide (MOX) fuel. The uranium oxide used in MOX fuel generally comes from natural uranium, recycled uranium, or depleted uranium from enrichment tails. MOX fuel fabricating plants are currently operating in Belgium, France, and the United Kingdom. A MOX fuel fabrication plant is planned for commercial operation in Japan after 2000.

When utilized, MOX fuel typically makes up around 30 percent of the fuel loaded into a light-water reactor, the remainder being LEU. This mix provides reactors with the same operating and energy output characteristics as fuel comprised wholly of LEU. Since MOX fuel contains plutonium, less overall uranium is required by reactors. Based on expected increases in demand and supply capability, EIA projects that the use of MOX fuel will reduce the world's average annual uranium requirements by around 8 percent through 2015 (see note).

MOX fuel is currently being used in commercial nuclear power reactors in Belgium, France, Germany, Japan, Switzerland, and the United Kingdom. In the United States, however, government policy on nonproliferation has resulted in the indefinite deferral of commercial reprocessing and recycling of plutonium since 1977. President Clinton's Nonproliferation and Export Control Policy, announced in September 1993, reaffirms this policy. It states that "the United States does not encourage the civil use of plutonium and, accordingly, does not itself engage in plutonium reprocessing for either nuclear power or nuclear explosive devices." However, the United States has not opposed reprocessing in Europe and Japan.

Note: Projections of MOX fuel utilization by EIA were made under the following assumptions: (1) countries using MOX fuel will continue to do so and will gradually incorporate the use of MOX fuel into additional reactors and (2) there is sufficient reprocessing capability to satisfy MOX fuel demand over the projection period.

Sources: Reprocessing and recycling-Energy Information Administration, "New Sources of Nuclear Fuel," in Electric Power Monthly, DOE/EIA-0226(95/09), pp. ix-xix; MOX fuel utilization-Energy Information Administration, Nuclear Power Generation and Fuel Cycle Report 1997, DOE/EIA-0436(97) (Washington, DC, September 1997), pp. 27-28; U.S. policy-The White House, Office of the Press Secretary, Nonproliferation and Export Control Policy Fact Sheet (Washington, DC, September 27, 1993). 


\section{Building the Inventories}

Large inventories of HEU and plutonium were built up for national defense purposes in the United States and Russia during some 40 years of production (Table 3 ). With the end of the cold war, the U.S. Government moved to declassify information about the sources and uses of its inventories of HEU and plutonium. As part of its "openness initiative" begun in 1993, DOE has made available through various media detailed information about the nuclear materials it manages. This chapter contains information released by DOE on inventories of commercial-grade uranium and other types of uranium produced from national defense programs.

In contrast to the United States, little official information is available regarding the sources, uses, and inventories of uranium, HEU, and plutonium in Russia. Historical analyses of nuclear programs have provided some insights into the current status of Russian inventories.
Oleg Bukharin at the Center for Energy and Environmental Studies at Princeton University, and David Albright, Frans Berkhout, and William Walker for the Stockholm International Peace Research Institute have published recent estimates of the sources and uses of Russian uranium and plutonium. The work of these authors serves as the basis for the following discussion on the inventories held by Russia. To develop estimates of inventories, the authors employed a combination of "bottom-up" and "top-down" approaches. For the bottom-up approach, estimates were made for the historical production capability at each step of the nuclear fuel cycle, including uranium mining, uranium enrichment, plutonium production, and recycling. The top-down approach consisted of (1) estimating the extent of nuclear programs for civilian and national defense purposes and (2) calculating the amount of uranium and plutonium required for each identified

Table 3. U.S. and Russian Production and Inventories of Highly Enriched Uranium (HEU) and Plutonium for National Defense Programs, December 31, 1993

\begin{tabular}{l|c|c|l}
\hline & $\begin{array}{c}\text { Production } \\
\text { (Metric Tons) }\end{array}$ & $\begin{array}{c}\text { Inventory } \\
\text { (Metric Tons) }\end{array}$ & \multicolumn{1}{c}{ Comments } \\
\hline Russian HEU & $1,400^{\mathrm{a}}$ & $1,270^{\mathrm{a}}$ & $\begin{array}{l}\text { Production ended in } 1988 . \\
\text { U.S. HEU }\end{array}$ \\
$\begin{array}{l}994^{\mathrm{b}} \\
\text { Russian Plutonium }\end{array}$ & $145^{\mathrm{a}}$ & $139^{\mathrm{a}}$ & $\begin{array}{l}\text { Production ended in 1992. } \\
\text { Ten out of 13 plutonium-production reactors were } \\
\text { closed between 1987 and 1992; production of } \\
\text { weapons-grade plutonium continues at 3 reactors } \\
\text { operated for electricity and heat generation. }\end{array}$ \\
& $103.4^{\mathrm{b}}$ & & \begin{tabular}{l} 
Production ended in 1988. \\
\hline
\end{tabular} \\
\hline
\end{tabular}

\footnotetext{
${ }^{a}$ Estimate.

b Published by the U.S. Department of Energy.

${ }^{c}$ As of September 1994, published by the U.S. Department of Energy. Inventory includes weapons-grade and non-weaponsgrade plutonium acquired from sources other than U.S. Government plutonium-production reactors.

Sources: Russian HEU-O. Bukharin, "Analysis of the Size and Quality of Uranium Inventories in Russia," paper presented at the Nuclear Energy Institute's International Uranium Fuel Seminar (Williamsburg, VA, October 8-11, 1995); U.S. HEU production-U.S. Department of Energy, Office of the Press Secretary, Openness Press Conference Fact Sheets (Washington, DC, June 27, 1994), p. 52; U.S. HEU inventories-D. Albright, F. Berkhout, and W. Walker, Plutonium and Highly Enriched Uranium 1996 World Inventories, Capabilities and Policies, Stockholm International Peace Research Institute (Oxford, United Kingdom, 1997), Table 4.3; Russian plutonium-D. Albright, F. Berkhout, and W. Walker, Plutonium and Highly Enriched Uranium 1996 World Inventories, Capabilities and Policies, Stockholm International Peace Research Institute (Oxford, United Kingdom, 1997), Table 3.12; U.S. plutonium -U.S. Department of Energy, Plutonium: The First 50 Years (Washington, DC, February 1996), Table 1.
} 
program. From the two approaches, an average or most likely value was selected from a range of estimates (Table 3).

\section{Russian Highly Enriched Uranium}

The Soviet Union produced an estimated 1,400 metric tons of HEU from 1950 until $1988 .^{28}$ This HEU is estimated to contain 90 percent ${ }^{235} \mathrm{U}$. Gaseous diffusion plants initially provided the enrichment. In the early 1960 's, however, centrifuge technology began to replace gaseous diffusion plants. The last gaseous diffusion plant was closed in 1991. Most of the uranium used in the production of HEU reportedly came from the reprocessing of fuel irradiated in plutonium-production reactors. As a result of the irradiation in reactors, the reprocessed uranium contained isotopic impurities, including ${ }^{234} \mathrm{U}$ and ${ }^{236} \mathrm{U}$. As discussed in the next chapter, the removal of these contaminants was required for LEU derived from Russian HEU to meet commercial specifications.

The inventory of HEU remaining in Russia was estimated to be 1,270 metric tons at the end of 1994 . Besides its use in weapons, HEU has been utilized as fuel for plutonium-production reactors, naval propulsion reactors, and research programs. HEU suitable for fueling naval propulsion reactors was apparently produced from higher assay HEU (90 percent ${ }^{235} \mathrm{U}$ ) irradiated in plutonium-production reactors and subsequently recovered through reprocessing.

\section{Russian Plutonium}

As estimated by Albright et al., the Soviet Union and Russia produced 145 metric tons of plutonium between 1949 and the end of 1993. ${ }^{29}$ By 1970, 13 plutoniumproduction reactors were in operation. All 13 reactors were of graphite-moderated, light-water cooled design; 5 were built at Chelyabinsk-65 in Mayak; 3 at
Krasnoyarsk-26 in Zheleznogorsk, near Krasnoyarsk; and 5 at Tomsk-7 in Sversk. Reprocessing facilities were also built at each location to recover plutonium and uranium from spent fuel discharged by the plutoniumproduction reactors. At the end of 1993, Russia held an estimated 131 metric tons of separated plutonium for national defense purposes. ${ }^{30}$

Ten Russian plutonium-production reactors were closed between 1987 and 1992. Despite undertaking the dismantling of nuclear weapons, Russia continues to operate two plutonium-production reactors at Tomsk-7 and one at Krasnoyarsk-26. Russian officials previously had stated that these facilities must continue to operate so that heat and electricity can be provided to the civilian population. Negotiations between the U.S. and Russian governments led to the announcement by Vice President Gore in September 1997 that Russia, with U.S. assistance, will end production of weapons-grade plutonium at the remaining three reactors. ${ }^{31}$ The core of each reactor will be converted to accommodate highburnup fuel. The reactors, scheduled to be converted by the end of 2001, will continue to provide needed electricity and heat but will no longer produce weaponsgrade plutonium..$^{32}$ Both countries also have agreed not to restart any plutonium-production reactors that have already been shut down.

Based on nonproliferation principles adopted by the Group of Seven Industrialized Nations and Russia in April 1996, Russia has developed plans to burn surplus plutonium in civilian light-water and fast breeder reactors. These plans include a joint venture between MINATOM and two Western nuclear fuel companies, Cogema and Siemens, to build and operate a MOX fuel plant that will use weapons-grade plutonium. ${ }^{33}$ The plant, named DEMOX, is expected to fabricate 1.3 metric tons of MOX fuel per year by early in the next decade.

Unlike the uranium made available to the world market from the conversion of Russian HEU, Russian plutonium is not expected to be consumed outside Russia except under possible bilateral agreements. ${ }^{34}$ The utilization of

${ }^{28}$ O. Bukharin, "Analysis of the Size and Quality of Uranium Inventories in Russia," paper presented at the Nuclear Energy Institute's International Uranium Fuel Seminar (Williamsburg, VA, October 8-11, 1995).

${ }^{29}$ D. Albright, F. Berkhout, and W. Walker, Plutonium and Highly Enriched Uranium 1996 World Inventories, Capabilities, and Policies, Stockholm International Peace Research Institute (Oxford, United Kingdom, 1997), Table 3.12.

${ }^{30}$ Ibid.

${ }^{31}$ Announcement at the ninth session of the U.S.-Russian (Gore-Chemomydrin) Joint Commission on Economic and Technological Cooperation (Moscow, September 23, 1997).

${ }^{32}$ B. Kremer, personal communication, U.S. Department of Energy, Office of Nuclear Energy, Science and Technology (Washington, DC, November 20, 1997).

${ }^{33}$ Cogema, MOX Plant in Russia: The Engineering Work Has Started (Velizy Cedex, France, September 1997), pp. 1-5.

${ }^{34}$ The Government of Canada has offered the use of CANDU reactors in Canada to bum surplus weapons-grade plutonium. 
MOX fuel has no impact on Russian purchases of imports, because all requirements for commercial nuclear fuel are filled by internal supplies. For these reasons, Russian surplus plutonium inventories are not included in the analysis of government inventories presented in this report.

\section{U.S. Highly Enriched Uranium}

The U.S. Government produced 994 metric tons of HEU from 1945 to $1992 .{ }^{35}$ This production came from two gaseous diffusion plants operated by DOE and its predecessor organizations: the K-25 site in Oak Ridge, Tennessee, from 1945 until 1964, and the Portsmouth plant in Portsmouth, Ohio from 1956 until 1992.36 A third gaseous diffusion plant, the Paducah plant near Paducah, Kentucky, began to operate in 1954 as a source of LEU feedstock used in producing HEU at the other two plants. All three plants also provided enrichment services for uranium to fuel commercial nuclear power plants. The K-25 site was placed on standby in 1985 and subsequently closed in 1987. The Portsmouth and Paducah plants continue to serve commercial customers. In addition to the gaseous diffusion plants, "other technologies" were used in producing unspecified "small" quantities of HEU prior to 1947. ${ }^{37}$

The production of HEU in the United States for use specifically in nuclear weapons was terminated in 1964. However, HEU with a ${ }^{235} \mathrm{U}$ content between 20 percent and 90 percent was produced until 1992 to fuel U.S. Navy propulsion reactors and for research purposes. A full accounting of U.S. HEU inventories has not been made available by the U.S. Government. Albright et al. estimated that 749 metric tons of HEU were held by the United States at the end of $1993 .^{38}$

As part of its Openness Policy, DOE expects to complete a report in which it will detail the U.S. Government's production, acquisition, uses, inventories, and disposition of HEU from 1945 through 1996. ${ }^{39}$
Besides material currently being used by the Department of Defense, DOE holds HEU that has been returned to inventory after use in certain applications, as well as raw materials that have not yet been used. Returns to inventory have come principally from the ongoing dismantling of nuclear weapons and from reactor fuels that were originally supplied by the United States to foreign countries and subsequently returned. In August 1996, an environmental, safety, and health assessment was completed for over 250 metric tons of HEU stored at 22 DOE sites. This material includes pits and other disassembled nuclear weapons parts, metals, oxides, process residues, solutions, and reactor fuel. ${ }^{40}$

\section{U.S. Plutonium}

In February 1996, the Secretary of Energy released a comprehensive accounting of the U.S. Government's sources and uses of plutonium . ${ }^{41}$ The United States has produced or acquired 111.4 metric tons of plutonium between 1944 and 1994. Fourteen plutonium-production reactors at Hanford, Washington, and at the Savannah River site near Aiken, South Carolina, were operated by the U.S. Government between 1944 and 1988. These reactors produced 103.4 metric tons of plutonium. The remaining sources were U.S. Government nonproduction reactors ( 0.6 metric ton), foreign countries (5.7 metric tons), and the U.S. civilian nuclear industry (1.7 metric tons). As of September 1994, 99.5 metric tons of plutonium remained in inventory. Plutonium withdrawals include materials used in wartime, testing, transfers to the U.S. civilian industry and foreign countries, and losses due to radioactive decay.

In 1944, the B-Reactor at Hanford became the first plutonium-production reactor to operate in the United States. Eight other reactors, all of graphite-moderated, light-water-cooled design, commenced operation at Hanford between 1944 and 1963. Before the last reactor was closed in 1987, Hanford produced 54.5 metric tons of weapons-grade plutonium and 12.9 metric tons of

\footnotetext{
${ }^{35}$ U.S. Department of Energy, Office of the Press Secretary, Openness Press Conference Fact Sheets (Washington, DC, June 27, 1994 ), p. 52.

${ }^{36}$ Prior to the establishment of DOE, U.S. enrichment activities were administered by the Atomic Energy Commission (1946-1975) and the Energy Research and Development Administration (1975-1977).

${ }^{37}$ U.S. Department of Energy, Office of the Press Secretary, Openness Press Conference Fact Sheets (Washington, DC, June 27, 1994), p. 52.

${ }^{38}$ D. Albright, F. Berkhout, and W. Walker, Plutonium and Highly Enriched Uranium 1996 World Inventories, Capabilities, and Policies, Stockholm International Peace Research Institute (Oxford, United Kingdom, 1997), Table 3.12.

${ }^{39}$ U.S. Department of Energy, Office of the Press Secretary, Openness: The Way to Do Business Press Conference Fact Sheets (Washington, DC, January 15, 1997), p. 51.

${ }^{40}$ U.S. Department of Energy, Highly Enriched Uranium Working Group Report on Environmental, Safety and Health Vulnerabilities Associated with the Department's Storage of Highly Enriched Uranium, DOE/EH-0525 (Washington, DC, December 1996), p. 1.

${ }^{41}$ U.S. Department of Energy, Plutonium: The First 50 Years (Washington, DC, February 1996), 82 pp.
} 
fuel-grade plutonium. Five production reactors were built at the Savannah River site between 1953 and 1955. They were designed to use heavy water as both a moderator and the primary cooling medium. Savannah River had produced 36.1 metric tons of weapons-grade plutonium until production ended in 1988. Although plutonium production ceased in 1988, one reactor at Savannah River, the K-Reactor, had been maintained as a near-term contingency for tritium production..$^{42}$ With plans to develop new sources of tritium, DOE permanently closed the K-Reactor in $1996 .{ }^{43,44}$

Government nonproduction reactors were operated for purposes other than producing plutonium. These reactors were used for test and research activities, power production, and naval propulsion. Several DOE-owned prototype reactors operated by public utilities were also included in this category. Government nonproduction reactors produced 0.1 metric ton of weapons-grade plutonium and 0.5 metric ton of fuel-grade plutonium.

The U.S. Government acquired plutonium from the U.S. civilian nuclear industry through the Plutonium Credit Activity program and other agreements to take back spent fuel or other materials. In 1983, legislation was passed restricting the use of plutonium acquired from U.S. civilian sources to non-weapons purposes. The Plutonium Credit Activity, established by the Atomic Energy Act of 1954, as amended, provided credits to commercial utilities that returned spent fuel to the AEC. Even though the AEC owned all uranium that fueled commercial nuclear power reactors until private ownership was allowed in 1964, the plutonium that was produced during the operation of the reactors was owned by the utilities. Interestingly, the Atomic Energy Act of 1946, which prohibited private ownership of uranium, did not pertain to the back end of the fuel cycle.

Between 1957 and 1970, five utilities were paid $\$ 10.4$ million for approximately 0.9 metric ton of fuel-grade plutonium under the Plutonium Credit Activity. None of the plutonium reprocessed from the U.S. civil nuclear industry was used to produce weapons. ${ }^{45}$ In addition to the Plutonium Credit Activity, approximately 0.8 metric ton of fuel-grade plutonium was acquired as spent fuel from commercial reactors and as special fuels and materials from universities, hospitals, and private industry. Most of this material was acquired by the U.S. Government for purposes of storage and eventual disposal.

Approximately 5.7 metric tons of plutonium were acquired from 15 foreign countries. The largest share, 5.4 metric tons, came from the United Kingdom; it was acquired from 1959 to 1980 under the Mutual Defense Agreement between the United States and the United Kingdom. In exchange, the United States provided the United Kingdom with tritium and HEU. The remainder of the plutonium was acquired through Agreements for Cooperation with the International Atomic Energy Agency, the European Atomic Energy community, and bilateral agreements with various countries. The Agreements for Cooperation involved programs engaged in the peaceful uses of atomic energy. Most of this plutonium was contained in spent fuel.

Plutonium, along with uranium, was recovered through the reprocessing of spent fuel and other irradiated targets produced by U.S. Government production reactors or acquired by the Government from other sources. Reprocessing took place at three U.S. Government-owned sites and one privately owned site. U.S. Government-owned plutonium recovery facilities, called "canyons," were operated at Hanford, Savannah River, and Idaho National Engineering Laboratory. In April 1992, DOE announced the phaseout and eventual end of U.S. Government reprocessing due to declining demand for plutonium and HEU.

Nuclear Fuel Services operated a reprocessing plant at West Valley, New York, from 1965 until 1972; it was the only privately owned reprocessing facility operated in the United States. The West Valley plant reprocessed most of the 0.9 metric ton of plutonium acquired by the U.S. Government from utilities through the Plutonium Credit Activity. ${ }^{46}$ Also, approximately 0.6 metric ton of plutonium was recovered at West Valley from AECowned spent fuel and liquid residues. The separated plutonium was shipped as plutonium nitrate solution by commercial truck to Hanford. In 1972, Nuclear Fuel Services suspended operation for the purposes of

\footnotetext{
${ }^{42}$ Ibid, p. 30.

43 U.S. Department of Energy, Office of Defense Programs, Decision to close K-Reactor (February 1996).

44 The Department of Energy (DOE) is evaluating two potential production options for producing tritium: (1) existing commercial lightwater reactors and (2) an accelerator system designed and built by DOE.

${ }^{45}$ U.S. Department of Energy, Plutonium Recovery from Spent Fuel Reprocessing by Nuclear Fuel Services at West Valley, New York from 1996 to 1972 (Washington, DC, February 1996), p. 13.

${ }^{46}$ Ibid, p. 1.
} 
increasing capacity and to retrofit the plant to meet new regulatory requirements. After failure to meet the new requirements, all reprocessing activities at West Valley were terminated.

\section{U.S. Government Commercial-Grade Uranium}

At the end of 1996, the U.S. Government, through DOE and the United States Enrichment Corporation (USEC), held inventories of natural $\mathrm{UF}_{6}$ and LEU equivalent to 107.7 million pounds $\mathrm{U}_{3} \mathrm{O}_{8}{ }^{47}$ The natural UF ${ }_{6}$ and LEU contained in these inventories are referred to as "commercial-grade" because they can be sold directly in the commercial nuclear fuel market. Although owned by the U.S. Government, USEC is operated as a commercial corporation that is involved in the commercial nuclear fuel cycle (see text box, page 23). Its inventories are considered to be an integral part of its business, rather than surplus to its needs. Therefore, USEC's inventories are not considered in the scope of this report.

The total quantity of DOE's inventories of commercialgrade uranium held for defense purposes has not been disclosed. However, DOE recently announced plans, described in Chapter 5, for commercializing about 40 million pounds $\mathrm{U}_{3} \mathrm{O}_{8}$ equivalent declared as surplus that was originally intended for use in U.S. defense programs. This inventory consists principally of natural $\mathrm{UF}_{6}$ and a lesser amount of LEU. Pending transfers of DOE inventories to USEC are considered in this report as part of various DOE disposition programs.

\section{Other U.S. Government Inventories of Uranium}

DOE also holds other inventories of uranium that do not fit in the categories previously described. These inventories are characterized as: (1) surplus natural and slightly enriched uranium and (2) depleted uranium contained in enrichment tails. ${ }^{48}$ The uranium contained in these inventories would require additional processing before being used to produce nuclear fuel.

The surplus natural and slightly enriched uranium is contained in various forms, including metals, oxides, and other compounds, not readily amenable for commercial use. ${ }^{49}$ While assaying between 0.71 and 1.25 percent ${ }^{235} \mathrm{U}$, much of the uranium contains impurities that does not allow it to meet specifications of the American Society for Testing and Materials (ASTM) for nuclear fuel. DOE, through its field offices, proposed to sell uranium that does meet ASTM specifications in fiscal year 1997, although previous attempts to sell it to a domestic buyer were unsuccessful. Without the strong nonproliferation incentives attached to HEU and plutonium, DOE is not likely to process this material into marketable form before finding a commercial buyer. Recently, DOE proposed to use surplus slightly enriched uranium stored at the Fernald, Ohio field office for blending down HEU that would be utilized by the Tennessee Valley Authority (see page 34)..$^{50}$

Approximately 560,000 metric tons of enrichment tails are stored at the Paducah, Portsmouth, and K-25 enrichment plant sites. ${ }^{51}$ These tails, containing depleted uranium, were produced during the enrichment of uranium for both civilian and military purposes prior to DOE's transfer of enrichment activities to USEC on July 1, 1993. Unlike Russia, the United States does not recycle enrichment tails. Because of the high electricity costs associated with the operation of U.S. gaseous diffusion plants, the enrichment of tails is not economically feasible in the United States under current uranium market conditions. Meanwhile, DOE is currently preparing an environmental impact statement that addresses various storage alternatives, including retrieval for future use. ${ }^{52}$ Because no final determination has been reached, an analysis of the potential effects of U.S. enrichment tails on the nuclear fuel market is not undertaken in this report.

\footnotetext{
${ }^{47}$ Energy Information Administration, Uranium Industry Annual 1996, DOE/EIA-0478(96) (Washington, DC, April 1997$)$, Table 31.

48 The term "slightly enriched uranium" is used to describe enriched uranium having a ${ }^{235} \mathrm{U}$ content lower than required for commercial reactor fuel.

${ }^{49}$ U.S. Department of Energy, Office of the Secretary, Determination Pursuant to the United States Enrichment Corporation Privatization Act for the Sale of Excess Department of Energy Uranium During Fiscal Year 1997 (Washington, DC, March 12, 1997).

${ }^{50}$ R. Schmidt, personal communication (HEU Disposition Program Office, Oak Ridge, TN, March 3, 1998).

51 U.S. Department of Energy, Office of Nuclear Energy, Science and Technology, Draft Programmatic Environmental Statement on Alternative Strategies for the Long-term Management and Use of Depleted Uranium Hexafluoride (Summary), DOE/EIA-EIS-0269 (Washington, DC, December 1997).

52 Ibid.
} 


\section{Sale of Highly Enriched Uranium from Dismantled Russian Nuclear Weapons}

\section{From Concept to Agreement}

Russian HEU became the world's first uranium from dismantled nuclear weapons to be converted into fuel for civilian nuclear power plants. This historic development, popularly referred to as "megatons to megawatts," came about as the United States and Russia resolved a series of political, economic, and technical issues over the course of 4 years (Appendix A, Table A1). As a result, the uranium that once was contained in the nuclear weapons of a former adversary is now being used to generate electricity for homes and businesses in the United States.

The weapons-to-fuel concept was advanced by the United States in 1991 to address proliferation concerns related to the growing inventories of surplus HEU and plutonium derived from dismantled Soviet nuclear weapons. These concerns escalated with the dissolution of the Soviet Union in late 1991. While most of the former Soviet Union's nuclear industry came under the control of Russia, political changes and a deterioration of economic conditions made it difficult to ensure adequate security for nuclear materials. From the Russian government's stand point, the surplus HEU was an important national asset that could be used to secure foreign exchange. With strong incentives for both parties to reach an agreement, President Bush announced in August 1992 that the United States and Russia had agreed in principle for the United States to purchase Russian HEU for conversion into commercial nuclear fuel.

In anticipation of the final agreement between the two countries, the Energy Policy Act of 1992 (EPACT), signed into law in October 1992, provided the legal framework for the United States to implement the purchase of Russian HEU. EPACT authorized the newly established United States Enrichment Corporation (USEC) to "negotiate the purchase of all highly enriched uranium made available by any state of the former Soviet Union under a government-to-government agreement." 53 However, USEC's enabling legislation contained certain provisions that could potentially conflict with objectives of securing Russian HEU. As the U.S. Executive Agent for the purchase of Russian HEU, USEC was directed to minimize the impact on the U.S. uranium industries of the sale on the commercial market of LEU derived from Russian HEU. In addition, EPACT authorized USEC to "operate as a business enterprise on a profitable and efficient basis" and to "maximize the long-term value of the Corporation to the Treasury of the United States, as well as to be the beneficiary of transfers from DOE of surplus inventories of U.S. HEU and natural uranium. ${ }^{, 54}$

On February 18, 1993, a little over a year after the breakup of the Soviet Union, a formal agreement was signed as The Agreement between the Government of the United States and the Government of the Russian Federation Concerning the Disposition of Highly Enriched Uranium Extracted from Nuclear Weapons. This agreement, referred to hereafter in this report as the Russian HEU Agreement, provided for the United States to purchase 500 metric tons of HEU over 20 years. The HEU was to come specifically from the dismantling of Russian nuclear weapons. The dismantling of weapons, the separation of HEU from warheads, and the blending down of HEU to produce LEU suitable for use as fuel in nuclear power plants would be carried out in Russia. The agreement called for USEC to purchase the LEU derived from 10 metric tons of HEU annually in the first 5 years of the agreement, increasing to 30 metric tons in later years. Prices and timing of deliveries would be negotiated annually. Over the life of the agreement, the United States would pay Russia about $\$ 11.9$ billion (in 1993 dollars) for 15,259 metric tons of LEU, which would displace about 398 million pounds $\mathrm{U}_{3} \mathrm{O}_{8}$ of mined uranium and 92 million SWU of enrichment that would be needed to produce an equivalent amount of LEU. ${ }^{55}$

${ }^{53}$ Energy Policy Act of 1992, Title II-The United States Enrichment Corporation (Chapter 24, Section 1408).

${ }^{54}$ Ibid; Chapter 22, Section 1202.

${ }^{55}$ Assumes an LEU product assay of 4.4 percent U-235 derived from HEU feedstock containing 90 percent U-235 and a slightly enriched uranium blendstock containing 1.5 percent U-235. 


\section{United States Enrichment Corporation}

USEC was created by the Energy Policy Act of 1992 (EPACT) as an initial step in transferring to the private sector the uranium enrichment activities formerly held by the U.S. Department of Energy (DOE). As a wholly owned Government corporation, all of USEC's stock issued and outstanding is held by the U.S. Treasury. Similarly, all net revenues not required for operating expenses, investments, or working capital are required to be paid as dividends to the U.S. Treasury. However, USEC's enabling legislation intended that it be operated as a market-oriented business, without many of the constraints faced by Government agencies, while preparing for privatization.

USEC began operating as a business on July 1, 1993. It manages the operation of gaseous diffusion plants for uranium enrichment in Paducah, Kentucky, and Portsmouth, Ohio. Both plants are leased from DOE. For the fiscal year ending June 30,1997 , USEC reported revenues of about $\$ 1.6$ billion from sales of enrichment services to electric utilities in 14 countries, including the United States. Net income for the year was around $\$ 250$ million. As a U.S. Government corporation, USEC is exempt from Federal, State, and local taxes.

USEC is also demonstrating the commercial application of the Atomic Vapor Laser Isotope Separation (AVLIS) technology for uranium enrichment. The ownership of AVLIS had been transferred from DOE to USEC pursuant to EPACT. AVLIS differs from the gaseous diffusion and centrifuge technologies that are currently being operated. It utilizes uranium metal, rather than gaseous $\mathrm{UF}_{6}$, as the feedstock for enrichment. USEC expects to operate AVLIS commercially in 2004.

Pursuant to EPACT, USEC's Board of Directors submitted its privatization plan to Congress and President Clinton in June 1995. The privatization plan recommends a "dual-path approach," whereby a negotiated sale to private investors is pursued simultaneously with an initial public offering of common stock. However, privatization will depend on meeting several criteria, including the maintenance of a reliable domestic supply of enrichment service and securing the maximum financial return to the U.S. Government. The United States Enrichment Corporation Privatization Act, signed in April 1996, provides for certain restrictions on privatization. For example, no one person may own more than 10 percent of the corporation within 3 years of privatization. USEC's Board of Directors is authorized to select the final terms of the sale as well as the purchaser. The Secretary of Treasury is also required to approve the terms of the sale. On July 25, 1997, President Clinton approved the initiation of privatization. This approval directs USEC to work with the Treasury Department, Nuclear Regulatory Commission, and other relevant Government agencies to implement the final privatization transaction.

Sources: United States Enrichment Corporation, 1996 Annual Report, Energy Policy Act of 1992; USEC Privatization Act, and United States Enrichment Corporation, press releases (August 8,1997 and October 23, 1997).

\section{Delays in Implementing the Russian HEU Agreement}

The Russian HEU Agreement authorized the Executive Agents, USEC and Techsnabexport Company Ltd. (TENEX), to conclude implementation contracts within 6 months after the signing of the agreement. ${ }^{56}$ Three concerns had to be addressed before the Russian HEU Agreement could be implemented. They were: (1) LEU derived from $\mathrm{HEU}$ did not meet product standards for commercial nuclear fuel; (2) verification was required that HEU was derived from dismantled nuclear weapons; and (3) Russia was to be paid in a timely fashion for the natural uranium component of the LEU derived from blending down the HEU.

The LEU derived from Russian HEU did not initially meet the specifications established by the American Society for Testing and Materials for commercial nuclear fuel. It was contaminated with unacceptable plutonium and high quantities of ${ }^{234} \mathrm{U}$ and ${ }^{236} \mathrm{U}$ isotopes. These contaminants would interfere with the fission of uranium atoms required to produce energy for generating electricity. The problem was resolved in two steps. ${ }^{57}$ First, a reprocessing circuit was dedicated at

\footnotetext{
${ }^{56}$ Techsnabexport is a joint stock company responsible for exporting uranium held by the Ministry of Atomic Energy for the Russian Federation.

${ }^{57}$ The Ux Consulting Company, LLC, Analysis of World Nuclear Fuel Inventories (Marietta, GA, April 1997 ), p. 5.
} 
Tomsk-7 for the purification of the HEU. In this process, plutonium is chemically separated from the HEU. In the second step, the purified HEU was blended with slightly enriched tails containing relatively low concentrations of ${ }^{234} \mathrm{U}$ and ${ }^{236} \mathrm{U}$. The resulting LEU was able to meet the required specifications.

The United States required verification that the LEU it purchased under the Russian HEU Agreement had been converted from HEU taken from dismantled nuclear weapons. This issue is referred to as "transparency," because the Russian dismantlement and conversion activities had to be sufficiently transparent to be verified with a high degree of confidence. An agreement was signed between the United States and Russia in March 1994 that established a mutually acceptable framework for resolving the transparency issue, but the implementation of the agreement required further negotiations. Implementation involved monitoring at facilities regarded by the Russians as sensitive with regard to national security. On-site inspections of each country's weapons dismantlement facilities and remote monitors have been proposed as a means to meet the objectives of transparency.

LEU produced from Russian HEU contains uranium from HEU feedstock and slightly enriched blendstock. To produce each stock, uranium had to be converted and enriched. Thus, the LEU has an asset value equal to the sum of its contained costs for $\mathrm{U}_{3} \mathrm{O}_{8}$, conversion, and SWU. The terms of the initial Russian HEU Agreement provided for USEC to pay for the contained SWU when the LEU was delivered by Russia. However, USEC agreed to pay Russia for the enrichment contained in the LEU at a price higher than its marginal cost of production..$^{58}$ USEC would pay for the natural uranium feed component of the LEU, made up of the cost of $\mathrm{U}_{3} \mathrm{O}_{8}$ and conversion, only after the natural uranium feed was either sold or used for "overfeeding" the enrichment plants. ${ }^{59}$ USEC secures the natural uranium feed by substituting LEU purchased from Russia for the natural $\mathrm{UF}_{6}$ normally delivered by utilities as enrichment feed material (see box, page 20). Because of this substitution, USEC charges utilities only for the SWU contained in the LEU.

The natural uranium feed component of Russian LEU is referred to in this report as "Russian feed." It must be noted that Russian feed includes the equivalent $\mathrm{U}_{3} \mathrm{O}_{8}$ and conversion contained in both the slightly enriched blendstock and the HEU feedstock used to produce the LEU. Because USEC had not sold or used internally any Russian feed, it made no payments to Russia for the natural uranium feed component. As a result, the Russian Executive Agent moved to delay implementing the second year of the contract. USEC then paid $\$ 161$ million (in 1996 dollars) for Russian feed contained in the LEU derived from 18 metric tons of HEU purchased in 1995 and $1996 .{ }^{60}$ This action allowed the U.S. and Russian Executive Agents to implement the contract.

\section{First Deliveries of Low-Enriched Uranium Derived from Russian HEU}

The first delivery to the United States of LEU blended down from Russian HEU arrived by ship in Baltimore in June 1995. It was transported to the Portsmouth plant, where it was made available by USEC to fill commercial contracts. (USEC has no restrictions on the quantity of SWU contained in the LEU it can sell.) The first sale of LEU derived from Russian HEU for use as fuel in a commercial nuclear reactor occurred in November 1995, when USEC delivered a quantity of Russian LEU to fill a contract for enrichment with a U.S. utility.

Because of the problems described above, only 6 metric tons of HEU were downblended to LEU by Russia for delivery to USEC in 1995. The quantity of HEU was 60 percent of the 10 metric tons specified by the Russian HEU Agreement. In 1996, Russia increased deliveries of LEU to the equivalent of 12 metric tons of HEU. As described below, annual deliveries for 1997 and 1998 were rescheduled to substantially exceed the 10 metric tons specified in the initial contract.

\section{Authorization for the Sale of the Russian Uranium Feed Component}

The USEC Privatization Act, signed into public law in April 1996, provided the legal framework for USEC to address the Russian feed issue. It also regulated the quantity of $\mathrm{U}_{3} \mathrm{O}_{8}$ contained in Russian feed that can enter

\footnotetext{
${ }^{58}$ D. Collier, "HEU-Can the Industry Adapt?" in Focus-Nuclear Fuel Cycle Quarterly, NAC International (Norcross, GA, Spring 1997), p. 8.

${ }^{59}$ Overfeeding is the use of more relatively less expensive uranium to produce the same quantity of enriched product with less relatively more expensive power. In this process, the actual enrichment tails assay would be higher than the contracted tails assay.

${ }^{60}$ United States Enrichment Corporation, 1996 Annual Report, p. 25.
} 


\section{Concept of Separating the Natural Uranium Feed Component from Russian Low-Enriched Uranium (LEU) Delivered to the United States Enrichment Corporation (USEC)}

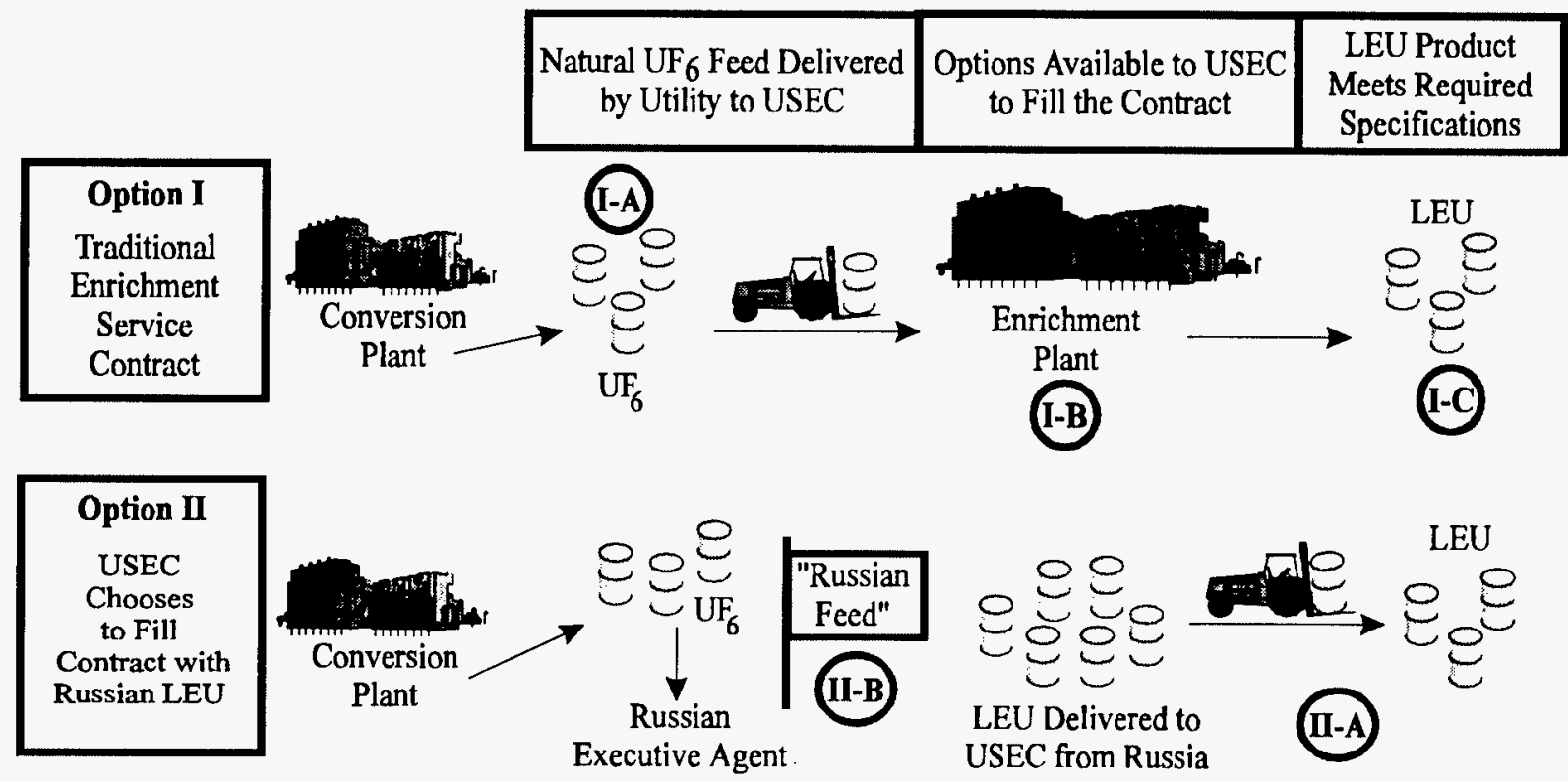

Option I: A utility contract for enrichment services is filled by traditional means (no Russian LEU involved). Utilityowned natural uranium hexafluoride $\left(\mathrm{UF}_{6}\right)$ is delivered to USEC from the conversion plant; ${ }^{\mathrm{a}}$ the amount delivered corresponds to the quantity of natural uranium feed required to meet the specifications of the contract. The material is held as inventory (I-A) until the actual enrichment service takes place (I-B). The resulting LEU produced by USEC (I-C) meets the specifications of the contract.

Option II: USEC chooses to fill the contract with LEU delivered from the Russian Federation (II-A) rather than by feeding its enrichment plant with natural $\mathrm{UF}_{6}$ delivered by the utility. The contract to deliver LEU to USEC is based on the Russian HEU Agreement; ${ }^{b}$ the LEU is derived from blending down highly enriched uranium (HEU) taken from dismantled Russian nuclear weapons. Since USEC is paying Russia for only the enrichment services component of the LEU, the equivalent natural uranium feed component is required by the USEC Privatization Act to be returned to the Russian Executive Agent or sold on behalf of the Russian Executive Agent. ${ }^{c}$ Actual quantities of the natural feed component are made available by substituting the LEU received from Russia for the equivalent natural uranium feed and the cost of enrichment services that would have been required if USEC had produced the required enrichment services. The customer-supplied natural uranium feed displaced by the Russian LEU is subsequently labeled "Russian feed." This uranium is to be sold separately so that Russia can be paid for the natural uranium feed component of Russian LEU delivered to USEC. As illustrated above (II-B), the natural UF feed delivered to USEC by the utility for enrichment is designated as Russian feed.

aConversion is the process of changing natural uranium oxide $\left(\mathrm{U}_{3} \mathrm{O}_{8}\right)$ from the milling or processing of uranium ore into uranium hexafluoride $\left(\mathrm{UF}_{6}\right)$, the feedstock required for enriching naturally occurring uranium into fuel for nuclear power plants.

${ }^{\mathrm{b}}$ The Agreement between the Government of the United States and the Government of the Russian Federation Concerning the Disposition of Highly Enriched Uranium Extracted from Nuclear Weapons (February 18, 1993).

'USEC Privatization Act (April 26, 1996), Section 3112(b).

Source: Energy Information Administration, Office of Coal, Nuclear, Electric and Alternate Fuels. 
the U.S. market. ${ }^{61}$ For deliveries of Russian LEU made on or after January 1,1997, USEC is directed to concurrently make available to the Russian Executive Agent the quantity of natural $\mathrm{UF}_{6}$ contained in the Russian feed. The Russian Executive Agent could direct USEC to deliver the Russian feed to a North American facility of its choice. Thus, the Russian Executive Agent will gain immediate access to the feed component, and it may then offer for sale the contained $\mathrm{U}_{3} \mathrm{O}_{8}$ and conversion services. In return, USEC will be responsible for purchasing only the SWU component.

The Russian feed is considered "Russian-origin uranium." Russia has no restrictions on selling the conversion component of the Russian feed it receives from USEC. However, the $\mathrm{U}_{3} \mathrm{O}_{8}$ component of the feed can only be sold to U.S. end users either as matched sales established by an amendment to the Suspension Agreement with Russia (see textbox, p. 22) or by an annual direct quota authorized by the USEC Privatization Act (Table 4). The direct quota applies to the feed component of Russian LEU delivered to USEC on or after January 1, 1997. Russian feed sold through matched sales transactions cannot be counted against the direct quota. The $\mathrm{U}_{3} \mathrm{O}_{8}$ component can be sold outside the United States at any time.

For deliveries of Russian LEU made in 1995 and 1996, the USEC Privatization Act directed USEC to transfer without cost the Russian feed to DOE. DOE was made

Table 4. U.S. Restrictions on Selling the Uranium Feed Component of Low-Enriched Uranium (LEU) Produced from Blending Down Russian Highly Enriched Uranium (HEU) After January 1, 1997

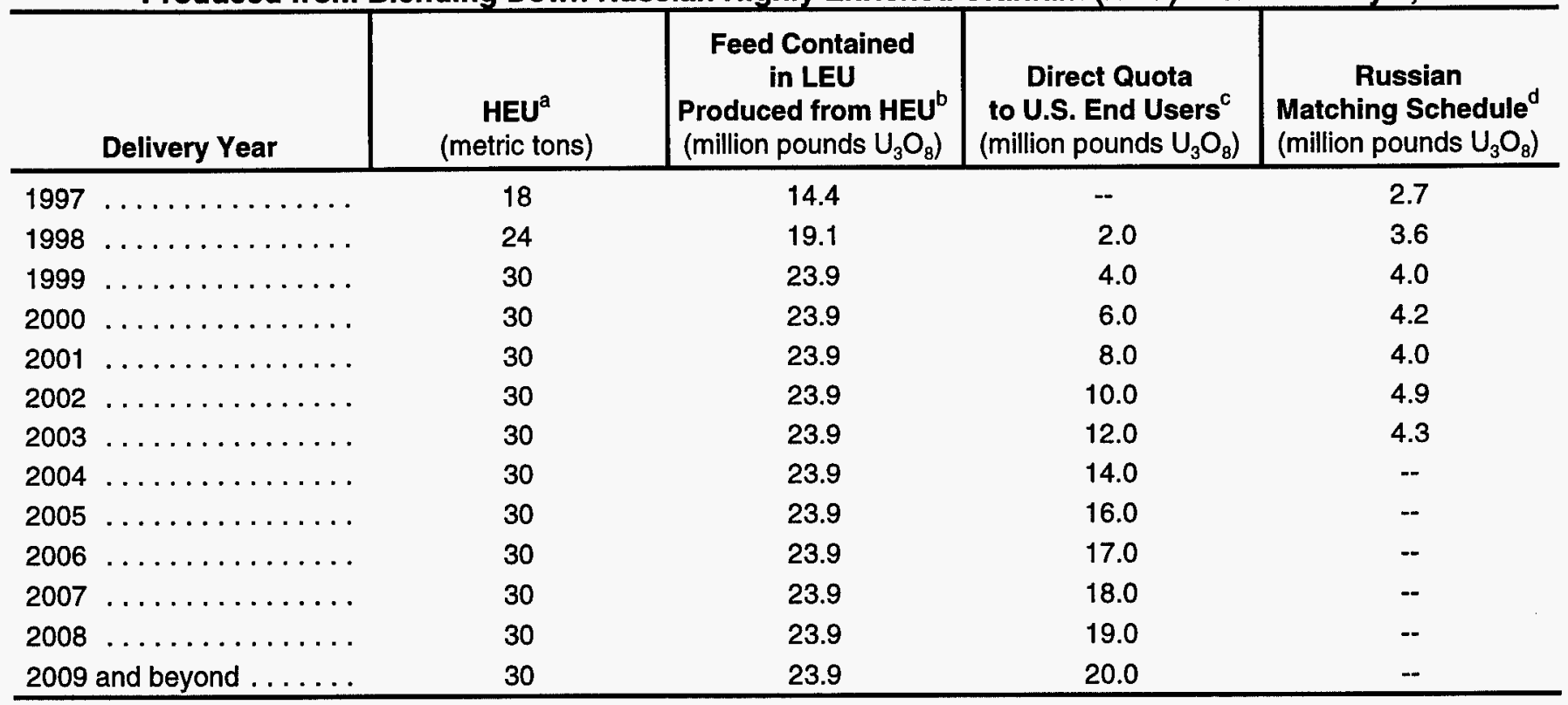

a Likely capacity for blending Russian HEU down to low-enriched uranium; the quantity for 1997-2001 pursuant to an agreement between the U.S. Enrichment Corporation and Teclisnabexport, November 1996. For 2002 and later years, it is assumed that 30 metric tons of $\mathrm{HEU}$ will be blended down to LEU.

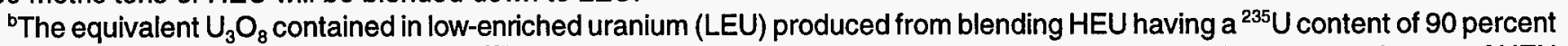
with slightly enriched uranium having a ${ }^{235} \mathrm{U}$ content of 1.5 percent. For example, the LEU produced from 18 metric tons of HEU would contain the equivalent of 14.4 million pounds $\mathrm{U}_{3} \mathrm{O}_{8}$ in the following combination: 10.3 million pounds in the HEU feedstock and 4.1 million pounds in the slightly enriched uranium blendstock.

CPursuant to the USEC Privatization Act (April 26, 1996), Section 3112(b).

${ }^{d}$ The Amendment to the Suspension Agreement with the Russian Federation (March 11, 1994) provides for a schedule whereby Russia can sell uranium at specified quantities to U.S. end users as long as the sales are matched with newly produced U.S.origin uranium.

Sources: Quota and schedule-See footnotes $\mathrm{c}$ and d; Uranium feed contained in LEU-Energy Resources International, Inc., 1997 Nuclear Fuel Cycle Supply and Price Report (Washington, DC, May 1997), Table 4-18.

${ }^{61}$ Public Law 104-134, Balanced Budget Down Payment Act, Subchapter A-USEC Privatization Act, Section 3112b (Uranium Transfers and Sales-Russian HEU) (April 26, 1996). 
responsible for selling and receiving payment for this uranium within 7 years of the enactment of the USEC Privatization Act (signed April 1996). DOE is permitted to sell the Russian feed under the following conditions: (a) at any time for use in the United States for the purpose of overfeeding; (b) at any time for end use outside the United States; (C) to the Russian Executive Agent in 1995 and 1996 for use in matched sales pursuant to the amendment to the Suspension Agreement with Russia; or (d) in calendar year 2001 for consumption by end users in the United States not prior to January 1,2002 , in volumes not exceeding 3 million pounds $\mathrm{U}_{3} \mathrm{O}_{8}$ equivalent per year.

\section{Current Status}

\section{Russian HEU Agreement}

The Russian HEU Agreement currently reflects a series of agreements concluded between USEC and TENEX during the second half of 1996 (Appendix A, Table A1).

\section{Suspension Agreement With Russia}

Beginning in the late 1980s, the Soviet Union sold significant quantities of natural and enriched uranium to the Western world. The large quantity of these sales, estimated to be as much as 246 million pounds $\mathrm{U}_{3} \mathrm{O}_{8}$ equivalent through 1996, served to depress market prices. In response, a coalition of 13 domestic uranium producers and the Oil, Chemical and Atomic Workers Union, representing employees at DOE's enrichment plants, filed an antidumping petition with the U.S. Department of Commerce (DOC) and the International Trade Commission (ITC) in November 1991. The petition alleged that imports from the former Soviet Union were priced below fair value, thus causing injury to the U.S. uranium industry. Subsequently, the DOC and the ITC ruled that the domestic industry had been injured by such imports. In October 1992, DOC signed agreements with six republics of the former Soviet Union, including Russia, whereby imports from the republics would be restricted in exchange for DOC suspension of its antidumping investigations." The Agreement Suspending the Antidumping Investigation on Uranium from the Russian Federation (Suspension Agreement with Russia) allowed a certain quantity of Russian imports to enter the United States as long as the actual market price was above a threshold price determined by DOC. Since uranium market prices remained low, no new purchases of Russian uranium could be made for consumption in the United States. ${ }^{\text {b }}$

Moving to implement a more realistic quota system, the DOC and MINATOM signed an amendment to the Suspension Agreement in March 1994. The amended agreement covers the period from April 1, 1994, through March 31,2004 . It replaces the previous price-based quotas with set annual quotas. In order to exercise the quota, Russian imports must be matched with a corresponding volume of newly produced U.S. uranium or SWU. Contracts must also be matched in duration (i.e., spot or long-term) and product type (i.e., $\mathrm{U}_{3} \mathrm{O}_{8}$ or enriched uranium). No one company can purchase more than 20 percent of any year's quota. The quota established for $\mathrm{U}_{3} \mathrm{O}_{8}$ varies annually between 1.9 million pounds and 6.6 million pounds $U_{3} \mathrm{O}_{8}$. The annual quota established for enrichment was 2 million SWU. However, to account for the lack of restrictions on the sale of the SWU component of LEU derived from Russian HEU, imports of Russian-origin SWU through matched sales were initially permitted only during 1994 and 1995.

The March 1994 amendment did not address "enrichment bypass." Enrichment bypass arises when uranium concentrate produced in one country and enriched in a second country becomes an import of the second country. For example, uranium mined in Russia and enriched in France had been considered as French-origin. In October 1996, DOC and MINATOM reached an agreement to close the enrichment bypass and treat all natural uranium from Russia as Russian origin. In exchange, the portion of the Russian SWU quota that had not been used in previous years could be used in the future. The United States and Russia also agreed to renegotiate the SWU quota in 1998.

${ }^{a}$ At the end of 1991, the political entity known as the Soviet Union was dissolved leaving 15 independent republics.

${ }^{b}$ Certain long-term purchase contracts in force before the Suspension Agreement with Russia were allowed to continue.

Sources: Suspension Agreement with Russia and subsequent amendments-Energy Information Administration, Nuclear Power Generation and Fuel Cycle Report 1995, DOE/EIA-0436(95) (Washington, DC, October 1995), pp.125-127; The Ux Weekly (August 19, 1996), p. 2; Uranium sold by former Soviet Union-J. Steyn, "World Uranium Inventory Changes," paper presented at the World Nuclear Fuel Market 24th Annual Meeting and International Conference on Nuclear Energy, p. 4. 
In September 1996, the agreement was amended to meet a provision in the USEC Privatization Act that sought to eliminate any requirements for USEC to purchase the natural uranium component of Russian LEU delivered after December 31, 1996. Also related to the USEC Privatization Act, USEC in December 1996 transferred to DOE without cost the natural uranium component of Russian LEU purchased in 1995 and 1996. A more detailed description of plans by DOE to sell this Russian feed is presented in Chapter 5.

An offer by TENEX to increase deliveries in 1997 was initially declined by USEC on the basis of economic considerations. USEC stated that increased SWU purchases had contributed to its higher costs of providing enrichment services. ${ }^{62}$ The apparent conflict between operating USEC as a profit-oriented corporation and meeting U.S. nonproliferation objectives received the attention of the U.S. Government. After being threatened with removal as the U.S. Executive Agent, USEC reversed its position and entered into negotiations with TENEX regarding increased deliveries.

In November 1996, USEC and TENEX further amended the original contract by establishing the quantities and prices for the period 1997 through 2001. A new accelerated schedule was implemented, committing USEC to purchase the enrichment contained in LEU blended down from 18 metric tons of HEU in 1997, 24 metric tons of HEU in 1998, and 30 metric tons of HEU per year from 1999 through $2001{ }^{63,64}$ Implementation of the new schedule would result in the blending down to LEU of an additional 22 metric tons of Russian HEU between 1996 and 1998 beyond the quantity specified by the original contract for the same period (Figure 2). The quantity of enrichment to be purchased by USEC had been set for 3.3 million SWU in 1997, 4.4 million SWU in 1998, and 5.5 million SWU in 1999 and subsequent years. As part of the agreement, USEC paid $\$ 100$ million in advance to Russia in December 1996 for future SWU purchases in 1998 and $1999 .{ }^{65}$

To meet the demands of the accelerated schedule, Russia brought a second plant, the Siberian Chemical Enterprise Complex in Krasnoyarsk, on line to increase the capacity to blend down HEU. Previously, blending took place at a facility in Ekaterinburg. Besides increasing the quantity of LEU to be made available through 1998, the November amended agreement is significant in that it eliminates the need for annual negotiations on price and quantity. Thus, considerable uncertainty over the future availability of LEU from Russian HEU was eliminated. Although USEC has a contract with the Russian

\section{Figure 2. Comparison Between the Original and Current Schedules for Blending Down Highly Enriched Uranium (HEU) from Dismantled Russian Nuclear Weapons Pursuant to the Russian HEU Agreement, 1994-2001}

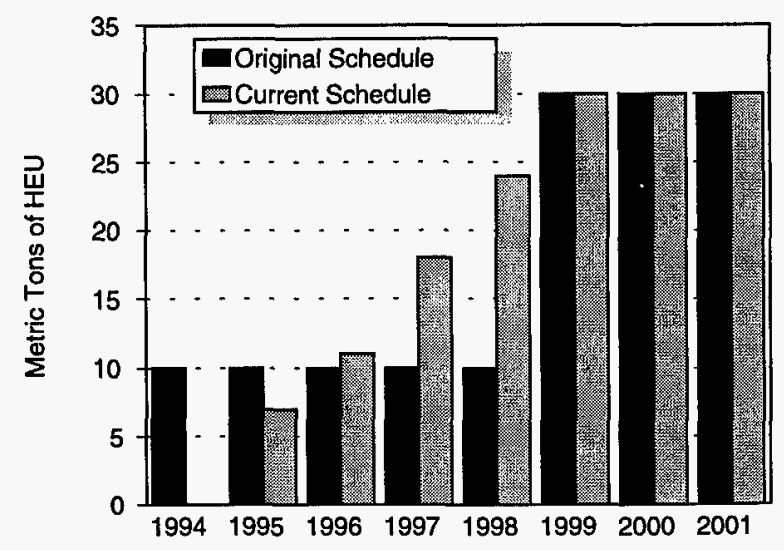

Explanation: Original schedule-Implementation contract for Russian HEU Agreement signed between the United States Enrichment Corporation (USEC) and Techsnabexport (TENEX) in January 1994; Current schedule - actual HEU blended down and delivered to USEC during 1995 and 1996, and the amendment to the Russian HEU Agreement signed between USEC and TENEX in November 1996 for the period 1997-2001.

Source: United States Enrichment Corporation, 1996 Annual Report.

Executive Agent to purchase SWU contained in the LEU, the Russian government in 1997 delayed issuing the licenses required to export the LEU from Russia to USEC. Russian law prohibited the issuance of export licenses until payments were received from the sale of Russian feed to Western suppliers or consumers. While

${ }^{62}$ United States Enrichment Corporation, 1996 Annual Report, p. 11.

${ }^{63}$ USEC's purchase under the November 1996 amendment to the Russian HEU Agreement is for only the enrichment component of Russian LEU derived from the blending down of HEU. Since USEC will not be paying for the natural uranium feed component of the LEU, "SWU" will be used in place of LEU to denote such purchases.

${ }^{64}$ United States Enrichment Corporation, Chronology of the Megatons to Megawatts Contract, as of January 27, 1997 (Bethesda, MD, January 1997), p. 3.

${ }^{65}$ United States Enrichment Corporation, 1996 Annual Report, p. 33. 
negotiations were taking place with Western suppliers for the purchase of the uranium feed, the Russian central bank granted a 2-year extension for receipt of payments. ${ }^{66}$ With this development, deliveries to the United States of LEU derived from Russian HEU were resumed.

\section{Negotiations for Purchasing Russian Feed}

Since at least 1993, MINATOM has been evaluating offers from parties interested in purchasing the Russian feed component that Russia will receive from USEC. ${ }^{67}$ Legislation contained in the USEC Privatization Act authorized USEC to make the feed available to the Russians beginning on January 1, 1997. In August 1997, an agreement in principle was signed between three Western uranium supply companies and MINATOM, for the three companies to purchase Russian feed. ${ }^{68}$ The companies are Cameco Corporation and Cogema, two of the world's largest uranium producers, and Nukem Inc., a uranium trader. The companies agreed to guarantee minimum prices subject to certain conditions and to make advance payments, up to \$US 100 million, annually to MINATOM. Not all the available feed was to be included in the agreement, as Russia could reserve certain, as yet undefined, quantities for blending down to LEU for consumption in Russia, or to fill commercial contracts by its own representatives. Each company's share of the Russian feed to be made available by Russia was as follows: Cameco, 45 percent; Cogema, 45 percent; and Nukem, 10 percent. The purchasing companies would market their shares independently.

In December 1997, MINATOM and Western suppliers suspended negotiations for the purchase of the Russian feed by the Western suppliers.$^{69}$ Cameco Corp., Cogema, and Nukem were unable to receive assurances from MINATOM that an agreement would be (1) enforceable for the proposed 10-year contract and (2) fully sanctioned by the Russian government. MINATOM concluded that the agreement was not in the best economic interests for Russia. It has indicated that it would sell the uranium feed through affiliates at a floor price above the average of world market prices. ${ }^{70}$ In a statement released by Cameco Corp., the Western companies indicated a willingness to resume negotiations as soon as their concerns have been satisfactorily addressed.

\section{Department of Commerce Procedures for Selling Russian Feed}

To meet its legal responsibilities, U.S. Department of Commerce (DOC) has developed a series of procedures to administer and enforce the U.S. quotas for Russian feed as specified by Section 3112 of the USEC Privatization Act (Table 4). DOC's initial proposal was published for public comment in October 1997.71 Based on a review of public comments and discussions with the Ministry of Atomic Energy for the Russian Federation (MINATOM), DOC adopted procedures in January 1998 for selling Russian feed in the United States. $^{72}$ DOC intends to review the procedures in September 1998 to ensure that its statutory obligations are being met.

As an initial step, MINATOM will issue certificates to its marketing agents noting that the Russian feed is to be delivered to the United States for consumption only. The cumulative quantity of Russian feed allocated by the certificates for a given year will not exceed the annual quota established by the USEC Privatization Act. DOC will allow the re-allocation of deliveries among agents or to MINATOM as long as such allocations occur no later than December 1 in any given year. The re-allocation of Russian feed will be confined to deliveries in the same annual period subject to the annual maximum delivery quota. If an agent delivers less than its allocation, the agent may enter into a new contract for the difference between its deliveries and the maximum it was allocated for that year. An agent would forfeit any portion of the annual quota not delivered by December 31 .

All agents authorized by MINATOM to deliver Russian feed to U.S. end users must submit sales contracts for DOC approval. To be approved by DOC, the following

66 "More Feed for Thought," The Ux Weekly (December 15, 1997), p. 1.

${ }^{67}$ Cameco Corporation, "Discussion to Continue Concerning Highly Enriched Uranium," press release (May 8, 1997).

${ }^{68}$ Cameco Corporation, "Cameco Signs Uranium Agreement in Principle with Russia," press release (August 18, 1997).

${ }^{69}$ Ibid.

${ }^{70}$ Ibid.

${ }^{71}$ U.S. Department of Commerce, International Trade Commission, "Agreement Suspending the Antidumping Investigation on Uranium From the Russian Federation," in Federal Register, Vol. 62, October 6, 1997, p. 52322.

${ }^{72}$ C. A. Moss, "DOC Procedures for HEU Natural Uranium Component Sales," memorandum to the Nuclear Energy Institute's Nuclcar Fuel Supply Forum (January 9, 1998). 
requirements must be met: (1) an authorized certificate is provided; (2) the date, amount, and point of each delivery is provided; (3) the contract must state that the material to be sold is of Russian origin; (4) the contract must state that the material is to be sold for consumption only; and (5) the agent must certify that it is still under its annual allocation of the delivery quota, that the Russian feed is Russian uranium intended solely for consumption, and that it does not circumvent the relevant provisions of the USEC Privatization Act. ${ }^{73}$ The DOC will notify the agents of approval or rejection within 10 business days of the contract's submission. All authorized sales agents must submit quarterly reports to DOC providing detailed information on the movement of Russian feed into and out of its accounts.

To ensure the implementation of DOC's procedures, close cooperation will be required between DOC and MINATOM. MINATOM is required to provide DOC with a copy of the certificates issued to its marketing agents. Also, DOC and MINATOM will review jointly the data pertaining to deliveries made in the prior year. 


\section{Commercialization of U.S. Government Surplus Inventories}

\section{Development of Disposition Policies and Programs}

The United States is reducing its inventory of nuclear materials to be consistent with the realities of arms reduction. The policies and implementation of the U.S. Government programs that affect the disposition of surplus inventories of HEU and plutonium and commercial-grade natural uranium and LEU are described in this chapter. Each program involves the conversion of all or part of the respective surplus inventories to fuel for use in commercial nuclear power plants.

The Nuclear Weapons Council, made up of representatives from the DOE, Department of Defense, and the Joint Chiefs of Staff, recommends to the President the quantities of uranium and plutonium required for national security purposes. The quantities of material in excess of those requirements are deemed to be surplus. The time frame over which the surplus material could be made available for commercial use is dependent on the successful resolution of multiple issues, which sometimes are competing. These issues have included technical feasibility, rate of weapons dismantlements, nonproliferation, economics, international relations, the Nation's budget, health and safety, and the environment. In addition, input from the public has been sought and considered in reaching major policy decisions. As a result, a period of about 5 years elapsed after the end of the Cold War before U.S. Government surplus inventories began to be made available to the commercial nuclear fuel market (Appendix B, Table B1).
There was no public policy or law for dealing with U.S. Government inventories when the Cold War ended. The legal foundation for identifying U.S. surplus uranium that could be converted to commercial use was established by the Energy Policy Act of 1992 (EPACT). EPACT directs the Secretary of Energy to develop "a comprehensive inventory of all Government owned uranium or uranium equivalents, including natural uranium, depleted tailings, low-enriched uranium, and highly enriched uranium available for conversion to commercial use." ${ }^{.74}$ Furthermore, EPACT required the Secretary of Energy to develop a plan to convert HEU to LEU and to provide recommendations for implementing the plan. Later, the USEC Privatization Act provided $D O E$ with the authority to transfer uranium, including HEU-derived LEU, to USEC and to sell surplus commercial-grade inventories in the marketplace upon satisfying certain conditions. ${ }^{75}$

Neither EPACT nor subsequent legislation contained provisions that required the conversion of plutonium into commercial fuel. The U.S. Government's concern for the potential proliferation of nuclear weapons has led to the development of plans to dispose of weaponsusable plutonium as well as HEU. ${ }^{76}$ Considerable effort has been spent in the study of acceptable options for the disposition of U.S. plutonium. President Bush's National Security Advisor commissioned the U.S. National Academy of Sciences in 1992 to study and report on the options available for disposing of surplus plutonium. ${ }^{77}$ The findings of the National Academy of Sciences served as the foundation for decisions to pursue the plutonium disposition strategy described in this chapter.

1992).

74 Energy Policy Act of 1992, Section 1016(Uranium Inventory Study) of Title X-Remedial Action and Uranium Revitalization (October

75 Public Law 104-134, Balanced Budget Down Payment Act, Subchapter A-USEC Privatization Act, Section 3112 (c-Transfers to the Corporation, d-Inventory Sales) (April 1996).

76 "Weapons-usable" fissile materials can be used to produce both less sophisticated nuclear weapons and more advanced weapons which require "weapons-grade" fissile materials to produce more predictable explosions.

77 National Academy of Sciences, Committee on International Security and Arms Control, Management and Disposition of Excess Weapons Plutonium, National Academy Press (Washington, DC, January 24, 1994), p. v. 
The nuclear nonproliferation objectives of the U.S. Government were set forth in the Nonproliferation and Export Control Policy announced by President Clinton in September 1993. This policy commits the United States to seek elimination, where possible, of inventories of weapons-usable fissile materials. Accordingly, in March 1995, President Clinton declared as surplus 200 metric tons of HEU and plutonium held for national security purposes. As part of the Openness Initiative announced in February 1996, the Secretary of Energy reported a revised surplus inventory of about 213 metric tons, consisting of 174.3 metric tons HEU and 38.2 metric tons plutonium. ${ }^{78}$ To demonstrate the irreversibility of its decision to declare fissile materials as surplus to defense needs, the United States has committed to make available 90 metric tons of HEU and plutonium for international inspection by the IAEA. ${ }^{79}$

In addition to HEU and plutonium, the U.S. Government holds surplus inventories of commercial-grade natural uranium and LEU that cannot be used in weapons without further enrichment. Thus, the Government's plans for disposing of commercial-grade natural uranium and LEU are driven more by economic considerations than by nonproliferation objectives.

DOE, which is the steward of U.S. Government inventories of fissile materials, has moved to implement the President's nonproliferation policy and the directives of the legislation described above. In January 1994, the Secretary of Energy created the Fissile Materials Disposition Project. ${ }^{80}$ The Office of Fissile Materials Disposition was created later in the year to develop the Department's recommendations and to direct the implementation of decisions concerning disposition of surplus weapons-grade fissile materials. The Office of Nuclear Energy, Science and Technology has been given responsibility for managing the sale of surplus commercialgrade uranium.

In developing implementation plans for disposing of nuclear materials, DOE was required to follow the guidelines and procedures contained in the National Environmental Policy Act of 1969 (NEPA process). ${ }^{81}$ The NEPA process ensures that potential impacts on the environment will be considered for each proposed action. Pursuant to its statutory obligations regarding the NEPA process, the Environmental Protection Agency reviews each proposed action. Assessments of the potential environmental impacts that could arise from each proposed DOE disposition plan have been made available for public comment. In the NEPA documents, DOE also has included assessments of costs, socioeconomic impacts, and proliferation concerns.

The effort required to complete the NEPA process for a particular proposed plan reflects the plan's complexity (Appendix C, Table C1). Plans for the storage and disposition of weapons-usable HEU and plutonium required the analysis of complex technical procedures including the processing, handling, and transporting of materials. In addition, DOE has sought public participation in developing preferred alternatives. For the disposition of HEU, 15 months passed between the time that DOE announced its intent to prepare a separate EIS and the release of a final EIS (Appendix C, Table C1).

In contrast to weapons-usable materials, the proposed action to sell surplus commercial-grade uranium and LEU was not anticipated to require extraordinary handling, processing, or waste management activities. The ongoing commercial operations of the enrichment plants are covered by existing NEPA documents. Through the issuance of a Finding of No Significant Impact, DOE determined that the sale of surplus commercial-grade uranium "does not constitute a major Federal action significantly affecting the quality of the human environment within the meaning of the National Environmental Policy Act of $1969 . "{ }^{2}$ Therefore, preparation of an EIS was not required for this proposed action. As a result, only 3 months passed between DOE's initial notification of the proposed action and the completion of the final document required by the Act (Appendix C, Table C1).

78 U.S. Department of Energy, Record of Decision for the Storage and Disposition of Weapons-Usable Fissile Materials Final Programmatic Environmental Impact Statement (Washington, DC, January 14, 1997), Footnote 1, p. 2.

79 U.S. Department of Energy, "Pena Doubles Amount of U.S. Plutonium and Highly Enriched Uranium Available for International Inspection," press release (Washington, DC, September 29, 1997).

80 U.S. Department of Energy, Office of Fissile Materials Disposition, Long-Term Storage and Disposition of Weapons-Usable Fissile Materials Programmatic Environment Statement Implementation Plan, DOE/IS-0229-IP (Washington, DC, March 1995), p. 1-3.

81 The NEPA process in accordance with the U.S. Department of Energy's NEPA implementing procedures and guidelines (10 CFR Part 1021) and the Council on Environmental Quality regulations implementing NEPA (40 CFR Parts 1500-1508).

82 U.S. Department of Energy, Sales of Surplus Natural and Low Enriched Uranium Finding of No Significant Impact (Washington, DC, October 1996) P. 6. 


\section{Highly Enriched Uranium}

\section{Surplus Inventory Characterization}

DOE has provided detailed accounting of the 174 metric tons of U.S. HEU declared as surplus to national defense needs (Table 5). More than half of the material is stored at the $\mathrm{Y}-12$ Plant in Oak Ridge, Tennessee. ${ }^{83}$ The HEU is in a variety of physical forms, including metal, oxide, aluminum-uranium alloy, solutions, and processed spent fuel. HEU can also be characterized by ${ }^{235} \mathrm{U}$ assay and isotopic or chemical impurities. In contrast to HEU under the Russian HEU Agreement, much of the U.S. surplus contains less than 90 percent ${ }^{235} \mathrm{U}$. However, all uranium enriched to 20 percent or greater ${ }^{235} \mathrm{U}$ is considered "weapons-usable." Isotopic composition is an important factor in determining potential commercialization. Certain isotopes in higher than usual quantities pose as a radiation hazard during handling ${ }^{(232} \mathrm{U}$ and $\left.{ }^{234} \mathrm{U}\right)$ and inhibit reactor performance $\left({ }^{236} \mathrm{U}\right) .{ }^{84}$

\section{DOE HEU Disposition Program}

In April 1995, DOE announced that it intended to prepare an environmental impact statement on the disposition of surplus HEU (HEU EIS) that would be separate from the overall weapons-usable disposition plan announced a year earlier (Appendix C, Table C1). ${ }^{85}$ A nominal 200 metric tons was considered to include HEU that has been declared surplus or may be declared surplus should future arms reduction treaties be enacted. The HEU Final EIS provided a Preferred Alternative from an assessment of a "no action alternative" and four reasonable alternatives. Three of the four reasonable alternatives considered commercialization for between 25 and 85 percent of the inventory, with the remainder being disposed of directly as waste. Direct disposal of all the surplus HEU was considered as the fourth reasonable alternative. The no action alternative considered continuing the storage of HEU.

In July 1996, DOE announced its Record of Decision (ROD) concerning the decision to implement the
Preferred Alternative advanced in the HEU Final EIS. ${ }^{86}$ The Preferred Alternative specifies that all the U.S. surplus HEU would be made non-weapons-usable by blending it down to LEU over a 20-year period (Figure 3). The resultant LEU is considered proliferation resistant because it cannot be used for manufacturing nuclear weapons without expensive and time-consuming enrichment in a plant that can be relatively easy to identify. According to the ROD, DOE plans to make available up to 85 percent of ensuing LEU for use in commercial fuel. This commercial-grade LEU will have a ${ }^{235} \mathrm{U}$ content of between 4 and 5 percent. LEU that can not be economically made to conform to commercial specification or accepted deviation will be disposed of as low-level waste after further blending down to 0.9 percent ${ }^{235} \mathrm{U}$. Some of the HEU-bearing spent fuel might be stored for possible disposal in a high-level waste depository pursuant to the National Waste Policy Act.

An assessment of the following three technologies for the blending down of HEU was contained in the HEU Final EIS: (1) uranyl nitrate hexahydrate (UNH), (2) molten metal, and (3) $\mathrm{UF}_{6}$. The $\mathrm{UF}_{6}$ technology is applicable only to HEU that is already in the form of $\mathrm{UF}_{6}$. No plants in the United States are currently capable of converting HEU metal or oxide into $\mathrm{UF}_{6}$, the typical form of LEU delivered to fuel fabricators. Four plants, two U.S. Government and two commercial, have the capability of blending down HEU metal or oxide with UNH technology: (1) DOE's Y-12 Plant in Oak Ridge, Tennessee; (2) DOE's Savannah River site in Aiken, South Carolina; (3) Babcock \& Wilcox Naval Nuclear Fuels Division in Lynchburg, Virginia; and (4) Nuclear Fuel Services, Inc., in Erwin, Tennessee. Only the Y-12 Plant can employ the molten metal technology. Because the output cannot be used by the fuel fabrication industry, the molten metal technology would be used only for blending HEU to waste.

UNH produced from blending down HEU metal or oxide would be delivered to fuel fabricators, where it would then be converted to uranium dioxide $\left(\mathrm{UO}_{2}\right)$ powder, which can be pelletized for use in fuel rods. To foster the acceptance of UNH in place of $\mathrm{UF}_{6}$, the American Society for Testing and Materials has created

${ }^{83}$ U.S. Department of Energy, Office of Fissile Materials Disposition, Highly Enriched Uranium Disposition Plan (Washington, DC, September 1996).

${ }_{84}$ C. Williams III and J. Arbital, "Disposition of Excess Highly Enriched Uranium Status and Update," paper presented at the Nuclear Energy Institute's International Uranium Seminar 97 (Monterey, CA, September 28-October 1, 1997), p. 12.

${ }_{85}$ U.S. Department of Energy, "Notice of Intent to Prepare a Separate Environmental Impact Statement for the Disposition of Highly Enriched Uranium," in Federal Register, April 5, 1995.

${ }^{86}$ U.S. Department of Energy, "Record of Decision for the Disposition of Surplus Highly Enriched Uranium Final Environmental Impact Statement," in Federal Register, Vol. 61 (August 5, 1996), p. 40619-40629. 
Table 5. Characterization of Inventory in Relation to the U.S. Department of Energy's Disposition Program for Surplus Weapons-Usable Highly Enriched Uranium (HEU), as of February 28, 1998

\begin{tabular}{|c|c|c|c|c|c|c|}
\hline $\begin{array}{l}\text { Quantity } \\
\text { (metric } \\
\text { tons) }\end{array}$ & Form & $\begin{array}{l}\text { Average } \\
{ }^{235} \mathrm{U} \\
\text { Assay } \\
\text { (percent) }\end{array}$ & $\begin{array}{c}\text { Commercial } \\
\text { Character of } \\
\text { Derived } \\
\text { LEU" }\end{array}$ & $\begin{array}{c}\text { Proposed } \\
\text { Start Year for } \\
\text { Commercial } \\
\text { Use }\end{array}$ & $\begin{array}{c}\text { Commercial } \\
\text { Outlet }^{\mathrm{b}}\end{array}$ & Comments \\
\hline 13 & $\mathrm{UF}_{6}$ & 75.7 & Spec & Ongoing & $\begin{array}{l}\text { Transferred to } \\
\text { USEC in } 1993 \text { for } \\
\text { subsequent sale. }\end{array}$ & $\begin{array}{l}\text { To cover costs } \\
\text { associated with } \\
\text { liabilities at DOE-owned } \\
\text { enrichment plants. } \\
\text { Subject to IAEA } \\
\text { inspection as HEU is } \\
\text { blended down into LEU. }\end{array}$ \\
\hline 50 & $\begin{array}{l}\text { Metal, } \\
\text { Oxide }\end{array}$ & 41.3 & Spec & 1998 & $\begin{array}{l}\text { Transferred to } \\
\text { USEC beginning in } \\
1998 \text { for } \\
\text { subsequent sale. }\end{array}$ & $\begin{array}{l}\text { Directed by USEC } \\
\text { Privatization ACt (1996) } \\
\text { Committed to IAEA } \\
\text { safeguards; material } \\
\text { will be available for } \\
\text { inspection upon } \\
\text { undergoing disposition. }\end{array}$ \\
\hline 38 & $\begin{array}{l}\text { Metal, } \\
\text { Fuel } \\
\text { elements, } \\
\text { Oxide }\end{array}$ & 66.0 & Off-spec & By 2003 & $\begin{array}{l}\text { Transfer to TVA for } \\
\text { direct reactor use: } \\
\text { lead test assembly } \\
1999 \text {, reactor } \\
\text { reloads beginning } \\
\text { by } 2003 \text {. }\end{array}$ & $\begin{array}{l}\text { Utilization plan for at } \\
\text { least } 30 \text { metric tons } \\
\text { HEU pursuant to } \\
\text { Memorandum of } \\
\text { Understanding between } \\
\text { DOE and TVA, January } \\
1997 \text {. Other HEU could } \\
\text { be utilized, the } \\
\text { remainder disposed of } \\
\text { as waste. }\end{array}$ \\
\hline 10 & Metal & 93.2 & Spec & Possibly 2003 & Not determined. & $\begin{array}{l}\text { Placed under IAEA } \\
\text { safeguards in } 1995 .\end{array}$ \\
\hline 45 & Assorted & Various & Largely Spec & $\begin{array}{l}\text { Possibly some } \\
\text { before } 2005\end{array}$ & Not determined. & $\begin{array}{l}\text { Most commercialization } \\
\text { after 2010; some to be } \\
\text { disposed of as waste. }\end{array}$ \\
\hline 16 & $\begin{array}{l}\text { Spent } \\
\text { fuel }\end{array}$ & Various & N/A & N/A & N/A & Waste. \\
\hline 2 & Assorted & Various & N/A & N/A & N/A & Waste. \\
\hline 174 & & & & & & \\
\hline
\end{tabular}

${ }^{\mathrm{a}}$ The isotopic or chemical composition of the HEU and the selection of blendstock will determine whether or not the downblended low-enriched uranium (LEU) is within the specifications developed by the American Society for Testing and Materials (ASTM): specification (spec) versus off-specification (off-spec).

${ }^{b}$ Highly enriched $\mathrm{UF}_{6}$ is being blended down directly into low-enriched $\mathrm{UF}_{6}$, a marketable nuclear fuel product, in a commercial uranium enrichment production stream. All other forms of HEU will require blending down into an intermediate form of lowenriched uranium before it can be used in producing commercial reactor fuel.

$\mathrm{UF}_{6}=$ uranium hexafluoride.

IAEA = International Atomic Energy Agency, TVA=Tennessee Valley Authority, USEC=United States Enrichment Corporation. $\mathrm{N} / \mathrm{A}=$ not applicable.

Sources: U.S. Department of Energy, Office of Fissile Materials Disposition, Highly Enriched Uranium Disposition Plan (Washington, DC, September 1996); C. Williams III and J. Arbital, "Disposition of Excess Highly Enriched Uranium Status and Update," paper presented at the Nuclear Energy Institute's Intemational Uranium Seminar 97 (Monterey, CA, September 28October 1, 1997), p. 12; D. Tousley, personal correspondence (DOE Office of Fissile Materials Disposition, Washington, DC, November 18, 1997); R. Schmidt, personal communication (HEU Disposition Program Office, Oak Ridge, TN, March 3, 1998). 
Figure 3. Relationship of the U.S. Department of Energy's (DOE) Surplus Highly Enriched Uranium (HEU) Disposition Program and the Civilian Nuclear Fuel Cycle

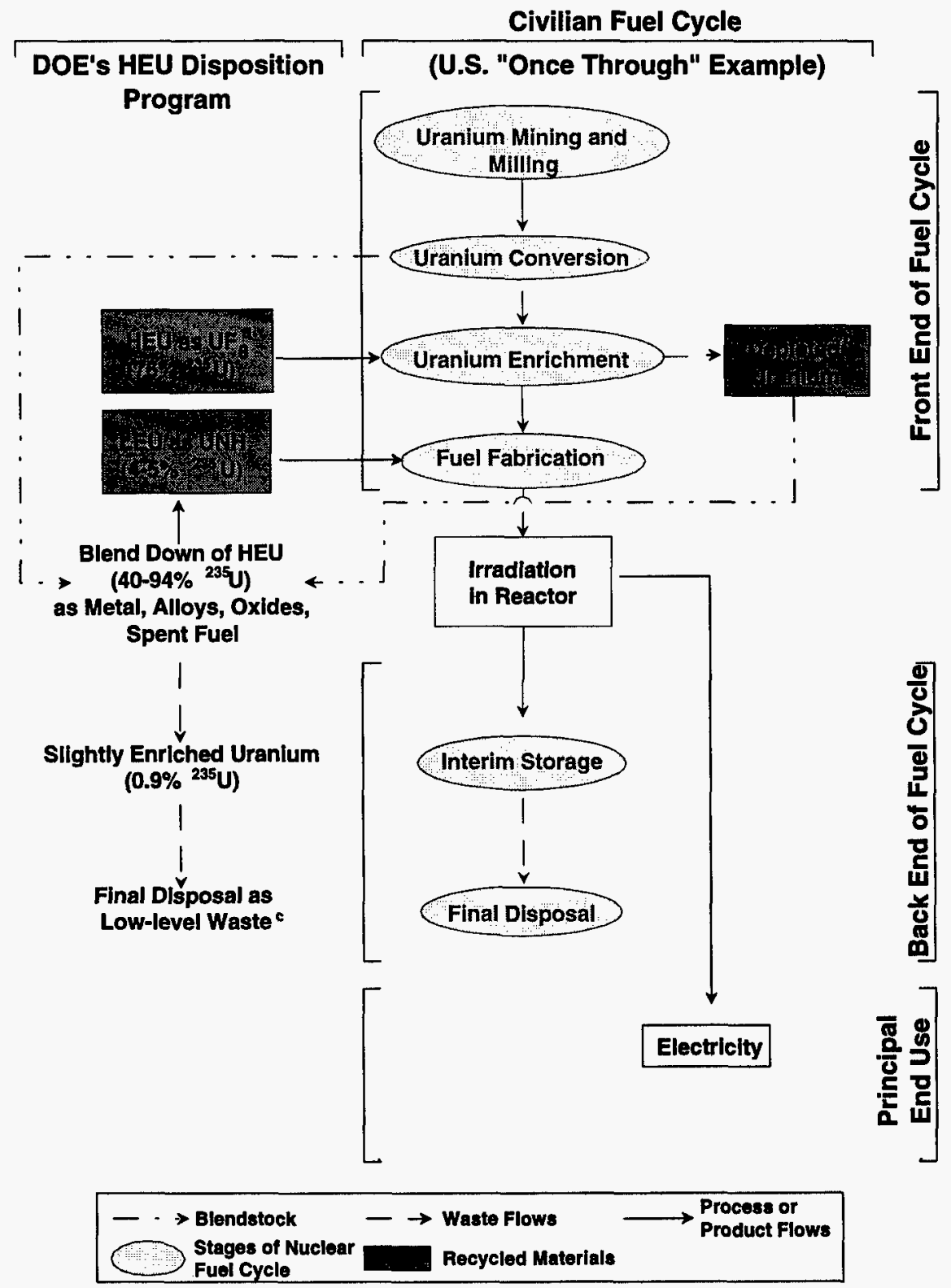

${ }^{a} \mathrm{HEU}$ as uranium hexafluoride $\left(\mathrm{UF}_{6}\right)$ is converted into low-enriched uranium (LEU) for commercial use by blending $\mathrm{HEU}$ with LEU as $U_{6}$ in the enrichment production stream.

${ }^{b}$ The portion of the uranium product stream that becomes depleted in ${ }^{235} \mathrm{U}$ during enrichment. Depleted uranium, generated by the U.S. Government's former enrichment program, will be used to blend down some of the HEU.

${ }^{c}$ Spent fuel could be stored at an interim site pending the completion of a geologic repository for final disposal as high-level waste.

$U F_{6}=$ Uranium hexafluoride.

$\mathrm{UNH}=$ Uranyl nitrate hexahydrate.

Source: Energy Information Administration, Office of Coal, Nuclear, Electric and Altemate Fuels. 
new standards that can be used by the fuel fabrication industry to measure quality.

A cost comparison of blending HEU into LEU for commercial nuclear fuel and direct disposal was included in the HEU Final EIS. The estimated cost per kilogram HEU was determined for each technology as follows: (1) $\$ 13,900$ for metal blending to slightly enriched uranium (0.9 percent ${ }^{235} \mathrm{U}$ ) for disposal; (2) $\$ 22,900$ for UNH blending to slightly enriched uranium for disposal; (3) $\$ 3,200$ for $\mathrm{UF}_{6}$ blending to LEU (4 percent ${ }^{235} \mathrm{U}$ ) for commercial use; and (4) $\$ 5,700$ for UNH blending to LEU for commercial use. For options 3 and 4 , the potential sales revenue was estimated at $\$ 11,700$ per kilogram HEU, based on commercial market prices at the time of the assessment. The total cost of using option 2 for the disposition of the entire nominal 200 metric tons as waste was estimated at $\$ 3.4$ billion. ${ }^{87}$ In contrast, the Preferred Alternative (commercialization, 170 metric tons; direct disposal as waste, 30 metric tons) would result in a net return of $\$ 340$ million to $\$ 770$ million.

\section{HEU Available for Commercialization}

In September 1996, the Office of Fissile Materials Disposition provided a disposition plan based on the potential for surplus HEU inventories to be blended down to LEU that would meet commercial specification. Inventories requiring more extensive purification presumably would be made available at later dates. The schedule proposed in the plan was as follows: (1) 60 metric tons available today to 5 years; (2) 40 metric tons available over 5 to 15 years; (3) 36 metric tons difficult to recover over 15-20 years; and (4) 26 metric tons likely to be waste. In addition to these inventories, 13 metric tons have been transferred to USEC and will be blended down for commercial use by the end of 1998 .

The characterization of DOE's HEU inventory is work in progress. Since the end of the fiscal year ending September 30,1997, DOE has further delineated the characteristics of the inventory (Table 5). ${ }^{88}$ Under current plans, as much as 101 metric tons of surplus U.S. HEU could be transferred to Government-owned corporations: USEC and the Tennessee Valley Authority. DOE has not announced specific plans for the sale or transfer of the remaining surplus HEU. At least 18 metric tons will be processed for disposal as waste. ${ }^{89}$

\section{Transfers to the United States Enrichment Corporation}

To meet certain legal obligations, DOE began transferring surplus HEU in 1993 without charge to USEC. Two types of HEU inventories are included in the transfers: (1) 13 metric tons as $\mathrm{UF}_{6}$ and (2) 50 metric tons as metal and oxide. The 13 metric tons were transferred to fund liabilities at DOE-owned enrichment plants pursuant to EPACT. As $\mathrm{UF}_{6}$, it can be blended down directly to LEU in the production enrichment stream. USEC anticipates that the blending down of the highly enriched $\mathrm{UF}_{6}$ will be completed by the end of $1998 .{ }^{90}$

The Secretary of Energy was directed by the USEC Privatization Act to transfer up to 50 metric tons of HEU without charge to USEC. ${ }^{11}$ This transfer has enhanced the value of USEC as the corporation prepared for privatization (see page 18). To implement the transfer, DOE was required to (1) finalize a transfer agreement with USEC, (2) complete inventory selection and characterization, (3) assist USEC in procuring services for down-blending, and (4) develop procedures for refunding reimbursable expenses incurred by USEC. ${ }^{92}$ In April 1998, a Memorandum of Agreement was signed between DOE and USEC initiating the transfer of 50 metric tons of HEU along with 7,000 metric tons of natural $\mathrm{UF}_{6} \cdot{ }^{93} \mathrm{DOE}$ expects the transfer to be completed around 2003.

The LEU that would be made available for commercial use from the blending down 63 metric tons of HEU contains 5.7 million SWU (Table 6). This LEU contains an equivalent natural uranium feed component contributed from both the HEU and the blendstock. To commercialize 63 metric tons of HEU transferred by DOE, USEC is anticipated to use the following sources of uranium for blendstock: (1) internal stockpiles held since USEC was created from DOE, (2) transfer by DOE of 7,000 metric tons of natural $\mathrm{UF}_{6}$, or (3) purchases from

${ }^{87}$ Ibid, p. 40623.

${ }^{88}$ R. Schmidt, personal communication (HEU Disposition Program Office, Oak Ridge, TN, March 3, 1998).

${ }^{89}$ Ibid.

${ }^{90}$ United States Enrichment Corporation, Annual Report 1996, p. 31.

91 USEC Privatization Act (April 26, 1996), Section 3112(c).

92 C.K. Williams III, and J. Arbital, "Disposition of Excess Highly Enriched Uranium Status and Update," paper presented at the Nuclear Energy Institute's International Uranium Seminar 97 (Monterey, CA, September 28-October 1, 1997), p. 3.

${ }^{93}$ The Ux Weekly (April 27, 1998), p. 3. 
Table 6. Equivalent Natural Uranium Feed and SWU Components of Low-Enriched Uranium (LEU) Derived from U.S. Highly Enriched Uranium (HEU) Based on the U.S. Department of Energy's Plans to Transfer Surplus HEU to the United States Enrichment Corporation (USEC) and the Tennessee Valley Authority (TVA)

\begin{tabular}{|c|c|c|c|c|c|c|}
\hline \multirow{2}{*}{$\begin{array}{c}\text { HEU } \\
\text { Quantity } \\
\text { (metric tons) }\end{array}$} & \multirow{2}{*}{$\begin{array}{c}\text { Average }{ }^{235} \mathbf{U} \\
\text { Assay } \\
\text { (percent) }\end{array}$} & \multicolumn{2}{|c|}{$\begin{array}{l}\text { Uranium Feed Component } \\
\text { (million pounds } \mathrm{U}_{3} \mathrm{O}_{8} \text { ) }\end{array}$} & \multicolumn{2}{|c|}{$\begin{array}{l}\text { Enrichment Component } \\
\text { (million SWU) }\end{array}$} & \multirow[b]{2}{*}{$\begin{array}{l}\text { Recipient and } \\
\text { Time of Transfer }\end{array}$} \\
\hline & & $\mathrm{HEU}^{\mathrm{b}}$ & $\begin{array}{l}\text { Blended LEU } \\
\text { Product }^{c}\end{array}$ & $\mathrm{HEU}^{\mathrm{b}}$ & $\begin{array}{l}\text { Blended LEU } \\
\text { Product }^{\mathrm{c}} \\
\end{array}$ & \\
\hline 13 & 75.7 & 6.2 & 9.6 & 2.1 & 2.3 & USEC: $1993^{d}$ \\
\hline 50 & 41.3 & 13.0 & 14.1 & 4.2 & 3.4 & USEC: $1998-2003$ \\
\hline $38^{\ominus}$ & 66.0 & 15.5 & 17.7 & 5.2 & 4.3 & TVA: $2003-2015^{f}$ \\
\hline
\end{tabular}

${ }^{a}$ The separative work units (SWU) of enrichment required to produce equivalent LEU, assuming enrichment tails at 0.30 percent ${ }^{235} \mathrm{U}$.

${ }^{\text {b }}$ The equivalent $\mathrm{U}_{3} \mathrm{O}_{8}$ or SWU contained in HEU with the following average ${ }^{235} \mathrm{U}$ assays: 13 metric tons, 75.7 percent; 50 metric tons, 41.3 percent; 38 metric tons, 66.0 percent.

'The equivalent $\mathrm{U}_{3} \mathrm{O}_{8}$ or SWU contained in LEU bended down from HEU. Different blendstock assays are assumed for each $\mathrm{HEU}$ class as follows: 13 metric tons HEU-LEU (2.0 percent $\left.{ }^{235} \mathrm{U}\right), 50$ metric tons HEU-natural uranium (0.71 percent $\left.{ }^{235} \mathrm{U}\right), 38$ metric tons HEU-slightly enriched uranium (1.25 percent $\left.{ }^{235} \mathrm{U}\right)$ and natural uranium (0.71 percent $\left.{ }^{235} \mathrm{U}\right)$.

${ }^{d}$ USEC expects to complete the blending of highly enriched uranium hexafluoride $\left(U F_{6}\right.$ ) to low-enriched $U F_{6}$ by 1998.

'The actual amount may be less depending on the final characterization of the HEU.

fTVA expects to use a small amount of LEU derived from HEU as a lead fuel assembly demonstration scheduled for 1999.

Source: R. Schmidt, personal communication (HEU Disposition Program Office, Oak Ridge, TN, March 3, 1998).

the commercial market. Of these sources, only one inventory class, the 7,000 metric tons of natural $\mathrm{UF}_{6}$, is U.S. surplus defense material-it is already accounted for as part of "commercial-grade" inventories described later in this chapter. To avoid double counting the portion of the 7,000 metric tons of natural $\mathrm{UF}_{6}$ that could be used as blendstock, only the natural uranium component of the HEU was considered in this report. Thus, the commercialization of 63 metric tons of HEU undergoing transfer to USEC would displace the equivalent of 19.2 million pounds $\mathrm{U}_{3} \mathrm{O}_{8}$ from traditional sources of uranium (Table 6).

No legal restrictions have been placed on USEC for selling the natural uranium or SWU components of LEU derived from blending down 13 metric tons of highly enriched $\mathrm{UF}_{6}$. For the 50 metric tons of HEU, the USEC Privatization Act authorized the quantity and timing by which USEC can make deliveries to commercial end users. To apply the restrictions, the Act considered the quantities of equivalent natural uranium and SWU contained in the transfers of 50 metric tons of HEU and 7,000 metric tons of natural uranium (see page 37) as an aggregate amount. The restrictions are as follows: (1) deliveries of uranium to commercial end users are not permitted before January 1, 1998; (2) deliveries in any calendar year after 1997 are not permitted to exceed 10 percent of the transferred uranium (by $\mathrm{UF}_{6}$ content) or the equivalent of 4 million pounds $\mathrm{U}_{3} \mathrm{O}_{8}$; and (3) no more than 800,000 SWU contained in LEU derived from the HEU can be delivered in any calendar year.

\section{Use of Off-Specification HEU by the Tennessee Valley Authority}

DOE had been investigating the option of commercializing surplus HEU classified as "off-specification." LEU derived from blending down off-specification HEU would not meet the specifications established by the American Society for Testing and Materials for commercial nuclear fuel. The presence of the isotope ${ }^{236} \mathrm{U}$ in LEU derived from off-specification HEU could have an adverse effect on reactor performance. ${ }^{94}$ Nevertheless, DOE anticipates that such LEU can be used to fuel commercial nuclear reactors.

In January 1997, DOE and the Tennessee Valley Authority (TVA) reached a Memorandum of Understanding (MOU) whereby LEU blended down from DOE

94 Ibid., p. 12. 
surplus off-specification HEU would be used by TVA to fabricate nuclear fuel to produce electricity. ${ }^{95}$ By implementing the MOU, TVA would acquire nuclear fuel at costs significantly below market prices. DOE and TVA intend to "share equally in any cost savings derived from TVA's use of off-specification LEU" derived from DOE HEU.96 Meanwhile, DOE would be able to avoid additional costs of preparing offspecification HEU for direct disposal.

To meet the obligations of the MOU, DOE would blend down 38 metric tons of off-specification HEU to LEU, using a combination of natural uranium and slightly enriched uranium ${ }^{235} \mathrm{U}$ content of 1.25 percent) from its own inventories as blendstock. ${ }^{97}$ By using blendstock that meets ASTM specifications, the ${ }^{236} \mathrm{U}$ content of the resultant LEU is anticipated to be reduced to a level that would not adversely affect reactor performance. The blending could take place at DOE's Savannah River site in South Carolina. With the exception of new facilities that could be required, DOE would be liable for all environmental remediation or decontamination and decommissioning of any existing DOE sites involved in the implementation of the MOU. If blending cannot be done at the Savannah River site, DOE would be responsible for providing TVA with LEU from another site.

By utilizing LEU derived from the 38 metric tons of HEU made available by DOE, TVA would avoid purchasing 4.3 million SWU from the commercial market (Table 6). This LEU contains an equivalent natural uranium feed component contributed from both the HEU and the blendstock. For blendstock, DOE is assumed to supply uranium held in forms that would not be readily saleable on the commercial market. Because this anticipated blendstock supply is not part of any other U.S. surplus inventory quantified in this report, the utilization of 38 metric tons of HEU by TVA would displace the quantity of natural uranium contained in both the HEU and blendstock, equivalent to 17.7 million pounds of $\mathrm{U}_{3} \mathrm{O}_{8}$ (Table 6).

In return for receiving HEU and blendstock at no charge, TVA will be responsible for: (1) sampling, analysis, packaging, transportation, and storage of the blending material within 2 years after an execution of an interagency agreement; (2) taking possession and title to the LEU at the blending site; (3) paying any additional capital costs for special equipment that may be required at the blending site in the year that they are incurred; (4) paying for support services provided by DOE; (5) paying for the incremental operating cost of blending HEU at the Savannah River site that is in excess of DOE's statutory limits; (6) paying all costs to use the LEU once possession is taken, including transportation of LEU to fuel fabricator, fuel fabrication, and licensing and operation of fuel assembles made from the blended LEU. TVA also would be responsible for the storage and disposal of all related spent fuel pursuant to the National Waste Policy Act.

To demonstrate the feasibility of the program, TVA proposed to load lead assemblies containing LEU blended down from off-specification $\mathrm{HEU}$ into an operating reactor..$^{98}$ TVA anticipates that the demonstration could begin by early 1999 . For the proposed demonstration, DOE will provide TVA with HEU and blendstock at no charge. Both parties will share the costs of blending down the HEU and fuel fabrication. Any cost savings that may be realized by TVA as a result of the demonstration will be shared equally with DOE. Upon successful demonstration, fuel reloading could begin by 2003. DOE anticipates that the transfer of 30 metric tons would continue to $2011 .{ }^{99}$ The use of additional HEU could extend the program through 2015.

\section{HEU Made Available for International Inspection}

The U.S. Government has designated approximately 73 metric tons of HEU as available for IAEA-sponsored international inspection. ${ }^{100}$ In 1995, 10 metric tons of metal stored at the Y-12 Plant in Oak Ridge were placed under IAEA safeguards, becoming the first HEU to be made available for international inspection. In 1996, the Secretary of Energy made available for international inspection the following quantities of HEU: 13 metric

95 U.S. Department of Energy and the Tennessee Valley Authority, "Memorandum of Understanding Between the Department of Energy and the Tennessee Valley Authority for a Program to Utilize Off-Specification Low Enriched Uranium Derived from Highly Enriched Uranium as Commercial Nuclear Power Reactor Fuel" (January 1997).

96 Ibid; p. 1.

97 R. Schmidt, personal communication (HEU Disposition Program Office, Oak Ridge, TN, March 3, 1998).

98 C.K. Williams III and J. Arbital, "Disposition of Excess Highly Enriched Uranium Status and Update," paper presented at the Nuclear Energy Institute's International Uranium Seminar 97 (Monterey, CA, September 28-October 1, 1997), p. 3.

99 Ibid; p. 17.

${ }^{100}$ D. Tousley, personal correspondence, U.S. Department of Energy, Office of Fissile Materials Disposition (Washington, DC, November 18, 1997). 
tons of highly enriched $\mathrm{UF}_{6}$ that had been transferred from DOE to USEC in 1994 and 13 metric tons of oxide and metal that is part of the pending transfer of 50 metric tons of HEU from DOE to USEC. A subsequent announcement by the Secretary of Energy in September 1997 committed the remaining 37 metric tons of the pending HEU transfer. In the case of transfers to USEC, the HEU will be made available for inspection as the material is undergoing disposition. ${ }^{101}$ Since much of the HEU involved in the 1997 announcement is in the form of metal that had been fabricated for weapons, the shape of the material must first be altered so as not to disclose information classified for national defense purposes. ${ }^{102}$ In December 1997, IAEA began activities to verify that highly enriched $U_{6}{ }_{6}$ was being blended down into LEU at the Portsmouth plant. ${ }^{103}$ This was the first time that IAEA verified the transformation of nuclear material no longer needed for defense purposes for use as commercial nuclear fuel.

\section{Commercial-Grade Uranium}

\section{DOE Sales of U.S. Natural $\mathrm{UF}_{6}$ and LEU}

In July 1996, DOE published in the Federal Register a Notice of Intent to sell approximately 21.5 million pounds $\mathrm{U}_{3} \mathrm{O}_{8}$ equivalent of commercial-grade uranium declared as surplus to U.S. national defense purposes. ${ }^{104}$ This surplus consists of natural uranium in the form of $\mathrm{UF}_{6}$ (20.3 million pounds $\mathrm{U}_{3} \mathrm{O}_{8}$ equivalent) and LEU with a ${ }^{235} \mathrm{U}$ content of 4.5 percent $\left(1.2\right.$ million pounds $\mathrm{U}_{3} \mathrm{O}_{8}$ and approximately 280,000 SWU) (Table 7). It is being stored by DOE at the enrichment plants in Paducah, Kentucky, and Portsmouth, Ohio.

DOE intended that revenues obtained from selling surplus U.S. uranium be applied to offset payments made in meeting commitments to upgrade and maintain the enrichment plants that it owns and leases to USEC. Congress, in its fiscal year 1997 appropriations authorization, anticipated that DOE would sell $\$ 42$ million of uranium in fiscal year 1997 and apply the revenues for such use. ${ }^{105}$ In addition, the sale would eliminate inventory holding costs. Before any material can be sold, however, the Secretary of Energy is required by the USEC Privatization Act to determine that "the sale of the material will not have an adverse material impact on the domestic uranium, conversion, and enrichment industries." 106 In addition, the Secretary's determinations must take into account the sales of uranium under the Russian HEU Agreement and the Suspension Agreement with Russia. Also, the price paid for the uranium must not be less than the fair market value established for the uranium.

The report, Environmental Assessment: DOE Sales of Surplus Natural and Low Enriched Uranium ${ }_{1}^{107}$ published by DOE in October 1996, provided an analysis of three reasonable disposition alternatives and a no action storage alternative regarding U.S. Government surplus commercial-grade uranium. The Preferred Alternative consists of: (1) sell all 20.3 million pounds $\mathrm{U}_{3} \mathrm{O}_{8}$ equivalent of natural uranium between 1996 and 2004 for domestic or foreign use after the Secretary's determination, and (2) sell all 1.2 million pounds $\mathrm{U}_{3} \mathrm{O}_{8}$ equivalent of LEU in 1996, if possible, after Secretarial determination (Table 7). No sales were made in 1996, because the Secretary's determination was not made during the year.

In January 1997, the Office of Nuclear Energy, Science and Technology announced the quantity and mechanism by which it planned to sell uranium during fiscal year 1997, ending on September 30, $1997 .^{108}$ It proposed to sell up to 3.2 million pounds $\mathrm{U}_{3} \mathrm{O}_{8}$ equivalent of natural

${ }^{101}$ U.S. Department of Energy, "Pena Doubles Amount of U.S. Plutonium and Highly Enriched Uranium Available for International Inspection," press release (Washington, DC, September 29, 1997).

${ }^{102}$ D. Tousley, personal correspondence, U.S. Department of Energy, Office of Fissile Materials Disposition (Washington, DC, November 18, 1997).

${ }^{103}$ U.S. Department of Energy, "International Agency Inspects U.S. Uranium Facility;Marks NuclearNonproliferation Milestone," press release (Washington, DC, December 1, 1997).

${ }^{104}$ U.S. Department of Energy, "Notice of Intent to Prepare an Environmental Assessment on the Proposed Sale of Surplus Natural and Low Enriched Uranium," in Federal Register, Vol. 61 (July 9, 1996).

${ }^{105}$ U.S. Department of Energy, Office of Nuclear Energy, Science and Technology, Environmental Assessments: DOE Sale of Surplus Natural and Low Enriched Uranium, DOE/EA-1172 (Washington, DC, October 1996), p. 1-1.

${ }^{106}$ Public Law 104-134, Balanced Budget Down Payment Act, Subchapter A-USEC Privatization Act, Section 3112 (d-Inventory Sales) (April 1992).

${ }^{107}$ U.S. Department of Energy, Office of NuclearEnergy, Science and Technology, Environmental Assessment: DOE Sale of Surplus Natural and Low Enriched Uranium, DOE/EA-1172 (Washington, DC, October 1996).

${ }^{108}$ R.M. George, "Status Report on DOE's Surplus Uranium Sales Program," speech presented at the Nuclear Energy Institute's Nuclear Fuel Supply Forum (Washington, DC, January 28, 1997). 
Table 7. Status of U.S. Department of Energy (DOE) Plans to Dispose of Surplus Commercial-Grade Natural Uranium and Low-Enriched Uranium (LEU), as of December 31, 1997

\begin{tabular}{|c|c|c|c|c|c|}
\hline $\begin{array}{l}\text { Sell DOE } \\
\text { Surplus } \\
\text { Natural } \\
\text { Uranlum } \\
\text { (as UF. } \text { U. }^{\mathrm{b}}\end{array}$ & 20.3 & $\begin{array}{l}\text { Sell all between } 1996 \text { and } 2004 \text { for } \\
\text { domestic or foreign end use after } \\
\text { Secretarial determination; for FY } 97^{c} \\
\text { not to exceed } 2.0 \text { million pounds if } \\
\text { all LEU is sold (see below). Total } \\
\text { sales of natural uranium and LEU } \\
\text { cannot exceed } 3.2 \text { million pounds } \\
\text { per year. }\end{array}$ & $\begin{array}{l}\text { March } 12,1997 \\
\text { sales authorized } \\
\text { for FY97. }\end{array}$ & $\begin{array}{l}\text { In August } 1997, \text { DOE invited } \\
\text { bids for } 1.0 \text { million pounds } \\
\mathrm{U}_{3} \mathrm{O}_{8} \text { equivalent and } 382,781 \\
\mathrm{~kg} \mathrm{U} \text { conversion for delivery } \\
\text { by September } 30,1999 \text {. } \\
\text { Contracts completed between } \\
\text { DOE and the winning bidders } \\
\text { during October } 1997 \text {. }\end{array}$ & $\begin{array}{l}\text { Natural uranium to be sold } \\
\text { as follows: } \\
\text { - Competifive sealed bids } \\
\text { - Uranium and conversion } \\
\text { components offered } \\
\text { separately } \\
\text { - Award to hlghest bldder } \\
\text { - If blds not adequate, } \\
\text { some uranium rould be } \\
\text { retained for later sale. }\end{array}$ \\
\hline $\begin{array}{l}\text { Sell } \\
\text { Russlan } \\
\text { HEU Feed } \\
\text { Transferred } \\
\text { to DOE } \\
\text { from USEC } \\
\text { (as UF } \text { ( }_{8}\end{array}$ & 14.2 & $\begin{array}{l}\text { Sell about half to Russia for use in } \\
\text { matched sales to domestic end } \\
\text { users (only } 2.7 \text { million pounds of } \\
\text { matched sales allowed in calendar } \\
1997 \text { ). Sell remaining material for } \\
\text { overfeeding, foreign end use, or in } \\
2001 \text { for domestic end use after } \\
2002 \text {. }\end{array}$ & Not required. & $\begin{array}{l}\text { DOE and Global Nuclear } \\
\text { Services and Supply (GNSS) } \\
\text { signed contract on December } \\
\text { 12, 1996; DOE to provide } \\
\text { GNSS with uranium for use in } \\
\text { matched sales. First delivery } \\
\text { made to GNSS on December } \\
30,1996 \text {. }\end{array}$ & \\
\hline $\begin{array}{l}\text { Transfer } \\
\text { DOE } \\
\text { Surplus } \\
\text { Natural } \\
\text { Uranlum to } \\
\text { USEC' (as } \\
\text { UF, ) }\end{array}$ & Up to 18.3 & Pending. & Not required. & None. & $\begin{array}{l}\text { Transfer to include } 50 \\
\text { metric tons HEU; total } \\
\mathrm{UF}_{6} \text { and HEU equivalent } \\
\text { to } 31.2 \text { million pounds. } \\
\text { - USEC not permitted to } \\
\text { sell transferred material } \\
\text { until January } 1,1998, \\
\text { only at a rate of } 10 \\
\text { percent per year not } \\
\text { exceeding } 4 \text { million } \\
\text { pounds (including HEU). }\end{array}$ \\
\hline
\end{tabular}

\footnotetext{
${ }^{a}$ The Secretary of Energy must determine that the sale of material will not have an adverse material impact on the domestic uranium mining, conversion, and enrichment industry pursuant to USEC Privatization Act (April 26, 1996), Section 3112 (d).

${ }^{b} \mathrm{UF}_{6}$ is the chemlcal formula for uranium hexafluoride; it is used as feedstock for producing LEU.

${ }^{c}$ FY97: Fiscal Year 1997 (October 1, 1996, to September 30, 1997).

dNatural uranium component of LEU derived from Russian HEU, transferred from the U.S. Enrichment Corporation (USEC) to the DOE pursuant to USEC Privatization Act (April 26, 1996), Section 3112 (b).

'Sales of Russian uranlum to U.S. end users must be matched with newly produced U.S.-origin uranium pursuant to the Amendment to the Suspension Agreement with the Russian Federation (March 11, 1994).

'DOE is directed to transfer to the U.S. Enrichment Corporation (USEC) without cost up to 7,000 metric tons of natural uranium and 50 metric tons of HEU pursuant to the USEC Privatization Act (April 26, 1996), Section 3112(c).

Sources: Sales of natural uranium and LEU-U.S. Department of Energy, Office of Nuclear Energy, Sclence and Technology, Environmental Assessment: DOE Sale of Surplus Natural and Low Enriched Uranium, DOE/EA-1172 (Washington, DC, October 1996); R.M. George, "Status Report on DOE's Surplus Uranium Sales Program," speech presented at the Nuclear Energy Institute's Nuclear Fuel Supply Forum (Washington, DC, January 28, 1997); U.S. Department of Energy, Determination Pursuant to the United States Enrichment Corporation Privatization Act for the Sale of Excess Department of Energy Uranlum During Fiscal Year 1997 (Washington, DC, March 12, 1997). Transfer of natural uranium to USEC-U.S. Department of Energy, Office of Fissile Materials Disposition, Disposition of Surplus Highly Enriched Uranium Final Environmental Impact Statement, DOE/EIS-0240-D (Washington, DC, June 1996); R. George, personal communication (Office of Nuclear Energy, Science and Technology, Germantown, MD, September 30, 1997).
} 
uranium and LEU through competitive bidding for minimum lots of 50,000 pounds. DOE would initiate the process by issuing a request for proposals asking interested parties to submit a sealed bid. The sale would be awarded to the highest bidder. Some uranium could be held if unacceptable bids were received. In addition, buyers would be given the option of bidding on the uranium's conversion component, separate from $\mathrm{U}_{3} \mathrm{O}_{8}$ or $\mathrm{UF}_{6}$. This separation of components recognizes that the introduction of surplus $\mathrm{UF}_{6}$ into the market could have a greater impact on the uranium conversion industry than on other nuclear fuel cycle industries. ${ }^{109}$ The plan moved closer to reality on March 12, 1997, when the Secretary of Energy determined that the proposed quantity could be sold in fiscal year 1997 without creating an adverse material impact on the domestic industry. ${ }^{110}$

The timing of the Secretary's determination coincided with a decline in the spot-market price for $\mathrm{U}_{3} \mathrm{O}_{8}$. By the end of March 1997, the price had fallen to $\$ 13.30$ per pound $\mathrm{U}_{3} \mathrm{O}_{8}$ from a high of $\$ 16.50$ per pound $\mathrm{U}_{3} \mathrm{O}_{8}$ in July 1996. ${ }^{111}$ Uranium suppliers expressed concern that DOE's initial plans to sell 3.2 million pounds $\mathrm{U}_{3} \mathrm{O}_{8}$ equivalent in fiscal year 1997 would further depress prices. ${ }^{112}$ DOE postponed the initiation of sales until August 1997, when it invited qualified interested parties to bid for up to 1.0 million pounds $\mathrm{U}_{3} \mathrm{O}_{8}$ equivalent as natural $\mathrm{UF}_{6}$ and $382,721 \mathrm{~kg} \mathrm{U}$ of conversion. ${ }^{113}$ This material would be available for delivery up to September 30,1999. DOE received qualified bids for the entire offering by September 30, 1997.

\section{DOE Sales of Russian HEU Feed}

The 1996 Notice of Intent also included a proposal to sell 14.2 million pounds $\mathrm{U}_{3} \mathrm{O}_{8}$ of Russian feed, in the form of natural $\mathrm{UF}_{6}$, transferred to DOE by USEC. This Russian feed is the natural uranium component of LEU derived from 18 metric tons of Russian HEU purchased by USEC during 1995 and 1996 as part of the Russian HEU
Agreement (see Chapter 4). Its transfer to DOE, completed in December 1996, was mandated by the USEC Privatization Act. ${ }^{114}$ DOE is authorized by the USEC Privatization Act to sell the Russian feed through one or a combination of four options: (1) at any time for use in the United States for the purpose of overfeeding enrichment plants, ${ }^{115}(2)$ at any time for end use outside the United States, (3) in 1995 and 1996 to the Russian Executive Agent at the purchase price for use in matched sales pursuant to the Suspension Agreement, or (4) in calendar year 2001 for consumption by end users in the United States not prior to January 1, 2002, in quantities not to exceed the equivalent of 3 million pounds $\mathrm{U}_{3} \mathrm{O}_{8}$ per year (Table 7). Revenues realized from the sale of Russian feed would go to the U.S. Treasury.

In the Environmental Assessment, DOE proposed to sell about 50 percent of the material to the Russian Executive Agent. In December 1996, DOE and Global Nuclear Services and Supply (GNSS), representing the Russian Executive Agent, signed a contract for the sale of a portion of the Russian feed during fiscal year 1997 for use in matched sales in the United States. ${ }^{116}$ The first delivery was made to GNSS on December 30, 1996, at a price of $\$ 28.50$ per $\mathrm{kg} \mathrm{U}$ as $\mathrm{UF}_{6}$. This price is equivalent to $\$ 8.65$ per pound $\mathrm{U}_{3} \mathrm{O}_{8}$ for the uranium component.

\section{DOE Transfer to USEC Pursuant to the USEC Privatization Act}

In addition to natural uranium and LEU intended for sale, DOE has been directed by the USEC Privatization Act to transfer to USEC without charge up to 7,000 metric tons of natural uranium, equivalent to 18.3 million pounds of $\mathrm{U}_{3} \mathrm{O}_{8}$. For purposes of minimizing the market impact of DOE transfers to USEC, the USEC Privatization Act places in the same pool transfers of both natural uranium and the 50 metric tons of HEU described on page 32. USEC is not permitted to sell uranium from the DOE transfers until January 1,1998,

\footnotetext{
${ }^{109}$ The USEC Privatization Act provides that Secretarial determinations will take into account sales of uranium under the Russian HEU Agreement and the Suspension Agreement. Unlike $\mathrm{U}_{3} \mathrm{O}_{8}$, the sale of the conversion component of LEU derived from Russian HEU has not been limited by schedules or quotas.

${ }^{110}$ U.S. Department of Energy, Office of the Secretary, Determination Pursuant to the United States Enrichment Corporation Privatization Act for the Sale of Excess Department of Energy Uranium During Fiscal Year 1997 (Washington, DC, March 12, 1997).

111 The Exchange Value as reported in TradeTech, The Nuclear Review (July 1997).

${ }^{112}$ The Ux Weekly, "DOE's Determination?" (March 17, 1997), p. 1.

${ }^{113}$ Commerce Business Daily (August 5, 1997).

${ }_{114}$ Public Law 104-134, Balanced Budget Down Payment Act, Subchapter A-USEC Privatization Act, Section 3112(b) (April 1992).

${ }^{115}$ Overfeeding involves using more relatively less expensive uranium to produce the same quantity of enriched product with less relatively more expensive power.

${ }^{116}$ R.M. George, “Status Report on DOE's Surplus Uranium Sales Program," speech presented at the Nuclear Energy Institute's Nuclear Fuel Supply Forum (Washington, DC, January 28, 1997).
} 
and then only at a rate of 10 percent a year while not exceeding 4 million pounds $\mathrm{U}_{3} \mathrm{O}_{8}$ equivalent. DOE's Office of Fissile Materials Disposition has included an assessment of this action as part of its overall assessment of HEU disposition.

\section{Plutonium}

\section{Surplus Inventory Characterization}

DOE has officially declared 38.2 metric tons of U.S. weapons-grade plutonium as surplus. ${ }^{117}$ This plutonium is equivalent to about 17 million pounds of $\mathrm{U}_{3} \mathrm{O}_{8}{ }^{118}$ Other inventories are expected to increase the quantity of U.S. Government surplus plutonium to approximately 50 metric tons. ${ }^{119}$ Of the 50 metric tons of plutonium identified as surplus, 31.8 metric tons are metal contained in components of dismantled nuclear weapons, called "pits," or in other forms. ${ }^{120}$ The remainder of the inventory contains impure metal alloys, various oxides, and reactor fuel. DOE has adopted the term "weaponsusable" to characterize its surplus plutonium inventories. To meet the President's nonproliferation policy, DOE is required to dispose of surplus weapons-usable plutonium in a proliferation-resistant fashion. Also, the surplus plutonium, including that coming from dismantled weapons, will be made available for IAEA inspection. To be available for inspection, pits will have to be disassembled and converted to unclassified forms.

\section{Development of Plutonium Disposition Alternatives}

Unlike HEU, which can be readily converted to proliferation-resistant LEU, the disposition of separated plutonium is much more difficult. The difficulty arises because the fissile isotopes of plutonium cannot be blended down into a commercial form unusable for the manufacturing of weapons. In a U.S. Government- commissioned study completed in 1994, the National Academy of Sciences (NAS) advanced the position that the disposition of surplus weapons-grade plutonium should result in plutonium being made roughly as inaccessible for weapons use as the much larger and growing quantity that exists in spent fuel from commercial reactors. ${ }^{121}$ The NAS concluded that two alternatives used in parallel would provide a reasonable approach for meeting its "spent fuel standard." The two alternatives, each requiring the conversion of plutonium metal into oxide, are: (1) immobilization into chemically stable forms suitable for disposal in a geologic repository (immobilization alternative) and (2) fabrication into MOX fuel that will be irradiated in commercial nuclear power reactors (reactor alternative). Subsequent studies by the American Nuclear Society (1995) and the U.S.Russian Independent Scientific Commission on Disposition of Excess Weapons Plutonium (1997) have supported the NAS position. ${ }^{122,123}$

The reactor alternative is based on commercially established technologies that have been used for many years in Western Europe and Japan (see Chapter 2). To accelerate the timetable for disposition while other facilities are being developed, the U.S.-Russian Independent Scientific Commission recommended existing European MOX fuel fabrication plants for producing initial fuel batches of weapons-plutonium MOX to be irradiated in U.S. and Russian reactors. ${ }^{124}$ The irradiation of weapons plutonium in commercial nuclear power reactors would be limited to a "once-through" fuel cycle, in which the discharged spent fuel would not be reprocessed but rather disposed of in a geologic repository. Although the irradiation of MOX fuel would not burn up all of the contained plutonium, the fissile plutonium would be diluted with newly generated nonfissile plutonium isotopes. The high radiation emitted from fission products forms a radiation barrier to protect the plutonium remaining in discharged spent fuel from diversion. Recovery of fissile plutonium from

\footnotetext{
${ }^{117}$ U.S. Department of Energy, Record of Decision for the Storage and Disposition of Weapons-Usable Fissile Materials Final Programmatic Environmental Impact Statement (Washington, DC, January 14, 1997), Footnote 1, p. 2.

${ }^{118}$ The Uranium Institute, The Recycling of Fissile Nuclear Materials, Final report of the recycling working group (London, November 1996), p. 44.

${ }^{119}$ U.S. Department of Energy, Office of Fissile Materials Disposition, General Requirements Document, DOE/MD-007 (Washington, DC, October 1, 1996), p. 2-4.

${ }^{120}$ Metal considered as "pure" can contain from trace up to 1 percent impurities.

${ }^{121}$ National Academy of Science, Committee on International Security and Arms Control, Management and Disposition of Excess Weapons Plutonium, National Academy Press (Washington, DC, January 24, 1994).

${ }^{122}$ American Nuclear Society, Protection and Management of Plutonium, Report of The Special Panel on the Protection and Management of Plutonium (La Grange Park, Illinois, August 1995).

${ }^{123}$ Final Report of the U.S.-Russian Independent Scientific Commission on Disposition of Excess Weapons Plutonium, June 1, 1997, released by The White House Office of Science and Technology (Washington, DC, September 10, 1997).

${ }^{124}$ Ibid; p. 2.
} 
spent fuel would require substantial resources and technology.

\section{DOE's Dual-Track Strategy for Plutonium Disposition}

In June 1994, DOE published a Notice of Intent to prepare a programmatic environmental impact statement for the storage and disposition of weapons-usable fissile materials (S\&D PEIS). ${ }^{125}$ The S\&DPEIS considered variants of the immobilization and reactor alternatives as well as a deep borehole alternative, advanced by NAS for plutonium disposition. ${ }^{126}$ Furthermore, DOE adopted the NAS spent fuel standard in developing a mission to render surplus plutonium "as unattractive and inaccessible for retrieval and weapons use as the residual plutonium in the spent fuel from commercial reactors." 127 The S\&D Final PEIS, published in December $1996,{ }^{128}$ provided for a dual-track disposition strategy using the immobilization and reactor alternatives, while reserving the option to immobilize all surplus plutonium (Figure 4). To be amenable for these disposition alternatives, the surplus plutonium would first be converted into plutonium oxide $\left(\mathrm{PuO}_{2}\right)$. DOE indicated that the timing and extent of implementing the alternatives are dependent on a variety of factors, including the demonstration of technologies, site-specific environmental assessments, cost reviews, contract negotiations, and agreements with Russia and other countries.

In January 1997, DOE released its Record of Decision (ROD) that sets forth decisions on the programmatic strategies advanced in the S\&D Final PEIS. ${ }^{129}$ DOE estimated that implementation of its dual-track strategy would cost approximately $\$ 2.2$ billion in 1996 dollars. ${ }^{130}$ This estimated cost is net of potential cost recoveries from the reduction of purchases of conventional LEU by nuclear power generating companies participating in the reactor alternative, estimated by DOE to be $\$ 930$ million over the life of the program. ${ }^{131}$

\section{Immobilization Alternative}

According to the ROD, DOE plans to immobilize at least 8 metric tons of surplus plutonium that would not be acceptable for use in MOX fuel without extensive purification. To date, immobilization of plutonium has not been demonstrated on an industrial scale. In October 1997, a technology to process impure plutonium oxides into a ceramic form was recommended over an alternate technology that would have produced a glass form. ${ }^{132}$ To make the plutonium more proliferation resistant, high-level radioactive waste is to be poured around the immobilized material to achieve an intense radiation barrier. All immobilized plutonium would be encased in stainless steel canisters and would remain at the processing site until a permanent high-level waste repository becomes available. When combined with commercial spent fuel at a high-level waste repository, the immobilized former weapons-usable plutonium would be under safeguards and security comparable to those of commercial nuclear fuel. Thus, immobilization produces an outcome that falls under the spent fuel standard. In planning to immobilize a portion of the surplus plutonium, DOE would make less plutonium available to manufacture MOX fuel for commercial nuclear power reactors.

\section{Reactor Alternative}

In the ROD, a decision was made to irradiate some of the surplus plutonium as MOX fuel in existing, domestic, commercial reactors. A plant for fabricating MOX fuel would be operated on a DOE site only for the surplus plutonium disposition program. The exact location for the MOX fabrication plant would be

\footnotetext{
${ }^{125}$ Federal Register (June 21, 1994).

${ }^{126}$ The deep borehole alternative consists of using boreholes to emplace plutonium permanently into deep stable rock formations. No radiation barriers would be added.

${ }^{127}$ U.S. Department of Energy, Office of Fissile Materials Disposition, Technical Summary Report for Surplus Weapons-Usable Plutonium Disposition, DOE/MD-003 (Washington, DC, July 17, 1996), p. 1-1.

${ }^{128}$ U.S. Department of Energy, Office of Fissile Materials Disposition, Storage and Disposition of Weapons-Usable Fissile Materials Final Programmatic Statement, DOE/EIS-0229 (Washington, DC, December 1996).

${ }^{129}$ U.S. Department of Energy, Record of Decision for the Storage and Disposition of Weapons-Usable Fissile Materials Final Programmatic Environmental Impact Statement (Washington, DC, January 14, 1997).

${ }^{130}$ Ibid, p. 19.

${ }^{131}$ U.S. General Accounting Office, Nuclear Nonproliferation and Safety: Uncertainties About the Implementation of U.S.-Russian Plutonium Disposition Efforts, Report to the Chairman, Committee on Foreign Relations, U.S. Senate, GAO/RCED-98-16 (Washington, DC, January 1998), Figure 3.

${ }^{132}$ S.G. Cochran, W.H. Dunlop, T.A. Edmunds, L.M. MacLean, and T.H. Gould, Fissile Material Disposition Program Final Immobilization Form Assessment and Recommendation, UCRL-ID-128705 (Lawrence Livermore National Laboratory, October 3, 1997 ), p. 1.
} 
Figure 4. Relationship of the U.S. Department of Energy's Surplus Plutonium Disposition Alternatives and the Civilian Nuclear Fuel Cycle

U.S. Department of Energy's Surplus Plutonium Disposition Alternatives

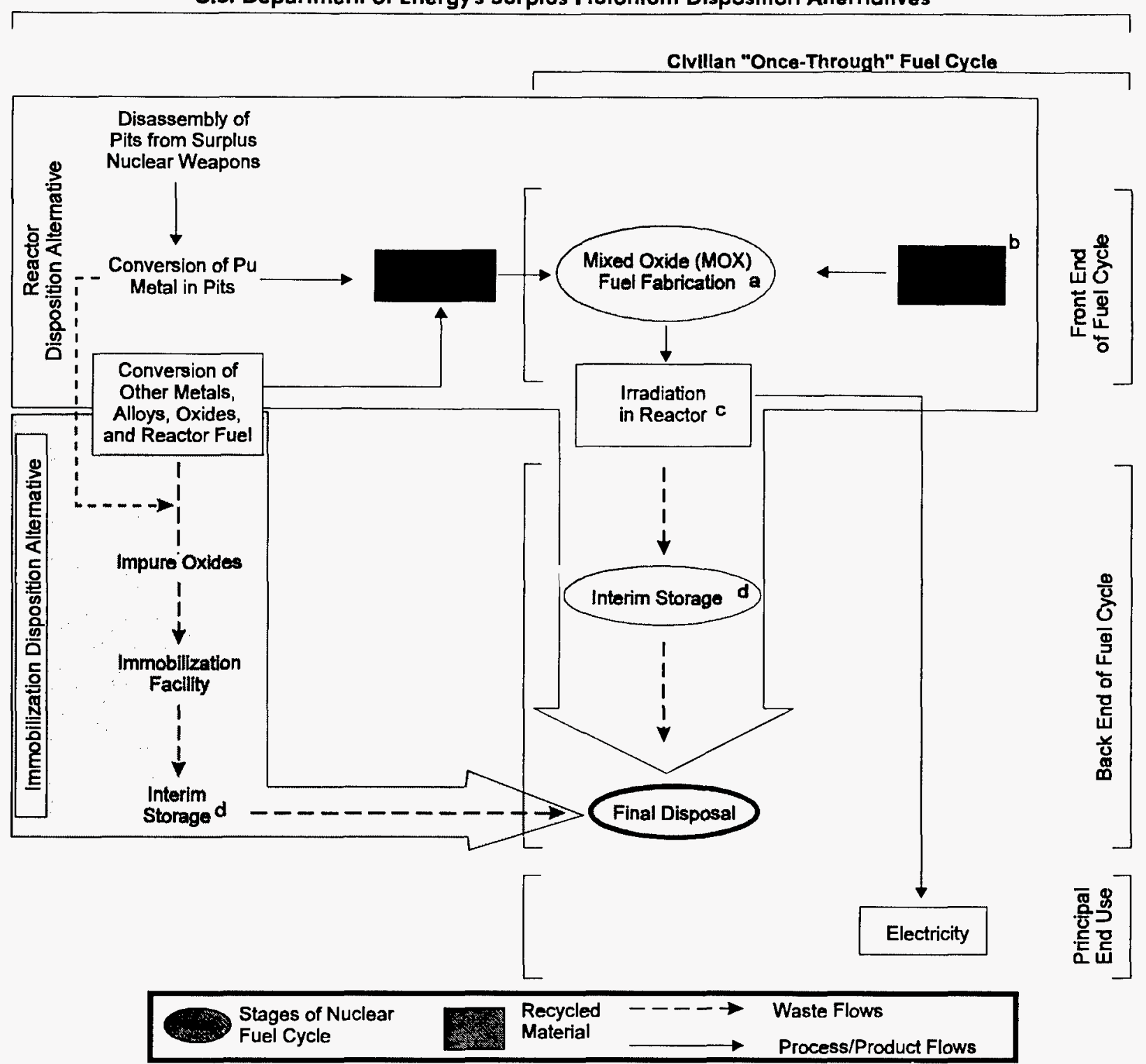

${ }^{a}$ MOX fuel fabrication plant on a U.S. Department of Energy site to be operated by a commercial consortium only for the disposition of weapons-usable plutonium.

Depleted uranium, generated by the U.S. Government's former uranium enrichment program, wil be used as a feed for MOX fuel.

${ }^{c}$ Existing light-water reactors in the United States and Canadian deuterium-uranium (CANDU) reactors in Canada are considered as options for the irradiation of MOX fuel.

${ }^{\mathrm{d}} \mathrm{High}-\mathrm{level}$ radioactive waste is to be stored at interim sites pending completion of a permanent geologic repository.

$\mathrm{Pu}=$ Plutonium.

$\mathrm{PuO}_{2}=$ Plutonium oxide.

Source: Energy Information Administration, Office of Coal, Nuclear, Electric and Alternate Fuels. 
determined later. By owning and controlling the plant site, DOE would follow U.S. Government policy, which discourages the civilian use of plutonium. The irradiation of MOX fuel would be limited to a once-through fuel cycle with the resulting discharged spent fuel disposed of in a geologic repository.

To irradiate MOX fuel, DOE had considered four types of reactors: (1) existing commercial light-water reactors, (2) commercial light-water reactors on which construction was halted, which would be completed, (3) evolutionary light-water reactors (improved variants of existing designs) that would be built at a DOE site, ${ }^{133}$ and (4) existing Canadian deuterium-uranium (CANDU) reactors. For domestic reactors, the modification of operating licenses for commercial reactors to burn MOX fuel will be required. The use of MOX fuel will be limited to the disposition of surplus weapons-usable plutonium. To ensure that specific reactor types and ownership could be properly analyzed, a number of reactor and core design parameters had to be identified. A detailed description of the technical parameters for the reactor alternative is presented in the report by the Office of Fissile Materials Disposition entitled, Technical Summary Report for Surplus Weapons-Usable Plutonium Disposition. ${ }^{134}$

The reactor alternative also has been considered as an option to ensure the mutual disposition of U.S. and Russian weapons plutonium. At the Moscow Nuclear Safety and Security Summit in April 1996, the Group of Seven Industrialized Nations, including the United States, along with Russia adopted the spent fuel standard. Following the Moscow summit, the Government of Canada agreed in principle to the concept of using Canadian reactors for the disposition of weapons plutonium. Canadian government policy does not exclude the use of plutonium as reactor fuel. Because campaigns to irradiate weapons plutonium are not expected to begin at U.S. or Russian reactors before 2003 , the availability of CANDU reactors could present an opportunity for implementing a reciprocal disposition campaign with Russia at an earlier date. ${ }^{135}$ To assess the feasibility of a possible cooperative agreement with Canada and Russia, DOE is working with the Canadian government and nuclear industry to test a small quantity of MOX fuel at a Canadian research reactor. ${ }^{136}$ Should an agreement be reached, DOE would modify its disposition plans to include the CANDU option.

\section{Status of the Reactor Alternative as of December 31, 1997}

To remain in the scope of this report, the following description of the current status of DOE's plutonium disposition activities is limited to the reactor alternative. In May 1997, DOE published a Notice of Intent to prepare an EIS to examine reasonable alternatives and potential environmental impacts as required by the NEPA process for the proposed siting, construction, and operation of three types of facilities for surplus plutonium disposition. ${ }^{137}$ The facilities to be considered are for: (1) conversion of pits into $\mathrm{PuO}_{2},(2)$ immobilization of impure plutonium oxides into glass or ceramic form, and (3) fabrication of $\mathrm{PuO}_{2}$ into MOX fuel. Siting for a MOX fuel fabrication plant was considered for the following DOE facilities: Hanford Reservation, Washington; Pantex Plant, Amarillo, Texas; Idaho National Engineering and Environmental Laboratory, Idaho; and Savannah River site, South Carolina. The proposed EIS follows the Record of Decision for the Storage and Disposition of Weapons-Usable Fissile Materials PEIS (Appendix C, Table C1). Detailed assessments of potential sites for disposition facilities had not been made in previous statements.

As a preliminary step in procuring potential MOX fuel fabrication and reactor irradiation services from the private sector, the Office of Fissile Materials Disposition released a program acquisition strategy (PAS) in July 1997. ${ }^{138}$ The PAS describes DOE's approach and solicits comments from prospective offerors. Comments regarding the PAS will be used in preparing a draft Request for Proposals (RFP), which was scheduled for

\footnotetext{
${ }^{133}$ Evolutionary reactors are also known as advanced light-water reactors.

${ }^{134}$ U.S. Department of Energy, Office of Fissile Materials Disposition, Technical Summary Report for Surplus Weapons-Usable Plutonium Disposition, DOE/MD-0003 (Washington, DC, July 17, 1996).

${ }^{135}$ MOX fuel fabricated from weapons plutonium is not expected to be available for initial lead assembly loadings until 2003 in Russia and 2004 in the United States.

${ }^{136}$ U.S. Department of Energy, Office of Fissile Materials Disposition, Program Acquisition Strategy for Obtaining Mixed Oxide Fuel Fabrication and Reactor Irradiation Services (PAS) (Washington, DC, July 17, 1997), p. 1.

${ }^{137}$ U.S. Department of Energy, "Notice of Intent Surplus Plutonium Environmental Impact Statement," in Federal Register (May 22, 1997), pp. 28009-28014.

${ }^{138}$ U.S. Department of Energy, Office of Fissile Materials Disposition, Program Acquisition Strategy for Obtaining Mixed Oxide Fuel Fabrication and Reactor Irradiation Services (PAS) (Washington, DC, July 17, 1997).
} 
issuance in final form to potential offerors in early 1998 (Table 8). DOE expects to award a contract in September 1998. However, DOE will not construct or operate a MOX fuel fabrication facility or irradiate MOX fuel in a commercial reactor until such activities are approved in the pending "Record of Decision for Surplus Plutonium Disposition."

As described in the PAS, DOE requests that both integrated MOX fuel fabrication and reactor irradiation services be provided by a single consortium. The single consortium is believed to offer two advantages: (1) encouraging relationships between fuel fabricators, engineering firms, and nuclear reactor operators, and (2) simplifying DOE's selection and contracting processes by awarding one contract. In addition to fuel fabrication and irradiation services, the consortium would be expected to design the MOX fuel, modify reactors to accommodate MOX fuel, provide architectural and engineering services, and obtain licensing of the MOX fuel fabrication plant from the Nuclear Regulatory Commission. The PAS also provided the qualifying criteria for each of the required activities. The U.S. Government would provide the following materials and services: (1) depleted uranium $\left(\mathrm{UF}_{6}\right.$ or $\left.\mathrm{UO}_{3}\right)$, if desired; (2) $\mathrm{PuO}_{2}$; (3) fuel fabrication facility at DOE site; (4) transportation of $\mathrm{PuO}_{2}$ to fuel fabrication site; (5) transportation of fuel to reactors for irradiation; (6) acceptance of certain wastes; and (7) certified package for transportation of fresh MOX fuel.

As a technical baseline for planning purposes, 33 metric tons of plutonium are expected to be converted to $\mathrm{PuO}_{2}$ feed for MOX fuel fabrication. ${ }^{139}$ To enure proper MOX fuel fabrication, gallium may have to be removed from $\mathrm{PuO}_{2}$ derived from pits. ${ }^{140,141}$ Nevertheless, DOE plans

Table 8. U.S. Department of Energy's (DOE) Schedule for Implementing the Reactor Alternative to Dispose of Surplus Weapons-Usable Plutonium

\begin{tabular}{l|l|l}
\hline \multicolumn{1}{c|}{ Date } & \multicolumn{1}{c}{ Planned Action } & \multicolumn{1}{c}{ Comments } \\
\hline $\begin{array}{l}\text { February } 1998 \\
\text { (see note) }\end{array}$ & Issue Request for Proposals. & $\begin{array}{l}\text { To acquire MOX fuel fabrication and reactor irradiation } \\
\text { services preferably from a private sector consortium }\end{array}$ \\
& & that must include either a U.S.-owned reactor licensee \\
& or a U.S.-owned nuclear steam supply system vendor.
\end{tabular}

May 1998 (see note) Proposals due from offerors.

September $1998 \quad$ Award contract.

2001

DOE to make first plutonium from weapons dismantlement available to produce MOX fuel for lead assembly demonstration or production operation.

At least 0.5 metric ton $\mathrm{PuO}_{2}$. Lead assembly refers to the initial loading of MOX fuel into the core of a reactor.

DOE to increase plutonium availability.

2007

2022
Deadline for irradiation to commence at commercial reactors.
1.0 metric tons $\mathrm{PuO}_{2}$ feed by the beginning of 2004, approximately 3.5 metric tons per year in subsequent years.

MOX fuel core reloads, assumes that lead assembly demonstrations have already taken place.

After the campaign ends, MOX fuel production and irradiation to end in the United States.

Note: Based on original schedule. A Request for Proposals had not been issued as of April 30, 1998.

Sources: U.S. Department of Energy, Office of Fissile Materials Disposition, Program Acquisition Strategy for Obtaining Mixed Oxide Fuel Fabrication and Reactor Irradiation Services (PAS) (Washington, DC, July 17, 1997).

${ }^{139}$ Ibid, p. A-2.

${ }^{140}$ Small quantities of gallium, a metallic element, are alloyed with plutonium metal during the manufacture of pits.

141 "DOE MOX Implementation Plan Puzzles Industry and Critics Alike," NuclearFuel (July 28, 1997), pp. 4-5. 
to make at least 0.5 metric ton of $\mathrm{PuO}_{2}$ from weapons dismantlement available by the beginning of 2001 for lead assembly (initial reactor fuel loading) demonstration or production operation (Table 8). An assumed rate of approximately 3.5 metric tons per year is to be maintained after 2004.

To meet uranium feed requirements for MOX fuel fabrication, DOE is planning to provide depleted uranium either as $\mathrm{UF}_{6}$ or $\mathrm{UO}_{3}$ to the consortium at no cost. This supply would come from existing DOE inventories, such as $\mathrm{UF}_{6}$ held at the Paducah, Portsmouth, and K-25 enrichment plant sites (see Chapter 3 ). The consortium is not permitted under most conditions to either acquire depleted uranium from other sources or process the depleted uranium into feed outside of existing, licensed U.S. facilities. However, the consortium can choose to acquire uranium at enrichment levels different from those of depleted uranium at its own cost.

DOE requests that the irradiation of MOX fuel derived from weapons-usable plutonium begin no later than 2007 and end in 2022 (Table 8). To meet this schedule, the consortium must provide a minimum of three and a maximum of eight operating reactors that can complete the mission within remaining licenses. DOE will consider only reactors located in the United States licensed to at least 2012. The burnup of MOX fuel is to exceed a minimum of 20,000 megawattdays thermal per metric ton of initial heavy metal (MWDT/MTIHM). Higher burnups within the operating experience of MOX-fueled European reactors are preferred to minimize spent fuel discharges. ${ }^{142}$ All spent fuel must be amenable to storage and disposal pursuant to the Nuclear Waste Policy Act.

${ }^{142}$ EIA uses the following average burnup rates for MOX-fueled reactors in developing projections for uranium requirements and spent fuel: boiling-water reactors, 39,000 MWDT/MTIHM; pressurized-water reactors, 46,800 MWDT/MTIHM. 


\section{Market Effects}




\section{Analysis of Market Penetration Factors}

Plans for converting U.S. and Russian surplus defense inventories into fuel for commercial nuclear power plants have been described in the two preceding chapters. The realization of such a goal is dependent on factors related to both the ability of the governments to meet the plans and the dynamics of the commercial marketplace. This chapter provides an analysis of the key factors that could influence the ultimate market penetration of uranium derived from U.S. and Russian surplus defense inventories.

Based on approved disposition plans for U.S. and Russian surplus defense inventories, the equivalent of 474 million pounds $\mathrm{U}_{3} \mathrm{O}_{8}$ is expected to be made available for use in commercial nuclear fuel over the next 15 to 20 years. This quantity exceeds the reserves of any one of the world's major new uranium mines scheduled to begin production during the next several years (Figure 5). Assuming that the schedules described in previous chapters will be met, the annual rate for commercializing surplus defense inventories would exceed the equivalent of 30 million pounds $\mathrm{U}_{3} \mathrm{O}_{8}$ by 1999 (Figure 6). In comparison, the largest mining projects under development, Cigar Lake and McArthur River in Canada, are each scheduled to produce as much as 18 million pounds of $\mathrm{U}_{3} \mathrm{O}_{8}$ per year for at least 15 years.

The LEU that would be made available for commercial use contains 102 million SWU of enrichment. On an annual basis, increased commercialization is expected to yield more than 6 million SWU by 1999 (Figure 7). The sale of LEU from surplus defense inventories would displace the need for enrichment services normally required to produce an equivalent amount of LEU from natural uranium. For example, USEC has filled certain enrichment service contracts since 1995 with LEU blended down from Russian HEU. Under such an arrangement, USEC would charge customers for the SWU contained in the delivered LEU but would avoid using its own enrichment production capacity.

Proposed plans for disposing of weapons-grade plutonium include an option for burning MOX fuel in commercial reactors. If approved, the implementation of the U.S. disposition program by the end of the next decade could result in the displacement of 1 to 2 million pounds $\mathrm{U}_{3} \mathrm{O}_{8}$ per year. The plutonium would not be sold in a commercial market but rather supplied directly to reactors that are under contract to DOE (see Chapter 5). The nuclear power generating company would be part of a larger consortium of companies responsible for providing integrated services, including MOX fuel fabrication, to DOE.

\section{Figure 5. Comparison of the Uranium Reserves of Major Mining Projects and the Uranium Contained in U.S. and Russian Surplus Defense Inventories Currently Scheduled for Commercialization}

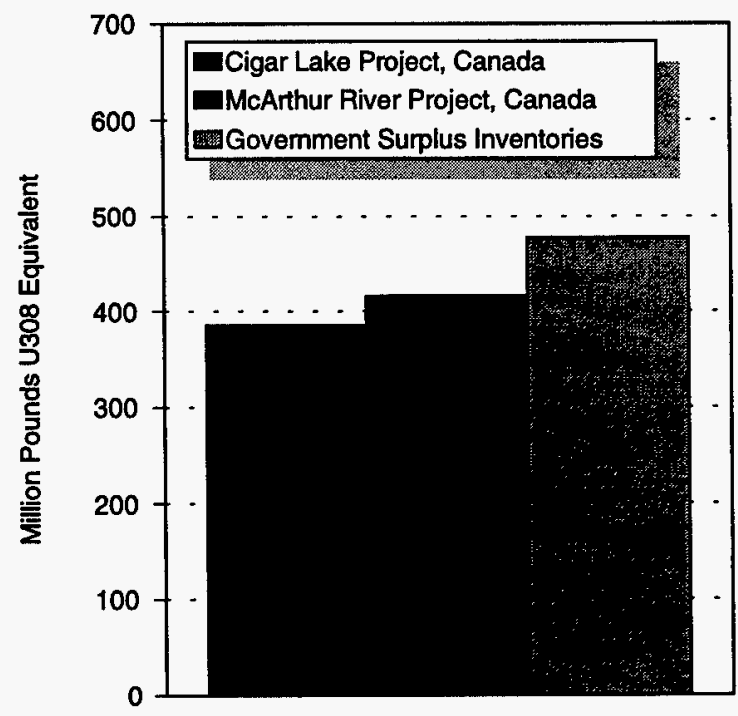

Explanation: Reserves are reported as "geological"; they are estimates of uranium contained in the ground and do not consider losses due to mining or milling; surplus defense inventories include Russian HEU and U.S. HEU, natural uranium, and LEU.

Sources: Mining projects-Cigar Lake Mining Corporation, The Cigar Lake Project Environmental Impact Statement (Executive Summary) (Saskatoon, Canada, July 1995), p. 3; The McArthur River Project Environmental Impact Statement (Executive Summary) (Saskatoon, Canada, November 1995), p. 3. Surplus defense inventories-Russian HEU Agreementand U.S. Department of Energy plans to dispose of HEU, LEU, and natural uranium. 
Figure 6. Potential Market Availability of Uranium Derived from U.S. and Russian Surplus Defense Inventories Currently Scheduled for Commercialization, 1997-2010

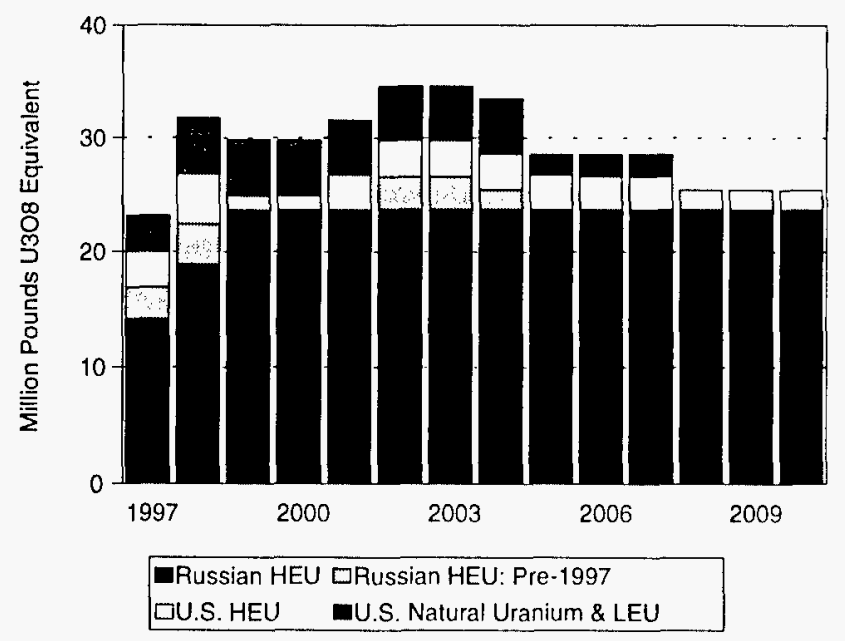

Explanation: Russian HEU: Pre-1997-Uranium feed component of Russian LEU derived from HEU transferred to the U.S. Department of Energy (DOE) by the United States Enrichment Corporation in 1996. DOE is authorized by the USEC Privatization Act to sell this uranium.

Sources: Russian HEU-Russian HEU Agreement. U.S. HEU, natural uranium, and LEU-U.S. Department of Energy disposition plans; United States Enrichment Corporation, 1996 Annual Report.

The ultimate penetration of surplus defense inventories into the market is indicated by deliveries from suppliers to nuclear power generating companies. It can be constrained by a number of factors that are considered to fall into the following two categories: (1) programmatic and (2) supply and demand. While it is likely that commercialization of surplus inventories will retain the support of the U.S. and Russian governments, it is not clear that current schedules can be met. Programmatic constraints include the technical, regulatory, political, and contractual factors that could affect the timely realization of the government programs. Once released to the marketplace, products are subject to the supply and demand constraints. Supply and demand constraints include projected declines in nuclear power generation capacity in the United States and Western Europe, national policies toward trade and security of supply, competing supplies, utility procurement practices, and supplier marketing strategies.

Because plutonium would not be sold in a market, the realization of the reactor option for disposition depends only on programmatic factors. In view of the assessment of programmatic and supply and demand constraints
Figure 7. Potential Market Availability of Enrichment Derived from U.S. and Russian Surplus Defense Inventories Currently Scheduled for Commercialization, 1997-2010

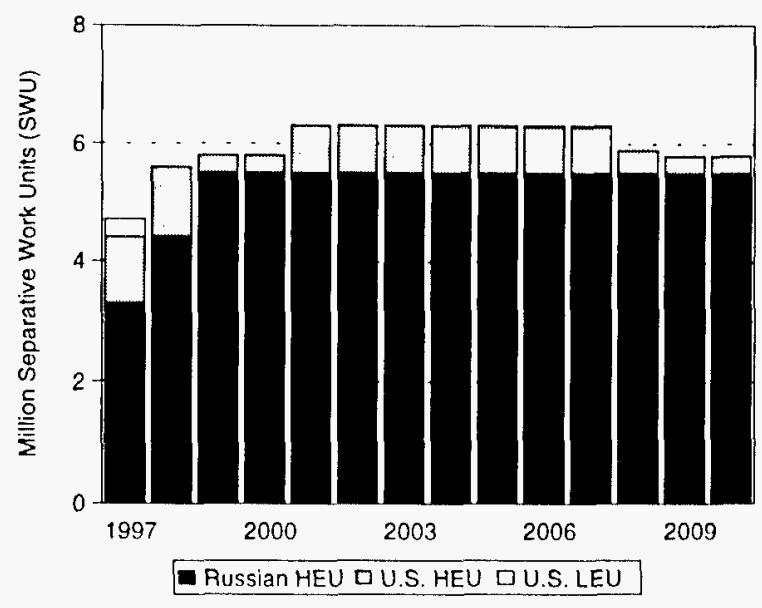

Sources: Russian HEU-Russian HEU Agreement, U.S. HEU and LEU-U.S. Department of Energy disposition plans; United States Enrichment Corporation, 1996 Annual Report.

provided below, the actual market penetration of U.S and Russian surplus defense inventories is expected to lag behind current government plans for commercialization.

A third factor-the extent to which the uranium feed component of LEU produced from Russian HEU (Russian feed) is made available to Western consumers as a result of decisions by the Russian government-combines certain aspects of the two broad categories. Because of its large potential impact on the nuclear fuel market, a discussion of the possible Russian utilization of Russia HEU feed is treated as a separate topic.

\section{Programmatic Factors}

\section{Russian HEU}

The commercialization of Russian HEU could be constrained by inadequate capacity or contractual differences related to the Russian HEU Agreement. Russia was able to resolve initial technical problems in blending Russian HEU into LEU to meet commercial specifications (see Chapter 4). The quantity of LEU delivercd to USEC in 1996 exceeded contractual obligations by 20 percent; however, the November 1996 amendment to the Russian HEU Agreement provided for deliveries to 
double by 1998 . To meet this increased delivery requirement, capacities would have to be expanded for dismantling nuclear weapons, purifying and blending down HEU, and supplying blendstock. In addition to the enrichment of "clean" tails, Russia could utilize the Russian feed returned to it by USEC as blendstock. ${ }^{143}$ Because the Russian HEU Agreement is strongly driven by U.S. nonproliferation policy and Russia's financial needs, both parties are expected to cooperate in resolving unanticipated problems. As has been done in the past, the Russians could be paid in advance for product by USEC or receive technical and financial assistance from the U.S. Government.

The current contract pursuant to the November 1996 amendment to the Russian HEU Agreement runs through 2001. One or both of the Executive Agents could take an aggressive stand on pricing or quantity to be delivered that might delay the completion of an agreement. This situation could result in a disruption of supply and an increase in price. Recent commentary has suggested that a privatized USEC might not be interested in pursuing the Russian HEU Agreement to the fullest extent because of economic considerations. ${ }^{144}$ Nevertheless, the U.S. and Russian governments would be expected to intercede, if necessary, to ensure a contract extension.

The sale of the feed component of LEU derived from Russian HEU (Russian feed) has added an additional dimension to the commercialization of Russian HEU. Because the Russian government had linked the delivery of LEU with the sale of Russian feed (see Chapter 4), the availability of both SWU and natural uranium in the commercial market are dependent on concluding the Russian HEU Agreement and selling the uranium feed component. With the suspension of negotiations between MINATOM and Western suppliers, Russia will apparently sell the Russian feed. ${ }^{145}$ Nevertheless, Russia has not indicated the amount of Russian feed that would be made available for Western consumption. A more detailed assessment of Russian feed availability is presented in a later section of this Chapter.

\section{U.S. Commercial-Grade Uranium}

In the fiscal year ending September 30, 1997, DOE was permitted to sell natural $\mathrm{UF}_{6}$ and LEU after the Secretary of Energy determined that such sales would not adversely affect the domestic uranium industry. However, future sales of such commercial-grade uranium also would require similar determinations. To facilitate sales, DOE is working on expanding the Secretary's determination to cover a multi-year period. Nevertheless, the condition of approval by the Secretary of Energy adds uncertainty to the availability of commercial-grade uranium from DOE.

\section{U.S. HEU}

The availability of LEU derived from U.S. HEU depends on the completion of several programmatic milestones. While the USEC Privatization Act provided for DOE's transfer of HEU to USEC, a Memorandum of Agreement to initiate the transfer of 50 metric tons of HEU along with 7,000 metric tons of natural uranium was not signed by the two parties until April 1998. ${ }^{146}$ For blending down HEU to LEU, USEC requires the services of a contractor. USEC is permitted by the USEC Privatization Act to deliver up to 4 million pounds $\mathrm{U}_{3} \mathrm{O}_{8}$ equivalent per year from this material beginning in 1998 (see page 33). Deliveries of the enrichment services component of HEU-derived LEU are limited to 800,000 SWU per year, beginning in 1998. Because the HEU must be blended down after the transfer has been completed, the resultant LEU might not be made available for an extended period. Nevertheless, USEC could choose to meet the quota for 1998 by selling the transferred natural uranium, which requires no further conversion.

The TVA's utilization of LEU derived from off-specification HEU is contingent on the results of a lead fuel assembly demonstration scheduled for 1999. Such a demonstration would indicate any technical or licensing problems. Until the lead fuel assembly demonstration has been completed, considerable uncertainty exists as to the quantities of HEU that can be used and the scheduling for reloading fuel derived from HEU into the reactors.

\section{U.S. Plutonium}

The plan to burn surplus weapons-usable plutonium in commercial nuclear power reactors is the least certain of all DOE disposition programs. Its implementation

\footnotetext{
${ }^{143}$ The availability of a blendstock from enriching tails low in U-234 and U-236 could be constrained by the availability of Russian enrichment capacity that has not been contaminated by reprocessed uranium.

144 "Mishandling Russian Uranium" (editorial), The New York Times (June 11, 1997), p. 24.

145. Cameco Corporation, "Discussions Suspended Concerning Russian Highly Enriched Uranium," press release (December 11, 1997).

${ }^{146}$ The Ux Weekly (April 27, 1998), p. 3.
} 
depends on resolving a variety of issues transcending national and international interests. For example, U.S. Government officials have favored the negotiation of a weapons plutonium disposition agreement between the United States and Russia as a precursor to large-scale expenditures for U.S. disposition facilities. ${ }^{147}$ To date, no such agreement exists between the two countries.

The plutonium disposition program would not be implemented until an assessment of the potential environmental impacts has been completed for the proposed siting, construction, and operation of the required facilities. The construction of facilities will be required for converting surplus plutonium materials into plutonium oxide and for fabricating MOX fuel. Because the technology for burning MOX fuel in commercial reactors is well established, most of the uncertainty lies in licensing and public acceptance. Each of the facilities and the commercial reactors where irradiation would take place must be licensed by relevant government agencies. The plutonium disposition program must also gain widespread public acceptance. Environmental interest groups have opposed the reactor option for the disposition of plutonium. For example, the Nuclear Control Institute, the National Resources Defense Council, and Greenpeace petitioned the Nuclear Regulatory Commission in 1996 to reject a proposal by DOE to ship plutonium to Canada. ${ }^{148}$ The shipments were to be made to test the feasibility of burning MOX fuel in CANDU reactors (see page 41).

\section{Supply and Demand Constraints in the Western Market}

\section{Operable Nuclear Power Generating Capacity}

Projections of uranium and enrichment requirements are based on assumptions about nuclear power generation and fuel management practices. One of the most important assumptions, operable capacity, is particularly subject to considerable uncertainty. Electric industry restructuring in the United States and other countries and political opposition, especially in Europe, could result in early plant retirements. In the Far East, Korea and other countries with plans to add nuclear generating capacity have experienced recent economic difficulties. ${ }^{149}$ As a result, new plant construction is likely to be delayed as financing becomes more difficult to secure. Also, public opposition to the construction of new nuclear power plants in Japan could result in the installation of less new capacity than had been anticipated. Any of these situations would result in a decline in demand for uranium and nuclear fuel cycle services.

Examples of early retirements announced in 1997 for nuclear power plants are Maine Yankee in the United States and seven reactor units at the Bruce $A$ and Pickering A plants in Canada. Ontario Hydro could possibly return the Bruce $A$ and Pickering $A$ reactors to service, but only upon Board approval based on economic and market considerations. ${ }^{150}$ The total net generating capacity of the seven units is approximately 4,600 megawatts-electric. ${ }^{151}$ Due to the closures, Ontario Hydro's annual uranium requirements will be reduced by about 1.4 million pounds $\mathrm{U}_{3} \mathrm{O}_{8} .{ }^{152}$

\section{Commercial MOX Fuel Usage}

The use of plutonium in MOX fuel displaces the need for newly produced uranium and enrichment services (see Chapter 2). MOX fuel is projected by the Uranium Institute to displace 4.9 million pounds $\mathrm{U}_{3} \mathrm{O}_{8}$ in 2000 , increasing to 8.0 million pounds $\mathrm{U}_{3} \mathrm{O}_{8}$ in $2010 .{ }^{15.3}$ These projections do not include the possible use of MOX fuel in Russia and the United States. Moreover, recent changes in government policy could limit the growth of MOX fuel usage in existing commercial programs. In October 1997, France's newly elected Socialist government announced that plutonium recycling would not be expanded. ${ }^{154}$ This development is particularly significant because France is the leader in MOX fuel utilization.

\footnotetext{
${ }^{147}$ U.S. General Accounting Office, Nuclear Nonproliferation and Safety: Uncertainties About the Implementation of U.S.-Russian Plutonium Disposition Efforts, Report to the Chairman, Committee on Foreign Relations, U.S. Senate, GAO/RCED-98-16 (Washington, DC, January 1998), p. 2.

${ }^{148}$ The Ux Weekly (October 7, 1996), p. 2.

149 "Economic Crisis Tests Pacific Bloc," The Washington Post (November 23, 1997), p. A24.

${ }^{150}$ Ontario Hydro, "Statement by William Farlinger, Chairman and Interim Chief Executive Officer," press release (Toronto, August 13, 1997).

151 Energy Information Administration, Nuclear Power Generation and Fuel Cycle Report 1997, DOE/EIA-0436(97) (Washington, DC, September 1997), Table D1.

152 The Uranium Institute, News Briefing 97-33-1 (London, August 1997).

153 The Uranium Institute, The Global Nuclear Fuel Market: Supply and Demand 1995-2015 (London, June 1996), Table 8.3.

${ }^{154}$ Nucleonics Week (October 23, 1997), p. 1.
} 


\section{Trade Restrictions and Other National Policies}

Unlike the SWU component, the natural uranium feed component of LEU blended down from Russian HEU (Russian feed) was not marketed prior to 1997. The availability of Russian feed to U.S. end users is restricted to matched sales quotas of the Suspension Agreement with Russia and the direct quotas authorized by the USEC Privatization Act (see Chapter 4). ${ }^{155}$ The pre-1997 Russian feed purchased by Global Nuclear Services and Supply from DOE is expected to enter the market over the next several years through matched sales contracts. Both U.S. producers and utilities have already embraced matched sales of uranium from Russian mines and other commercial sources. Since Russian imports are generally less costly to purchase than U.S.-origin uranium, utilities can reduce their overall fuel costs by matching uranium from both sources. U.S. producers also benefit because it improves the marketability of their product. In 1996, the equivalent of 3.7 million pounds $\mathrm{U}_{3} \mathrm{O}_{8}$ of Russianorigin material were delivered to U.S. utilities as part of 24 matched sales transactions made in 1996 or prior years. $^{156}$ As of December 31, 1996, 14 matched sales contracts remained in effect for future deliveries of Russian-origin uranium.

Based on the purchase of LEU produced from 18 metric tons of HEU, USEC was expected to make available the equivalent of 14.4 million pounds $\mathrm{U}_{3} \mathrm{O}_{8}$ of Russian feed to the Russian Executive Agent in 1997. Assuming that the matched sales quota will be used for the sale of pre1997 Russian feed, all of this uranium would have to be sold outside the United States in 1997 (Figure 8). The direct quota for selling Russian feed to U.S. end users does not take effect until 1998; however, not until 2004 will more than half of the scheduled supply of Russian feed be permitted to be sold to U.S. end users.

The availability of Russian feed also is likely to be limited for end use in the European Union (EU) and Japan. The Euratom Supply Agency (ESA) has enacted a policy designed to ensure a security of supply for its EU member countries through diversification. ${ }^{157}$ To achieve this goal, ESA has sought to limit imports from the Commonwealth of Independent States (CIS), including Russia, to 25 percent of total purchasing contracts. This policy is considered flexible in that it
Figure 8. Potential Availability of Uranium Feed from the Blending Down of Russian Highly Enriched Uranium to Low-Enriched Uranium, 1997-2010

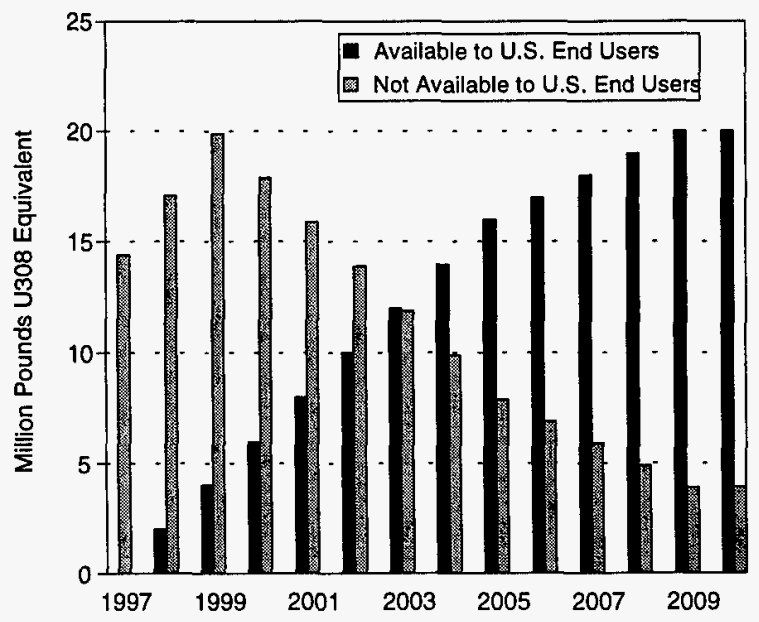

Assumptions: (1) Availability to U.S. end users based on direct quota authorized by the USEC Privatization Act. (2) Annual quantity of uranium feed reflects likely capacity for blending down Russian HEU to LEU. The quantity for 19972001 was determined by an agreement between the United States Enrichment Corporation (USEC) and Techsnabexport, November 1996. (3) For 2002 and later years, it is assumed that 30 metric tons of Russian HEU will be blended down to LEU per year. (4) Does not consider uranium feed contained in the LEU derived from 18 metric tons of Russian HEU that was purchased by USEC in 1995 and 1996.

Source: U.S. quota-USEC Privatization Act (April 26, 1996), Section 3112 (b).

does not apply strict quotas set by law. In addition, ESA has ruled that Russian feed returned by USEC to the Russian Executive Agent for subsequent sale to EU countries would be considered a Russian import. Because CIS imports have exceeded 25 percent of total purchasing contracts in the past several years, ESA is planning to monitor the situation carefully. As a result, the penetration of the EU market by Russian feed could be restricted over the short term. However, increasing quantities of Russian feed are expected to be sold to the EU as existing contract commitments expire in the coming years.

In past years, utilities in Japan generally have not purchased uranium from Russia. Political differences

${ }^{155}$ See Table 3-2 for annual quotas established by the Amendment to the Agreement Suspending the Anti-dumping Investigation on Uranium from the Russian Federation, March 11, 1994 (Suspension Agreement with Russia).

${ }^{156}$ Energy Information Administration, Form EIA-858, "Uranium Industry Annual Survey 1996."

${ }^{157}$ Euratom Supply Agency, Annual Report 1996, p. 10. 
between the countries played an important role in barring Russian uranium imports. In recent months, however, relations between Japan and Russia have begun to improve. The two countries have exchanged visits by top defense officials and discussed arms sales, and trade and Japanese investments in Russia have been accelerated. ${ }^{158}$ This change in the relationship of the two countries suggests that Japan could become a significant consumer of Russian-origin uranium over the next few years. The possibility of Japan purchasing Russian feed could be enhanced should the Russian Executive Agent sell the Russian feed it receives from USEC to suppliers that have established relationships with Japanese utilities.

\section{Unfilled Requirements and Other Procurement Issues}

Assuming that commercialization schedules are met, U.S. and Russian surplus defense inventories must compete in the world uranium market against traditional sources of supply. The extent to which utilities' requirements are covered by existing contract commitments with suppliers will dampen the introduction of new sources of uranium. Because utilities operate on long-range planning horizons, a large share

\section{Figure 9. Anticipated Uranium Market Requirements of U.S. Utilities, 1997-2006, as of December 31, 1996}

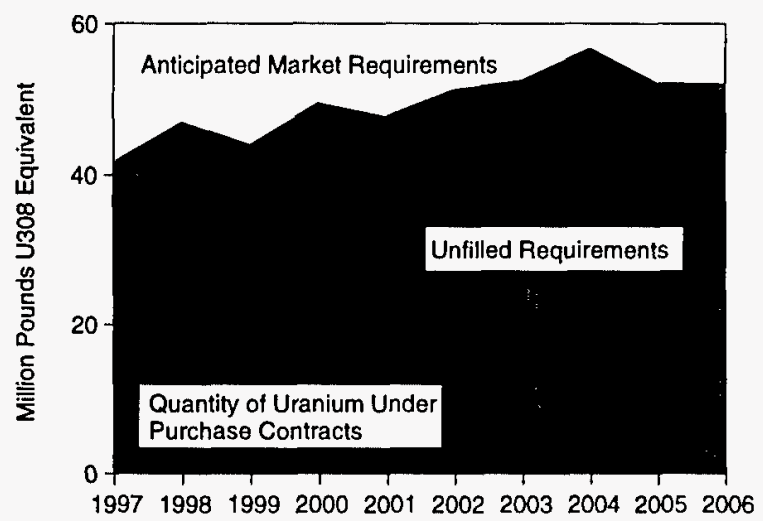

Source: Energy Information Administration, Uranium Industry Annual 1996, DOE/EIA-0478(96) (Washington, DC, April 1997), Table 21. of market transactions have been made for long-term supply commitments well in advance of actual deliveries. For example, U.S. utilities reported in the beginning of 1997 that 82 percent of their anticipated 1998 requirements were covered by purchase contracts concluded prior to the end of $1996 .{ }^{159}$ In future years, progressively smaller shares of requirements are covered by current contract commitments (Figure 9). Those countries with more conservative procurement policies than the United States would be expected to have a greater share of their future requirements covered by existing commitments. Thus, the opportunities for selling competitively priced uranium, including that from surplus defense inventories, through longer-term contracts will increase in later years.

Utilities have traditionally favored procurement from diversified suppliers. By the end of the next decade, the quantity of Russian feed that is permitted by law to be sold to U.S. end users will reach one-half of U.S. reactor requirements (Figure 10). ${ }^{160}$ Because of diversification policies, sales of Russian feed to U.S. utilities might not reach the maximum level permitted by law.

\section{Figure 10. Quota for Deliveries to U.S. End Users of Uranium Feed from the Blending Down of Russian Highly Enriched Uranium to Low-Enriched Uranium as a Share of Projected U.S. Uranium Requirements, 1997-2010}

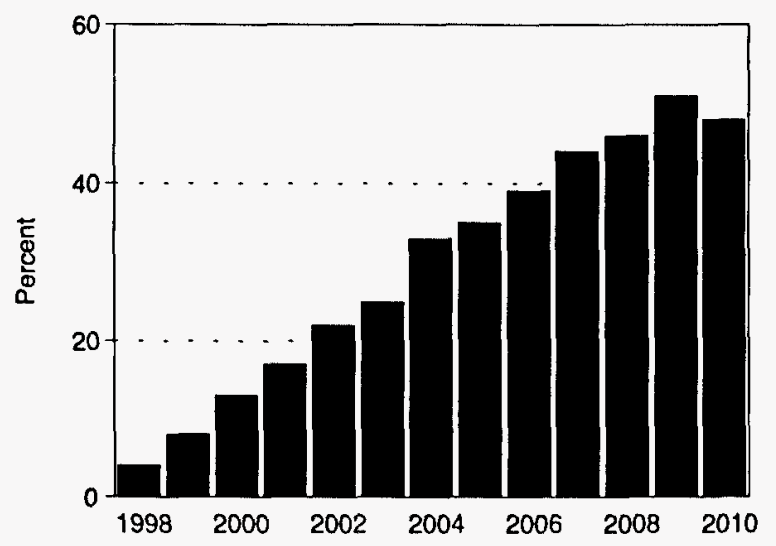

Sources: Projected U.S. uranium requirements-Energy Information Administration, Nuclear Power Generation and Fuel Cycle Report 1997, DOE/EIA-0436(97) (Washington, DC, September 1997), Table F1; U.S. quota-USEC Privatization Act (April 26, 1996), Section 3112 (b).

158 "Tokyo and Moscow Show Warming Relations," The Washington Post (May 31, 1997), p. A14.

${ }^{159}$ Energy Information Administration, Uranium Industry Annual 1996, DOE/EIA-0478(96) (Washington, DC, April 1997 ), Table 21.

${ }^{160}$ Energy Information Administration, Nuclear Power Generation and Fuel Cycle Report 1997, (DOE/EIA-0436(97) (Washington, DC, September 1997), Table F1. 


\section{Nuclear Fuel Market Transactions}

The nuclear fuel market, like any market, consists of transactions between buyers and sellers. Utilities, producers, and market intermediaries engaged in brokering or trading products and services can act as both buyers and sellers. Transactions are contractual obligations to provide goods and services in exchange for money or other considerations. Contractual obligations between buyers and sellers are referred to as "contract commitments." In the nuclear fuel market, contract commitments can be in effect for less than a year or for as long as 10 years or more from the date of contract execution.

Historically, the majority of commitments between utilities and suppliers have been made on a longer-term basis. For example, contracts with deliveries occurring over a period of 3 years or more from the execution date (mediumterm and long-term contracts) were responsible for 75 percent of the uranium delivered to U.S. utilities during 1996. ${ }^{a}$ Long-term commitments have provided utilities with a steady supply of nuclear fuel at costs that fall within utilities' planned procurement budgets. The nuclear industry is interested in the predictability of cash flows that can be realized through long-term commitments. Also, investments in new capacity or in the expansion of existing capacity are seldom made without securing long-term commitments from utilities to purchase products or services.

The remainder of utility purchases have been concluded through shorter-term contracts, especially as purchases in the spot market. ${ }^{b}$ Deliveries from spot-market purchases are completed within a year of contract execution. The spot-market price can experience considerable volatility. In 1996, for example, the spot-market price for the restricted uranium market rose 45 percent from the beginning of the year to June 30 , before declining 65 percent by the end of the year. ${ }^{c, d}$ The volatility of spot-market prices offers market participants the opportunity to secure supply at prices below existing contract prices.

To take advantage of relatively lower spot-market prices, utilities are interested in maintaining a certain degree of flexibility in their procurement practices. Some long-term contracts with suppliers offer utilities an option of receiving additional quantities above a base amount. When the spot-market price is higher than the long-term price, utilities can lock in on the lower long-term price. Conversely, this quantity flexibility places utilities in a position to realize cost savings by filling the remainder of requirements with lower cost spot-market purchases. Uranium producers also have purchased uranium from the spot market and subsequently sold it to utilities at a higher contract price. This practice became increasingly common in the late 1980 s as the spot-market price fell below the marginal production costs of many producers.

${ }^{a}$ Energy Information Administration, Uranium Industry Annual 1996, DOE/EIA-0478(96) (Washington, DC, April 1997), Table 16.

${ }^{b} \mathrm{~A}$ utility can also fill its requirements through loans or exchanges with other utilities or by drawing down excess inventories.

${ }^{\mathrm{C}} \mathrm{A}$ two-tier market was developed at the end of 1992 as a result of the suspension agreements that restrict imports from the republics of the former Soviet Union.

'Exchange value as reported in TradeTech, The Nuclear Review (October 1997).

Nevertheless, Russian feed could gain wide acceptance if it is marketed by a supplier that can offer a proven record of reliability and excess production capacity to cover unanticipated disruptions.

\section{Strategies for Marketing Uranium}

As long as it remains the U.S. Executive Agent over the life of the Russian HEU Agreement, USEC is expected to purchase 92 million SWU contained in the LEU blended down from 500 metric tons of Russian HEU. The uranium feed component of the LEU will be returned by USEC to the Russian Executive Agent for subsequent commercial sale. For 4 years, Western suppliers negotiated with MINATOM to purchase Russian feed. In August 1997, an agreement in principle was reached whereby Cameco Corp. and Cogema, two of the world's largest uranium producers, could each purchase 45 percent of the Russian feed made available by the Russian Executive Agent. Nukem Inc., a uranium trading company, would receive 10 percent. However, as described in Chapter 4, negotiations between the parties were suspended in December 1997. Russia is expected to market the uranium to Western consumers through its representatives, Global Nuclear Supply and Services (GNSS) and Techsnabexport (TENEX). 
The three Western producers, USEC, Cameco, and Cogema, were expected to sell most if not all of their acquired uranium through longer term contracts. USEC is also expected to sell SWU in a similar fashion. Producers would also have the flexibility to modify production plans to accommodate these acquisitions by closing down more costly capacity or delaying the start of new projects. These strategies are likely to ensure more stable prices, which would support the costs of producing uranium or providing enrichment services.

Nukem, on the other hand, could sell a much greater share of uranium on the spot market than the producers group. Without its own production capacity, Nukem could implement a marketing strategy directed toward gaining market share at the expense of producers and decreasing its inventory holding costs, in part by offering uranium at competitive prices on the spot market. Selling on the spot market, however, has become increasingly unattractive with recent price declines. The average uranium spot-market price has declined from $\$ 16.50$ per pound $\mathrm{U}_{3} \mathrm{O}_{8}$ in June 1996 to below $\$ 11.00$ per pound $\mathrm{U}_{3} \mathrm{O}_{8}$ in June $1997 .{ }^{161}$ More likely, a firm engaged in trading would conclude a significant number of long-term contracts to establish itself as a reliable supplier.

Russia is also expected to favor longer term contracts. The HEU feed provides GNSS and TENEX with an alternative source of supply to meet existing contracts and pursue new contracts. Historically, Russia has exported uranium from inventories and mine production. Russia has indicated that it would sell the uranium feed at a floor price above the average of world market prices. ${ }^{162}$

Under current plans to transfer HEU and natural uranium, USEC could receive the equivalent of up to 37.5 million pounds $\mathrm{U}_{3} \mathrm{O}_{8}$ and 5.7 million SWU in $\mathrm{HEU}$ and natural uranium transferred from DOE. The ownership of natural uranium could allow USEC to become a major producer of enriched uranium product.

\section{Excess Commercial Inventories}

Since the early 1980s, excess inventories held by suppliers and utilities have filled a gap between uranium production and demand in the West. Imports from the Commonwealth of Independent States (CIS), especially from Kazakhstan, Russia, and Uzbekistan, have contributed to this supply. For example, Euratom reported that the equivalent of 43.2 million pounds $\mathrm{U}_{3} \mathrm{O}_{8}$ was imported to the EU from the CIS in $1996 .{ }^{163}$ Of this amount, 17.7 million pounds $\mathrm{U}_{3} \mathrm{O}_{8}$ was under purchase contracts for EU utilities. The remaining quantity of uranium was held in inventory for later delivery to customers both in and outside the EU. In comparison, Kazakhstan, Russia, and Uzbekistan produced only 12.5 million pounds $\mathrm{U}_{3} \mathrm{O}_{8}$ from mines during 1996 (Figure 11). ${ }^{164}$ From these data, it is evident that the CIS had been exporting uranium from inventories.

In the United States, inventories held by utilities and suppliers, excluding DOE and USEC, increased from the equivalent of 72.5 million pounds $\mathrm{U}_{3} \mathrm{O}_{8}$ at the end of 1995 to 81.2 million pounds $\mathrm{U}_{3} \mathrm{O}_{8}$ at the end of 1996, a gain of 12 percent. ${ }^{165}$ This increase, the first for the United States since the early 1980s, is attributed to discretionary purchases made by utilities during 1995 and 1996.

Because of the uncertainty regarding the availability of CIS imports, it is difficult to assess the level of excess inventories in the future. Commercial inventories are likely to continue to be an important supply over the next several years. By 2000, CIS imports are expected to decrease to levels matching production. With less available CIS supply, commercial inventories could be drawn down to levels no longer considered as excessive. At the same time, U.S. and Russian surplus defense inventories are expected to fill the role held by traditional commercial inventories in supplying the deficit between uranium demand and production.

\section{Availability of Russian Feed for Western Consumption}

Assuming that HEU blending meets the schedule pursuant to the Russian HEU Agreement, not all of the uranium feed component (Russian feed) is likely to be made available for Western consumption. To earn foreign exchange, Russia is expected to sell much of the Russian feed to the West. Nevertheless, Russia has

\footnotetext{
${ }^{161}$ Spot-market price is the monthly Exchange Value for the restricted U.S. market, as reported in TradeTech, The NUCLEAR Review (August 1997).

${ }_{162}$ Cameco Corporation, "Discussions Suspended Concerning Russian Highly Enriched Uranium," press release (December 11, 1997).

${ }^{163}$ Euratom Supply Agency, Annual Report 1996, p. 10.

${ }^{164}$ The Uranium Institute, "World Uranium Production and Nuclear Share," fact sheet (October 16, 1997).

${ }^{165}$ Energy Information Administration, Uranium Industry Annual 1996, DOE/EIA-0478(96) (Washington, DC, April 1997), Table 31.
} 

Figure 11. Historical and Potential Annual Supply
Comparisons

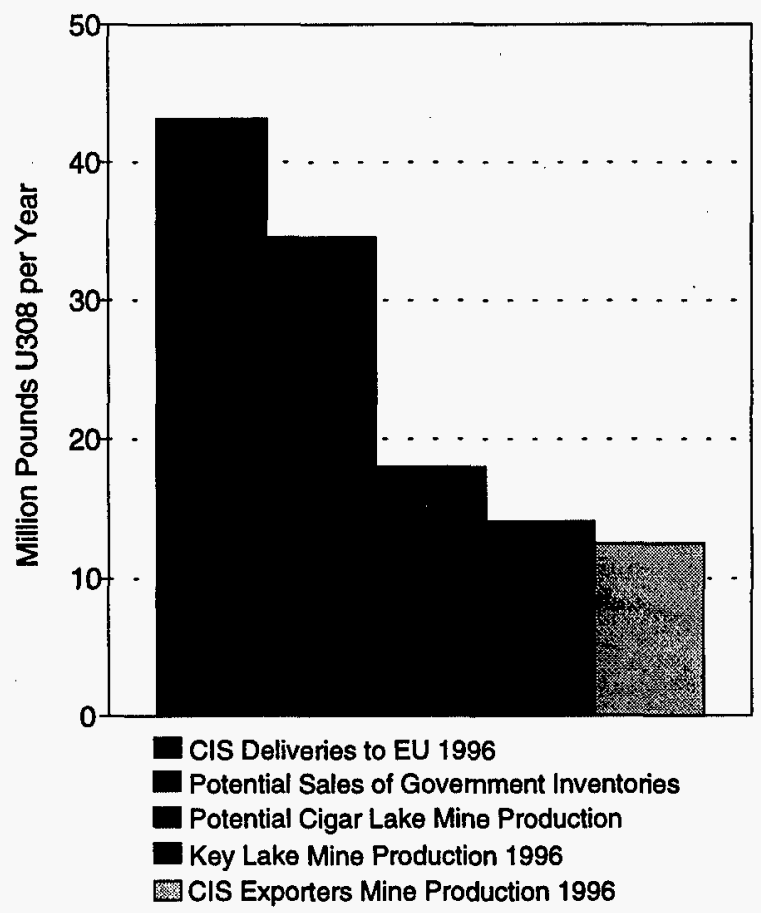

Explanation: CIS-Commonwealth of Independent States; EU-European Union; Government inventories-U.S. and Russian surplus defense inventories; CIS exporters-Kazakhstan, Russia, and Uzbekistan.

Assumptions: (1) uranium feed component of LEU derived from Russian HEU is delivered to end users in the same year that it becomes available and (2) maximum legal quantities of uranium derived from U.S. surplus defense inventories of $\mathrm{HEU}$ and natural uranium are sold.

Sources: CIS deliveries to EU-Euratom Supply Agency, Annual Report 1996 (1997), p. 10; Government inventories-this report; Potential Cigar Lake mine production-Cigar Lake Mining Corporation, The Cigar Lake Projected Environmental Impact Statement (Executive Summary) (July 1995) p. 7; Key Lake mine production-Natural Resources Canada, "Canadian Uranium Statistics Fact Sheet" (July 1997); CIS exporters mine production-International Atomic Energy Agency, "World Uranium Production and Nuclear Share," fact sheet (October 16, 1997).

indicated that it could reserve some material for internal uses. ${ }^{166}$ Potential internal uses would be for filling: (1) Russian reactor requirements, (2) longstanding commit- ments by Russia to provide fuel for reactors in neighboring countries, and (3) requirements for blendstock in converting HEU to LEU. A reduction in the availability of Russian feed could have important market ramifications. For example, if Russia would reserve for internal use 25 percent of the Russian feed to be returned by USEC in 1999, the equivalent of 6 million pounds $\mathrm{U}_{3} \mathrm{O}_{8}$ would have to be supplied from other sources. In comparison, the United States produced 6.3 million pounds $\mathrm{U}_{3} \mathrm{O}_{8}$ in $1996 .{ }^{167}$

\section{Analysis of Potential Russian Needs}

The timing and extent by which Russia uses HEU feed for internal purposes are expected to be influenced by the adequacy of current supplies in meeting future requirements. Besides its own reactor requirements, Russia has long-term fuel export commitments to neighboring countries such as Armenia, Bulgaria, Lithuania, and Ukraine. Russia and these four neighboring countries are projected to require 262 million pounds $\mathrm{U}_{3} \mathrm{O}_{8}$ to operate reactors between 1997 and $2010 .{ }^{168}$ No official information is available about the size of commercial inventories and other Russian internal supplies.

With Russian uranium production generally reserved for exports, internal reactor requirements have been filled by drawing down inventories of natural uranium and LEU and by enriching depleted uranium contained in enrichment tails. ${ }^{169}$ Inventories of natural uranium and LEU are considered to be "commercial" because the contained uranium has been used for both internal reactor requirements and exports to the West. Analysis published in 1995 concluded that Russian commercial inventories may be on the order of 195 million pounds $\mathrm{U}_{3} \mathrm{O}_{8}$ equivalent. ${ }^{170}$

To meet requirements related to the Russian HEU Agreement, additional utilization of enrichment tails is likely to be reserved for the blending of HEU to LEU. Thus, the drawdown of commercial inventories could account for over 75 percent of the uranium supplied to meet internal reactor requirements. ${ }^{171}$ The following analysis considers the drawdown of Russian commercial inventories as the key factor for establishing the

${ }^{166}$ Cameco Corporation, "Cameco Signs Uranium Agreement in Principle with Russia," press release (August 18, 1997).

${ }^{167}$ Energy Information Administration, Uranium Industry Annual 1996, DOE/EIA-0478(96) (Washington, DC, April 1997 ), Table 5.

${ }^{168}$ Energy Information Administration, International Nuclear Model, Reference Case 1997.

${ }^{169}$ O. Bukharin, "Analysis of the Size and Quality of Uranium Inventories in Russia," paper presented at the Nuclear Energy Institute's International Uranium Fuel Seminar (Williamsburg, VA, October 1995).

${ }^{170}$ Ibid.

${ }^{171}$ Based on reactor requirements of 18 million pounds $\mathrm{U}_{3} \mathrm{O}_{8}$ equivalent and 4 million pounds $\mathrm{U}_{3} \mathrm{O}_{8}$ equivalent supplied from reenriching depleted uranium from enrichment tails. 
likelihood that Russian feed will be used for internal purposes.

Two scenarios, reference and mine closure, were developed to assess the potential impacts of different supply assumptions on the drawdown of estimated Russian commercial inventories through 2010. For both scenarios, the reactor requirements of Russia, Armenia, Bulgaria, Lithuania, and Ukraine were assumed to be filled by uranium production from Russia and Ukraine, re-enrichment of depleted uranium from Russian enrichment tails, and the drawdown of Russian commercial inventories. All mine production and inventory drawdown, were assumed to be used to meet internal needs. Russian feed was assumed to be made available for export to the West. The annual supply of uranium from enrichment tails was assumed to remain constant.

For the reference scenario, uranium mine production was assumed to continue annually at 1996 rates through 2010 (Figure 12). All uranium concentrate from Ukraine would continue to be sent to Russian nuclear fuel cycle facilities to produce fuel for Ukrainian reactors. ${ }^{172}$ With projected requirements in excess of 5 million pounds $\mathrm{U}_{3} \mathrm{O}_{8}$ per year, Ukraine also was assumed to be supplied with uranium from Russia. ${ }^{173}$

In the mine closure scenario, uranium mine production was assumed to be phased out gradually through 2003 (Figure 13). This scenario could be realized if Russia and Ukraine opt to close costly state-owned mining enterprises. Current mines were assumed to become increasingly expensive to operate as higher grade or more accessible ores are depleted. With the annual supply from enrichment tails assumed constant, an increase in inventory drawdown would be necessary to replace mine output.

Assuming no other changes to supply, the mine closure scenario indicates a cumulative commercial inventory drawdown of 171 million pounds $\mathrm{U}_{3} \mathrm{O}_{8}$ equivalent between 1997 and 2010 (Figure 14). To reflect additional drawdown that would have taken place since Bukharin's analysis was published in 1995, Russian commercial inventories at the beginning of 1997 were considered to be somewhat lower than 195 million pounds $\mathrm{U}_{3} \mathrm{O}_{8}$ equivalent. Based on the level of exports described earlier in this chapter, the drawdown of Russian commercial inventories during 1996 may have been

\section{Figure 12. Potential Sources of Supply to Fill Russian Requirements-Reference Scenarlo, 1997-2010}

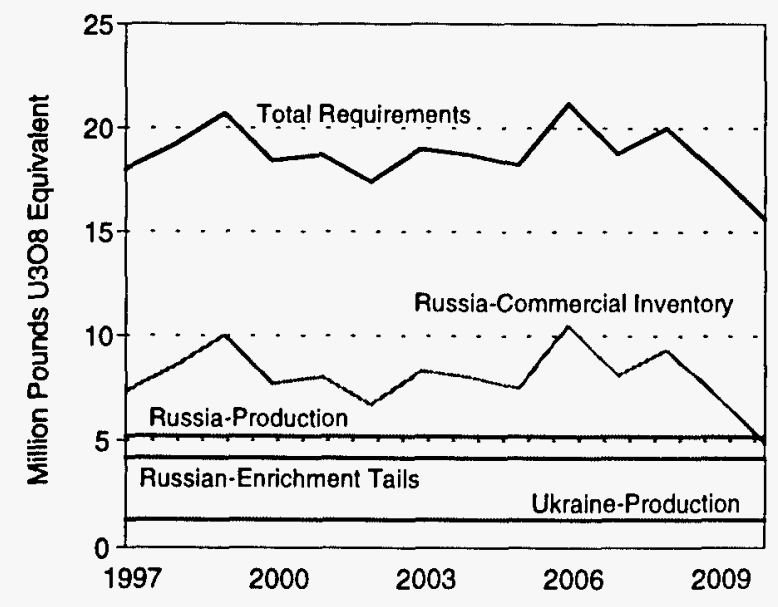

Assumptions: (1) Reactor requirements are for Russia, and to meet long-term commitments to supply fuel for nuclear power plants in Armenia, Bulgaria, Lithuania, and Ukraine (other export contracts are not included). (2) Uranium production remains at 1996 levels. (3) The drawdown of commercial inventory equals requirements less production and enrichment tails.

Sources: 1996 uranium production-Uranium Institute, "World Uranium Production and Nuclear Share," fact sheet (London, October 1997); Russian enrichment tails-O. Bukharin, "Integration of the Military and Civilian Nuclear Fuel Cycles in Russia," Science \& Global Security, Vol. 4 (1994); Requirements-Energy Information Administration, International Nuclear Model (PC Version), File INM.WK4, Reference Case 1997.

greater than in previous years. Thus, the conditions indicated for the mine closure scenario could result in Russian commercial inventories becoming depleted by 2010. In comparison, the drawdown in the reference case is just over 100 million pounds. The two scenarios indicate that between 50 and 100 percent of Russian commercial inventories could be drawn down by late in the next decade. This potential development suggests that Russia would likely require some Russian feed to meet internal fuel supply requirements.

\section{Restrictions on Deliveries to Russia}

Assuming an internal need, Russia must be able to import the Russian feed. To allow Russia to directly take back HEU feed, the United States is required by the Atomic Energy Act of 1954, as amended, to enter into an

\footnotetext{
${ }^{172}$ Organization for Economic Cooperation and Development, Nuclear Energy Agency, and International Atomic Energy Agency, Uranium Resources, Production, and Demand 1995 (Red Book) (Paris, 1996), p. 304.

${ }^{173}$ Energy Information Administration, International Nuclear Model, Reference Case 1997.
} 


\section{Figure 13. Potential Sources of Supply to Fill Russian Requirements-Mine Closure Scenario, 1997-2010}

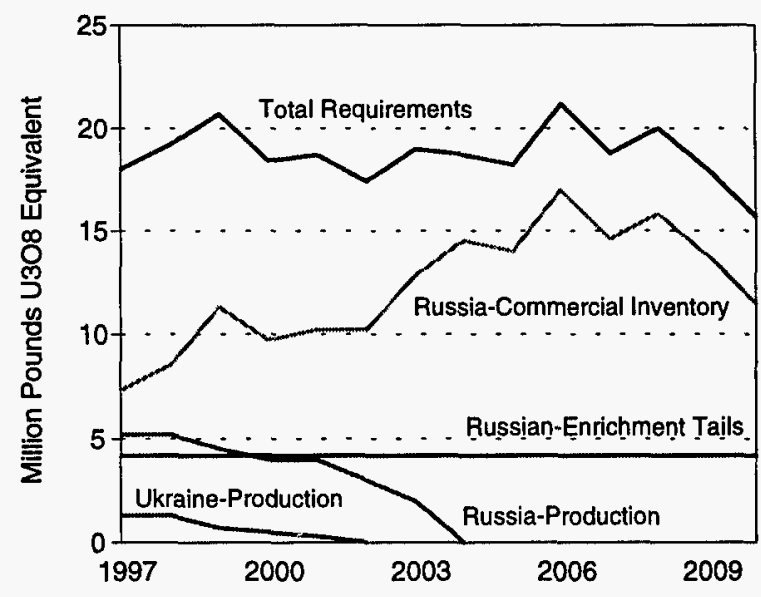

Assumption: Uranium production assumed to gradually decline before ending in 2003.

Sources: Initial level of uranium production-Uranium Institute, "World Uranium Production and Nuclear Share," fact sheet (London, October 1997), p. 79; Russian enrichment tails-O. Bukharin, "Integration of the Military and Civilian Nuclear Fuel Cycles in Russia," Science \& Global Security, Vol. 4 (1994); Requirements-Energy Information Administration, International Nuclear Model (PC Version), File INM.WK4, Reference Case 1997.

agreement of peaceful nuclear cooperation with Russia. The U.S. and Russian governments have not as yet entered into such an agreement. However, the USEC Privatization Act permits USEC to deliver Russian feed to a North American facility designated by the Russian Executive Agent. Once delivered to Canada, the Russian Executive Agent could contract a Canadian

\section{Figure 14. Potential Cumulative Drawdown of Russian Commercial Inventories, 1997-2010}

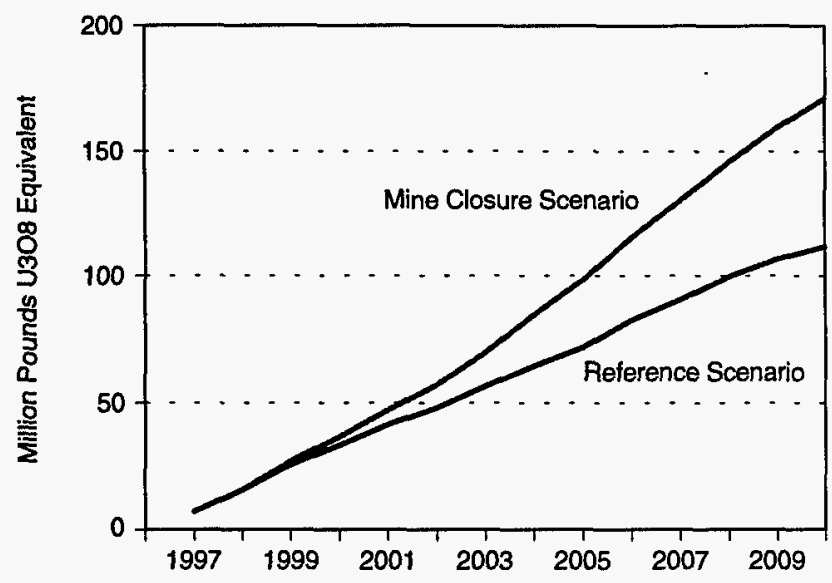

Assumptions: Reference Scenario-uranium production remains at 1996 levels; Mine Closure Scenario-uranium production gradually declines before ending in 2003; all scenarios-the drawdown of Russian commercial inventories equals requirements less production and enrichment tails.

Sources: Initial level of uranium production-Uranium Institute, "World Uranium Production and Nuclear Share," fact sheet (London, October 1997), p. 79; Russian enrichment tails-O. Bukharin, "Integration of the Military and Civilian Nuclear Fuel Cycles in Russia," Science \& Global Security, Vol. 4 (1994); Requirements-Energy Information Administration, International Nuclear Model (PC Version), File INM.WK4, Reference Case 1997.

producer to swap an equivalent amount of uranium mined in Canada for export to Russia. This would be possible because an agreement for peaceful nuclear cooperation exists between Canada and Russia. 


\section{The Effects of Selling Government Surplus Defense Inventories}

The penetration into the marketplace of low-enriched uranium (LEU) derived from the blending down of U.S. and Russian highly enriched uranium (HEU) would displace demand for newly produced uranium $\left(\mathrm{U}_{3} \mathrm{O}_{8}\right)$ and for the conversion and enrichment services that would be required to produce an equivalent amount of LEU. The commercialization of U.S. inventories of natural $\mathrm{UF}_{6}$ would have a displacement effect on the $\mathrm{U}_{3} \mathrm{O}_{8}$ and conversion markets. Based on the market penetration factors described in Chapter 6, this chapter provides an analysis of the potential effects of such displacements on the supply and price of fuel for commercial nuclear power plants. For this analysis, EIA has used economic modeling to provide a detailed assessment of the $\mathrm{U}_{3} \mathrm{O}_{8}$ market. Because enrichment services make up the largest component of fuel procurement costs, a discussion of the likely effects on the markets for enrichment services and enriched uranium is also included. ${ }^{174}$ The availability of U.S. and Russian surplus defense inventories is expected to provide a competitively priced alternative to traditional sources of uranium.

\section{Effects on the Uranium $\left(\mathrm{U}_{3} \mathrm{O}_{8}\right)$ Market}

\section{Uranium Market Analysis Cases}

The sale of U.S. and Russian surplus defense inventories in the commercial market would displace newly produced uranium or uranium supplied from commercial inventories. To analyze the effects of these potential sales, projections of uranium price and supply have been generated from EIA's Uranium Market Model (UMM). The UMM is a microeconomic model in which uranium from available sources of supply is used to meet the demand for uranium by electric utilities' nuclear power plants (Appendix D). The modeling parameters reflect current information on extraction and enrichment technology, uranium reserves, costs, procurement practices, and laws and regulations.

The analysis presented here is restricted to the surplus inventories approved for commercialization as of March 31, 1997 (Table 9). ${ }^{175}$ For the U.S. Government programs, approval includes the completion of environmental impact statements pursuant to the National Environmental Policy Act of 1969 (Chapter 5). Based on the Government approval criterion, the analysis is limited to three inventory classes with specific commercialization schedules: (1) Russian HEU, (2) U.S. HEU, and (3) U.S. commercial-grade inventories of natural uranium and LEU. The time horizon for the market analysis extends to 2010. Other quantities of surplus defense inventories, notably U.S. HEU and U.S. and Russian plutonium, could be made available for commercial use by the end of the next decade, but they are not included in the analysis.

In the case of the agreement between DOE and TVA to use off-specification HEU in TVA reactors (see Chapter 5 ), the LEU derived from the HEU would not be sold on the commercial market but, instead, would displace the equivalent uranium and enrichment services that TVA would have had to purchase in the commercial market. Because the ultimate goal of the utilization program is to provide fuel for nuclear power plants, the LEU derived from U.S. off-specification HEU is considered to penetrate the market in the year that it is delivered to TVA. Since the analysis was completed, DOE has revised the quantity and timing for the commercialization of offspecification HEU reported in Table 9 (see Tables 5 and 6 for the revised plan). These changes are anticipated to have only a marginal impact on the projections of supply and spot-market price presented in this report.

For the 63 metric tons of U.S. HEU to be transferred from DOE to USEC, the uranium contained in the

\footnotetext{
${ }^{174}$ For a typical light-water reactor, enrichment makes up 40 to 50 percent of the cost of fuel reloaded into the reactor core.

${ }^{175}$ By the end of 1997, the Department of Energy offered less uranium for sale than it proposed in the Secretary's Determination of March 1997.
} 
Table 9. Potential Commercial Availability of U.S. and Russian Surplus Defense Inventories, 1997-2010, Based on Schedules Contained in Government Disposition Plans as of March 31, 1997

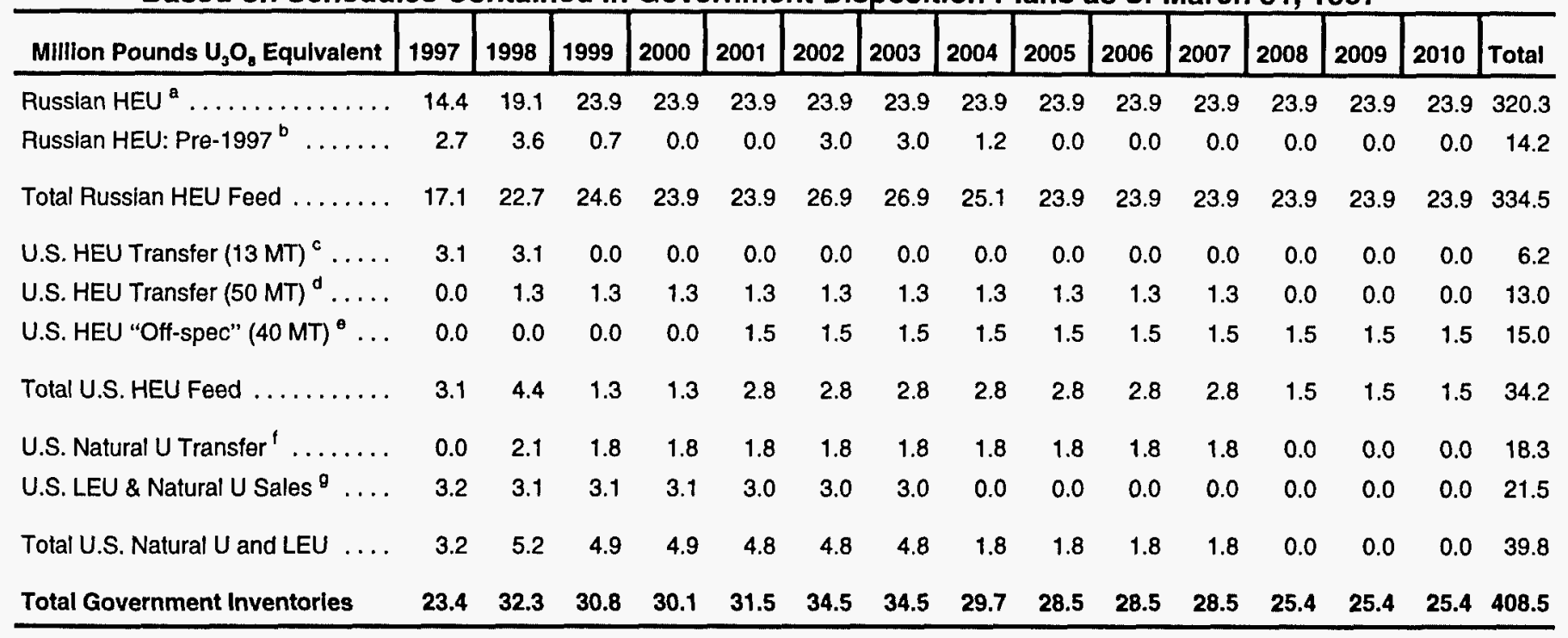

Assumptions: a. As of June 30,1997, the Russian Executive Agent had not sold any of the uranium feed component returned to it by USEC. If sales had begun later in 1997, approximately 50 percent of the uranium feed contained in LEU derived from blending down 18 metrlc tons of HEU (Russian feed) would have been sold in the market during 1997. In subsequent years, it is assumed that 100 percent of Russian feed retumed to the Russian Executive Agent will be sold in the market. The quantity of Russian feed corresponds to the schedule for blending down HEU from 1998 through 2001 established by the amendment to the Russian HEU Agreement, signed in November 1996. For 2002 and later years, it is assumed that 30 metric tons of $\mathrm{HEU}$ will be blended down each year. The uranium content is equivalent to the feed contained in LEU assaying at 4.4 percent ${ }^{235} \mathrm{U}$. The LEU is to be derived from HEU and blendstock, with ${ }^{235} \mathrm{U}$ assays of 90 percent and 1.5 percent, respectively

b. Russian feed derived from LEU purchased by USEC in 1995 and 1996. The sale of this uranium is regulated by the USEC Privatization Act. All ElA cases include the assumption that 7.0 million pounds of $\mathrm{U}_{3} \mathrm{O}_{3}$ will be sold through matched sales contracts, the annual quantity limited by quotas provided for by the Suspension Agreement between the United States and Russia. The remaining 7.2 million pounds $\mathrm{U}_{3} \mathrm{O}_{3}$ will be sold by $\mathrm{DOE}$ beginning in 2002 .

c. USEC plans to add this HEU to its production stream during 1997-1999. Uranium feed is assumed to be made avallable to the market in the year that the corresponding quantity of HEU is blended down into LEU assaying at 4.95 percent ${ }^{235} U$. The LEU is to be derived from HEU and LEU blendstock, with ${ }^{235} \mathrm{U}$ assays of 75.7 percent and 2.0 percent, respectively. However, only the uranlum contalned in the HEU is considered for this analysis, because the blendstock would have been sold in the market regardless of the decision to blend down HEU.

d. Schedule pursuant to USEC Privatization Act. HEU is to be blended down to LEU assaying at 4.95 percent ${ }^{235} U$. The LEU is to be derived from $\mathrm{HEU}$ and natural $U$ blendstock, with average ${ }^{235} \mathrm{U}$ assays of 41.3 percent and 0.71 percent, respectively. However, only the uranium contained in the HEU is considered for this analysis, because the blendstock would have been sold in the market regardless of the decision to blend down HEU.

e. Schedule pursuant to DOE's HEU disposition plan, September 1996. HEU is to be blended down to LEU assaying at 4.60 percent ${ }^{235} \mathrm{U}$. The LEU is to be derived from HEU with an average assay of 66.0 percent ${ }^{235} \mathrm{U}$ and depleted uranlum blendstock with an average assay of 0.30 percent ${ }^{235} \mathrm{U}$. However, only the uranium contained in the HEU is considered for this analysis, because depleted uranium blendstock is currently stored as waste.

f. Schedule pursuant to USEC Privatization Act.

g. DOE is assumed to sell the quantity proposed in the Secretary's Determination, March 1997.

$M T=$ Metric tons.

Sources: Uranium contained in Russian HEU feed and transfer of natural uranium-Energy Resources International, Inc., 1997 Nuclear Fuel Cycle Supply and Price Report (Washington, DC, May 1997); uranium contained in U.S. HEU feed-Russell Schmidt, personal correspondence (HEU Disposition Program Office, Oak Ridge. TN, September 24, 1997); uranium contained in proposed sales of LEU and natural uranium by DOE-U.S. Department of Energy, Office of Nuclear Energy, Science and Technology, Environmental Assessment DOE Sale of Surplus Natural and Low Enriched Uranlum, DOE/EA-1172 (Washington, DC, October 1996).

blendstock has been accounted for in other inventories considered in this analysis. Natural uranium and slightly enriched uranium ( 2.0 percent ${ }^{235} \mathrm{U}$ ) are anticipated to be used for blending down 63 metric tons of U.S. HEU that had been designated for transfer to USEC. To provide a blendstock, USEC could acquire uranium from any of three sources of supply: (1) internal stockpiles held since USEC was created from DOE, (2) transfer by DOE of 7,000 metric tons of natural $\mathrm{UF}_{6}$, or (3) purchases from the commercial market. Whether or not used as blendstock, these sources of supply would likely be sold in the market. 
The penetration of U.S. and Russian surplus defense inventories into the uranium market is anticipated to be constrained over the next few years by the factors discussed in Chapter 6. To reflect the range of potential effects that those constraints could have on the market penetration of surplus inventories, and because market projections in general are subject to considerable uncertainty, three analysis cases were developed. Uranium supplied from surplus defense inventories is modeled in the Uranium Market Model as the first step of the uranium supply curve. It displaces an equivalent quantity of higher cost uranium from one or more known production centers that would have entered the market in the absence of supply from surplus defense inventories. ${ }^{176}$ The three cases assume the same levels of demand for uranium fuel, based on projected requirements of the world's reactors, as described below. Variations in market penetration are provided by different assumptions about the availability of uranium contained in Russian feed and, thus, the total amount of uranium available from surplus defense inventories. The amounts assumed to be available from U.S. Government inventories are the same in all three analysis cases.

In the Reference Case, the quantity of uranium assumed to be sold annually in the market approximates the scheduled availability by 2005 (Figure 15). Sales of uranium contained in Russian feed-the largest component of surplus defense inventories-are assumed to reach the equivalent of 24 million pounds $\mathrm{U}_{3} \mathrm{O}_{8}$ in 2001 and remain at that level through 2010 (Table 10). (This amount is equivalent to the uranium feed contained in LEU blended down from 30 metric tons of HEU). Cumulative sales of Russian feed through 2010 are assumed to be equivalent to 298 million pounds $\mathrm{U}_{3} \mathrm{O}_{8}$.

In the Lower HEU Feed Case (Figure 16 and Table 11), Russian feed equivalent to 8 million pounds $\mathrm{U}_{3} \mathrm{O}_{8}$ per year is assumed to be withdrawn from the Western market for internal Russian use beginning in 2002. (This amount is equivalent to one-third of the uranium feed contained in LEU blended down from 30 metric tons of HEU.) Because not all the available Russian feed is sold during the period 1997-2000, the supply from stockpiles is assumed to maintain the availability of Russian feed at 24 million pounds $\mathrm{U}_{3} \mathrm{O}_{8}$ per year from 2002 through 2005. By 2007, the availability of Russian feed is reduced
Figure 15. Comparison of Planned Commercial Availability of Uranium Derived from U.S. and Russian Surplus Defense Inventories and Market Penetration Assumed for EIA Reference Case, 1997-2010

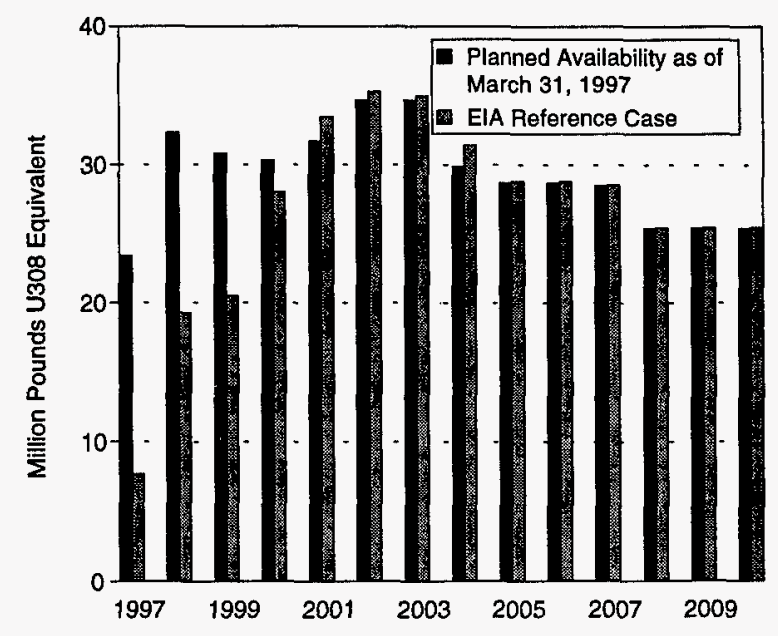

Sources: Uranium contained in Russian HEU feed and transfer of natural uranium-Energy Resources International, Inc., 1997 Nuclear Fuel Cycle Supply and Price Report (Washington, DC, May 1997); uranium contained in U.S. HEU feed-R. Schmidt, personal correspondence (HEU Disposition Program Office, Oak Ridge, TN, September 24, 1997); uranium contained in proposed sales of LEU and natural uranium by DOE-U.S. Department of Energy, Office of Nuclear Energy, Science and Technology, Environmental Assessment DOE Sale of Surplus Natural and Low Enriched Uranium, DOE/EA-1172 (Washington, DC, October 1996).

to 16 million pounds $\mathrm{U}_{3} \mathrm{O}_{8}$ per year. Through 2010, cumulative sales of Russian feed are assumed to be equivalent to 262 million pounds $\mathrm{U}_{3} \mathrm{O}_{8}$.

In the Upper HEU Feed Case (Figure 16 and Table 12), Russian feed that was not sold during 1997-2000 is assumed to enter the uranium market in increments of 2.0 million pounds $\mathrm{U}_{3} \mathrm{O}_{8}$ per year in 2002 , increasing to 4.0 million pounds $\mathrm{U}_{3} \mathrm{O}_{8}$ per year in 2003 through 2010 . The total amount of Russian feed (not including pre-1997 feed) assumed to be sold to meet demand peaks at 28.0 million pounds $\mathrm{U}_{3} \mathrm{O}_{8}$ per year in 2003 and subsequent years. Cumulative sales of Russian feed through 2010 are assumed to be equivalent to 332 million pounds $\mathrm{U}_{3} \mathrm{O}_{8}$.

\footnotetext{
${ }^{176}$ The equation used in the Energy Information Administration's Uranium Market Model for projecting the uranium spot-market price is as follows: spot-market price at the forecasted time equals a weighted average consisting of the spot-market price for the previous time ( 30 percent) and the "equilibrium spot-market price" for the forecasted time ( 70 percent). The equilibrium spot-market price is established at $\$ 0.01$ less than the minimum acceptable selling price, or reported marginal cost, of the lowest cost production center whose production did not make it into the market.
} 
Table 10. Assumed Market Penetration of U.S. and Russian Surplus Defense Inventorles in the Uranlum Market, 1997-2010, Reference Case

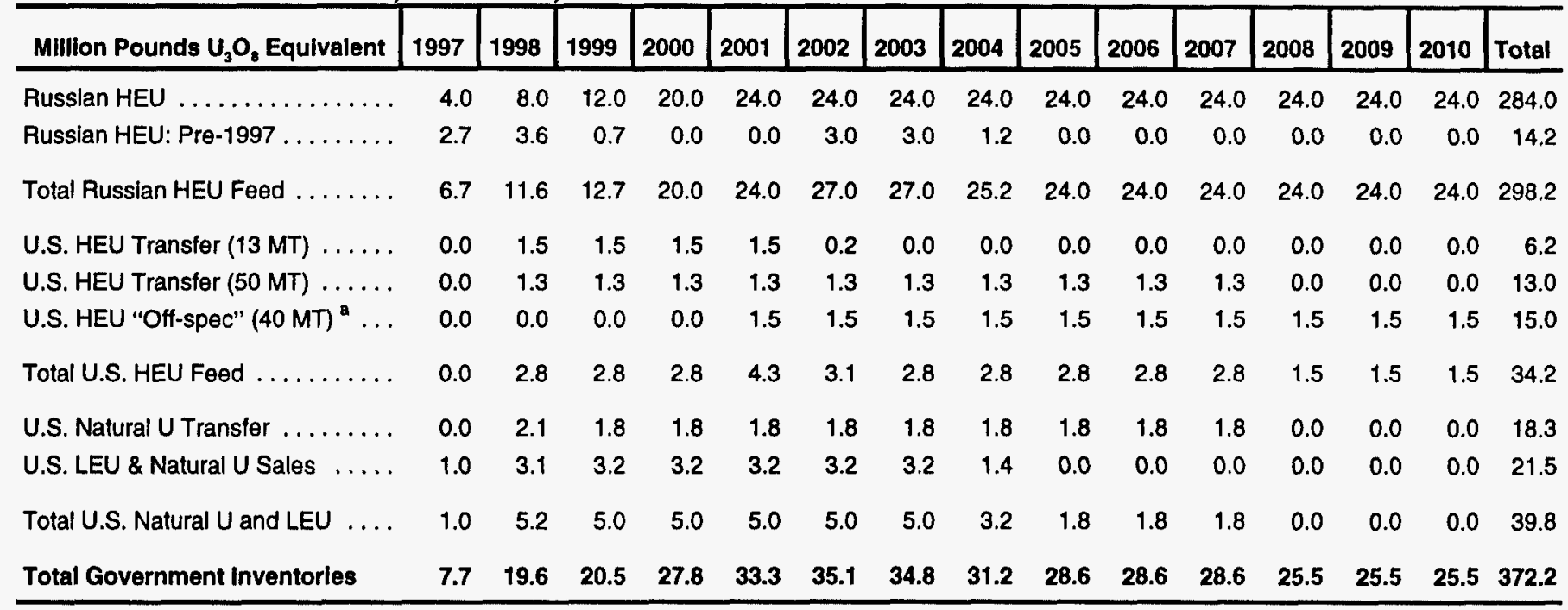

Assumptions: For the Reference Case, EIA assumes that the sales of uranium derived from U.S. and Russian govemment surplus inventories will be delayed due to programmatic and market conditions. See Table 7-1 for assumptions used in determining the equivalent amount of uranium contained in the inventories.

"Since the analysis was completed, the U.S. Department of Energy has revised the quantity and timing for the commerclalization of "off-spec" HEU. These changes are anticipated to have only a marginal impact on projections of supply and spot-market price.

MT = Metric tons.

Sources: Uranium contalned in LEU blended down from Russian HEU and transfer of natural uranium-Energy Resources International, Inc., 1997 Nuclear Fuel Cycle Supply and Price Report(Washington, DC, May 1997); uranlum contained in U.S. HEU feed-R. Schmidt, personal correspondence (HEU Disposition Program Office, Oak Ridge, TN, September 24, 1997); uranium contained in proposed sales of LEU and natural uranlum by DOE-U.S. Department of Energy, Office of Nuclear Energy, Science and Technology, Environmental Assessment DOE Sale of Surplus Natural and Low Enriched Uranium, DOE/EA-1172 (Washington, DC, October 1996).

For demand, the UMM uses projections of uranium required by the world's reactors generated by EIA's International Nuclear Model PC Version (PCINM) for the 1997 Reference Case published in the Nuclear Power Generation and Fuel Cycle Report 1997. ${ }^{177}$ The PCINM Reference Case assumes that most reactors will operate to the end of their license limits. For the United Sates, only 8 of the 110 reactors operable as of December 31 , 1996, are considered as candidates for early shutdown. Over the UMM forecast period of 1997 through 2010, the world's reactor requirements are projected to vary from 158 million pounds $\mathrm{U}_{3} \mathrm{O}_{8}$ to 167 million pounds $\mathrm{U}_{3} \mathrm{O}_{8}$ per year, ${ }^{178}$ reaching their highest level during the middle of the next decade and declining slightly by 2010 (Table 13). For this analysis, the projections of Western world reactor requirements were modified to include the displacement of uranium arising from the use of MOX fuel in Western Europe and Japan as projected by the
Uranium Institute (Table 13). ${ }^{179}$ The three analysis cases do not consider the possible use of MOX fuel in Russia and the United States.

\section{Uranium Price and Supply Outlook}

Because the uranium reactor requirements for nuclear reactors in China and CIS are supplied internally, the following discussion of uranium price and supply focuses on the Western market. For this analysis, uranium price refers to the spot-market price for the U.S. market, in which CIS imports are restricted. With increasingly larger quantities of Russian-origin uranium to be supplied from HEU, the distinction between the restricted and unrestricted prices is expected to diminish, possibly disappearing altogether. The following projections of price and supply represent broad trends that do not reflect short-term market volatility.

\footnotetext{
${ }^{177}$ Energy Information Administration, Nuclear Power Generation and Fuel Cycle Report 1997, DOE/EIA-0436(97) (Washington, DC, September 1997).

${ }^{178}$ Energy Information Administration, Nuclear Power Generation and Fuel Cycle Report 1997, DOE/EIA-0436(97) (Washington, DC, September 1997), Table F1.

${ }^{179}$ The Uranium Institute, The Global Nuclear Fuel Market: Supply and Demand 1995-2015 (London, June 1996), Table 8.3.
} 
Figure 16. Assumed Market Penetration of Uranium Derived from U.S. and Russian Surplus Defense Inventories, 1997-2010

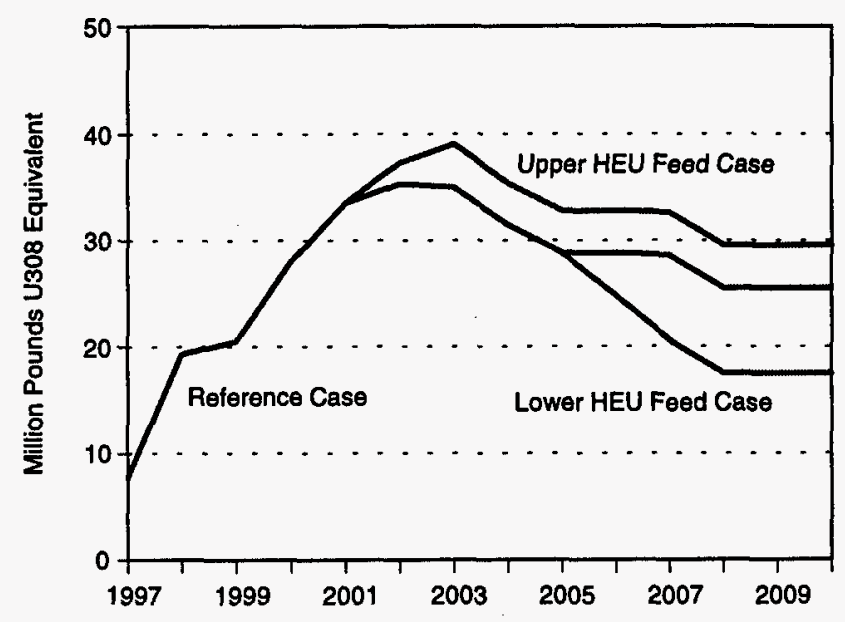

Sources: Energy Information Administration, input data used in Uranium Market Model, runs 1997_60, 1997_73, and 1997_82 (July 1997).

Western demand for uranium over the forecast period is anticipated to be met by Western production, CIS imports, commercial inventories, and U.S. and Russian surplus defense inventories (Table 14). The relative importance of these sources is expected to change by early in the next decade. Excess commercial inventories, built up largely through the accumulation of CIS imports, have contributed to a decline in uranium prices, falling below $\$ 11.00$ per pound $\mathrm{U}_{3} \mathrm{O}_{8}$ during $1997 .{ }^{180}$ (The average spot-market price for the restricted U.S. market was $\$ 15.57$ per pound $\mathrm{U}_{3} \mathrm{O}_{8}$ in $1996 .{ }^{181}$ ) Excess inventories and CIS imports are projected to supply the Western market with about 52.0 million pounds $\mathrm{U}_{3} \mathrm{O}_{8}$ in 1997, or about 35 percent of projected 1997 Western requirements.

The CIS is not expected to continue exporting uranium at levels higher than its annual production, which is assumed to be between 10 and 13 million pounds $\mathrm{U}_{3} \mathrm{O}_{8}$. With fewer CIS imports available to the market, commercial inventories (excluding uranium supplied from surplus defense inventories) are anticipated to be drawn down by early in the next decade, to levels no longer considered as excessive. The decline in CIS imports and excess commercial inventories will be offset in part by the introduction of U.S. and Russian surplus defense inventories.

The gap between current levels of uranium mine production and projected reactor requirements is not anticipated to be closed by the sales of surplus defense inventories. In all three cases, additional uranium mine production would be required to meet demand. To induce production from higher cost operations, the price of uranium would have to increase.

An example of higher cost uranium production in the Western world can be found in the United States. Little U.S. production could be supported at prices below $\$ 11.00$ per pound $\mathrm{U}_{3} \mathrm{O}_{8}$ (Figure 17). Because producers hold either longer term contracts for prices higher than the prevailing spot-market price or contracts matched with equal amounts of relatively low-price Russian uranium, U.S. production for 1997 did not decline appreciably from 1996 output. ${ }^{182}$ (U.S. production was 5.6 million pounds $\mathrm{U}_{3} \mathrm{O}_{8}$ in 1997 compared to 6.3 million pounds $\mathrm{U}_{3} \mathrm{O}_{8}$ in $1996 .{ }^{183}$ ). With an upward movement in prices, additional increments of U.S. uranium capacity could become economically feasible to operate. U.S. producers, however, would continue to compete with foreign producers, which might have lower marginal costs of production.

In the Reference and Lower HEU Feed Cases, prices are projected to rise to about $\$ 15.00$ per pound $\mathrm{U}_{3} \mathrm{O}_{8}$ in 2004 (Figure 18). Western production is projected to reach 95.6 million pounds $\mathrm{U}_{3} \mathrm{O}_{8}$ by 2005 , up from 82.1 million pounds $\mathrm{U}_{3} \mathrm{O}_{8}$ in 2000 (Table 14). Relatively low-cost production from mines in Canada and Australia is expected to contribute 68.0 million pounds $\mathrm{U}_{3} \mathrm{O}_{8}$ or 72 percent of Western production projected for 2005. The price in the Reference Case is projected to remain in a relatively narrow range through 2010 . The effects of slightly lower demand on supply near the end of the forecast period are offset by a decline in uranium supplied from U.S. surplus defense inventories. It should be noted that the price of uranium is projected in the Reference Case to remain below $\$ 16.50$ per pound $\mathrm{U}_{3} \mathrm{O}_{8}$, the price reached in mid- 1996 .

In the Lower HEU Feed Case, Western production is projected to rise to 102.4 million pounds $\mathrm{U}_{3} \mathrm{O}_{8}$ in 2010 as the supply of Russian feed is reduced. The uranium

\footnotetext{
${ }^{180}$ TradeTech, The NUCLEAR Review (October 1997).

181 Ibid.

${ }^{182}$ Matched sales contracts combine relatively high-price U.S. uranium with equal amounts of relatively low-price Russian uranium, effectively making the price of U.S. uranium more competitive in the marketplace.

${ }^{183}$ Energy Information Administration, Uranium Industry Annual 1997, DOE/EIA-0478(97) (Washington, DC, April 1998 ), Table 5.
} 
Table 11. Assumed Market Penetration of U.S. and Russian Surplus Defense Inventories in the Uranium Market, 1997-2010, Lower HEU Feed Case

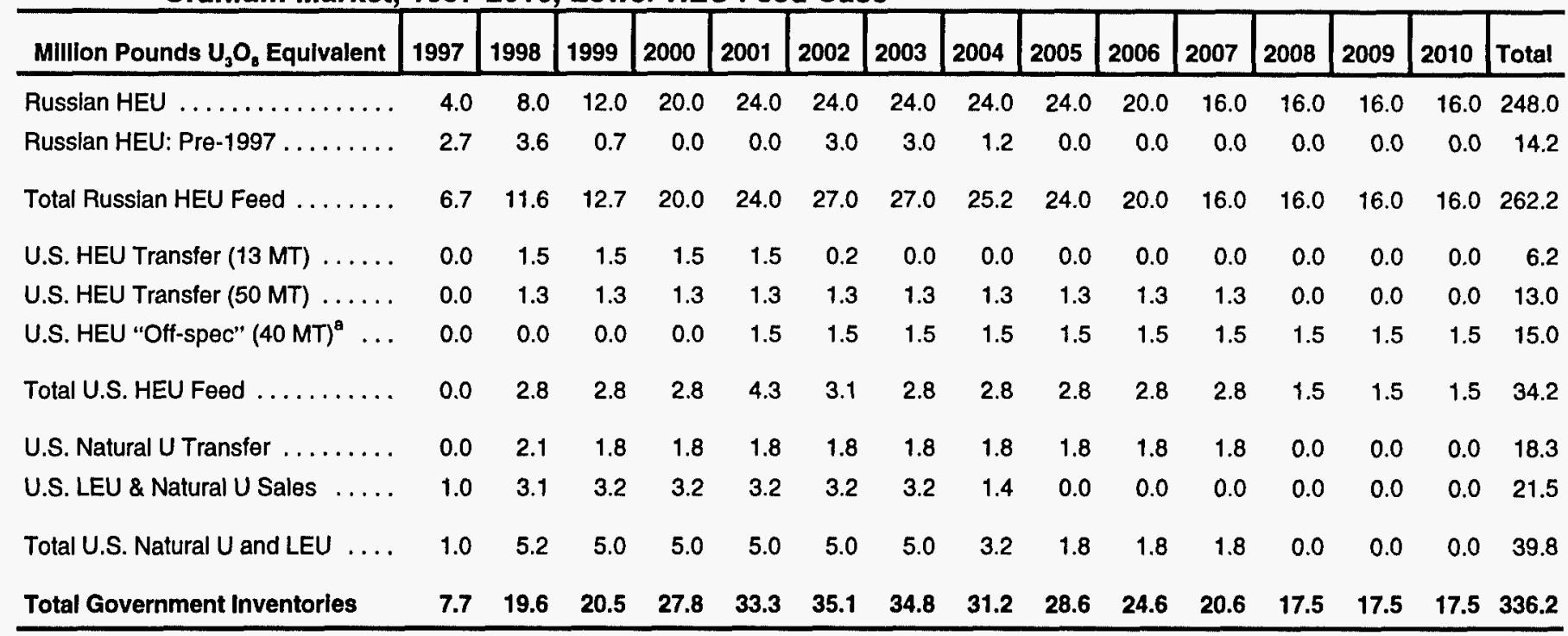

Assumptions: Russia will take back 8.0 million pounds $\mathrm{U}_{3} \mathrm{O}_{8}$ of Russian feed per year for internal use, beginning in 2002. Sales of Russian feed are assumed to remain at 24 million pounds per year until 2006, due to the availability of Russian feed not sold in previous years. See Table 7-1 for assumptions used in determining the amount of uranium contained in the surplus inventories.

a Since the analysis was completed, the U.S. Department of Energy has revised the quantity and timing for the commerclalization of "off-spec" HEU. These changes are anticipated to have only a marginal impact on projections of supply and spot-market price.

$M T=$ Metric tons.

Sources: Uranlum contalned in LEU blended down from Russian HEU (Russian feed) and transfer of natural uranium-Energy Resources International, Inc., 1997 Nuclear Fuel Cycle Supply and Price Report (Washington, DC, May 1997); uranium contained in U.S. HEU feed-R. Schmldt, personal correspondence (HEU Disposition Program Office, Oak Ridge, TN, September 24, 1997); uranium contained in proposed sales of LEU and natural uranium by DOE-U.S. Department of Energy, Office of Nuclear Energy, Science and Technology, Environmental Assessment DOE Sale of Surplus Natural and Low Enriched Uranium, DOE/EA-1172 (Washington, DC, October 1996).

price is projected to rise to between $\$ 16.50$ and $\$ 17.00$ per pound $\mathrm{U}_{3} \mathrm{O}_{8}$ between 2007 and 2010 (Figure 18). Higher cost capacity in the United States, South Africa, and other countries would be utilized at this level of price (Table 14). Due to the price increase, annual U.S. production is projected to increase from 8.2 million pounds $\mathrm{U}_{3} \mathrm{O}_{8}$ in 2005 to 11.0 million pounds $\mathrm{U}_{3} \mathrm{O}_{8}$ by 2010. In comparison, U.S. production is projected in the Reference Case to reach 8.5 million pounds $\mathrm{U}_{3} \mathrm{O}_{8}$ per year by 2010 .

With a higher assumed Russian feed supply, the price in the Upper HEU Feed Case is projected to be between $\$ 14.00$ and $\$ 15.00$ per pound $\mathrm{U}_{3} \mathrm{O}_{8}$ from 2003 through 2010 (Figure 18). In the case, the increased supply of Russian feed would displace 4.0 million pounds $\mathrm{U}_{3} \mathrm{O}_{8}$ of Western production.

\section{Potential Market Effects of Additional Commercialization}

It is likely that other surplus defense inventories could be made available after 2000. Because the UMM analysis cases consider only those quantities and schedules under approved commercialization plans, additional penetration of surplus defense inventories into the market could further displace demand for newly produced uranium. Since DOE's Record of Decision for HEU disposition (see page 29) considers up to 200 metric tons of HEU for commercial use, DOE could sell or transfer additional quantities of HEU before 2010. Additional disposition of U.S. HEU could contribute the equivalent of 1 to 2 million pounds $\mathrm{U}_{3} \mathrm{O}_{8}$ to the market per year. If approved, the irradiation of U.S. weapons-usable plutonium as MOX fuel by commercial nuclear power reactors also could displace the demand for the equivalent of 1 to 2 million pounds $\mathrm{U}_{3} \mathrm{O}_{8}$ per year beginning in 2007 . The penetration of these additional quantities of uranium and plutonium derived from surplus defense inventories would be expected to place slight downward pressure on prices, with spot-market prices falling in the range between the Reference Case and Upper HEU Feed Case shown in Figure 18.

The rate at which Russian weapons-grade HEU is scheduled to be blended down is much greater than that 
Table 12. Assumed Market Penetration of U.S. and Russian Surplus Defense Inventories in the Uranium Market, 1997-2010, Upper HEU Feed Case

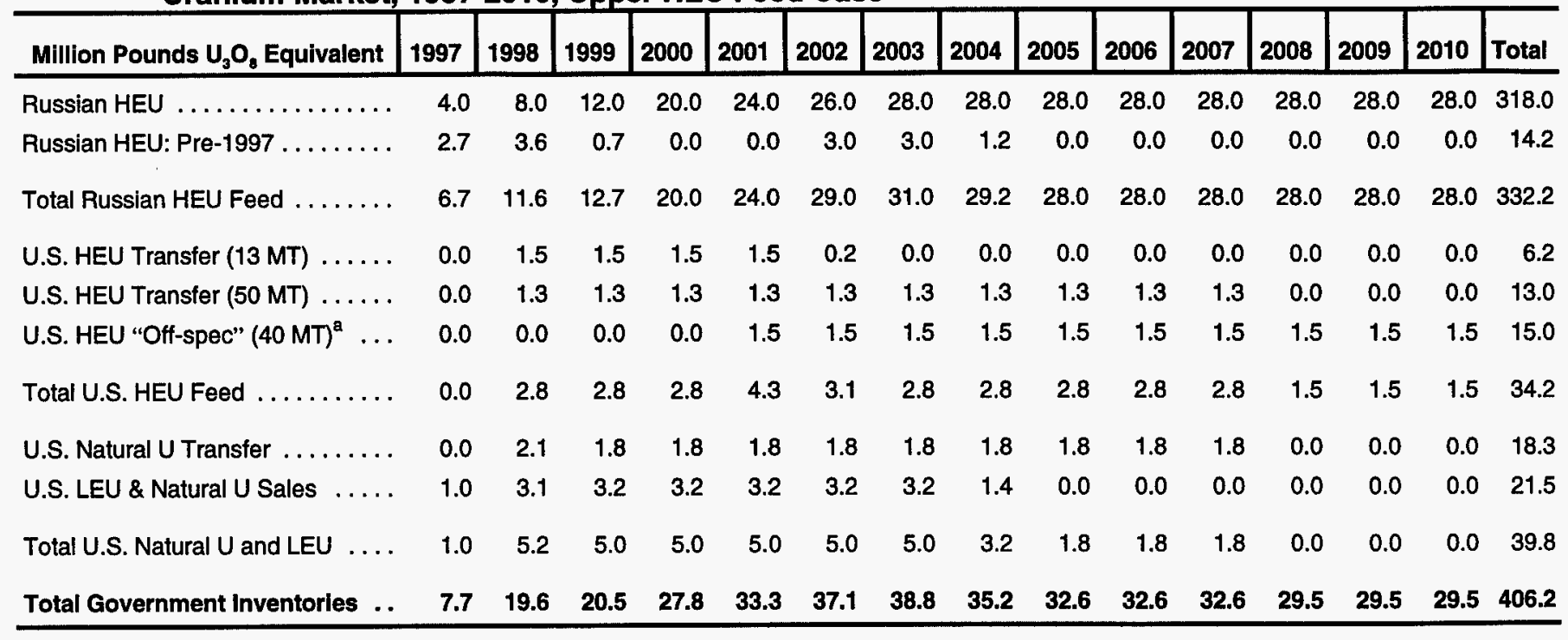

Assumptions: Russian feed will be sold in excess of 24 million pounds $\mathrm{U}_{3} \mathrm{O}_{8}$ equivalent per year, beginning in 2002. Sales of Russian feed are assumed to remain at 28 million pounds per year beginning in 2003 . See Table 7-1 for assumptions used in determining the amount of uranium contained in the inventories.

a Since the analysis was completed, the U.S. Department of Energy has revised the quantity and timing for the commercialization of "off-spec" HEU. These changes are anticipated to have only a marginal impact on projections of supply and spot-market price.

MT=Metric tons.

Sources: Uranium contained in LEU blended down from Russian HEU (Russian feed) and transfer of natural uranium-Energy Resources International, Inc., 1997 Nuclear Fuel Cycle Supply and Price Report (Washington, DC, May 1997); uranium contained in U.S. HEU feed-R. Schmidt, personal correspondence (HEU Disposition Program Office, Oak Ridge, TN, September 24, 1997); uranium contained in proposed sales of LEU and natural uranium by DOE-U.S. Department of Energy, Office of Nuclear Energy, Science and Technology, Environmental Assessment DOE Sale of Surplus Natural and Low Enriched Uranium, DOE/EA-1172 (Washington, DC, October 1996).

Table 13. Projected Uranium Requirements for 2000,2005 , and 2010 Million Pounds $\mathrm{U}_{3} \mathrm{O}_{8}$

\begin{tabular}{|c|c|c|c|}
\hline \multirow[b]{2}{*}{ Year } & \multicolumn{2}{|c|}{$\begin{array}{c}\text { PCINM } 1997 \\
\text { Reference Case }\end{array}$} & \multirow{2}{*}{$\begin{array}{l}\text { Western } \\
\text { World With } \\
\text { MOX Use } \\
\text { (This } \\
\text { Analysis) }\end{array}$} \\
\hline & World & $\begin{array}{c}\text { Western } \\
\text { World }\end{array}$ & \\
\hline $2000 \ldots$ & 158.7 & 139.3 & 134.4 \\
\hline $2005 \ldots$ & 165.7 & 143.2 & 136.4 \\
\hline $2010 \ldots$ & 164.9 & 141.5 & 133.5 \\
\hline
\end{tabular}

MOX=mixed oxide fuel.

Note: Western World does not include China or the Commonwealth of Independent States.

Sources: Total and Western world uranium requirements-Energy Information Administration, International Nuclear Model PC Version (PCINM), "Reference Case 1997," MOX use-The Uranium Institute, The Global Nuclear Fuel Market: Supply and Demand 19952015 (1996), Table 8.3. for U.S. inventories (Table 9). This discrepancy could place pressure on the United States to accelerate the blending down of its surplus HEU to match Russian efforts. U.S. law, however, does not permit commercialization activities that would adversely affect the domestic uranium industry. Also, it is not likely that Russia would favor any sizeable increases in the amount of surplus defense uranium made available to the market. Oversupply of uranium would result in depressed prices, a situation that would create an unfavorable economic situation for any supplier. More likely, the United States and Russia, through the IAEA, would agree to a mutually acceptable process for verifying that HEU declared as surplus could not be reused for weapons. Thus, any additional U.S. commercialization efforts are expected to make only marginal quantities of uranium available to the market through 2010.

\section{Enrichment Services Market}

The market penetration factors for enrichment services are different from those for $\mathrm{U}_{3} \mathrm{O}_{8}$, in that there are fewer restrictions on the enrichment component from surplus 
Table 14. Projected Supply for Western Reactor Requirements in the Lower HEU Feed Case, 2000, 2005, and 2010 (Million Pounds $\mathrm{U}_{3} \mathrm{O}_{8}$ Equivalent)

\begin{tabular}{|c|c|c|c|}
\hline & 2000 & 2005 & 2010 \\
\hline Western Production .. & 82.1 & 95.6 & 102.4 \\
\hline Australia & 22.3 & 26.4 & 28.0 \\
\hline Canada & 35.0 & 42.0 & 42.0 \\
\hline Central Africa $^{a}$ & 4.0 & 2.0 & 2.0 \\
\hline Namibia .......... & 7.0 & 10.0 & 10.0 \\
\hline South Africa ........ & 3.0 & 3.0 & 4.2 \\
\hline United States . . . . . . & 7.8 & 8.2 & 11.0 \\
\hline Other $^{b} \ldots .$. & 3.0 & 4.0 & 5.2 \\
\hline CIS Production . . & 12.0 & 12.0 & 13.5 \\
\hline China Production & 1.5 & $0.0^{c}$ & 0.0 \\
\hline \multicolumn{4}{|l|}{ Surplus Defense } \\
\hline Inventories & 27.8 & 28.6 & 17.5 \\
\hline Russian HEU & 20.0 & 24.0 & $16.0^{d}$ \\
\hline U.S. HEU, LEU, and U & 7.8 & 4.6 & 1.5 \\
\hline $\begin{array}{l}\text { Commercial } \\
\text { Inventories . }\end{array}$ & 11.0 & $0.0^{\circ}$ & 0.0 \\
\hline Total Supply ... . & 134.4 & 136.4 & 133.5 \\
\hline
\end{tabular}

${ }^{a}$ Higher cost production supported by contract commitments from France.

Includes production centers in Western Europe, Latin America, India, Mongolia, and Pakistan.

${ }^{c}$ China is expected to use its production for domestic reactor requirements.

${ }^{d}$ Russia is assumed to take back for internal uses onethird of the equivalent 24 million pounds $\mathrm{U}_{3} \mathrm{O}_{8}$ feed contained in the LEU produced from Russian HEU (Russian HEU feed).

In 2005, 24 million pounds $\mathrm{U}_{3} \mathrm{O}_{8}$ equivalent of Russian HEU feed are assumed to be sold from inventories held by Western commercial firms. In this analysis, however, sales of uranium derived Russian HEU are counted under surplus defense inventories.

$\mathrm{CIS}=$ Commonwealth of Independent States. CIS uranium exporters include Kazakhstan, Russia, and Uzbekistan.

Note: Totals may not equal sum of components because of independent rounding.

Source: Energy Information Administration, Uranium Market Model, run 1997_60 (July 1997).

defense inventories entering the market, and excess SWU capacity is available to cover disruptions in meeting commercialization schedules. Similar to the control of the uranium feed component of LEU derived
Figure 17. Production Capability Versus Price for U.S. Uranlum Production Centers

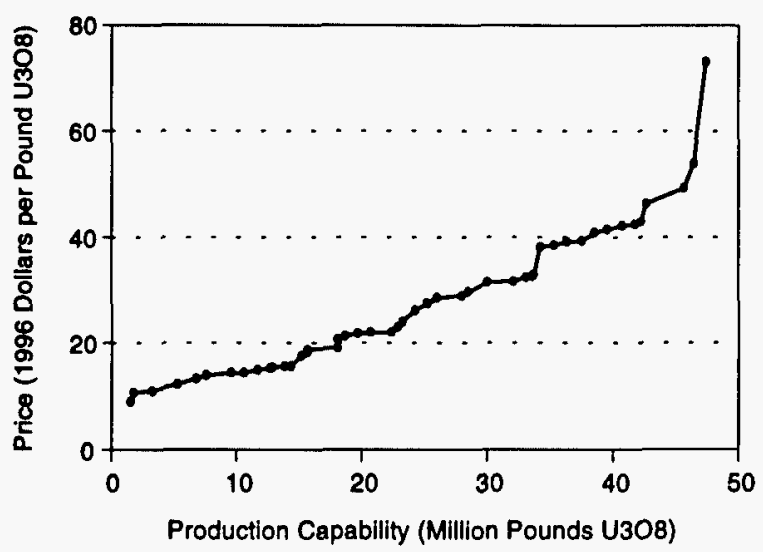

Note: Includes operating, planned, and prospective production centers.

Sources: Energy Information Administration, input data for Uranium Market Model, runs 1997_60, 1997_73, and 1997_82 (July 1997).

\section{Figure 18. Projected Spot-Market Prices In the Restrlcted U.S. Uranlum Market,} 1997-2010

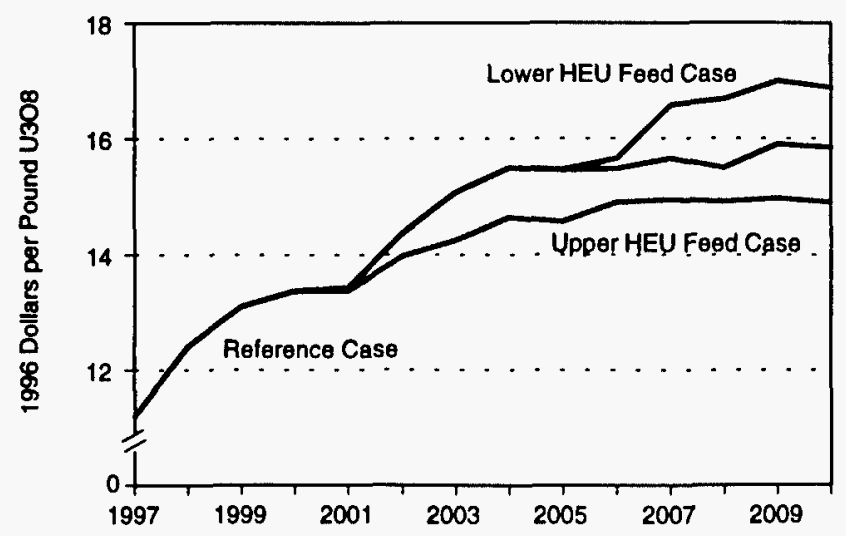

Note: A two-tiered market was developed at the end of 1992 as a result of the suspension agreements that restrict U.S. imports from the Commonwealth of Independent States.

Sources: Energy Information Administration, Uranium Market Model, runs 1997_60,1997_73, and 1997_82 (July 1997).

from Russian HEU, most of the enrichment from surplus defense inventories will be controlled by one producer.

The following analysis does not consider the potential effects of deploying the advanced vapor laser isotope 
separation (AVLIS) technology on uranium and enrichment service requirements. Although USEC plans to deploy AVLIS by 2005, additional work will be required to ensure its commercial operation. ${ }^{184}$

\section{Control of Enrichment from Surplus Defense Inventories}

Most of the enrichment contained in surplus defense inventories is expected to be made available to USEC from the blending down of Russian and U.S. HEU. The transfer of off-specification HEU from DOE to the Tennessee Valley Authority (TVA) represents the only significant amount of enrichment from surplus defense inventories that would not be controlled by USEC under current disposition plans. The utilization of off-specification HEU could provide TVA with LEU over a 10-year period (see Chapter 5). As a result, TVA would avoid purchasing up to 4.3 million SWU from the commercial market.

Under the Russian HEU Agreement, USEC is expected to purchase 92 million SWU, or about 90 percent of the enrichment contained in surplus defense inventories currently undergoing commercialization. This includes the SWU contained in the slightly enriched tails used as a blendstock in Russia-uranium that would not likely be sold in the Western market were it not for its use in blending down the HEU. USEC acquired 3.3 million SWU from Russia before 1997. By 1999, increased purchases of LEU from Russia will provide USEC with 5.5 million SWU per year.

In meeting its legal responsibility as the U.S. Executive Agent for the Russian HEU Agreement, USEC is committed to purchase the enrichment (SWU) component of LEU derived from Russian HEU. This purchase is not expected to contribute to profits. In its 1996 annual report, USEC reported that increased SWU purchases from Russia contributed to the higher costs of providing enrichment services. ${ }^{185}$ With exclusive access to the SWU component of LEU derived from Russian HEU, USEC would be expected to structure sales of SWU in a market-neutral manner so as not to depress market price. However, USEC could find it difficult to offset the higher costs of providing enrichment services by raising the price of SWU sold to its customers under the current conditions of world production overcapacity (see below).
The USEC Privatization Act directed DOE to transfer without cost to USEC up to 7,000 metric tons of natural uranium and about 50 metric tons of HEU (see Chapter 5). Pursuant to the Energy Policy Act of 1992, DOE began transferring 13 metric tons of U.S. surplus HEU without cost to USEC in 1994. The probable utilization of the transferred uranium by USEC to supply enriched uranium product is described in a later section of this chapter. The transfer of U.S. surplus defense uranium has also enhanced the USEC's value, thereby making USEC more attractive for privatization.

When completed, the DOE transfers of HEU will supply USEC with LEU equivalent to 5.7 million SWU of enrichment. This analysis does not consider the SWU content of the commercial-grade blendstock that would have been sold in the market regardless of the decision to blend down HEU. As with LEU purchased under the Russian HEU Agreement, USEC could meet its commitments to provide utilities with enrichment services by delivering LEU derived from U.S. HEU instead of utilizing production capacity.

\section{Fewer Restrictions on Selling SWU Derived from Surplus Defense Inventories}

The commercial sale of enrichment contained in LEU derived from Russian HEU is not restricted by law. In November 1995, USEC made its first delivery to a U.S. utility of SWU contained in LEU derived from Russian HEU. However, USEC is limited by the USEC Privatization Act to deliveries of no more than 800,000 SWU SWU per year beginning in 1998 from the 50 metric tons of U.S. surplus HEU that was transferred from DOE.

Since more than 90 percent of the enrichment scheduled to be made available from surplus defense inventories will be contained in LEU blended down from Russian $\mathrm{HEU}$, the restrictions on deliveries to U.S. end users of LEU from blended down U.S. HEU should have only a marginal effect on the market. In contrast, deliveries of the equivalent natural uranium components from both U.S. and Russian blended-down HEU are restricted. Thus, USEC's sales strategy would provide the principal means to ensure the orderly penetration into the marketplace of enrichment derived from surplus defense inventories.

\footnotetext{
${ }^{184}$ United States Enrichment Corporation, "USEC Completes Successful Plant-Scale Test Series of Its Next Generation Uranium Enrichment Technology" news release (December 22, 1997).

${ }^{185}$ United States Enrichment Corporation, 1996 Annual Report, p. 11.
} 


\section{Excess in Worldwide Enrichment Services Capacity}

Current worldwide enrichment services capacity of around 49 million SWU per year is more than adequate to cover projected requirements (Figure 19, "current capacity"). ${ }^{186}$ In comparison, EIA projects worldwide annual requirements in its reference case to be between 33.6 million SWU and 37.1 million SWU through 2010. ${ }^{187}$ However, restrictions on Russian imports effectively reduce the amount of enrichment that could be supplied to the entire world. Without an additional agreement

\section{Figure 19. Worldwide Enrichment Supply Capability Under Different Capacity Assumptions, No Surplus Defense Inventories Available, 1997-2010}

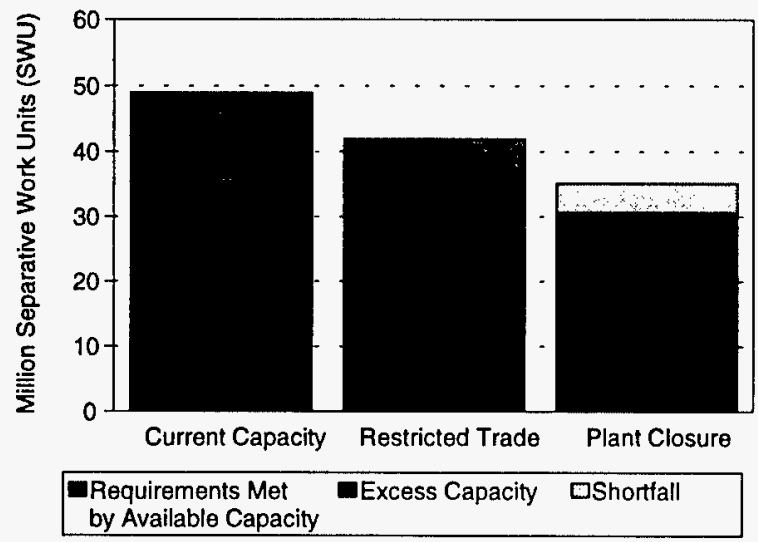

Assumptions: Restricted Trade-Russian enrichment limited by U.S. and Western European trade restrictions to 20 percent of worldwide requirements; 7 million SWU capacity per year not utilized. Plant Closure-In addition to Restricted Trade, the United States Enrichment Corporation (USEC) closes one of its gaseous diffusion plants, further reducing available capacity by 11.3 million SWU per year. For this analysis, the reduction in capacity is assumed to equal the full capacity of USEC's larger plant.

Sources: World enrichment capacity-NAC International, Nuclear Industry Status Report on Enrichment, A Fuel-Trac Product (Norcross, GA, February 1997), Table B-3.1; Requirements-Energy Information Administration, International Nuclear Model (PC Version), File INM.WK4, Reference Case 1997. between the United States and Russia, U.S. imports of Russian enrichment would be limited to the SWU purchased by USEC through the Russian HEU Agreement. As described in Chapter 6, imports of Russian uranium are also restricted by the European Union. If it is assumed that Russian imports would be limited to 20 percent of world requirements, the world supply capability would be reduced by about 7 million SWU or 14 percent (Figure 19, "Restricted Trade").

Some of the excess SWU capacity could be closed. Gaseous diffusion plants, in the United States and France, consume much more electricity than do centrifuge plants operated in other countries. USEC has reported that electricity costs represent approximately 60 percent of its production costs. ${ }^{188}$ The limited availability of less costly non-firm electric power makes alternative supply capability. For example, closure of USEC's larger capacity plant under current trade restrictions in the absence of alternative supply would cause available capacity to fall below world requirements (Figure 19, "Plant Closure").

\section{Price and Supply Outlook}

The availability of enrichment from surplus defense inventories would increase the supply available to the Western world (Figure 20). With an increase in supply capability, the price for enrichment services would be expected to decline. The average enrichment spotmarket price for the restricted U.S. market during the third quarter 1997 was $\$ 90.00$ per SWU. ${ }^{189}$ As the prime recipient of SWU from surplus defense inventories, USEC would best serve its interests by introducing the acquired SWU in a manner least disruptive to price stability. This is particularly important because the implementation of the Russian HEU Agreement has increased USEC's cost of providing enrichment services. To achieve price stability, USEC is expected to sell this material gradually through long-term contracts. In its annual report for 1996, for example, USEC states that "substantially all of the Company's revenue is derived from electric utilities pursuant to long-term uranium enrichment requirements contracts." 190

${ }^{186}$ NAC International, Nuclear Industry Status Report on Enrichment, A Fuel-TAC Product (Norcross, GA, February 1997), Table B-3.1.

${ }^{187}$ Energy Information Administration, Nuclear Power Generation and Fuel Cycle Report 1997, DOE/EIA-0436(96) (Washington, DC, September 1997), Table F3.

${ }^{188}$ United States Enrichment Corporation, 1996 Annual Report, p. 11.

189 TradeTech, The Nuclear Review (October 1997).

${ }^{190}$ United States Enrichment Corporation, 1996 Annual Report, p. 10. 
Figure 20. Worldwide Enrichment Supply Capability Under Different Capacity Assumptions, Availability of Surplus Defense Inventories Based on Uranium Reference Case, 1997-2010

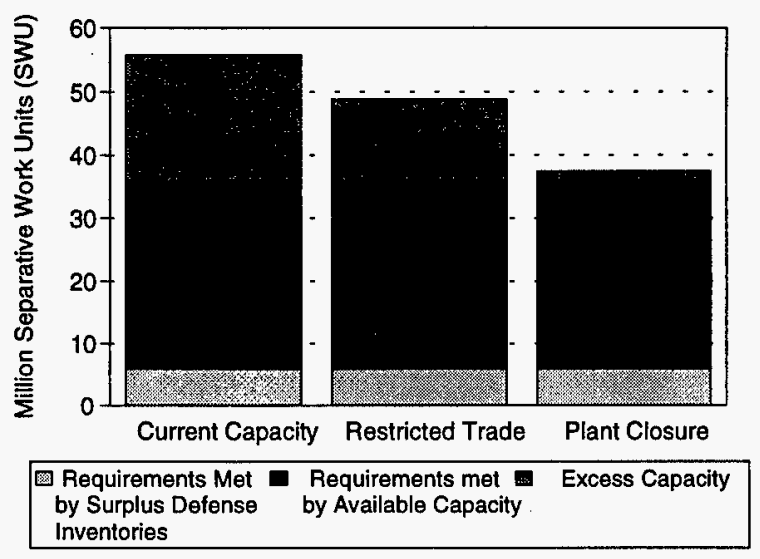

Assumptions: Restricted Trade-Russian enrichment limited by U.S. and Western European trade restrictions to 20 percent of worldwide requirements; 7 million SWU capacity per year not utilized. Plant Closure-In addition to Restricted Trade, the United States Enrichment Corporation (USEC) closes one of its gaseous diffusion plants, further reducing available capacity by 11.3 million SWU per year. For this analysis, the reduction in capacity is assumed to equal the full capacity of USEC's larger pant.

Notes: Requirements are the average projected for 1997 through 2010; no mixed-oxide (MOX) fuel displacement. Enrichment available from U.S. and Russian surplus defense HEU and LEU is 6.0 million SWU per year, the average of the amount currently scheduled for commercialization, 1997-2010.

Sources: World enrichment capacity-NAC International, Nuclear Industry Status Report on Enrichment, A Fuel-Trac Product (Norcross, GA, February 1997), Table B-3.1; Requirements-Energy Information Administration, International Nuclear Model (PC Version), File INM.WK4, Reference Case 1997.

With access to most of the SWU from surplus defense inventories, USEC may opt to stop production at one of the two gaseous diffusion plants it leases from DOE. The availability of less costly non-firm power could play an important role in identifying a plant for possible closure. Other factors include the possibility that a plant would require significant capital expenditure in the near term to replace aging equipment. However, USEC is not likely to implement any possible closure until after privatization takes place, and not before it is certain that TENEX can meet its expanded commitments for delivering LEU derived from Russian HEU. Should USEC close its larger capacity plant and Russian imports continue to be limited to 20 percent of world requirements, the capability to supply SWU from U.S. and Russian surplus defense inventories and remaining production capacity would be adequate to cover projected world demand (Figure 20). Nevertheless, this substantial reduction in excess production capacity could result in an increase in the price of SWU as less lower cost production would be available to meet demand. In this scenario, USEC would be more likely to pass through to the customer its costs incurred as U.S. Executive Agent for the Russian HEU Agreement.

\section{Enriched Uranium Product}

\section{Supply and Demand Factors}

The ability to produce competitively priced enriched uranium product (EUP) would position an enricher as a marketer of uranium, as well as a provider of enrichment services. To produce EUP, an enricher requires competitively priced natural uranium feed and available enrichment capacity. As with enrichment services, enrichers are likely to sell EUP through longer term contracts rather than on the spot market. However, the demand for EUP is expected to be limited in the near term, because utilities have covered most of their requirements with long-term contracts for enrichment services. For example, only about 5 percent of the equivalent quantity of $\mathrm{U}_{3} \mathrm{O}_{8}$ contracted for delivery to U.S. utilities in 1996 was in the form of EUP. ${ }^{191}$ Nevertheless, the demand for EUP is likely to increase as long-term contracts for enrichment services are completed.

The demand for EUP by nuclear power generating companies could be enhanced in response to the restructuring of the electric power industry. The purchase price paid by a customer for EUP includes the natural uranium feed component as well as the enrichment. ${ }^{192}$ Because the $\mathrm{U}_{3} \mathrm{O}_{8}$, conversion, and enrichment steps are eliminated for the fuel procurement process, access to EUP could provide nuclear power generating companies with greater flexibility in supplying fuel for reactors. This would be especially important to electric power generating companies with nuclear assets if they are employing such revenue maximization strategies as matching fuel reloading with periods of off-peak

\footnotetext{
${ }^{191}$ Energy Information Administration, Uranium Industry Annual 1996, DOE/EIA-0478(96) (Washington, DC, April 1997), Table 13.

${ }^{192}$ Energy Information Administration, World Nuclear Outlook 1995, DOE/EIA-0436(95) (Washington, DC, October 1995), p. 35.
} 
demand or optimizing the most cost-efficient fuel mix. Due to restructuring, companies could find it increasingly difficult to pass increased costs, including fuel, through to customers.

Nuclear power generating companies also will be looking to reduce uranium holding costs for both economic and regulatory reasons. As the electric power industry moves toward competitive markets, public utility commissions could increase regulatory oversight of fuel costs as they authorize utilities to recover potentially strandable costs. ${ }^{193,194}$ As a result, the owners of nuclear power plants could be restricted in their recovery of out-of-core inventory holding costs. ${ }^{195}$

\section{Outlook}

The opportunity to market EUP could be especially important to USEC. When completed, transfers of HEU and natural uranium from DOE under the USEC Privatization Act will provide USEC with the equivalent of 37.6 million pounds $\mathrm{U}_{3} \mathrm{O}_{8}$ and 6.3 million SWU. In comparison, uranium and enrichment requirements for U.S. nuclear power reactors in 1998 are projected to be 49.4 million pounds $\mathrm{U}_{3} \mathrm{O}_{8}$ and 11.0 million SWU, respectively. ${ }^{196}$

Although revenues could be realized from the sale of natural uranium, USEC is more likely to use the natural uranium as feed to produce EUP. Unlike Cogema, a uranium producer and provider of integrated nuclear fuel cycle services, USEC does not own mines and conversion facilities that could supply natural uranium feed. The acquisition of enrichment contained in U.S. and Russian surplus defense inventories would allow USEC to use its enrichment capacity to produce EUP. Because of limitations on the availability of relatively inexpensive electric power, not all of USEC's gaseous diffusion enrichment capacity is considered economical to operate. However, by using LEU received from the blending down of U.S. and Russian HEU to fill contracts for enrichment services (rather than feeding the enrichment plant with uranium delivered by customers),
USEC could make economical capacity available for the production of EUP.

Because of the recent suspension in negotiations between Western suppliers and MINATOM, Cogema is not expected to purchase any of the uranium feed contained in LEU derived from Russian HEU in the near term. ${ }^{197}$ Such a purchase would have added to its portfolio of competitively priced uranium supply, which includes relatively low-cost mines in Canada. However, Cogema, unlike USEC, does not have access to LEU that could be used to fill existing enrichment services contracts. Thus, Cogema would not be expected to increase EUP output by utilizing the economical capacity of its gaseous diffusion plant without reducing its capability to provide competitive enrichment services.

As described in Chapter 6, Russia is likely to take back some natural uranium feed for use in blending down HEU and to meet domestic requirements and export commitments. The use of uranium feed as a blendstock for HEU blending could free up enrichment capacity that would have been used to enrich tails for similar use. Also, restrictions on Russian imports described above have created additional unused capacity. While access to the natural uranium feed component of LEU derived from Russian HEU would provide Russia with both feed and the ability to utilize additional enrichment capacity, trade restrictions limit the penetration of Russian EUP in the Western market. Nevertheless, China and Japan could be important customers in the long term based on expected growth in nuclear fuel requirements and improving relations, respectively.

\section{Projected Uranium Cost Savings to Nuclear Power Generating Companies}

From the Reference Case analysis presented in this chapter, the spot-market price of $\mathrm{U}_{3} \mathrm{O}_{8}$ in 1996 dollars is projected to rise to $\$ 15.90$ per pound $\mathrm{U}_{3} \mathrm{O}_{8}$ by the end of the next decade. While exceeding the depressed price level of the mid-1990s, the projected spot-market price

\footnotetext{
${ }^{193}$ J. Sellers, "Strategies for Competition and Nuclear Fuel," paper presented at the Nuclear Energy Institute's FuelCycle 97 conference (Atlanta, GA, April 1997), p. 6.

194 "Stranded" or "strandable" costs are electric power generation costs likely to become unrecoverable in a competitive electric power marketplace.

195 J. Sellers, "Strategies for Competition and Nuclear Fuel," paper presented at the Nuclear Energy Institute's FuelCycle 97 conference (Atlanta, GA, April 1997), p. 6.

${ }^{196}$ Energy Information Administration, Nuclear Power Generation and Fuel Cycle Report 1997, DOE/EIA-0436(97) (Washington, DC, September 1997), Tables F1 and F3.

${ }^{197}$ Cameco Corporation, "Discussions Suspended Concerning Russian Highly Enriched Uranium," press release (December 11, 1997).
} 
trend falls well below pre-1990 historical highs (Figure 21). The anticipated penetration into the marketplace of U.S. and Russian surplus defense inventories would displace relatively higher cost $\mathrm{U}_{3} \mathrm{O}_{8}$ production that would have been required to fill the gap between the current level of production and projected Western demand. As described in the "Uranium Price and Supply Outlook" section of this chapter (page 62), surplus defense inventories are expected to overtake commercial inventories and CIS imports to become the second most important source of uranium supply, behind newly produced uranium. Presumably, the market penetration of surplus defense inventories will benefit nuclear power generating companies by reducing their fuel procurement costs.

Figure 21. Average Price of U.S.- and ForeignOrigin Uranium Delivered to U.S. Utilities from Domestic Suppliers Versus Average Spot-Market Price, 1982-1996

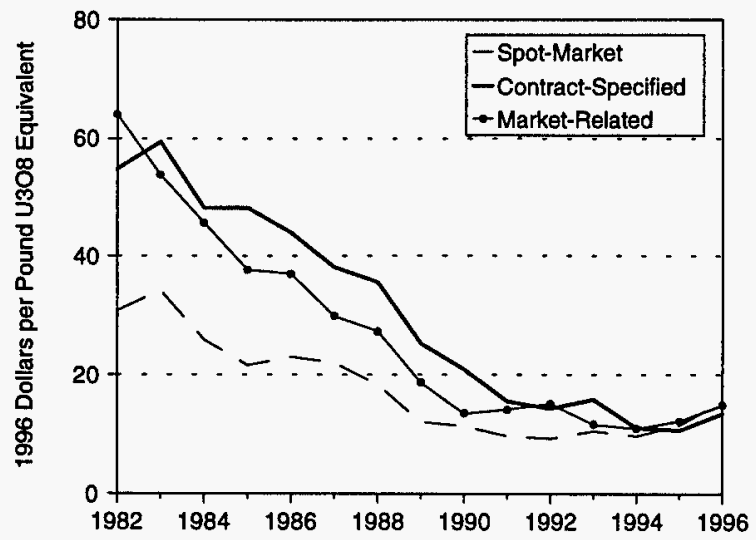

Sources: Spot-market price-annual average of Exchange Value reported in TradeTech, The NUCLEAR Review (October 1997); all other prices-Energy Information Administration, Uranium Industry Annual, 1993 , DOE/EIA0478(93) (Washington, DC, September 1993), Table 28; and Uranium Industry Annual 1996, DOE/EIA-0478(96) (Washington, DC, April 1997), Table 14.

\section{Uranium Market Analysis Scenarios}

To assess the potential savings in uranium procurement costs that could be realized by nuclear power generating companies, three scenarios were modeled in which surplus defense inventories are not considered available for use in producing commercial nuclear fuel. For the base No Surplus Defense (NSD) scenario, Western production centers were assumed to operate under the same schedules that were used for the three cases described earlier in this chapter. Current schedules for opening new mines coincide with the anticipated depletion of existing mines. Even without the anticipated market penetration of surplus defense inventories, these schedules could be realistic in view of the historical oversupply in uranium brought about by excess commercial inventories and CIS imports.

For the NSD scenario, Russia is assumed to continue meeting its longstanding delivery commitments to Eastern European countries, and to continue its exports to the United States. After the current Suspension Agreement with Russia ends in 2003, U.S. imports of Russian uranium are assumed to continue at a rate of 4.3 million pounds $\mathrm{U}_{3} \mathrm{O}_{8}$ per year. As described in Chapter 6 , internal reactor requirements and export deliveries are likely to diminish Russian inventories of commercial natural uranium and LEU to levels below the Russian government's strategic requirements. To meet demand in the absence of blending down HEU, it is assumed that Russia will increase production from its mines. Viktor Mikhailov, former Minister of MINATOM, had stated that Russia intends to increase production from the current rate of about 5 million pounds $\mathrm{U}_{3} \mathrm{O}_{8}$ per year to about 28 million pounds $\mathrm{U}_{3} \mathrm{O}_{8}$ per year by $2010 .{ }^{198}$ While it is not certain how much of this projected output would be sustainable in a market economy, Russia is likely to have the capability to increase its uranium production to some extent.

To analyze the sensitivity of uranium spot-market price to uncertainties in supply, two additional scenarios, NSD-new discovery and NSD-restrictive policy, also were considered for the analysis of projected uranium cost savings to nuclear power generating companies. The NSD-new discovery scenario was used to analyze the effects of uranium being supplied from a hypothetical discovery of low-cost reserves that had not been accounted for in the NSD scenario. The maximum production capacity for this new hypothetical discovery is assumed to be 14 million pounds $\mathrm{U}_{3} \mathrm{O}_{8}$ per year, a quantity equal to the 1997 output for Key Lake in Canada, the world's largest uranium mine. ${ }^{199}$ To allow for required government approvals, the lead time between discovery of reserves and production startup is

\footnotetext{
${ }^{198}$ V. Mikhailov, "The Nuclear Industry in Russia," in Uranium and Nuclear Energy: 1997, Proceedings of the Twenty-Second Annual Symposium of the Uranium Institute (London, September 1997), p. 166.

${ }^{199}$ Cameco Corporation, 1997 Annual Report, p. 16.
} 
assumed to be seven years. Assuming no significant delays, a discovery made in 1998 would produce at 50percent capacity in 2005 and full capacity in 2006 and subsequent years. The rate of production for the new discovery variant is modeled in the UMM as a first step of the uranium supply curve. However, this increment of supply could represent an aggregation of two or more new discoveries of low-cost reserves.

The NSD-restrictive policy scenario considers the uncertainties regarding whether or not prospective uranium mines will receive government approval to operate. This scenario assumes a hypothetical reinstatement of a former Australian government policy that had restricted uranium production to three mines. ${ }^{200}$ In early 1998, the Australian government indicated that it might call for elections to be held in the later part of $1998 .{ }^{201}$ The Australian Labor Party (ALP), a contending party, has indicated that as a ruling party it would implement restrictions on the development of new uranium mines. For this analysis, future Australian production is assumed to be limited to two currently operating mines-Olympic Dam and Ranger, and one prospective mine-Jabiluka. Also, the government policy scenario assumes that Jabiluka will receive an export license before a change in government would be implemented. Based on these assumptions, restrictions on the development of new Australian uranium mines would preclude the availability of up to 15 million pounds $\mathrm{U}_{3} \mathrm{O}_{8}$ per year that would have been sold under the No Surplus Defense scenario.

For this analysis, projections from the NSD scenario are assumed to most likely represent the supply and price trends for uranium without the commercialization of U.S. and Russian surplus defense inventories. The new discovery and restrictive policy scenarios were modeled to examine the effects of uncertain events on the availability of supply. Discoveries of new low-cost reserves made after 2003 would not likely supply uranium to the market during the forecast period. On the issue of restrictive government policies, the Australian government could become more supportive of new uranium mine development should the level of uranium spot-market price rise to that projected for the no surplus scenario. Ultimately, the effects of additional new discoveries and delays or cancellations in the startup of prospective mines due to government policies throughout the world could largely offset each other.

\section{Incremental Cost Analysis}

Transactions in the uranium market are made up of contracts of different durations. Thus, a share of future requirements is always covered by existing contracts. Rather than considering absolute prices for a multitude of contracts, this analysis focuses on the incremental change in the price of all uranium deliveries $\left(\mathrm{U}_{3} \mathrm{O}_{8}\right.$, natural $\mathrm{UF}_{6}$, and EUP) based on the movement in spotmarket price. Using data collected by EIA for the period 1982 to 1996, the change in price for contract-specific and market-related contracts between U.S. utilities and suppliers shows a close linear relationship to the change in spot-market price (Figure 21). A simple regression analysis provides statistical inferences about such a relationship. The results of the regression analysis show that much of the change in the various contract prices can be explained by a change in spot-market price (Figure 22). For example, the aggregation of contract-

\section{Figure 22. Results of Regression Analysis of the Relationship Between Contract Prices and Spot-Market Price, 1982-1996}

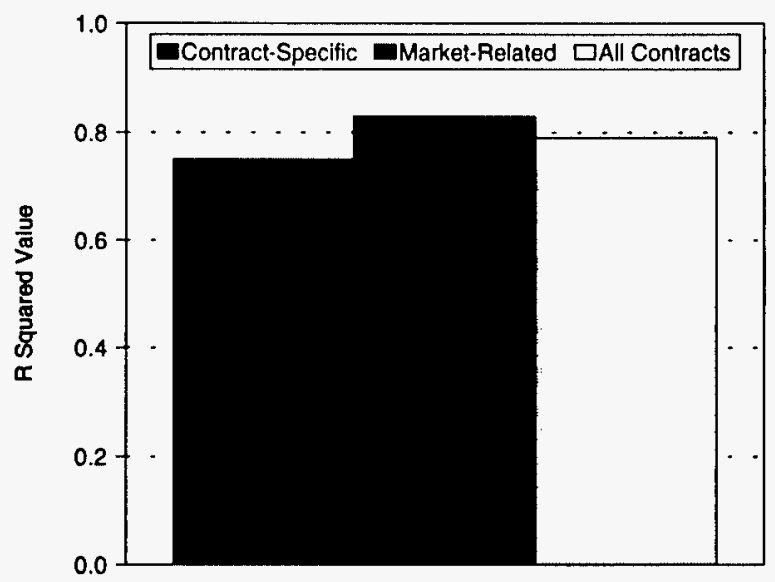

Source: Spot-market price-annual average of Exchange Value for the restricted U.S. market reported in TradeTech, The Nuclear Review (October 1997); all other prices-Energy Information Administration, Uranium Industry Annual, 1993, DOE/EIA-0478(93) (Washington, DC, September 1993), Table 28; and Uranium Industry Annual 1996, DOE/EIA0478(96) (Washington, DC, April 1997), Table 14.

${ }^{200}$ While in power between 1983 and 1996, the Australian Labor Party had implemented a policy, known as the "three-mine policy," whereby uranium production was limited to three named production centers. With the closure of Nabarlek, Australian uranium production was limited to Olympic Dam and Ranger. In 1996, the newly elected coalition of the Liberal and National parties abolished the three-mine policy.

${ }^{201}$ R. Godfrey, Counselor (Nuclear), Embassy of Australia, personal communication (April 21, 1998) 
specified and market-related contract prices was found to have an R-squared value of 0.79 percent, meaning that 79 percent of the change in contract prices can be explained by the change in spot-market prices. This relationship is especially useful, because the UMM provides forecasts of spot-market prices.

While the trend in price movements has been consistent over the last 15 years, the average prices for longer term contracts and the spot-market price converged in the 1990s (Figure 21). The decline in average contract prices with relation to the average spot-market price reflects the expiration of much higher price contracts executed in the 1970s and early 1980s. Some of these contracts were in place for 10 years or more. Because U.S. utilities are no longer burdened by higher price contracts, the average contract price for uranium is not expected to deviate appreciably from the average spot-market price projected through 2010.

From the relationship described above, it is assumed that an incremental change in projected spot-market price for $\mathrm{U}_{3} \mathrm{O}_{8}$ approximates the incremental change that would take place for the price of all uranium delivered in a given year. Without commercialization of U.S. and Russian surplus defense inventories, additional increments of uranium would have to be produced in Western countries to meet demand. The $\mathrm{U}_{3} \mathrm{O}_{8}$ spotmarket price would be expected to rise to cover the marginal cost of the more expensive increments of production required to meet demand. The incremental production would come from many regions, including Australia, Canada, Central Africa, South Africa, and the United States.

To calculate the incremental change in price for uranium delivered, the differences in projected spot-market price between the three scenarios that assume surplus defense inventories are unavailable and the Reference, Lower HEU Feed, and Upper HEU Feed cases were calculated. For example, the incremental change between the NSD scenario and the Reference Case rises from just over $\$ 1.00$ per pound $\mathrm{U}_{3} \mathrm{O}_{8}$ in 1997 to over $\$ 6.00$ per pound $\mathrm{U}_{3} \mathrm{O}_{8}$ in 2002 (Figure 23). The relatively low price differential projected over the next few years results from the availability of excess commercial inventories and CIS imports. To develop an estimate of the incremental costs savings per year, the incremental price is multiplied by EIA's projections of uranium requirements for U.S. reactors. ${ }^{202}$
Figure 23. Incremental Rise in Projected Uranium Spot-Market Price: Three No Surplus Defense Scenarios Versus Reference Case, 1997-2010

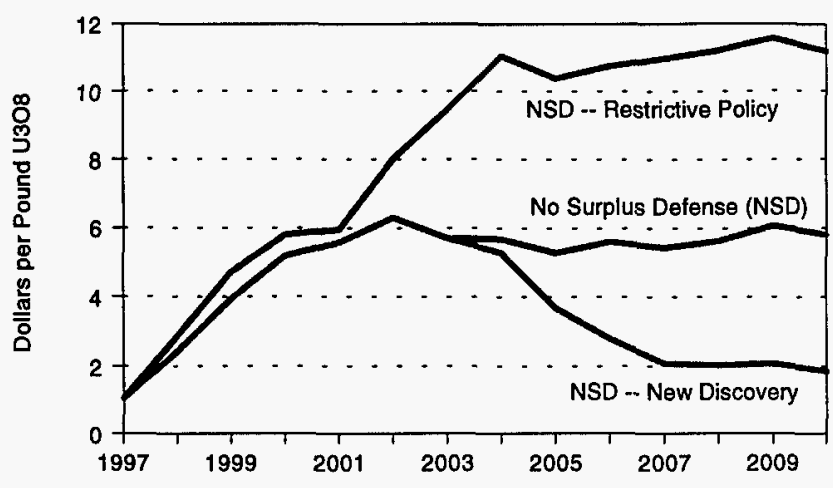

Assumptions: No Surplus Defense (NSD)-U.S. and Russian surplus defense inventories are not available as a fuel supply for commercial nuclear power reactors, and the schedules for future uranium mine production are the same as used in analyzing the effects of surplus defense inventories on uranium spot-market price; NSD-New Discovery-uranium from a hypothetical discovery of low-cost uranium reserves not accounted for in the NSD scenario is produced and sold in the market at an annual rate of 7 million pounds $\mathrm{U}_{3} \mathrm{O}_{8}$ in 2005 and 14 million pounds $\mathrm{U}_{3} \mathrm{O}_{8}$ in 2006 and subsequent years; NSD-Restrictive Policy-hypothetical reinstatement of the former Australian government's policy restricts uranium production to three mines, thereby precluding the availability of 15 million pounds $\mathrm{U}_{3} \mathrm{O}_{8}$ from potential new mines assumed to be sold in the NSD scenario.

Note: These projections show the yearly differences in price between the three No Surplus Defense scenarios and the Reference Case.

Source: Energy Information Administration, Uranium Market Model, runs 1997_73, 1997A_21, 1997A-46, and 1997A-98.

Certain assumptions made about uranium supply affect projections of uranium spot-market price. For the new discovery scenario, the incremental rise in uranium spotmarket is reduced by around $\$ 3.00$ per pound $\mathrm{U}_{3} \mathrm{O}_{8}$ when compared to the NSD scenario as an additional 14 million pounds $\mathrm{U}_{3} \mathrm{O}_{8}$ becomes available in 2005 (Figure 23). With an assumed restriction of Australian uranium output to three production centers, up to 15 million pounds $\mathrm{U}_{3} \mathrm{O}_{8}$ per year would be precluded from the market. A similar quantity of uranium from prospective Australian mines is assumed to have been sold in the NSD scenario. Thus, the estimated incremental change in uranium spot-market price for the restrictive policy scenario increases by as much as between $\$ 5.00$ and $\$ 6.00$ per pound $\mathrm{U}_{3} \mathrm{O}_{8}$ when compared to the NSD scenario (Figure 23).

\footnotetext{
${ }^{202}$ Energy Information Administration, Nuclear Power Generation and Fuel Cycle Report 1997, DOE/EIA-0436(97) (Washington, DC, September 1997), Table F1.
} 


\section{Projected Cost Savings}

Based on the analysis described above, U.S. nuclear power generating companies would incur lower fuel costs with access to competitively priced uranium from U.S. and Russian surplus defense inventories than the costs they would incur for newly produced uranium. Estimates of cumulative savings in uranium procurement costs were made for the range of supply assumptions described in the previous section on uranium market analysis scenarios (Table 15). Based on the most likely NSD scenario, the potential cumulative savings in uranium procurement costs to U.S. nuclear power generating companies through 2010 are estimated to be between $\$ 2.9$ billion and $\$ 3.4$ billion in 1996 dollars (Figure 24).

\section{Conclusions}

\section{Analytical Results}

Nonproliferation objectives and financial considerations are expected to provide the U.S. and Russian governments with considerable incentives for making surplus inventories available to the commercial nuclear fuel market. LEU derived from blending down Russian HEU has been delivered to U.S. utilities since 1995. The $\mathrm{U}_{3} \mathrm{O}_{8}$ component of this LEU began to displace uranium supplied from more traditional sources in 1997. Natural uranium $\left(\mathrm{U}_{3} \mathrm{O}_{8}\right.$ and conversion) from U.S. surplus defense inventories also began entering the market in 1997. Trade restrictions and other national policies and
Figure 24. Estimate of Most Likely Potentlal Cumulative Savings In Uranium Procurement Costs for U.S. Nuclear Power Generating Companies from the Assumed Market Penetration of U.S. and Russlan Surplus Defense Inventorles, 1997-2010

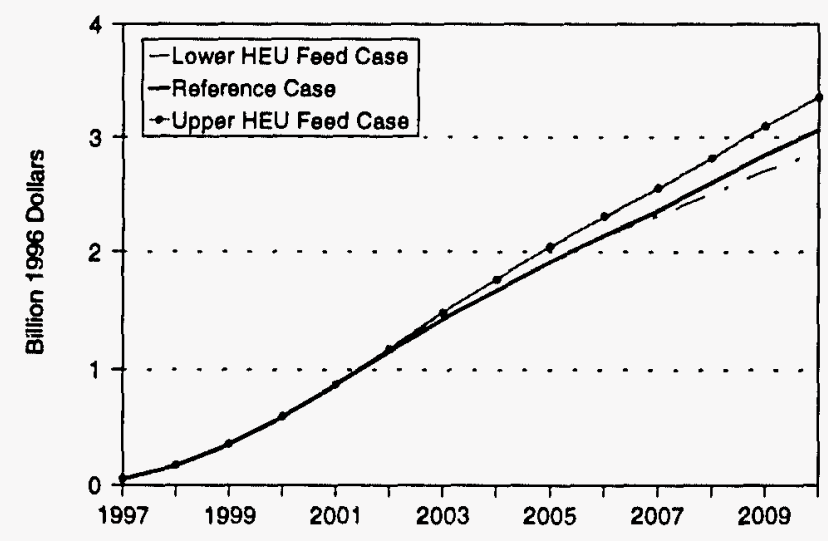

Note: It is assumed that changes in all contract prices are highly correlated to changes in the projected spot-market price. The estimation of potential cumulative savings is based on the projected decline in uranium spot-market price as a result of the penetration into the marketplace of U.S. and Russian surplus defense inventories assumed for the thre日 specific cases compared to the No Surplus Defense scenario.

Source: Projected spot-market price-Energy Information Administration, Uranium Market Model, runs 1997_60, 1997_73, 1997_82, and 1997A_21.

certain market factors, however, will limit sales of equivalent $\mathrm{U}_{3} \mathrm{O}_{8}$ from U.S. and Russian surplus defense inventories to end users in the near term. For the

Table 15. Estimates of Potentlal Cumulative Savings in Uranlum Procurement Costs for U.S. Nuclear Power Generating Companies from the Assumed Market Penetration of U.S. and Russlan Surplus Defense Inventories Based on Different Assumptions About Uranium Supply, 1997-2010 (Billion 1996 Dollars)

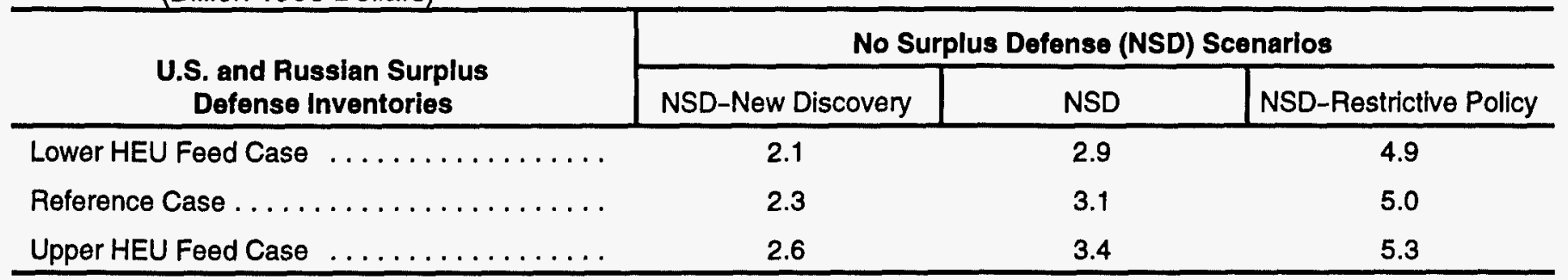

Note: It is assumed that changes in all contract prices are highly correlated to changes in the projected spot-market price. The estimation of potential cumulative savings is based on the projected decline in uranium spot-market price as a result of the penetration into the marketplace of U.S. and Russian surplus defense inventories assumed for the three specific cases (Reference, Lower HEU Feed, and Upper HEU Feed) compared to three No Surplus Defense scenarios based on various assumptions about uranium supply (No Surplus Defense (NSD), NSD-new discovery, and NSD-restrictive policy).

Source: Projected spot-market-price-Energy Information Administration, Uranium Market Model, runs 1997_60, 1997_73, 1997_82, 1997A_21, 1997A_46, and 1997A_98. 
Reference Case, the annual rate of market penetration is assumed to approximate current government commercialization schedules early in the next decade. By 2002, the equivalent of 35 million pounds $\mathrm{U}_{3} \mathrm{O}_{8}$ derived from surplus defense inventories is expected to penetrate the market annually. This quantity is approximately equivalent to the combined annual production capacity of the world's two largest uranium mines currently under development.

More than 80 percent of the uranium considered under currently scheduled commercialization programs would be supplied from the blending down of Russian HEU. This uranium is considered Russian-origin; its delivery to U.S. consumers is restricted by the USEC Privatization Act and the Suspension Agreement with Russia. As more uranium derived from Russian HEU is permitted to enter the U.S. market, the differential between the restricted and unrestricted spot-market price is expected to diminish, possibly disappearing altogether. It is not likely that reciprocity in the quantities of U.S. and Russian HEU down-blended for commercial use will be achieved by 2010 .

The U.S. Government is required by the USEC Privatization Act to determine whether its commercial sale of uranium from surplus inventories would have an adverse effect on the domestic uranium industry. The unlikely introduction of additional uranium derived from U.S. HEU at levels equivalent to the commercialization of Russian HEU would displace supply from relatively higher cost producers, including those in the United States. Because of the anticipated oversupply, Russia would be expected to realize a lower price for its uranium sales. To pursue nonproliferation objectives while at the same time not contributing to an oversupply in the commercial marketplace, it is anticipated that the United States would allow increased international inspections of its nuclear materials stockpiles through the auspices of the IAEA.

At present, a gap between Western world requirements and primary production is filled by commercial inventories and imports from the Commonwealth of Independent States. Over the next several years, surplus defense inventories are expected to become the second most important source of uranium, behind primary production. Nevertheless, an increase in primary uranium production is projected even though the annual quantity of uranium supplied from surplus defense inventories is assumed to increase. To induce additional increments of production, the spot-market price would have to rise above the marginal costs of the incremental producers.
The average annual spot-market price in the U.S. market is expected to be between $\$ 14.00$ and $\$ 17.00$ per pound $\mathrm{U}_{3} \mathrm{O}_{8}$ by the middle of next decade. The lower price would result from marginally higher rates of market penetration by the uranium feed contained in LEU derived from the blending down of Russian HEU. The higher price would result from decreased availability to Western consumers of the uranium from Russian HEU. For this analysis, Russia is assumed to take back onethird of the uranium feed in order to fill domestic requirements and longstanding supply commitments with neighboring countries. Based on estimates of marginal costs for the additional production needed to fill the Western supply shortfall, the spot-market price is projected to rise by less than $\$ 2.00$ per pound $\mathrm{U}_{3} \mathrm{O}_{8}$ from the projected price in the Reference Case. At this price level, and taking into account competition from other producers worldwide, U.S. production is projected to reach 11 million pounds $\mathrm{U}_{3} \mathrm{O}_{8}$ per year by 2010 .

The Western uranium market could be strongly affected by two events: (1) the timing and extent by which Russia makes the natural uranium feed component of HEU available to Western consumers and (2) construction deferrals and early retirements of nuclear power generating capacity. Declining nuclear power generating capacity would decrease demand for uranium. Russian use of uranium from HEU would decrease the West's supply of competitively priced uranium. Taken together, these events would tend to have offsetting effects on the market. Thus, projections based on less optimistic assumptions about the growth of nuclear power would be consistent with the range of projections for uranium spot-market prices and supply developed in this analysis.

The enrichment services market, with current excess production capacity, is less likely to be subjected to the price volatility that has recently been seen in the $\mathrm{U}_{3} \mathrm{O}_{8}$ market. Enrichment (SWU) derived from U.S. and Russian surplus defense inventories will largely be controlled by USEC, a producer of enrichment services. USEC is expected to act in an economically rational manner that will not disrupt pricing in a way that would affect its own business, selling through long-term contracts rather than on the spot market. USEC also could use the SWU it receives to optimize enrichment capacity, including closing one of its aging gaseous diffusion enrichment plants. The closure of existing enrichment capacity, however, is not likely until privatization of the company takes place and sizable inventories of LEU are accumulated to mitigate possible disruptions in future deliveries of LEU derived from Russian HEU. 
With the acquisition of U.S. and Russian surplus defense inventories, USEC would have access to competitively priced natural uranium feed and economical enrichment capacity to position itself as a marketer of EUP. For the same reasons, Russia could also become a major supplier of EUP. Restrictions on trade, however, limit the penetration of Russian-origin uranium in the Western market. Although it accounts for a relatively small share of existing contract volume, EUP could gain appreciable market share as nuclear power generating companies look for more flexible or less costly ways of managing fuel procurement.

Without commercialization of U.S. and Russian surplus defense inventories, increases in price would be required to induce uranium producers with higher marginal costs of production to enter the market to meet projected demand. The penetration of surplus defense inventories into the marketplace is therefore expected to provide nuclear power generating companies with a benefit of lower uranium procurement costs. Historical data over the past 15 years show a strong correlation between movements in contract and spot-market prices. Thus, the incremental change that would take place for the price of all uranium delivered in a given year can be estimated from projections of spot-market price. Using this methodology, EIA estimates the potential cumulative savings in uranium procurement costs between 1997 and 2010 to be between $\$ 2.9$ and $\$ 3.3$ billion in 1996 dollars. The projected savings would be one consequence of arms reduction agreements between the United States and Russia and other national policies, enabling nuclear materials formerly held for defense purposes to be made available for civilian use. The estimate of potential cumulative savings is considered the most likely from a broad range projected between $\$ 2.1$ billion and $\$ 5.3$ billion dollars in 1996 dollars. Savings in the higher end of the range would be realized if the development of known low-cost reserves is restricted through government policy. On the other hand, the savings could be less than the most likely estimate if new low-cost reserves are discovered and put into production during the forecast period.

The total effect of commercializing U.S. and Russian surplus defense inventories on nuclear power generating companies' fuel costs would also depend on the behavior of the enrichment services market. (Because conversion services make up about 5 percent of the cost of fuel reloaded into a core of a typical light-water reactor, changes in the price of conversion services due to the availability of $\mathrm{UF}_{6}$ from surplus defense inventories would have only a marginal effect on total fuel costs.) Under the current condition of worldwide enrichment overcapacity, USEC is expected to sell the SWU it receives as U.S. Executive Agent for the Russian HEU Agreement in a market neutral manner. It is assumed that most of the potential effect of commercializing surplus defense inventories on fuel procurement costs could be measured by changes in the price of uranium. Should USEC elect to close one of its enrichment plants, the price of SWU could rise as considerable excess capacity is eliminated. However, any rise in SWU price is anticipated to be restrained by the magnitude of lower cost enrichment capacity that would remain in the world. Thus, a possible increase in the cost of enrichment services is expected only to partially offset the impact of lower uranium price on reducing total fuel procurement costs.

\section{Uncertainties}

Market projections are subject to considerable uncertainty. As with other commodities, the uranium and other nuclear fuel cycle markets are affected by demand and supply relationships. Unlike many other markets, however, the trading of uranium has been significantly restricted by government policies. Trade restrictions have been implemented in the United States and European Union in part to support domestic industries or to ensure a diversity of supply for civilian nuclear power programs. For the same reasons, deliveries of uranium derived from surplus defense inventories are restricted by the USEC Privatization Act. It is not certain, however, whether existing restrictions on the sale of commercial supplies of uranium, such as specified by the Suspension Agreement with Russia, will be extended beyond their current statutory limits.

On the demand side, the economics of nuclear power generation could delay the construction of new plants or force the retirement of existing plants. Political and economic factors that would affect future operable nuclear generating capacity, especially related to the restructuring of the electric power industry in the United States and other countries, and the recent financial crisis in the Far East, are not fully understood at this time. A decline in operable generating capacity would result in a decline in demand for nuclear fuel. Assuming that surplus defense inventories will be made available to the market under current plans, less uranium production would be required, and prices would decline. In addition, the extent to which MOX fuel and new enrichment technologies, such as Atomic Vapor Laser Isotope Separation (AVLIS), are utilized would also affect the demand for uranium and enrichment services. 
A key uncertainty on the demand side is the anticipated early retirements of nuclear power plants. For the analysis developed in this report, only 8 of the 110 nuclear power reactors operating in the United States as of December 31, 1996, were assumed to be retired before their license expiration dates. By 2005, early retirements are projected to decrease net generating capacity in the United States by about 5 percent. This assessment of operable capacity in the United States is relatively optimistic when compared with other more recent projections. For example, EIA assumed that 24 reactors would be subject to early retirement in the reference case presented in the Annual Energy Outlook 1998. ${ }^{203}$ The projected increase in early retirements was based on utility announcements and an analysis of operating costs and other factors.

Uncertainties about quantities of excess commercial inventories and the timing by which new uranium mines would receive operating licenses historically have complicated assessments of uranium supply. The plans to make available U.S. and Russian surplus defense inventories have superimposed additional uncertainties on the uranium market. Unanticipated events could ultimately change the longer term supply and demand relationships presented in this report. Moreover, because of the variety of uncertainties, the uranium market is likely to experience short-term volatility. Volatility would produce perturbations in spot-market price over relatively short periods that would not be apparent in the projections developed for this analysis. Short-term perturbations in the spot-market price present a challenge to the nuclear industry-long-term decisions are often based on short-term events.

Because of nonproliferation and other political aspects, the commercialization of U.S. and Russian surplus defense inventories cannot be explained solely in terms of market economics. Political aspects control the timing and quantities of uranium and plutonium that may ultimately be made available for the production of commercial nuclear fuel. Thus, the commercialization programs could be affected by changes in political leadership, internal policies, or diplomatic relations among the nations participating in the programs.

The quantity of uranium derived from Russian HEU that ultimately will become available for use by Western consumers is not known at this time. Because little official information is available on Russian civilian nuclear fuel activities, it is not possible to estimate Russia's capability for supplying uranium without considerable uncertainty. A decline in supply capability could lead Russia to use uranium derived from blending down HEU for its domestic requirements, making a smaller quantity available for consumption by the Western world. In that event, prices on the Western market would be expected to rise above those projected in this analysis.

Finally, larger than anticipated sales of uranium from surplus defense inventories over the next few years could convince Western producers to postpone the development of new mines. New uranium mines are likely to require five to ten years before receiving government approval to operate. For example, development of the McArthur River mine in Canada was approved in May 1997 after the plan had been initially submitted to government authorities in February $1991 .^{204}$ With long lead times required for the startup of new mines, new production might not be available to avert a supply shortfall in the event that schedules are not met for commercializing surplus defense inventories in later years. In response, a sharp price increase could take place. On the other hand, additional unspecified quantities of surplus defense inventories could be released to the commercial market later in the forecast period, displacing relatively higher cost uranium production and causing prices to decline.

${ }^{203}$ Energy Information Administration, Annual Energy Outlook 1998, DOE/EIA-0383(98) (Washington, DC, December 1997), p. 54.

${ }^{204}$ B.W. Jamieson \& S.E. Frost, "The McArthur River Project: High Grade Uranium Mining," in Uranium and Nuclear Energy 1997, Proceedings of the Twenty-Second Annual Symposium of the Uranium Institute (London, September 1997), p. 75. 
Appendix A

Chronology of the Commercialization of Russian Highly

Enriched Uranium 1991-1997 


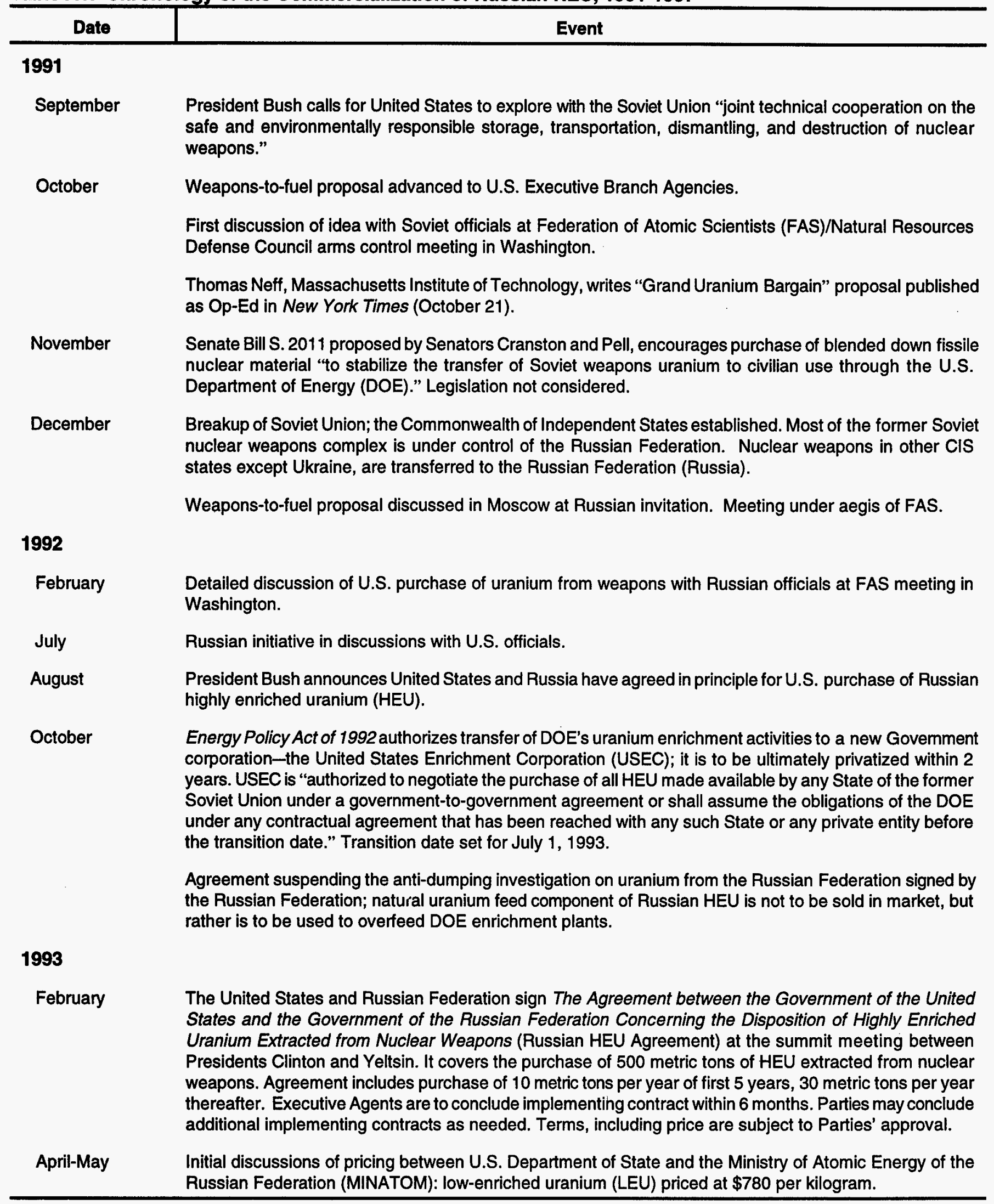




\begin{tabular}{c|cc}
\hline Date & Event \\
\hline 1993 (continued)
\end{tabular}

May

July

September

1994

January

March

April

October

December

1995

February

May
U.S. Department of State and MINATOM sign the basic principles of the HEU contract at ceremonies in Vancouver, Canada. Principles include: partnerships-neither side subsidizes the other, prices and costs are adjusted for inflation and changes in market conditions, Russian gains access to existing U.S. customers, and Russian converted HEU will not be used to undercut Russia in new markets.

Draft implementation contract is signed by DOE and MINATOM. Contains all essential terms of the final contract and it calls for payment for uranium feed component only "as used or sold" by the United States.

USEC takes over the uranium enrichment business of the DOE.

Memorandum of Understanding is signed between the United States and Russian Governments concerning arrangements to ensure that purchased LEU is derived from HEU from nuclear weapons dismantled in Russia (the so-called transparency issue).

Trilateral Agreement signed by the Presidents of the United States, Russia, and Ukraine at the Presidential Summit in Moscow. Ukraine agrees to dismantle nuclear weapons and send the nuclear materials to Russia for deconversion in return for supply of commercial nuclear fuel.

HEU implementation contract for the Russian HEU Agreement signed by USEC and Techsnabexport (TENEX) at the summit meeting between Presidents Clinton and Yeltsin in Moscow. Contract essentially unchanged from May version. Addendum transfers contract from DOE to USEC. Initial deliveries expected in 5 months.

Amendment to the Suspension Agreement with the Russian Federation signed. It sets "matched sales" quotas, whereby imports must be matched with U.S.-origin uranium.

Transparency agreement signed, as required under HEU deal.

At U.S. Government's direction, USEC advances first $\$ 15$ million of $\$ 60$ million against future LEU from HEU deliveries in connection with Ukraine trilateral agreement.

No agreement on prices at the scheduled annual review between TENEX and USEC.

U.S.-Canadian consultations following Canadian challenge under the North American Free Trade Agreement. U.S. agrees to limit amount of Russian uranium that will enter the U.S. market, as stated in amendment to the Russian Suspension Agreement.

USEC seeks DOC action to close enrichment "bypass." Closure would make Russian-origin uranium an export of Russia regardless of whether enrichment took place in another country.

Protocol signed by USEC and TENEX summarizes commercial differences between parties to implementation contract. TENEX proposes to count both $U$ and SWU in LEU against repayment of $\$ 60$ million advance. USEC proposes to pay $\$ 82.10 / \mathrm{SWU}$ for first 10 metric tons $\mathrm{HEU}$, with one-half applied to $\$ 60$ million debt, but to reduce the SWU price to $\$ 68$ for second 10 metric tons HEU (1996 dellvery), and no payment for uranium on first 20 metric tons; uranium to be returned to TENEX.

Exchange of letters between United States and Canada recording agreements.

Senator Pete Domenici introduces legislation, Senate Bill S.755, to allow forward sales in the United States of uranium content of LEU from Russian HEU and to permit Russia to regain title from USEC, ensuring payment for feed component of Russian HEU (proposal was later modified to allow phased-in sales approach with earlier revenue for Russia.) 
Table A1. Chronology of the Commerclallzation of Russian HEU, 1991-1997 (Continued)

\begin{tabular}{c|c}
\hline Date & Event \\
\hline
\end{tabular}

1995 (continued)

June

Protocol signed by USEC and MINATOM summarizes commercial differences between parties to implementation contract. USEC offers to pay for uranium content if it obtains change in U.S. law to permit USEC to sell it in the United States without restriction, as per "Administration proposal supported by USEC." Proposal conflicts with that introduced by Domenici. Parties disagree on repayment of $\$ 60$ million and on basis for setting future prices. MINATOM to receive $\$ 100$ million "advance payment"; USEC receives four months to secure changes in laws and agreements. Implementation of contract-start date reset at FY95 (FY96 to be second year of contract.)

June First shipment of LEU from Russian HEU to United States.

July-August Compromise on legislative approach to HEU and USEC Privatization negotiated between Administration, USEC, and Congress.

September Senate passes revised S.755, setting terms to improve HEU deal.

November $\quad$ USEC makes first shipment of Russian LEU to a customer.

1996

April

USEC Privatization Act signed, setting maximum annual sale in the market of uranium feed from Russian $\mathrm{HEU}$ and requiring the President to monitor and report on USEC's actions annually with regard to the effect Russian LEU deliveries have on U.S. uranium, conversion and enrichment industries. The USECMINATOM implementing contract must be amended to state that the Russians have the right to ask that feed be returned immediately for sale under the provisions of the Act or be auctioned by USEC with proceeds to be paid to the Russians.

August $\quad$ USEC turns down Russians' offer to increase the level of deliveries of LEU from HEU to 18 MT in 1997 from the 12 MT now being delivered. This action prompts Senator Domenici to write a letter to Deputy Energy Secretary Charles Curtis, raising question of whether USEC is more interested in maximizing profits than in meeting national security goals and suggesting that USEC be removed as executive agent.

September USEC and TENEX begin first round of negotiations on price to be paid for 1997 and 1998 deliveries of LEU from Russian HEU. Russian HEU Agreement amended to eliminate USEC's requirement to pay for natural uranium component of LEU purchased from Russia.

October Russian Suspension Agreement further amended to close enrichment bypass in exchange for allowing Russia to sell SWU to the United States in quantities unused in previous years' quotas.

November Russians bring the Siberian Chemical Enterprise complex online to increase HEU blending capacity. Amendment to Russian HEU Agreement is finalized, establishing contract obligations for the next five years. Deliveries of Russian HEU are to start at 18 metric tons in 1997 and rise to 24 metric tons in 1998 and 30 metric tons in 1999 through 2001.

December USEC transfers to DOE the equivalent of about 14 million pounds of $\mathrm{U}_{3} \mathrm{O}_{8}$ representing the natural uranium component of Russian LEU derived from the blending down of 18 metric tons of HEU it purchased during 1995 and 1996 under the Russian HEU Agreement. This transfer was directed by the USEC Privatization Act.

1997

April Representatives from Pleiades meet with U.S. State Department officials to discuss Pleiades' interest in purchasing the natural uranium component of LEU derived from Russian HEU.

July President Clinton approves the initiation of USEC privatization. 
Date

Event

1997 (continued)

August

Cameco Corp., Cogema, and Nukem Inc. sign an agreement in principal with MINATOM for the purchase of the natural uranium component of LEU derived from Russian HEU. Cameco and Cogema each will have access to 45 percent of an unspecified quantity to be made available by MINATOM; Nukem's share will be 10 percent.

October

DOC proposes procedures to administer and enforce the U.S. quotas for the natural uranium component, as provided by the USEC Privatization Act.

December

Cameco Corp., Cogema, and Nukem, Inc. announce that discussions with MINATOM concerning the purchase of the natural uranium component of LEU derived from Russian HEU have been suspended.

USEC reports purchases from 1995 through 1997 pursuant to the Russian HEU Agreement have totaled 1,038 metric tons of LEU produced from blending down 36 metric tons of HEU taken from Russian surplus nuclear weapons.

Sources: Neff, Thomas, Speech presented at the Nuclear Energy Institute's Nuclear Fuel Supply Forum (Washington, DC, January 28, 1997); United States Enrichment Corporation, "Chronology of the Megatons to Megawatts Contract (as of January 27, 1997)" (Bethesda, MD, January 1997) and "Megatons to Megawatts Program Progress Status" (Bethesda, MD, December 1997); The $U_{x}$ Consulting Company, LLC, Analysis of World Nuclear Fuel Inventories (Marietta, GA, April 1997), Appendix A; updated by Energy Information Administration, Office of Coal, Nuclear, Electric and Alternate Fuels. 
Appendix B

Key Milestones in the Disposition of U.S. Government Surplus Highly Enriched Uranium, CommercialGrade Uranium, and Plutonium, 1992-1997 
Table B1. Key Milestones in the Disposition of U.S. Government Surplus Highly Enriched Uranium (HEU), Commercial-Grade Uranium, and Plutonium, 1992-1997

\begin{tabular}{|c|c|c|}
\hline Date & HEU and Commercial-Grade Uranium & Plutonium \\
\hline 1992 & U.S. Government ends all HEU production. & \\
\hline April & & $\begin{array}{l}\text { U.S. Government announces intent to end } \\
\text { reprocessing of spent fuel from plutonium- } \\
\text { production reactors. }\end{array}$ \\
\hline May & & $\begin{array}{l}\text { President Bush's National Security Advisor } \\
\text { commissions the U.S. National Academy of } \\
\text { Sciences (NAS) to study the disposition of } \\
\text { surplus weapons plutonium. }\end{array}$ \\
\hline October & $\begin{array}{l}\text { Energy Policy Act of } 1992 \text { (EPACT) signed into } \\
\text { law. It directs the Secretary of Energy to } \\
\text { determine the availability of uranium materials, } \\
\text { including HEU, for conversion to commercial } \\
\text { use and to provide plans for such conversion. } \\
\text { EPACT authorizes transfer of DOE's uranium } \\
\text { enrichment activities to a new government } \\
\text { corporation-the United States Enrichment } \\
\text { Corporation (USEC). }\end{array}$ & \\
\hline \multicolumn{3}{|l|}{1993} \\
\hline \multirow{2}{*}{$\begin{array}{l}\text { June } \\
\text { September }\end{array}$} & \multicolumn{2}{|c|}{$\begin{array}{l}\text { U.S. Department of Energy (DOE) announces "up to approximately } 50 \text { metric tons of plutonium" } \\
\text { and " } 25 \text { to } 100 \text { metric tons" of HEU could be made available for civil use. }\end{array}$} \\
\hline & \multicolumn{2}{|c|}{ President Clinton announces Nonproliferation and Export Control Policy. } \\
\hline \multicolumn{3}{|l|}{1994} \\
\hline \multirow[t]{2}{*}{ January } & & $\begin{array}{l}\text { NAS Committee on International Security and } \\
\text { Arms Control issues Management and } \\
\text { Disposition of Excess Weapons Plutonium. It } \\
\text { proposes disposition of surplus weapons-grade } \\
\text { plutonium by (1) irradiation as mixed-oxide fuel } \\
\text { (MOX) in commercial nuclear power plants } \\
\text { ("reactor option"), and (2) immobilization and } \\
\text { storage ("immobilization option"). }\end{array}$ \\
\hline & \multicolumn{2}{|c|}{$\begin{array}{l}\text { Secretary of Energy initiates Fissile Materials Disposition Project to develop and implement plans } \\
\text { to dispose of weapons-usable fissile materials. }\end{array}$} \\
\hline June & \multicolumn{2}{|c|}{$\begin{array}{l}\text { DOE announces its intent to prepare "Storage and Disposition of Weapons-Usable Fissile } \\
\text { Materials Programmatic Environmental Impact Statement" (S\&D PEIS); it considers the storage } \\
\text { and disposition of both HEU and plutonium. }\end{array}$} \\
\hline August-October & \multicolumn{2}{|c|}{ DOE holds public workshops to gather input regarding the proposed PEIS. } \\
\hline September & \multicolumn{2}{|c|}{$\begin{array}{l}\text { United States submits HEU and plutonium under International Atomic Energy Agency Safeguards; } \\
\text { it becomes first nuclear weapons state to submit surplus defense materials for verification. }\end{array}$} \\
\hline November & $\begin{array}{l}\text { DOE and the U.S. Enrichment Corporation } \\
\text { (USEC) sign a Memorandum of Understanding, } \\
\text { whereby DOE will transfer at no cost } 13 \text { metric } \\
\text { tons of HEU to USEC. }\end{array}$ & \\
\hline
\end{tabular}


Table B1. Key Milestones in the Disposition of U.S. Government Surplus Highly Enriched Uranium (HEU), Commercial-Grade Uranlum, and Plutonium, 1992-1997 (continued)

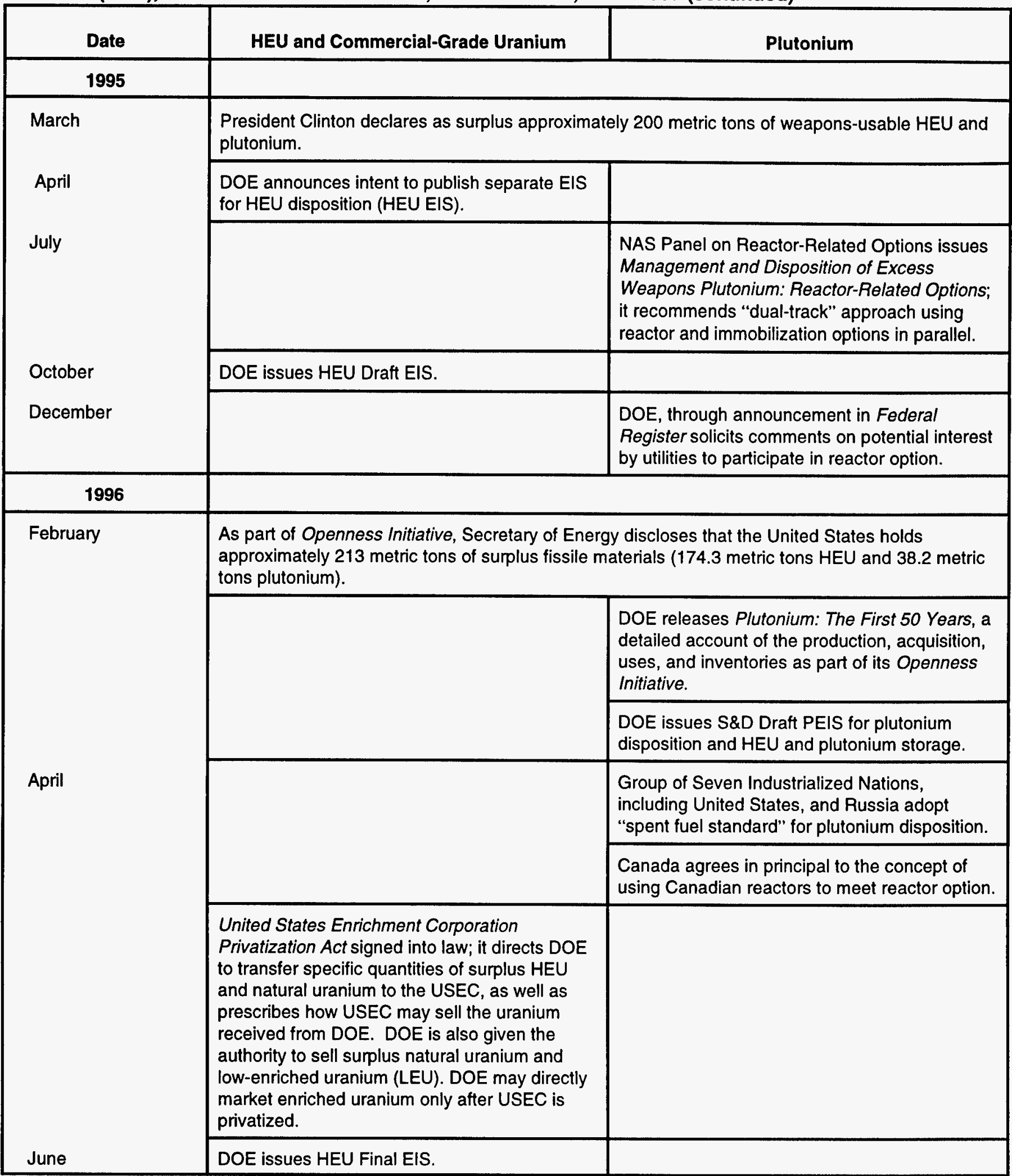


Table B1. Key Milestones in the Disposition of U.S. Government Surplus Highly Enriched Uranium (HEU), Commercial-Grade Uranium, and Plutonium, 1992-1997 (continued)

\begin{tabular}{|c|c|c|}
\hline Date & HEU and Commercial-Grade Uranium & Plutonium \\
\hline \multicolumn{3}{|c|}{1996 (continued) } \\
\hline \multirow[t]{2}{*}{ July } & DOE issues Record of Decision for HEU EIS. & \\
\hline & $\begin{array}{l}\text { DOE proposes to sell surplus inventories of } \\
\text { natural uranium and LEU. }\end{array}$ & \\
\hline September & DOE issues HEU Disposition Plan. & $\begin{array}{l}\text { Interim report of the U.S.-Russia Independent } \\
\text { Scientific Commission recommends that the } \\
\text { United States and Russia move quickly to } \\
\text { implement both immobilization and reactor } \\
\text { options for disposition. }\end{array}$ \\
\hline October & $\begin{array}{l}\text { DOE issues final Environmental Assessment } \\
\text { DOE Surplus Natural and Low Enriched } \\
\text { Uranium (EA). The EA proposes to commence } \\
\text { selling as soon as possible natural uranium and } \\
\text { LEU from DOE inventories and the natural feed } \\
\text { component of Russian LEU transferred from } \\
\text { USEC. }\end{array}$ & \\
\hline \multirow[t]{2}{*}{ December } & & $\begin{array}{l}\text { Clinton Administration announces dual-track } \\
\text { approach for disposition as "preferred } \\
\text { alternative." }\end{array}$ \\
\hline & & DOE issues S\&D Final PEIS. \\
\hline \multicolumn{3}{|l|}{1997} \\
\hline January & $\begin{array}{l}\text { Memorandum of Understanding signed } \\
\text { between DOE and Tennessee Valley Authority } \\
\text { (TVA) for the demonstration and utilization by } \\
\text { TVA of LEU from "off-spec" U.S. HEU. }\end{array}$ & DOE issues Record of Decision for S\&D PEIS. \\
\hline March & $\begin{array}{l}\text { DOE issues Secretary's Determination; DOE's } \\
\text { proposed sale during Fiscal Year } 1997 \text { of } \\
\text { surplus natural uranium and LEU "will not have } \\
\text { an adverse material impact on the domestic } \\
\text { uranium mining, conversion, or enrichment } \\
\text { industry." }\end{array}$ & \\
\hline May & & $\begin{array}{l}\text { DOE publishes Program Acquisition Strategy } \\
\text { for Obtaining Mixed Oxide Fuel Fabrication and } \\
\text { Reactor Irradiation Services (PAS). }\end{array}$ \\
\hline September & $\begin{array}{l}\text { DOE receives qualified bids for natural uranium } \\
\text { offered for sale }\end{array}$ & \\
\hline
\end{tabular}

Sources: Holdren, J., Ahearne, J., Garwin, R., Panofsky, W., Taylor, J., and Bunn, M., "Excess Weapons Plutonium: How to Reduce a Clear and Present Danger," in Arms Control Today (November/December 1996), pp. 3-9; Public Law 104-134, Balanced Budget Down Payment Act, Subchapter A-USEC Privatization Act (April 26, 1996); U.S. Department of Energy, Plutonium: The First 50 Years (Washington, DC, February 1996), 82 p.; U.S. Department of Energy, Office of Fissile Materials Disposition, documents announcements related to programs for the disposition and storage of weapons-usable fissile materials (highly enriched uranium and plutonium); Office of Nuclear Energy, Science and Technology and Office of the Secretary, documents and announcements related to plans to sell surplus natural uranium and low-enriched uranium. 
Appendix C

Principal Documents

Prepared by the U.S.

Department of Energy

for the Storage and/or

Disposition of U.S.

Government Surplus

Highly Enriched

Uranium, Plutonium,

Natural Uranium, and

Low-Enriched Uranium

in Accordance with the

National Environmental

Policy Act, June

1994-May 1997 
Table C1. Principal Documents Prepared by the U.S. Department of Energy for the Storage and/or Disposition of U.S. Government Surplus Highly Enriched Uranium (HEU), Plutonium, Natural Uranium, and Low-Enriched Uranium (LEU) in Accordance with the National Environmental Policy Act, June 1994-May 1997

\begin{tabular}{|c|c|c|}
\hline \multicolumn{2}{|c|}{$\begin{array}{l}\text { Storage and Disposition of Weapons-Usable Fissile Materials } \\
\text { (Office of Fissile Materials Disposition) }\end{array}$} & $\begin{array}{l}\text { Sale of Natural Uranium and LEU } \\
\text { (Office of Nuclear Energy, } \\
\text { Sclence and Technology) }\end{array}$ \\
\hline HEU Disposition & $\begin{array}{l}\text { Plutonium Disposition, HEU and } \\
\text { Plutonlum Storage }\end{array}$ & \\
\hline 1995 & 1995 & \\
\hline $\begin{array}{l}\text { April. Notice of Intent to prepare a separate } \\
\text { EIS for HEU disposition published in the } \\
\text { Federal Register (April 5) } \\
\text { June. Implementation Plan for HEU EIS } \\
\text { issued (DOE/EIS-0240-IP) (note) } \\
\text { October. HEU Draft EIS issued (DOE/EIS- } \\
\text { O240-D) } \\
\text { October. Notices of Avallabllity of the HEU } \\
\text { Draft EIS published separately by both DOE } \\
\text { (October 26) and EPA (October } 27 \text { ) in the } \\
\text { Federal Register, public comment period } \\
\text { open to December 11, } 1995 \\
\text { November. DOE, responding to public } \\
\text { requests, publishes a Notice in the Federal } \\
\text { Register (November 24) extending the } \\
\text { comment perlod for HEU Draft EIS to January } \\
12,1996\end{array}$ & $\begin{array}{l}\text { March. Implementation Plan for S\&D PEIS } \\
\text { Issued (DOE/EIS-0229-IP) }\end{array}$ & \\
\hline $\begin{array}{l}\text { July. Record of Decision for HEU Final EIS } \\
\text { issued on July } 29, \text { published in the Federal } \\
\text { Register on August } 5,1996\end{array}$ & $\begin{array}{l}\text { March. Notices of Avallability of the S\&D } \\
\text { Draft PEIS published separately by both DOE } \\
\text { and EPA in the Federal Register (March 8); } \\
\text { public comment period open to May } 7,1996 \\
\text { May. DOE, responding to public requests, } \\
\text { publishes a Notice in the Federal Register } \\
\text { (May 13) extending the comment period for } \\
\text { S\&D Draft PEIS to June 7, } 1996\end{array}$ & $\begin{array}{l}\text { August. Uranium Draft EA issued (DOE/EA- } \\
\text { 1172) } \\
\text { August. Notice of Avallability of the Uranium } \\
\text { Draft EA published in the Federal Register } \\
\text { (August 12); public comment perlod open to } \\
\text { September 11, } 1996\end{array}$ \\
\hline
\end{tabular}


Table C1. Principal Documents Prepared by the U.S. Department of Energy for the Storage and/or Disposition of U.S. Government Surplus Highly Enriched Uranium (HEU), Plutonlum, Natural Uranlum, and Low-Enriched Uranium (LEU) In Accordance with the National Environmental Policy Act, June 1994-May 1997 (continued)

\begin{tabular}{|c|c|c|}
\hline \multicolumn{2}{|c|}{$\begin{array}{l}\text { Storage and Disposition of Weapons-Usable Fissile Materials } \\
\text { (Office of Fissile Materials Disposition) }\end{array}$} & $\begin{array}{c}\text { Sale of Natural Uranium and LEU } \\
\text { (Office of Nuclear Energy, } \\
\text { Sclence and Technology) }\end{array}$ \\
\hline & 1996 & 1996 \\
\hline & & \\
\hline & 1997 & \\
\hline & $\begin{array}{l}\text { January. Record of Declsion for S\&D Final } \\
\text { PEIS issued on January 14, published in the } \\
\text { Federal Register on January 21, } 1997 \\
\text { May. Notice of Intent to prepare Surplus } \\
\text { Plutonlum Disposition EIS published in the } \\
\text { Federal Register (May 22) }\end{array}$ & \\
\hline
\end{tabular}

Note: DOE code In parenthesis, such as (DOE/EIS-0240-IP), refers to published document.

Explanation: S\&D PEIS-"Storage and Disposition of Weapons-Usable Fissile Materials Programmatic Environmental Impact Statement;" HEU EIS"Disposition of Surplus Highly Enriched Uranium Environmental Impact Statement;" Uranium EA-"Environmental Assessment DOE Sale of Surplus Natural and Low Enriched Uranium;" Uranium FONSI-"DOE Sale of Surplus Natural and Low Enriched Uranlum Finding of No Significant Impact."

Sources: HEU disposition-U.S. Department of Energy, "Record of Decision for the Disposition of Surplus Highly Enriched Uranium Final Environmental Impact Statement," in Federal Register, Vol. 61 (August 5, 1996), pp. 40616-40619; Storage and disposition-U.S. Department of Energy, "Record of Decision for the Storage and Disposition of Weapons-Usable Fissile Materials Final Programmatic Environmental Impact Statement," in Federal Register, Vol. 62 (January 21, 1997), pp. 3014-3030; LEU and natural uranium-U.S. Department of Energy, "Sale of Surplus Natural and Low Enriched Uranium Finding of No Signlficant Impact," in Federal Register, Vol. 61 (October 22, 1996), pp. 54780-54781. 
Appendix D

Description of the Uranium Market Model 


\section{Appendix D}

\section{Description of the Uranium Market Model}

\section{Overview}

Most of the uranium projections in this report were generated by the Uranium Market Module (UMM). UMM is a microeconomic model in which uranium supplied by the mining and milling industry is used to meet the demand for uranium by electric utilities with nuclear power plants. Uranium is measured on a $\mathrm{U}_{3} \mathrm{O}_{8}$ concentrate equivalent basis. The input data encompass every major production center and utility in the world. The model provides annual projections for each major uranium production and consumption region in the world. Sixteen regions were used in this study: (1) the United States, (2)Canada, (3) Australia, (4) South Africa, (5) Other Africa, (6) Western Europe, (7) Latin America, (8) the East, (9) Other, (10) Eastern Europe, (11) Russia, (12) Kazakhstan, (13) Uzbekistan, (14) Ukraine, (15) Kyrgyz Republic, and (16) Other Former Soviet Union.

\section{Uranium Demand}

Uranium demand is assumed to equal near-term unfilled requirements on the part of utilities. Unfilled requirements are determined by subtracting current contract commitments at firm (non-spot) prices and inventory drawdown from total reactor requirements plus any assumed inventory buildup. Contract commitments calling for price to equal the future spet prices with no firm floor price are thus included in the calculation of uranium demand. In this way, demands may be placed on the market by uranium producers with such contracts when the spot price falls below the production costs of these producers.

The demand for uranium by electric utilities with nuclear power plants is a key parameter. Annual projections of reactor requirements are from EIA forecasts (see Chapter 3 for domestic forecasts). In the model, individual utility requirements were combined into regional totals. These projections are assumed to be inelastic with respect to uranium prices, separative work unit prices, and tails assays. Scenarios with varying demands can be determined by using alternative inputs for projected reactor requirements.

In addition to reactor requirements, most utilities also maintain a uranium inventory as a contingency against possible disruptions in supply. The desired degree of forward inventory coverage varies by country, due to such factors as national policies, contracting approaches, and regulatory treatment of inventory costs. These variations are incorporated in the model. Inventory demand is a function of future reactor requirements and future uranium prices which change annually. This demand is elastic with respect to the spot price and, in line with market behavior, decreases as the price falls and increases as the price rises.

Contract commitments, between both producers and electric utilities and between utilities and enrichment suppliers, are taken into account exogenously. Commitments between producers and electric utilities are considered in two ways. The first is an estimate of the overcommitments by utilities to purchase uranium in excess of their annual reactor requirements. The second represents producer-utility contracts by specifying the commitments made by producers to deliver uranium from a specific production center to a particular utility. Contracts between utilities and enrichment suppliers can also lead to overcommitments in terms of the utility buying uranium for committed deliveries to enrichment plants that exceed the utility's reactor requirements.

\section{Uranium Supply}

Uranium supply is represented by an annual short-run supply curve consisting of increments of potential production and the supply of excess inventories which are assumed to be available at different market prices. Production centers are defined as mine-mill combinations, if there is conventional production, and as processing facilities for nonconventional production. Also included are producers in Western countries, Eastern Europe, the Former Soviet Union, and China that are potential net 
exporters. In general, production centers come on line, produce uranium, and deplete their reserves depending on a number of geological, engineering, market, and political conditions. Producers that are able to produce and sell uranium most cheaply generally occupy the lower portions of the supply curve. Production costs are estimated exogenously, taking the following into account: the size of the reserves; annual production capacity; ore grade; type of production; capital, labor, and other costs; and taxes and royalty requirements. A fair market rate of return is also assumed. Government subsidies, variations in exchange rates, floor prices, supply disruptions, or other factors may affect the shape of the supply curve each year.

Some excess utility inventories are also treated as sources of potential supply that may be drawn down or sold in the secondary market. The size of these yearly drawdowns and sales depends on the utility's desired level of contingency stocks, spot-market prices, and the utility's general propensity to draw down its stocks or to sell uranium in the secondary market. Thus, each utility's inventory level varies annually depending on its projected reactor requirements, its contract commitments with producers and enrichment suppliers, the trend in market prices, its own inventory planning strategy, and the sales of excess inventories held by suppliers and governments.

\section{Market-Clearing Conditions}

Equilibrium is achieved in the forecasts when the supply of uranium meets the demand for uranium. Supply comes from production centers; utilities' inventories, which may already be at levels sufficient to satisfy inventory demand; excess inventories held by suppliers and governments; and utilities' excess inventories which are drawn down or are sold in the secondary market. ${ }^{205}$ Demand consists of utility reactor requirements, contingency inventory demand, and any additional market demand resulting from contract over commitments with either producers or enrichment facilities.

The market projections in any given year are determined by activities in previous years, such as market prices and decisions to defer production of reserves. Projected demand levels are affected by reactor requirements in future years. Unanticipated changes in future demand may be introduced exogenously so that market activities in any forecast year may be constrained by actions taken in previous years.

Under free-market conditions with a single world market, utilities may draw down their inventories either for their own use or for sale in the secondary market; production is allocated to satisfy contract commitments; and remaining demand is met by producers with uncommitted reserves and by other suppliers with holdings of uranium. The intersection of this supply curve with the unfilled demand identifies the particular production and other supply increments that are sold in the market and defines the equilibrium spot-market price for that year. These sales, together with those from contract commitments, are tabulated to give projections of production in the United States and in other regions. ${ }^{206}$ The equilibrium spot-market price and the 1year lagged spot-market price are used to compute a projected spot-market price. Projected prices for new contracts are estimated as a function of the projected spot-market price. The net imports of a country are calculated from its utilities' reactor requirements, contingency inventory demand, contract commitments, inventory use, and its producers' sales.

\footnotetext{
${ }^{205}$ Loans of uranium among the various suppliers and users are not modeled as such. Borrowing and lending activities do not alter the total inventories of uranium, but they do delay the purchase of newly produced uranium. This effect can be modeled by assuming that the inventories of uranium that are not held by utilities or producers remain constant at their current level.

${ }^{206}$ In projecting production in the United States and other regions, the modeling system considers only those contract commitments that are tied to specific production centers at firm prices. For this reason, the model in some instances projects production at lower levels than contract commitments.
} 
Appendix E

U.S. Customary Units

of Measurement, International System of Units (SI), and Selected

Tables and Figures in SI Metric Units 


\section{Appendix E}

\section{U.S. Customary Units of Measurement, International System of Units (SI), and Selected Tables and Figures in SI Metric Units}

Standard factors for interconversion between U.S. customary units and the International System of Units (SI) are shown in the table below. These factors are provided as a coherent and consistent set of units for the convenience of the reader in making conversions between U.S. and metric units of measure for data published in this report. Conversion factors are provided only for the U.S. units of measurement quoted in this report.

Conversion Factors for U.S. Customary Units and SI Metric Units of Measurement

To convert from:

pounds $\mathrm{U}_{3} \mathrm{O}_{8}$

million pounds $\mathrm{U}_{3} \mathrm{O}_{8}$

\$per pound $\mathrm{U}_{3} \mathrm{O}_{8}$
To:

kilogram U

thousand metric tons $U$

\$ per kilogram U
Multiply by:

0.384647

0.384647

2.599786 
Table E1. U.S. Restrlctions on Selling the Uranium Feed Component of Low-Enriched Uranlum (LEU) Produced from Blending Down Russian HIghly Enriched Uranlum (HEU) After January 1, 1997

\begin{tabular}{|c|c|c|c|c|}
\hline Delivery Year & $\begin{array}{c}\mathrm{HEU}^{\mathrm{a}} \\
\text { (metric tons) }\end{array}$ & $\begin{array}{c}\text { Feed Contained } \\
\text { in LEU } \\
\text { Produced from HEU } \\
\text { (thousand metric tons } U \text { ) }\end{array}$ & $\begin{array}{c}\text { Direct Quota } \\
\text { to U.S. End Users } \\
\text { (thousand metric tons U) }\end{array}$ & $\begin{array}{c}\text { Russian } \\
\text { Matching Schedule } \\
\text { (thousand metric tons U) }\end{array}$ \\
\hline $1997 \ldots \ldots \ldots$ & 18 & 5.5 & -. & 1.0 \\
\hline $1998 \ldots \ldots \ldots \ldots \ldots$ & 24 & 7.3 & 0.8 & 1.4 \\
\hline $1999 \ldots \ldots \ldots \ldots \ldots$ & 30 & 9.2 & 1.5 & 1.6 \\
\hline $2000 \ldots$ & 30 & 9.2 & 2.3 & 1.6 \\
\hline 2001 & 30 & 9.2 & 3.1 & 1.6 \\
\hline $2002 \ldots$ & 30 & 9.2 & 3.8 & 1.9 \\
\hline 2003 & 30 & 9.2 & 4.6 & 1.7 \\
\hline 2004 & 30 & 9.2 & 5.4 & -- \\
\hline 2005 & 30 & 9.2 & 6.2 & -- \\
\hline $2006 \ldots \ldots \ldots \ldots \ldots$ & 30 & 9.2 & 6.5 & -- \\
\hline $2007 \ldots \ldots$ & 30 & 9.2 & 6.9 & -- \\
\hline $2008 \ldots \ldots \ldots \ldots \ldots$ & 30 & 9.2 & 7.3 & -- \\
\hline 2009 and beyond $\ldots \ldots \ldots$ & 30 & 9.2 & 7.7 & -- \\
\hline
\end{tabular}

a Likely capacity for blending Russian HEU down to low-enriched uranium; the quantity for 1997-2001 pursuant to an agreement between the U.S. Enrichment Corporation and Techsnabexport, November 1996. For 2002 and later years, it is assumed that 30 metric tons of $\mathrm{HEU}$ will be blended down to LEU.

${ }^{\mathrm{b}}$ The equivalent $\mathrm{U}_{3} \mathrm{O}_{8}$ contained in low-enriched uranium (LEU) produced from blending HEU having a ${ }^{235} \mathrm{U}$ content of 90 percent with slightly enriched uranium having a ${ }^{235} \mathrm{U}$ content of 1.5 percent. For example, the LEU produced from 18 metric tons of HEU would contain the equivalent of 5.5 metric tons $U$ in the following combination: 4.0 metric tons $U$ in the HEU feedstock and 1.6 metric tons $U$ in the slightly enriched uranium blendstock.

'Pursuant to the USEC Privatization Act (April 26, 1996), Section 3112(b).

${ }^{d}$ The Amendment to the Suspension Agreement with the Russian Federation (March 11, 1994) provides for a schedule whereby Russia can sell uranium at specified quantities to U.S. end users as long as the sales are matched with newly produced U.S.origin uranium.

Sources: Quota and schedule-See footnotes $c$ and d; Uranium feed contained in LEU-Energy Resources International, Inc., “1997 Nuclear Fuel Cycle Supply and Price Report” (Washington, DC, May 1997), Table 4-18. 
Table E2. Equivalent Natural Uranium Feed and SWU Components of Low-Enriched Uranium (LEU) Derived from U.S. Highly Enriched Uranlum (HEU) Based on the U.S. Department of Energy's Plans to Transfer Surplus HEU to the Unlted States Enrichment Corporation (USEC) and the Tennessee Valley Authorlty (TVA)

\begin{tabular}{|c|c|c|c|c|c|c|}
\hline \multirow{2}{*}{$\begin{array}{c}\text { HEU } \\
\text { Quantity } \\
\text { (metric tons) }\end{array}$} & \multirow{2}{*}{$\begin{array}{c}\text { Average }{ }^{235} \mathbf{U} \\
\text { Assay } \\
\text { (percent) }\end{array}$} & \multicolumn{2}{|c|}{$\begin{array}{l}\text { Uranium Feed Component } \\
\text { (thousand metric tons U) }\end{array}$} & \multicolumn{2}{|c|}{$\begin{array}{l}\text { Enrichment Component } \\
\text { (million SWU) }\end{array}$} & \multirow[b]{2}{*}{$\begin{array}{l}\text { Recipient and } \\
\text { Time of Transfer }\end{array}$} \\
\hline & & $\mathrm{HEU}^{\mathrm{b}}$ & $\begin{array}{l}\text { Blended LEU } \\
\text { Product }{ }^{c}\end{array}$ & $\mathrm{HEU}^{\mathrm{b}}$ & $\begin{array}{l}\text { Blended LEU } \\
\text { Product }^{\mathrm{c}}\end{array}$ & \\
\hline 13 & 75.7 & 2.4 & 3.7 & 2.1 & 2.3 & USEC: $1993^{d}$ \\
\hline 50 & 41.3 & 5.0 & 5.4 & 4.2 & 3.4 & USEC: $1998-2003$ \\
\hline $38^{\theta}$ & 66.0 & 6.0 & 6.8 & 5.2 & 4.3 & TVA: $2003-2015^{t}$ \\
\hline
\end{tabular}

\footnotetext{
${ }^{a}$ The separative work units (SWU) of enrichment required to produce equivalent LEU, assuming enrichment tails at 0.30 percent
} ${ }^{235} \mathrm{U}$.

${ }^{\mathrm{b}}$ The equivalent $\mathrm{U}_{3} \mathrm{O}_{8}$ or SWU contained in HEU with the following average ${ }^{235} \mathrm{U}$ assays: 13 metric tons, 75.7 percent; 50 metric tons, 41.3 percent; 38 metric tons, 66.0 percent.

'The equivalent $\mathrm{U}_{3} \mathrm{O}_{8}$ or SWU contained in LEU bended down from HEU. Different blendstock assays are assumed for each HEU class as follows: 13 metric tons HEU-LEU (2.0 percent ${ }^{235} \mathrm{U}$ ), 50 metric tons HEU-natural uranium (0.71 percent $\left.{ }^{235} \mathrm{U}\right), 38$ metric tons HEU-slightly enriched uranium (1.25 percent ${ }^{235} \mathrm{U}$ ) and natural uranium (0.71 percent $\left.{ }^{235} \mathrm{U}\right)$.

${ }^{d} U S E C$ expects to complete the blending of highly enriched uranium hexafluoride $\left(U F_{6}\right)$ to low-enriched $U F_{6}$ by 1998.

${ }^{\theta}$ The actual amount may be less depending on the final characterization of the HEU.

'TVA expects to use a small amount of LEU derived from HEU as a lead fuel assembly demonstration scheduled for 1999.

Source: R. Schmidt, personal communication, (DOE HEU Disposition Program Office, Oak Ridge, TN, March 3, 1998). 

Natural Uranium and Low-Enriched Uranium (LEU), as of October 31, 1997

\begin{tabular}{|c|c|c|c|c|c|}
\hline $\begin{array}{l}\text { Planned } \\
\text { Action }\end{array}$ & $\begin{array}{l}\text { Quantity } \\
\text { (thousand } \\
\text { metric tons } \\
\text { (TMT) U } \\
\text { equivalent) }\end{array}$ & Schedule & $\begin{array}{c}\text { Secretarial } \\
\text { Determination }\end{array}$ & $\begin{array}{c}\text { Transactions } \\
\text { to Date }\end{array}$ & Comments \\
\hline $\begin{array}{l}\text { Sell DOE } \\
\text { Surplus } \\
\text { Natural } \\
\text { Uranlum } \\
(\text { as UF })^{b}\end{array}$ & 7.8 & $\begin{array}{l}\text { Sell all between } 1996 \text { and } 2004 \text { for } \\
\text { domestic of foreign end use after } \\
\text { Secretarial Determination; for FY } 97^{\circ} \\
\text { not to exceed } 0.8 \text { TMTU if all LEU is } \\
\text { sold (see below). Total sales of } \\
\text { natural uranium and LEU cannot } \\
\text { exceed } 1.2 \text { TMTU per year }\end{array}$ & $\begin{array}{l}\text { March } 12,1997 \text {; } \\
\text { sales authorized } \\
\text { for FY97 }\end{array}$ & $\begin{array}{l}\text { In August } 1997, \text { DOE invited } \\
\text { bids for } 0.4 \text { TMTU equivalent } \\
\text { and } 382,781 \mathrm{~kg} U \text { conversion } \\
\text { for delivery by September } 30, \\
1999 . \text { Contracts completed } \\
\text { between DOE and the winning } \\
\text { bidders during October } 1997 .\end{array}$ & $\begin{array}{l}\text { Natural uranium to be sold } \\
\text { as follows: } \\
\text { - Competitive sealed } \\
\text { bids } \\
\text { - Uranlum and } \\
\text { conversion } \\
\text { components offered } \\
\text { separately } \\
\text { - Award to highest } \\
\text { bidder } \\
\text { - If bids not adequate, } \\
\text { some uranium could } \\
\text { be retained for later } \\
\text { sale }\end{array}$ \\
\hline
\end{tabular}

\begin{tabular}{|c|c|c|c|c|c|}
\hline $\begin{array}{l}\text { Sell DOE } \\
\text { Surplus } \\
\text { LEU }\end{array}$ & 0.5 & $\begin{array}{l}\text { Sell all for domestic or foreign end } \\
\text { use in FY97, if possible, after } \\
\text { Secretarial Determination }\end{array}$ & $\begin{array}{l}\text { March 12, 1997; } \\
\text { sales authorized } \\
\text { for FY97 }\end{array}$ & None & $\begin{array}{l}\text { LEU expected to be sold or } \\
\text { transferred to USEC in lleu } \\
\text { of contractual obligations }\end{array}$ \\
\hline $\begin{array}{l}\text { Sell } \\
\text { Russlan } \\
\text { HEU Feed } \\
\text { Transferred } \\
\text { to DOE } \\
\text { from USEC } \\
\text { (as UF } \text { ( }_{6}\end{array}$ & 5.5 & $\begin{array}{l}\text { Sell about half to Russia for use in } \\
\text { matched sales to domestic end } \\
\text { users (only } 1.0 \text { TMTU of matched } \\
\text { sales allowed in calendar 1997). } \\
\text { Sell remaining material for } \\
\text { overfeeding, foreign end use, or in } \\
2001 \text { for domestic end use after } \\
2002\end{array}$ & Not required & $\begin{array}{l}\text { DOE and Global Nuclear } \\
\text { Services and Supply (GNSS) } \\
\text { signed contract on December } \\
\text { 12, 1996; DOE to provide } \\
\text { GNSS with uranium for use in } \\
\text { matched sales. First delivery } \\
\text { made to GNSS on December } \\
30,1996\end{array}$ & \\
\hline $\begin{array}{l}\text { Transfer } \\
\text { DOE } \\
\text { Surplus } \\
\text { Natural } \\
\text { Uranium to } \\
\text { USEC' (as }^{\prime} \text { UF }_{6} \text { ) }\end{array}$ & Up to 7.0 & Pending & Not required & None & $\begin{array}{l}\text { - Transfer to Include } 50 \\
\text { metric tons HEU; total } \\
\text { UF } F_{8} \text { and HEU } \\
\text { equivalent to } 12.0 \\
\text { TMTU } \\
\text { - USEC not permitted to } \\
\text { sell transferred } \\
\text { material until January } \\
1,1998 \text {, only at a rate } \\
\text { of } 10 \text { percent per year } \\
\text { not exceeding } 1.5 \\
\text { TMTU (including HEU) }\end{array}$ \\
\hline
\end{tabular}

"The Secretary of Energy must determine that the sale of material will not have an adverse material impact on the domestic uranlum mining, conversion, and enrichment industry pursuant to USEC Privatization Act (April 26, 1996), Section 3112 (d).

${ }^{b} \mathrm{~F}_{6}$ is the chemical formula for uranium hexafluoride; it is used as feedstock for producing LEU.

'FY97: Fiscal Year 1997-October 1, 1996 to September 30, 1997.

'Natural uranlum component of LEU derived from Russian HEU, transferred from the U.S. Enrichment Corporation (USEC) to the DOE pursuant to USEC Privatization Act (April 26, 1996), Section 3112 (b).

-Sales of Russian uranlum to U.S. end users must be matched with newly produced U.S.-origin uranium pursuant to the Amendment to the Suspension Agreement with the Russian Federation (March 11, 1994).

'DOE is directed to transfer to the U.S. Enrichment Corporation (USEC) without cost up to 7,000 metric tons of natural uranium and 50 metric tons of EU pursuant to the USEC Privatization Act (April 26, 1996), Section 3112(c).

Sources: Sales of natural uranium and LEU-U.S. Department of Energy, Office of Nuclear Energy, Science and Technology, Environmental Assessment DOE Sale of Surplus Natural and Low Enriched Uranium, DOE/EIA-1172 (Washington, DC, October 1996); George, R.M., "Status Report on DOE's Surplus Uranium Sales Program," speech presented at the Nuclear Energy Institute's Nuclear Fuel Supply Fonum (Washington, DC, January 28, 1997); U.S. Department of Energy, Determination Pursuant to the United States Enrichment Corporation Privatization Act for the Sale of Excess Department of Energy Uranium During Fiscal Year 1997 (Washington, DC, March 12, 1997); Transfer of natural uranium to USEC-U.S. Department of Energy Office of Fissile Materials Disposition, Disposition of Surplus Highly Enriched Uranium Final Environmental Impact Statement, DOE/EIS-0240-D (Washington, DC, June 1996); R. George, personal communication (Office of Nuclear Energy, Science and Technology, Germantown, MD, September 30,1997$)$. 
Table E4. Potential Commercial Availability of U.S. and Russian Surplus Defense Inventories, 1997-2010, Based on Schedules Contained in Government Disposition Plans as of March 31, 1997

\begin{tabular}{|c|c|c|c|c|c|c|c|c|c|c|c|c|c|c|c|}
\hline $\begin{array}{c}\text { Thousand Metric Tons } \\
\text { Equivalent }\end{array}$ & 1997 & 1998 & 1999 & 2000 & 2001 & 2002 & 2003 & 2004 & 2005 & 2006 & 2007 & 2008 & 2009 & 2010 & Total \\
\hline Russian HEU ${ }^{a}$ & 5.5 & 7.3 & 9.2 & 9.2 & 9.2 & 9.2 & 9.2 & 9.2 & 9.2 & 9.2 & 9.2 & 9.2 & 9.2 & 9.2 & 123.2 \\
\hline Total Russian HEU Feed . . . . . . . . & 6.6 & 8.7 & 9.5 & 9.2 & 9.2 & 10.3 & 10.3 & 9.7 & 9.2 & 9.2 & 9.2 & 9.2 & 9.2 & 9.2 & 128.7 \\
\hline U.S. HEU 40MT "Off-spec" ${ }^{\text {a }} \ldots$. . & 0.0 & 0.0 & 0.0 & 0.0 & 0.6 & 0.6 & 0.6 & 0.6 & 0.6 & 0.6 & 0.6 & 0.6 & 0.6 & 0.6 & 5.8 \\
\hline Total US HEU Feed & 1.2 & 1.7 & 0.5 & 0.5 & 1.1 & 1.1 & 1.1 & 1.1 & 1.1 & 1.1 & 1.1 & 0.6 & 0.6 & 0.6 & 13.2 \\
\hline U.S. Natural U Transfer ${ }^{\prime}$. . & 0.0 & 0.8 & 0.7 & 0.7 & 0.7 & 0.7 & 0.7 & 0.7 & 0.7 & 0.7 & 0.7 & 0.0 & 0.0 & 0.0 & 7.0 \\
\hline Total Government Inventories & 9.0 & 12.4 & 11.9 & 11.6 & 12.1 & 13.3 & 13.3 & 11.4 & 11.0 & 11.0 & 11.0 & 9.8 & 9.8 & 9.8 & 157.2 \\
\hline
\end{tabular}

Assumptions: a. As of June 30,1997, the Russia Executive Agent had not sold any of the uranium feed component returned to it by USEC. Assuming that sales had begun later in 1997, approximately 50 percent of the uranium feed contained in LEU derived from blending down 18 metric tons of HEU (Russian feed) will be sold in the market during 1997. In subsequent years, it is assumed that 100 percent of Russian feed returned to the Russian Executive Agent will be sold in the market. The quantity of Russian feed corresponds to the schedule for blending down HEU from 1998 through 2001 established by the amendment to the Russian HEU Agreement, signed in November 1996. For 2002 and later years, it is assumed that 30 metric tons of $\mathrm{HEU}$ will be blended down each year. The uranium content is equivalent to the feed contained in LEU assaying at 4.4 percent ${ }^{235} \mathrm{U}$. The LEU is to be derived from HEU and blendstock, with ${ }^{235} \mathrm{U}$ assays of 90 percent and 1.5 percent, respectively

b. Russian feed derived from LEU purchased by USEC in 1995 and 1996 . The sale of this uranium is regulated by the USEC Privatization Act. All EIA cases contain the assumption that 7.0 million pounds of $\mathrm{U}_{3} \mathrm{O}_{8}$ will be sold through matched sales contracts, the annual quantity limited by quotas provided for by the Suspension Agreement between the United States and Russia. The remaining 7.2 million pounds $\mathrm{U}_{3} \mathrm{O}_{8}$ will be sold by DOE beginning in 2002 .

c. USEC plans to add this HEU to its production stream during 1997-1999. Uranium assumed to be made available to the market in the year that the corresponding quantity of HEU is blended down into LEU assaying at 4.95 percent ${ }^{235} \mathrm{U}$. The LEU is to be derived from HEU and LEU blendstock, with ${ }^{235} \mathrm{U}$ assays of 75.7 percent and 2.0 percent, respectively. However, only the uranium contained in the HEU is considered for this analysis because the blendstock would have been sold in the market regardless of the decision to blend down HEU.

d. Schedule pursuant to USEC Privatization Act. HEU is to be blended down to LEU assaying at 4.95 percent ${ }^{235} \mathrm{U}$. The LEU is to be derived from $\mathrm{HEU}$ and natural $U$ blendstock, with average ${ }^{235} \mathrm{U}$ assays of 41.3 percent and 0.71 percent, respectively. However, only the uranium contained in the HEU is considered for this analysis because the blendstock would have been sold in the market regardless of the decision to blend down HEU.

e. Schedule pursuant to DOE's HEU disposition plan, September 1996. HEU is to be blended down to LEU assaying at 4.60 percent ${ }^{235} \mathrm{U}$. The LEU is to be derived from HEU having an average assay of 66.0 percent ${ }^{235} \mathrm{U}$ and depleted uranium blendstock with an average assay of 0.30 percent ${ }^{235} \mathrm{U}$. However, only the uranium contained in the HEU is considered for this analysis because depleted uranium blendstock is currently stored as waste.

f. Schedule pursuant to USEC Privatization Act.

g. DOE is assumed to sell the quantity proposed in the Secretary's Determination, March 1997.

MT=Metric tons.

Sources: Uranium contained in Russian HEU feed and transfer of natural uranium-Energy Resources International, Inc., "1997 Nuclear Fuel Cycle Supply and Price Report," (Washington, DC, May 1997); uranium contained in U.S. HEU feed-R. Schmidt, personal correspondence, (HEU Disposition Program Office, Oak Ridge, TN, September 24, 1997); uranium contained in proposed sales of LEU and natural uranium by DOE-U.S. Department of Energy, Office of Nuclear Energy, Science and Technology, Environmental Assessment DOE Sale of Surplus Natural and Low Enriched Uranium, DOEJEA-1172 (Washington, DC, October 1996). 
Table E5. Assumed Market Penetration of U.S. and Russian Surplus Defense Inventories In the Uranlum Market, 1997-2010, Reference Case

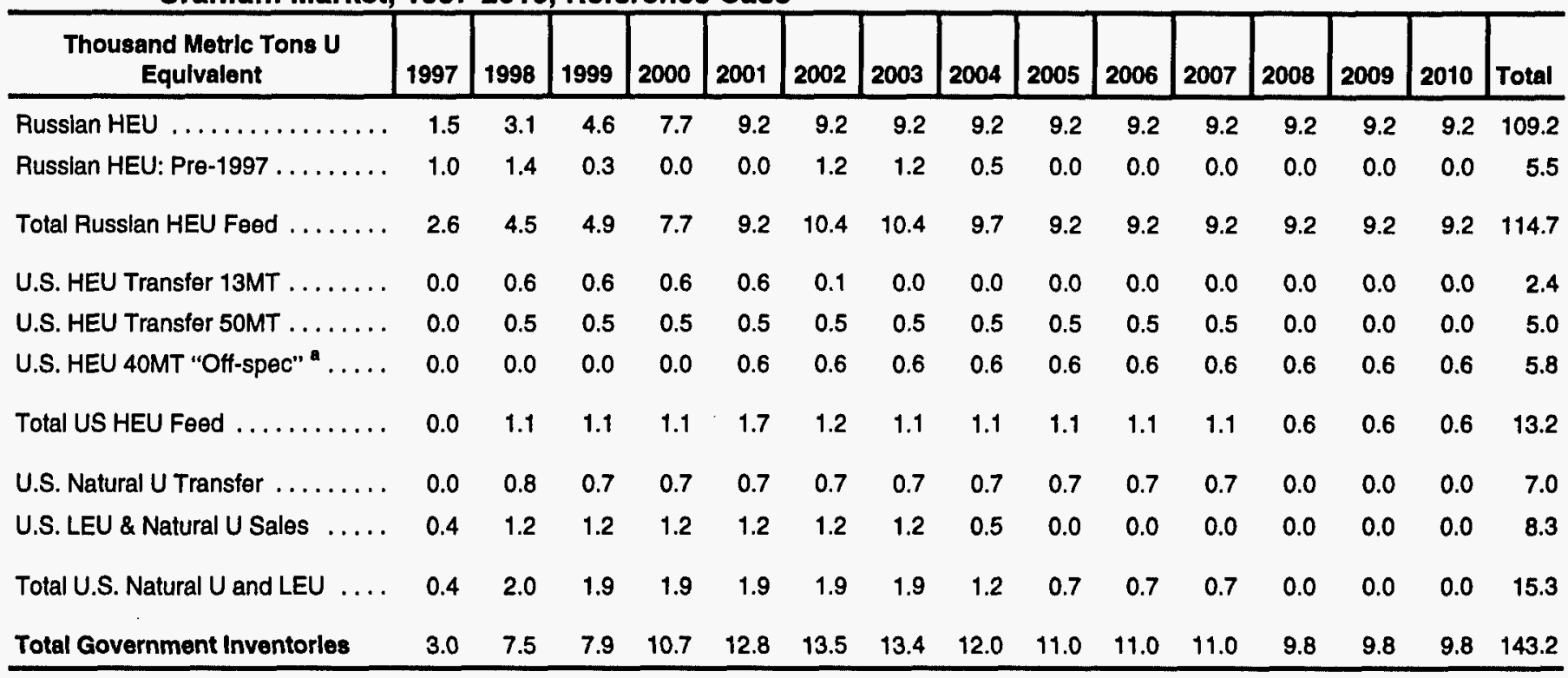

Assumptions: For the Reference Case, EIA assumes that the sales of uranium derived from U.S. and Russlan Government surplus inventorles will be delayed due to programmatic and market conditions. See Table 6-1 for assumptions used in determining the equivalent amount of uranium contained in the inventorles.

"Since the analysis was completed, the U.S. Department of Energy has revised the quantity and timing for the commercialization of "Off-spec" HEU. These changes are anticlpated to have only a marginal impact on projections of supply and spot-market price.

MT=Metric tons.

Sources: Uranium contained in LEU blended down from Russian HEU and transfer of natural uranlum-Energy Resources International, Inc., "1997 Nuclear Fuel Cycle Supply and Price Report," (Washington, DC, May 1997); uranium contained in U.S. HEU feed-R. Schmldt, personal correspondence, (HEU Disposition Program Office, Oak Ridge, TN, September 24, 1997); uranium contalned in proposed sales of LEU and natural uranium by DOE-U.S. Department of Energy, Office of Nuclear Energy, Science and Technology, Environmental Assessment DOE Sale of Surplus Natural and Low Enriched Uranlum, DOE/EA-1172 (Washington, DC, October 1996). 
Table E6. Assumed Market Penetration of U.S. and Russian Surplus Defense Inventories in the Uranlum Market, 1997-2010, Lower HEU Feed Case

\begin{tabular}{|c|c|c|c|c|c|c|c|c|c|c|c|c|c|c|c|}
\hline $\begin{array}{c}\text { Thousand Metric Tons U } \\
\text { Equlvalent }\end{array}$ & 1997 & 1998 & 1999 & 2000 & 2001 & 2002 & 2003 & 2004 & 2005 & 2006 & 2007 & 2008 & 2009 & 2010 & Total \\
\hline Russian HEU & 1.5 & 3.1 & 4.6 & 7.7 & 9.2 & 9.2 & 9.2 & 9.2 & 9.2 & 7.7 & 6.2 & 6.2 & 6.2 & 6.2 & 95.4 \\
\hline Total Russian HEU Feed . & 2.6 & 4.5 & 4.9 & 7.7 & 9.2 & 10.4 & 10.4 & 9.7 & 9.2 & 7.7 & 6.2 & 6.2 & 6.2 & 6.2 & 100.9 \\
\hline U.S. HEU 4OMT "Off-spec" a & 0.0 & 0.0 & 0.0 & 0.0 & 0.6 & 0.6 & 0.6 & 0.6 & 0.6 & 0.6 & 0.6 & 0.6 & 0.6 & 0.6 & 5.8 \\
\hline Total US HEU Feed & 0.0 & 1.1 & 1.1 & 1.1 & 1.7 & 1.2 & 1.1 & 1.1 & 1.1 & 1.1 & 1.1 & 0.6 & 0.6 & 0.6 & 13.2 \\
\hline U.S. Natural U Transfer & 0.0 & 0.8 & 0.7 & 0.7 & 0.7 & 0.7 & 0.7 & 0.7 & 0.7 & 0.7 & 0.7 & 0.0 & 0.0 & 0.0 & 7.0 \\
\hline
\end{tabular}

Assumptions: Russia will take back 3.1 thousand metric tons $U$ of Russlan feed per year for internal use, beginning in 2002. Sales of Russian HEU feed is anticipated to remain at 9.2 thousand metric tons $U$ per year until 2006, due to the availability of Russian HEU feed not sold in previous years. See Table 6-1 for assumptions used in determining the amount of uranium contained in the surplus inventories.

a Since the analysis was completed, the U.S. Department of Energy has revised the quantity and timing for the commercialization of "off-spec" HEU. These changes are anticipated to have only a marginal impact on projections of supply and spot-market price.

MT=Metric tons.

Sources: Uranium contained in LEU blended down from Russian HEU (Russian feed) and transfer of natural uranium-Energy Resources International, Inc., "1997 Nuclear Fuel Cycle Supply and Price Report," (Washington, DC, May 1997); uranium contained in U.S. HEU feed-R. Schmidt, personal correspondence, (HEU Disposition Program Office, Oak Ridge, TN, September 24, 1997); uranium contained in proposed sales of LEU and natural uranium by DOE-U.S. Department of Energy, Office of Nuclear Energy, Science and Technology, Environmental Assessment DOE Sale of Surplus Natural and Low Enriched Uranium, DOE/EA-1172 (Washington, DC, October 1996). 
Table E7. Assumed Market Penetration of U.S. and Russian Surplus Defense Inventories in the Uranium Market, 1997-2010, Upper HEU Feed Case

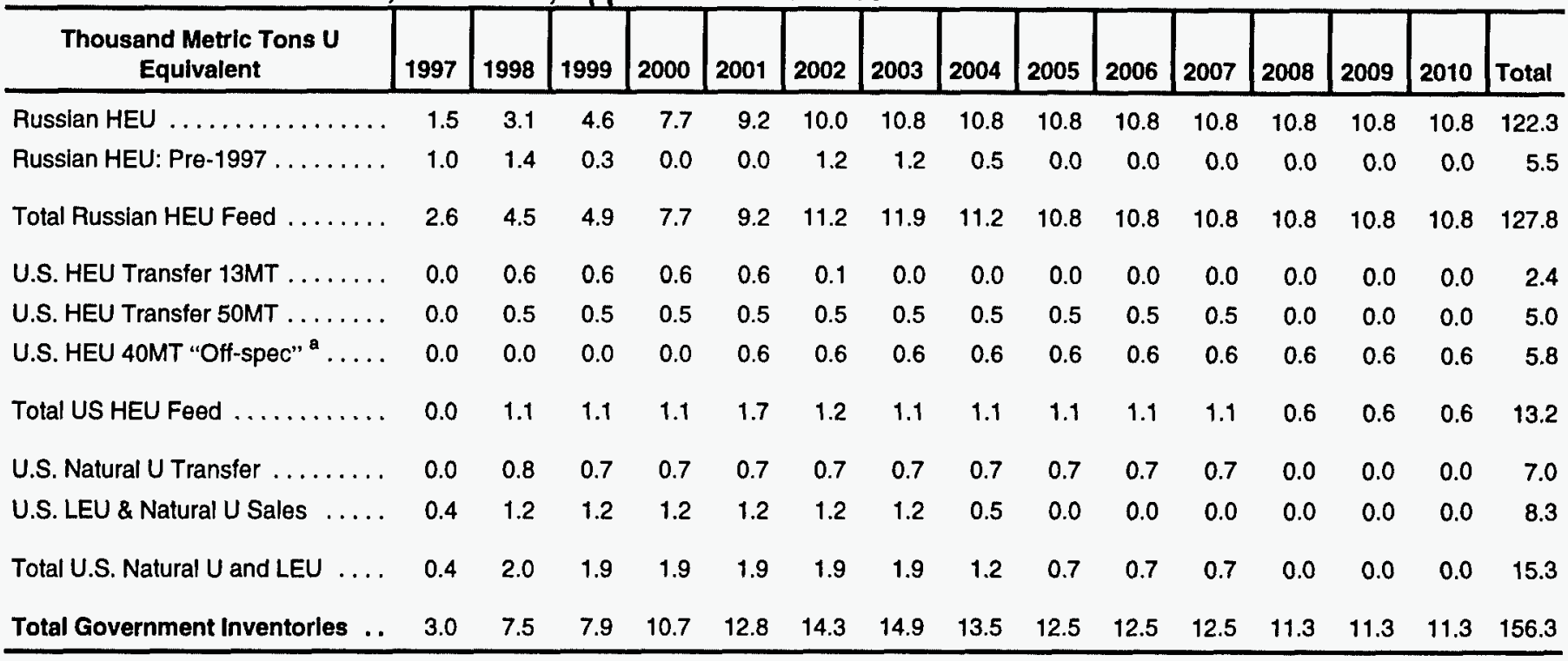

Assumptions: Russian feed will be sold in excess of 9.2 thousand metric tons $U$ equivalent per year, beginning beginning in 2002 . Sales of Russian feed are anticipated to remain at 10.8 thousand metric tons $U$ per year beginning in 2003 . See Table 6-1 for assumptions used in determining the amount of uranium contained in the inventories.

"Since the analysis was completed, the U.S. Department of Energy has revised the quantity and timing for the commerclallzation of "off-spec" $\mathrm{HEU}$. These changes are anticipated to have only a marginal impact on projections of supply and spot-market price.

MT=Metric tons.

Sources: Uranium contained in LEU blended down from Russian HEU (Russian feed) and transfer of natural uranlum-Energy Resources International, Inc., "1997 Nuclear Fuel Cycle Supply and Price Report," (Washington, DC, May 1997); uranium contained in U.S. HEU feed-R. Schmldt, personal correspondence, (HEU Disposition Program Office, Oak Ridge, TN, September 24, 1997); uranium contained in proposed sales of LEU and natural uranium by DOE-U.S. Department of Energy, Office of Nuclear Energy. Science and Technology, Environmental Assessment DOE Sale of Surplus Natural and Low Enriched Uranium, DOE/EA-1172 (Washington, DC, October 1996).

Table E8. Projected Uranium Requirements for 2000, 2005, and 2010 (Thousand Metric Tons U)

\begin{tabular}{c|c|c|c}
\hline Year & $\begin{array}{c}\text { Total } \\
\text { World }\end{array}$ & $\begin{array}{c}\text { Western } \\
\text { World }\end{array}$ & $\begin{array}{c}\text { Western } \\
\text { World With } \\
\text { MOX Use }\end{array}$ \\
\hline $2000 \ldots$ & 61.0 & 53.6 & 51.7 \\
$2005 \ldots \ldots$ & 63.7 & 55.1 & 52.4 \\
$2010 \ldots$. & 63.4 & 54.4 & 51.3 \\
\hline
\end{tabular}

MOX=mixed oxide fuel.

Note: Western World does not include China or the Commonwealth of Independent States.

Sources: Total and Western World uranium requirements-Energy Information Administration, International Nuclear Model PC Version (PCINM), "Reference Case 1997;" MOX use-The Uranium Institute, The Global Nuclear Fuel Market: Supply and Demand 1995-2015, 1996, Table 8.3. 
Table E9. Projected Supply for Western Reactor Requirements for Lower HEU Feed Case, 2000, 2005, and 2010 (Thousand Metric Tons U Equivalent)

\begin{tabular}{|c|c|c|c|}
\hline & 2000 & 2005 & 2010 \\
\hline Western Production . . & 31.6 & 36.7 & 39.5 \\
\hline Australia $\ldots . . . \ldots$. & 8.6 & 10.1 & 10.8 \\
\hline Canada .... & 13.5 & 16.2 & 16.2 \\
\hline Central Africa $^{a}$ & 1.5 & 0.8 & 0.8 \\
\hline Namibia ...... & 2.7 & 3.8 & 3.8 \\
\hline South Africa ... & 1.2 & 1.2 & 1.6 \\
\hline United States & 2.9 & 3.2 & 4.2 \\
\hline Other $^{b} \ldots$ & 1.2 & 1.4 & 2.0 \\
\hline CIS Production . . . . . . & 4.6 & 4.6 & 5.1 \\
\hline China Production .... & 0.6 & $0.0^{c}$ & 0.0 \\
\hline \multicolumn{4}{|l|}{ Surplus Defense } \\
\hline Inventories ... & 10.8 & 11.1 & 6.7 \\
\hline Russian HEU $\ldots \ldots$. & 7.7 & 9.2 & $6.2^{d}$ \\
\hline U.S. HEU, LEU, and U & 3.1 & 1.9 & 0.6 \\
\hline \multicolumn{4}{|l|}{ Commercial } \\
\hline Inventories & 4.1 & $0.0^{c}$ & 0.0 \\
\hline Total Supply & 51.7 & 52.4 & 51.3 \\
\hline
\end{tabular}

aHigher cost production supported by contract commitments from France.

'Includes production centers in Western Europe, Latin America, India, Mongolia, and Pakistan.

${ }^{\circ} \mathrm{China}$ is expected to utilize production for domestic reactor requirements.

dRussia is assumed to take back for internal uses onethird of the equivalent 24 million pounds $\mathrm{U}_{3} \mathrm{O}_{8}$ feed contained in the LEU produced from Russian HEU (Russian HEU feed).

In 2005, 24 million pounds $\mathrm{U}_{3} \mathrm{O}_{8}$ equivalent of Russian HEU feed are assumed to be sold from inventories held by Western commercial firms. In this paper, however, sales of Russian HEU are counted under surplus defense inventories.

CIS=Commonwealth of Independent States.

Note: Totals may not equal sum of components because of independent rounding.

Source: Energy Information Administration, Uranium Market Model Run 1997_60, July 1997. 
Figure E1. Potential Availablity of Uranium Feed from the Blending Down of Russian Highly Enrlched Uranium to Low-Enriched Uranlum During 1997-2010

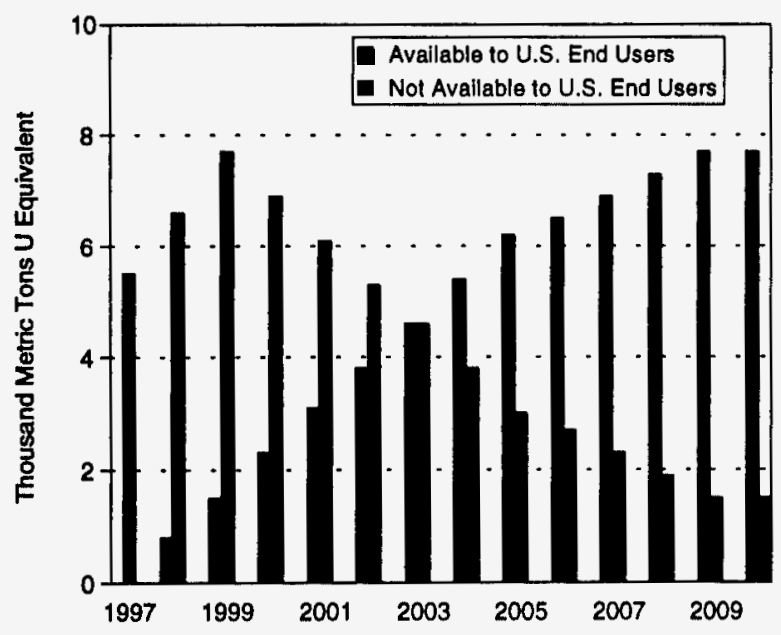

Assumptions: (1) availability to U.S. end users based on direct quota authorized by the USEC Privatization $A c t,(2)$ annual quantity of uranium feed reflects likely capacity for blending down Russian HEU to LEU, the quantity for 1997-2001 was determined by an agreement between the United States Enrichment Corporation (USEC) and Techsnabexport, November 1996; (3) for 2002 and later years, it is assumed that 30 metric tons of Russian HEU will be blended down to LEU per year; and (4) does not consider uranium feed contained in the LEU derived from 18 metric tons of Russian HEU that was purchased by USEC in 1995 and 1996.

Source: U.S. quota-USEC Privatization Act (April 26, 1996), Section 3112 (b).

\section{Figure E2. Projected Spot-Market Prices for the Restrlcted U.S. Uranlum Market, 1997-2010}

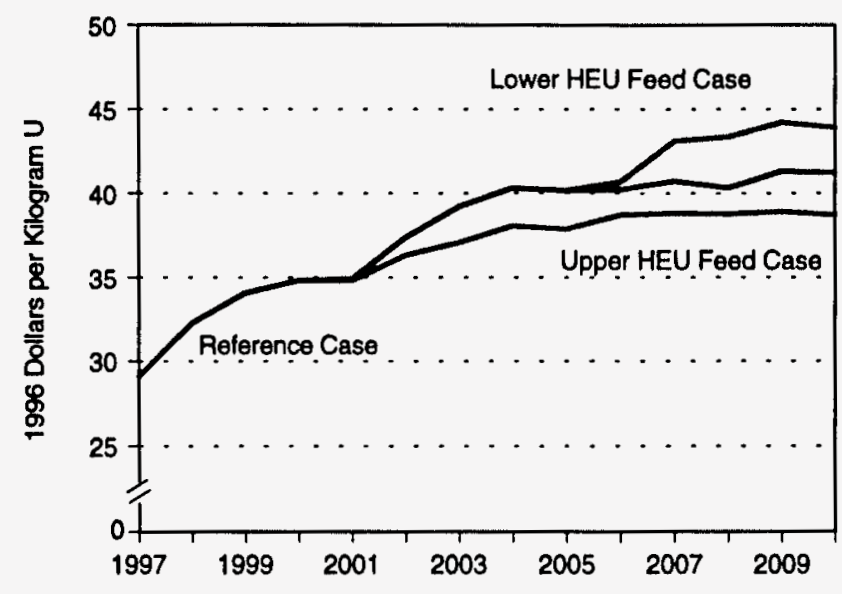

Note: A two-tiered market was developed at the end of 1992 as a result of the suspension agreements that restrict U.S. imports from the Commonwealth of Independent States.

Source: Energy Information Administration, Uranium Market Model runs 1997_60, 1997_73, and 1997_82 (July 1997). 


\section{Glossary}

Assembly: An array of rods containing uranium or MOX fuel that is loaded into the core of a nuclear power reactor. The core of a typical light water reactor would contain around 300 fuel assemblies.

Blendstock: Material used to dilute the concentration of fissile materials (principally ${ }^{235} \mathrm{U}$ or ${ }^{239} \mathrm{Pu}$ ) when blended with a feedstock containing relatively high concentrations of fissile materials. Also referred to as diluent.

Burnup: A measure of the amount of energy obtained from fuel in a reactor. Typically, burnup is expressed as the amount of energy produced per unit weight of fuel irradiated or "burned." Burnup levels are generally measured in units of megawattdays thermal per metric ton of initial heavy metal (MWDT/MTIHM).

Canadian Deuterium-Uranium Reactor (CANDU): A reactor that uses heavy water or deuterium oxide $\left(\mathrm{D}_{2} \mathrm{O}\right)$, rather than light water $\left(\mathrm{H}_{2} \mathrm{O}\right)$ as the coolant and moderator. Deuterium is an isotope of hydrogen that has a different neutron absorption spectrum from that of ordinary hydrogen. In a deuterium-oxide-moderated reactor, fuel made from natural uranium ${ }^{235} \mathrm{U}$ concentration of natural uranium is 0.71 percent) can sustain a chain reaction.

Capacity: The load for which a generating unit is rated, either by the user or by the manufacturer. In this report, "capacity" refers to the utility's design electrical rating.

Centrifuge Process: The enrichment process whereby the concentration of the ${ }^{235} \mathrm{U}$ isotope contained in natural uranium is increased to a level suitable for use in nuclear power plants (generally 3 to 5 percent) by rapidly spinning cylinders containing the uranium in the form of gaseous uranium hexafluoride $\left(\mathrm{UF}_{6}\right)$. Due to differences in the masses of isotopes, the rapid spinning separates the ${ }^{235} \mathrm{U}$ isotope from ${ }^{238} \mathrm{U}$ the principal isotope contained in natural uranium.

Chain Reaction: The process whereby neutrons released from a fission lead to further fissioning of fertile materials. In civilian nuclear power reactors, the chain reaction is controlled and sustained. To produce a explosion from nuclear weapons, the chain reaction is magnified to produce a sudden and intense release of energy.

Commercial Operation: The phase of reactor operation that begins when power ascension ends and the operating utility formally declares that the nuclear power plant is available for the regular production of electricity. This declaration is usually related to the satisfactory completion of qualification tests on critical components of the unit.

Contract-specified price: The delivery price determined when a contract is signed. It can be a fixed price or a price escalated according to a given formula.

Conversion: The chemical processing of uranium concentrate $\left(\mathrm{U}_{3} \mathrm{O}_{8}\right)$ into uranium hexafluoride $\left(\mathrm{UF}_{6}\right)$. $\mathrm{UF}_{6}$ is used as the feedstock for uranium enrichment, part of the fuel cycle for light-water reactors. In preparing fuel for Canadian deuterium-uranium reactors, $\mathrm{U}_{3} \mathrm{O}_{8}$ is converted to $\mathrm{UO}_{2}$, a form of uranium oxide that can be fabricated directly into fuel without enrichment. Conversion does not change the ${ }^{235} \mathrm{U}$ concentration of natural uranium.

Core: The portion of a nuclear reactor containing fuel elements and usually a moderator.

Criticality: The condition in which a nuclear reaction is just self-sustaining (i.e., the rate at which fissioning remains constant.)

Depleted Uranium: Uranium having a concentration of the ${ }^{235} \mathrm{U}$ isotope less than 0.711 percent (by weight), the concentration for naturally occurring uranium. Depleted uranium is a residual product from the enrichment process (see Enrichment Tails).

Discharged Fuel: Irradiated fuel removed from a reactor during refueling. (See Spent Nuclear Fuel.)

Enriched Uranium Product (EUP): Low-enriched uranium that is bought or sold in the market. A nuclear 
power generating company can purchase EUP directly from suppliers, without having to enter into separate transactions for procuring each component: $\mathrm{U}_{3} \mathrm{O}_{8}$, conversion, and enrichment.

Enrichment Tails: The relatively depleted fissile uranium $\left({ }^{235} \mathrm{U}\right)$ remaining from the uranium enrichment process. The natural uranium "feed" that enters the enrichment process generally contains 0.711 percent (by weight) U-235. The "product stream" contains enriched uranium (greater than 0.711 percent ${ }^{235} \mathrm{U}$ ) and the "waste" or "tails" stream contains depleted uranium (less than 0.711 percent ${ }^{235} \mathrm{U}$ ). At the historical enrichment tails assay of 0.2 percent, the waste stream would contain 0.2 percent ${ }^{235} \mathrm{U}$. A higher enrichment tails assay requires more uranium feed (thus permitting natural uranium stockpiles to be decreased), while increasing the output of enriched material for the same energy expenditure.

Fabricated Fuel: Fuel assemblies composed of an array of fuel rods loaded with (1) uranium dioxide pellets, manufactured after conversion of enriched uranium hexafluoride to uranium dioxide; or (2) mixed oxide fuel comprised of oxides of plutonium and uranium.

Fast Breeder Reactor: A reactor in which the fission chain reaction is sustained primarily by fast neutrons rather than by thermal or intermediate neutrons. Fast reactors require little or no use of a moderator to slow down the neutrons from the speeds at which they are ejected from the fissioning nuclei. This type of reactor produces more fissile material than it consumes.

Fertile Material: Material that is not itself fissionable by thermal neutrons but can be converted to fissile material by irradiation. The two principal fertile materials are ${ }^{238}$ uranium and ${ }^{232}$ thorium.

Fissile Material: Material that can be caused to undergo atomic fission when bombarded by neutrons. The most important fissionable materials are ${ }^{235}$ uranium and ${ }^{239}$ plutonium.

Fission: The process whereby an atomic nucleus of appropriate type, after capturing a neutron, splits into (generally) two nuclei of lighter elements, with the release of substantial amounts of energy and two or more neutrons.

Forward Coverage: Amount of uranium required to assure uninterrupted operation of nuclear power plants.
Gaseous Diffusion Process: The enrichment process whereby the concentration of the ${ }^{235} \mathrm{U}$ isotope contained in natural uranium is increased to a level suitable for use in nuclear power plants (generally 3 to 5 percent) by passing the uranium in the form of gaseous uranium hexafluoride $\left(\mathrm{UF}_{6}\right)$ through a series of porous membranes. In the process, the lighter ${ }^{235} \mathrm{U}$ isotope passes more easily through the membranes than does the heavier ${ }^{238} \mathrm{U}$ the principal isotope contained in natural uranium, resulting in progressively higher concentrations of ${ }^{235} \mathrm{U}$.

Generation (Electricity): The process of producing electric energy from other forms of energy.

Geologic Repository: A facility that has an excavated subsurface system for the permanent disposal of spent fuel and high-level waste.

Graphite-Moderated Reactor: A reactor that uses graphite as its moderator (see moderator).

Heavy Water: Water containing a significantly greater proportion of heavy hydrogen (deuterium) atoms to ordinary hydrogen atoms than is found in ordinary (light) water. Heavy water is used as a moderator in some reactors because it slows neutrons effectively and also has a low cross-section for absorption of neutrons.

High-level Waste: As defined by the Nuclear Waste Policy Act of 1988, the highly radioactive material resulting from the reprocessing of spent nuclear fuel or other highly radioactive material that the U.S. Nuclear Energy Commission, consistent with existing law, determines by rule to require permanent isolation.

Highly Enriched Uranium (HEU): Uranium enriched to at least 20 percent ${ }^{235} \mathrm{U}$ (by weight). HEU is used primarily for national security purposes, principally for the producing nuclear weapons and fuel for reactors to propel naval submarines and other vessels. Weaponsgrade HEU contains at least 90 percent ${ }^{235} \mathrm{U}$.

Interim Storage Site: A site where spent nuclear fuel or other nuclear wastes are temporarily stored pending transfer to a geologic repository or other permanent disposal site. Interim storage sites for civilian spent fuel are storage pools or dry cask storage facilities, usually located at the reactor sites, licensed by (or proposed to be licensed by) the Nuclear Regulatory Commission. 
Irradiated Nuclear Fuel: Nuclear fuel that has been exposed to radiation in the reactor core at any power level.

Light Water: Ordinary water $\left(\mathrm{H}_{2} \mathrm{O}\right)$, as distinguished from heavy water or deuterium oxide $\left(D_{2} O\right)$.

Light-Water Reactor (LWR): A nuclear reactor that uses water as the primary coolant and moderator, with slightly enriched uranium as fuel. There are two types of commercial light-water reactors-the boiling-water reactor (BWR) and the pressurized-water reactor (PWR).

Long-Term Contract Price: Delivery price determined when contract is signed; it can be either a fixed price or a base price escalated according to a given formula.

Low-Enriched Uranium (LEU): Uranium enriched in the isotope ${ }^{235} \mathrm{U}$, from 0.711 percent (by weight) in natural uranium up to 19 percent. LEU is used in this report to indicate enrichment between 3 and 5 percent ${ }^{235} \mathrm{U}$, the average required for fueling commercial lightwater reactors.

Low-level Waste: As specified in the Low-level Radioactive Waste Policy Amendments Act of 1985 (Public Law 99-240), radioactive waste not classified as highlevel waste, spent nuclear fuel, or by-product material specified as uranium or thorium tailings or waste.

Marginal Cost: The cost to the producer of providing the next (marginal) increment of uranium, conversion, enrichment, or fabricated fuel, irrespective of sunk costs.

Market-price Contract: A contract in which the price of uranium is not specifically determined at the time the contract is signed but based instead on the prevailing market price at the time of delivery. A market-price contract may include a floor price, that is, a lower limit on the eventual settled price. The floor price and the method of price escalation generally are determined when the contract is signed. The contract may also include a price ceiling or a discount from the agreedupon market price reference.

Matched Sales: A legal procedure whereby specified quantities of natural uranium or enriched uranium product could be imported from Russia for end use in the United States as long as they are matched with equal quantities of newly produced U.S.-origin uranium. Matched sales are the result of an agreement between the United States and the Russian Federation.
Megawatthour (Mwh): One million watts of electric energy.

Megawattday (Mwd): Twenty-four Mwh's or 24 million watthours of electric energy.

Metric Ton: One thousand kilograms or 1.1 short tons (2,205 pounds).

Metric Tons of Initial Heavy Metal (MTIHM): The weight of the initial fuel loading (in metric tons) used in an assembly.

Mixed Oxide (MOX) Fuel: A fuel fabricated from oxides of plutonium and uranium. Typically, MOX fuel contains up to 5 percent fissile plutonium, with the remainder consisting of depleted or natural uranium.

Moderator: A material such as ordinary water, heavy water, or graphite, used in a reactor to slow down highvelocity neutrons, thus increasing the likelihood of further fission.

Natural Uranium: Uranium with the ${ }^{235} \mathrm{U}$ isotope present at a concentration of 0.711 percent (by weight), that is, uranium with its isotopic content exactly as it is found in nature.

Nuclear Power Plant: A single- or multi-unit facility in which heat produced in a reactor by the fissioning of nuclear fuel is used to drive a steam turbine(s).

Nuclear Reactor: An apparatus in which the nuclear fission chain can be initiated, maintained, and controlled so that energy is released at a specific rate. The reactor apparatus includes fissionable material (fuel) such as uranium or plutonium; fertile material; moderating material (unless it is a fast reactor); a heavy-walled pressure vessel; shielding to protect personnel; provision for heat removal; and control elements and instrumentation.

Nuclear Weapons: Atomic or hydrogen weapons that could produce a nuclear explosion.

Plutonium (Pu): A heavy, fissionable, radioactive, metallic element (atomic number 94). Plutonium is produced as a byproduct of the fission reaction in a uranium-fueled nuclear reactor and has been recovered from irradiated fuel. It is used in preparing commercial nuclear fuel and in manufacturing nuclear weapons. 
Plutonium-Production Reactor: Reactor designed specifically to produce weapons-grade plutonium by neutron irradiation of the uranium isotope ${ }^{238} \mathrm{U}$.

Power Ascension: The period of time between a plant's initial fuel loading date and its date of first commercial operation (including the low-power testing period). Plants in the first operating cycle (the time from initial fuel loading to the first refueling), which lasts approximately 2 years, operate at an average capacity factor of about 40 percent.

Pressurized-Water Reactor (PWR): A nuclear reactor in which heat is transferred from the core to a heat exchanger via water kept under high pressure, so that high temperatures can be maintained in the primary system without boiling the water. Steam is generated in a secondary circuit.

Production Center: A conventional mill or processing plant which produces uranium concentrate $\left(\mathrm{U}_{3} \mathrm{O}_{8}\right)$ from ores fed from one or more tributary mines and reserves.

Reprocessing: The process by which uranium and plutonium are chemically separated from spent fuel. Reprocessed uranium and plutonium have been recycled for civilian and national security purposes.

Safeguards: Procedures put in place to verify that nuclear materials have not been diverted for unauthorized uses that could lead to the proliferation of nuclear weapons.

Separative Work Unit (SWU): The standard measure of enrichment services. The effort expended in separating a mass $F$ of feed of assay $x_{F}$ into a mass $P$ of product of assay $x_{P}$ and waste of mass $W$ and assay $x_{W}$ is expressed in terms of the number of separative work units needed, given by the expression $S W U=W V\left(x_{w}\right)+P V\left(x_{p}\right)$ $F V\left(x_{F}\right)$, where $V(x)$ is the "value function," defined as $V(x)=(1-2 x) \ln [(1-x) / x]$.

Spent Nuclear Fuel: Irradiated fuel that is permanently discharged from a reactor at the end of a fuel cycle. Spent or irradiated fuel is usually discharged from reactors because of chemical, physical, and nuclear changes that make the fuel no longer efficient for the production of heat, rather than because of the complete depletion of fissionable material. Except for possible reprocessing, this fuel must eventually be removed from its temporary storage location at the reactor site and placed in a permanent repository. Spent nuclear fuel is typically measured either in metric tons of heavy metal (i.e., only the heavy metal content of the spent fuel is considered) or in metric tons of initial heavy metal (essentially, the initial mass of the uranium before irradiation). The difference between these two quantities is the weight of the fission products.

Split Tails: Use of one tails assay for transaction of enrichment services and a different tails assay for operation of the enrichment plant. This mode of operations typically increases the use of uranium, which is relatively inexpensive, while decreasing the use of separative work, which is expensive.

Spot Market: The buying and selling of uranium for immediate or very near-term delivery, typically involving transactions for delivery of up to 500,000 pounds $\mathrm{U}_{3} \mathrm{O}_{8}$ within a year of contract execution.

Spot-Market Price: Price for material being bought and sold on the spot market.

Tritium: A radioactive isotope of the element hydrogen with 2 neutrons and one proton. Common symbols for the isotope are $\mathrm{H}-3$ and $\mathrm{T}$. Tritium is used to produce excess neutrons which would increase fissioning in nuclear weapons.

Unfilled Requirements: Requirements not covered by usage of inventory or supply contracts in existence as of January 1 of a given year.

Uranium (U): A heavy, naturally radioactive, metallic element of atomic number 92. Its two principally occurring isotopes are ${ }^{235} \mathrm{U}$ and ${ }^{238} \mathrm{U} .{ }^{235} \mathrm{U}$ is indispensable to the nuclear industry because it is the only isotope existing in nature to any appreciable extent that is fissionable by thermal neutrons. ${ }^{238} \mathrm{U}$ is also important, because it absorbs neutrons to produce a radioactive isotope that subsequently decays to ${ }^{239} \mathrm{Pu}$, an isotope that also is fissionable by thermal neutrons.

Uranium Concentrate: A yellow or brown powder produced from naturally occurring uranium minerals as a result of milling uranium ores or processing of uranium-bearing solutions. Synonymous with "yellowcake," $\mathrm{U}_{3} \mathrm{O}_{8}$, or uranium oxide.

Uranium Hexafluoride $\left(\mathrm{UF}_{6}\right)$ : A white solid obtained by chemical treatment of $\mathrm{U}_{3} \mathrm{O}_{8}$, which forms a vapor at temperatures above 56 degrees centigrade. $\mathrm{UF}_{6}$ is the form of uranium required for the enrichment process.

Uranium Oxide: A compound $\left(\mathrm{U}_{3} \mathrm{O}_{8}\right)$ of uranium. Also referred to as "yellowcake" or concentrate when in pure form. 
Uranium Reserves: Estimated quantities of uranium in known mineral deposits of such size, grade, and configuration that the uranium could be recovered at or below a specified production cost with currently proven mining and processing technology and under current laws and regulations. Reserves are based on direct radiometric and chemical measurements of drill hole and other types of sampling of the deposits. Mineral grades and thickness, spatial relationships, depths below the surface, mining and reclamation methods, distances to milling facilities, and amenability of ores to processing are considered in the evaluation. The amount of uranium in ore that could be exploited within the forward cost levels are estimated according to conventional engineering practices, utilizing available engineering, geologic, and economic data.

Weapons-grade Fissile Materials: The concentration of fissile materials used in technologically advanced weapons to sustain fast-neutron chain reactions required for nuclear explosions. Weapons-grade HEU contains 90 percent or more of the fissile isotope ${ }^{235} \mathrm{U}$, while weapons-grade plutonium contains more than 93 percent fissile isotopes, principally ${ }^{239} \mathrm{Pu}$. 


\section{M98005497}

|||||||||||||||||||||||||||||||||||||||||||||||||||||||

Report Number (14) DOE/EIA--0619

Publ. Date (11) 199805

Sponsor Code (18) $D O E / M A, X E$
UC Category (19) $U C-950, D O E / E R$

no 1332,15 in foldec

19980706068 


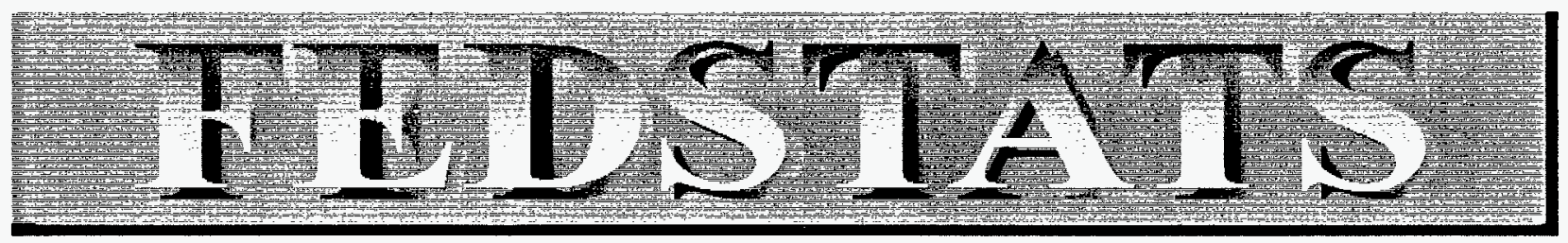

\section{Window on the \\ Spectrum of Federal Statistics}

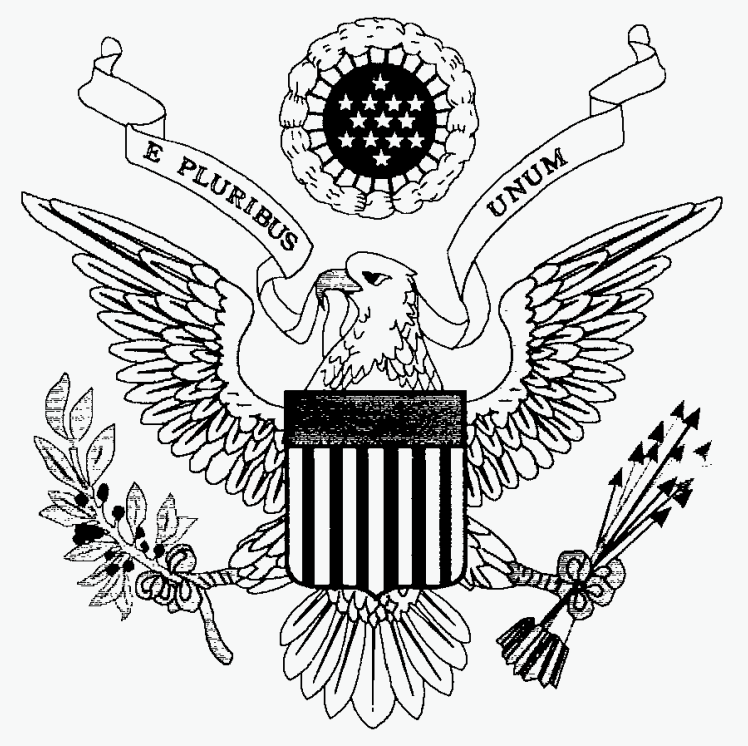

www.fedstats.gov

Easy Access to the Full Range of

Federal Statistics Available for Public Use 